\title{
Biomonitoring of Environmental Status and Trends (BEST) Program: Environmental Contaminants and their Effects on Fish in the Rio Grande Basin
}

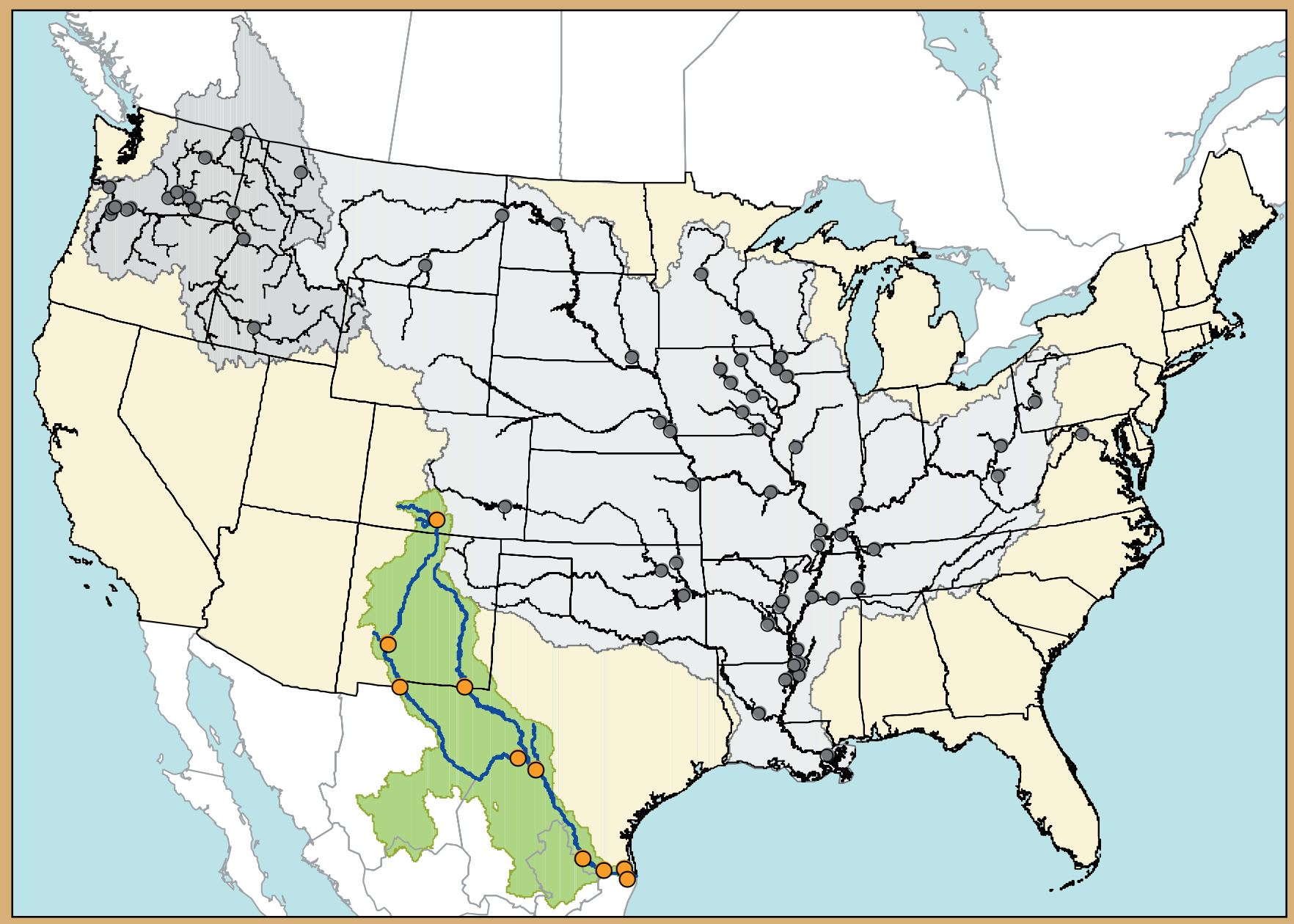

Scientific Investigations Report 2004-5108 
Front cover. The U.S. map shows the Rio Grande Basin (green) and stations sampled in this study (orange). Shown in gray are major river basins and stations in the conterminous U.S. sampled during other Biomonitoring of Environmental Status and Trends Program (BEST) investigations. 


\section{Biomonitoring of Environmental Status and Trends (BEST) Program: Environmental Contaminants and their Effects on Fish in the Rio Grande Basin}

By Christopher J. Schmitt, Gail M. Dethloff, Jo Ellen Hinck, Timothy M. Bartish, Vicki S. Blazer, James J. Coyle, Nancy D. Denslow, and Donald E. Tillitt

Scientific Investigations Report 2004—5108 


\section{U.S. Department of the Interior \\ Gale A. Norton, Secretary \\ U.S. Geological Survey \\ Charles G. Groat, Director}

\section{U.S. Geological Survey, Reston, Virginia: 2004}

For more information about the USGS and its products:

Telephone: 1-888-ASK-USGS

World Wide Web: http://www.usgs.gov/

Any use of trade, product, or firm names in this publication is for descriptive purposes only and does not imply endorsement by the U.S. Government.

Although this report is in the public domain, permission must be secured from the individual copyright owners to reproduce any copyrighted materials contained within this report.

Suggested citation:

Schmitt, C.J., Dethloff, G.M., Hinck, J.E., Bartish, T. M., Blazer, V.S., Coyle, J.J., Denslow, N.D. and Tillitt, D.E., 2004, Biomonitoring of Environmental Status and Trends (BEST) Program: Environmental Contaminants and their Effects on Fish in the Rio Grande Basin: U.S. Geological Survey, Columbia Environmental Research Center, Columbia, Missouri, Scientific Investigations Report 2004—5108, 117 p. 


\section{Preface}

The study described in this report was conducted as part of the Biomonitoring of Environmental Status and Trends (BEST) program of the U.S. Geological Survey (USGS). BEST evolved from two earlier Federal monitoring programs: the National Pesticide Monitoring Program (NPMP) of the 1960s and the National Contaminant Biomonitoring Program (NCBP) of the 1970s and 1980s (Schmitt and Bunck, 1995). The U.S. Fish and Wildlife Service (USFWS) participated in the NPMP and maintained the NCBP by monitoring concentrations of persistent contaminants in freshwater fish and avian wildlife through 1986. BEST was initiated in the 1990s to build on information produced by these earlier programs and to provide more biologically relevant information regarding potential contaminant effects on lands and species under FWS management. The program was transferred to the National Biological Survey in 1993, and ultimately to USGS in 1996; its primary goal is to measure and assess contaminants and their effects on selected U.S. species and habitats. One component of BEST continues to monitor contaminants and their effects on fish in large rivers. The 1997 Rio Grande Basin (RGB) study, which was implemented together with a companion investigation of the Columbia River Basin, was part of this effort. The 1997 investigations represented continuations of a pilot study conducted in the Mississippi River Basin during 1995 (Schmitt, 2002a). Together with ongoing investigations in other basins, these studies comprise an expanded continuation of the NPMP/NCBP freshwater fish monitoring networks; four NCBP stations in the RGB were sampled as part of the 1997 study.

\section{Acknowledgements}

This study was conducted jointly by USGS, through the Columbia Environmental Research Center (CERC) in Columbia, Missouri and the National Fish Health Laboratory of the Leetown Science Center (LSC) in Kearneysville, West Virginia; USFWS, through its Ecological Services Field Offices in Albuquerque, New Mexico and Corpus Christi, Texas; and by cooperating scientists at the University of Florida, Gainesville (UF). Many individuals representing USGS, USFWS, UF, and other organizations contributed substantially during the conduct of the investigation. C. Bunck (USGS) managed the BEST program and S. Finger coordinated most of the work at CERC. M. Wilson (USFWS-Albuquerque) and C. Lee (USFWS-Corpus Christi) supervised field portions of the study. Chemical analyses were conducted at laboratories operated by Mississippi State University and the Research Triangle Institute through contracts managed by the Patuxent Analytical Control Facility (PACF) of the USFWS; J. Moore and P. McDonald of PACF facilitated this part of the study. Laboratory analyses for biomarkers were conducted by D. Nicks and S. Birke (CERC); D. Bowling, K. Spring, and E. Frankenberry (LSC); and M. Chow and K. Kroll (UF). A. Donahue (CERC), J. Smith (USFWS, Albuquerque), D. Buckmeier (Texas Parks and Wildlife, Ingram, Texas) and E. Buckner (Missouri Department of Conservation, Columbia, Missouri) aged the fish. The study was partly funded through a Research Work Order with the USGS-Florida Cooperative Fish and Wildlife Research Unit at UF; F. Percival, Unit Leader, and T. Gross of the USGS FloridaIntegrated Science Center facilitated this agreement. A. Donahue also managed the data and prepared report graphics. P. Anderson assisted with the preparation of the maps and obtained data and information from extant sources. N. Bauch and C. Crawford (USGS-Colorado and Indiana Water Resources District Offices, respectively) obtained and summarized the NASQAN data as part of an ongoing project. B. Wright (Oregon Department of Fish and Game, Corvallis, Oregon) and M. Ellersieck (University of Missouri-Columbia) assisted with statistical analyses. D. Buckler (USGS-CERC), M. Mora (USGS-CERC Field Research Station, Brazos, Texas), J. Whyte (AScI, c/o USGS-CERC), J. Lusk (USFWS-Albuquerque), J. Moring (USGSAustin, Texas) and C. Caldwell (USGS-New Mexico Cooperative Fish and Wildlife Research Unit, New Mexico State University) reviewed all or parts of earlier versions of the report and provided additional information. R. Lipkin (CERC) managed the bibliographic database and prepared the report for publication. 


\section{Contents}

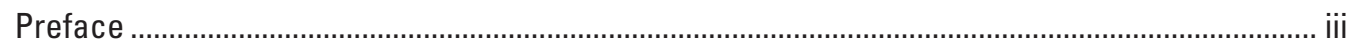

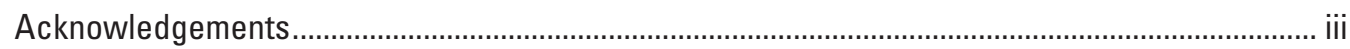

Abstract

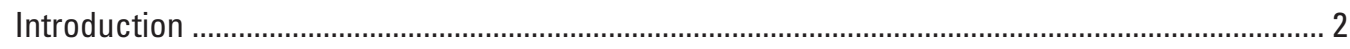

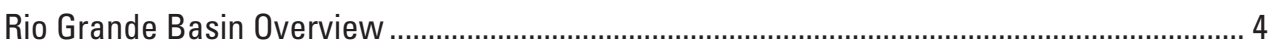

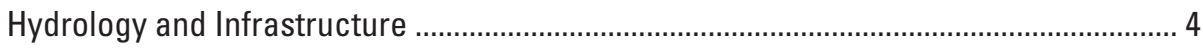

Ecoregions and Climate ........................................................................................ 5

U.S. Dept. of the Interior Resources at Risk from Contaminants in the Rio Grande........ 5

Extant Sources of Information on Contaminants in the RGB ................................................. 6

Major Sources of Contaminants to the Rio Grande ............................................................... 9

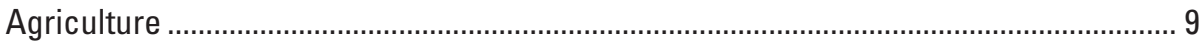

Municipal Wastes ................................................................................................ 10

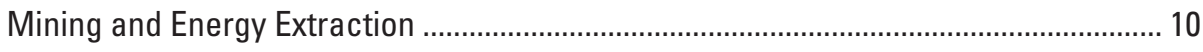

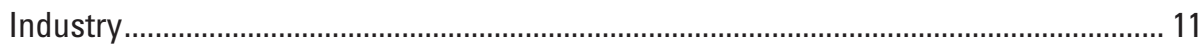

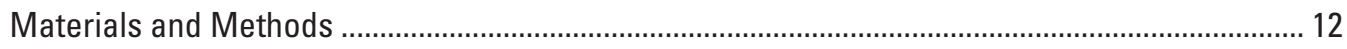

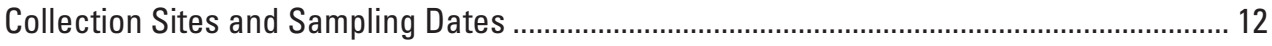

Target Species and Sampling Strategy ........................................................................ 12

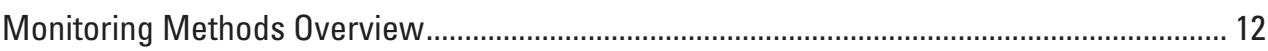

Field Procedures ................................................................................................................ 16

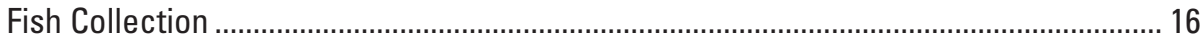

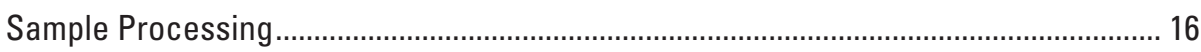

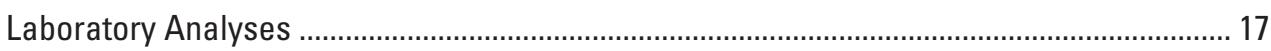

Composite Sample Preparation.............................................................................. 17

Elemental Contaminants and Moisture Content............................................................. 17

Organochlorine Chemical Residues and Lipid Content................................................... 18

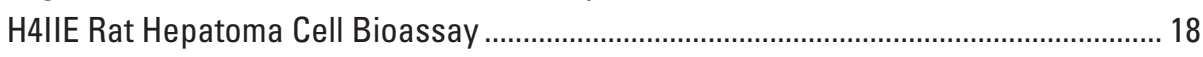

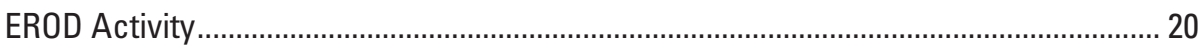

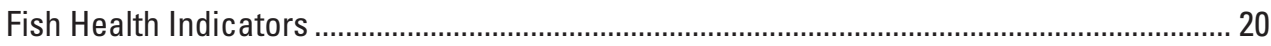

General Histopathological Analyses .......................................................................... 20

Macrophage Aggregates ........................................................................................ 20

Quantitative Organism-Level Indicators ................................................................. 20

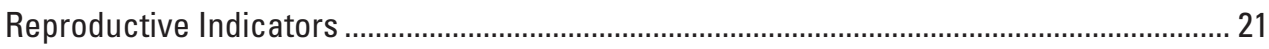

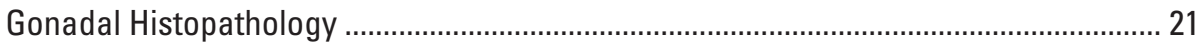

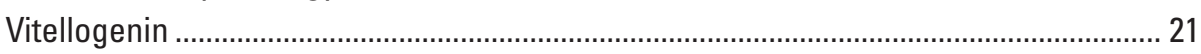

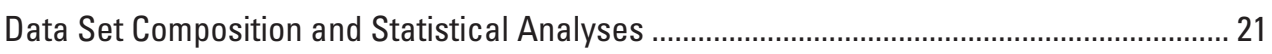

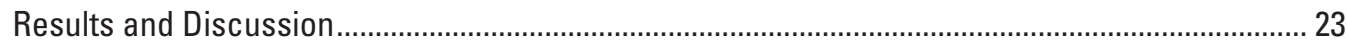

Geographic Distribution and Demographic Characteristics of the Fish Samples ................. 23

Accumulative Contaminants, H4IIE Bioassay, and EROD Activity.......................................... 24

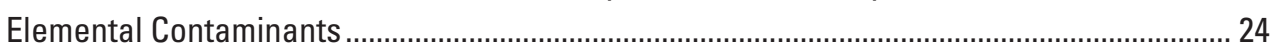

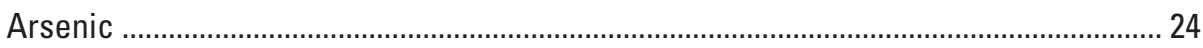

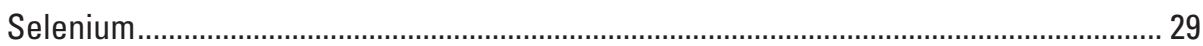

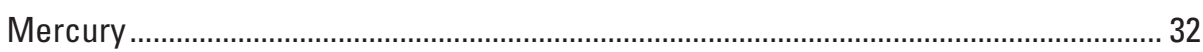

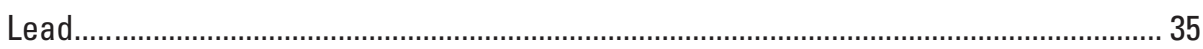

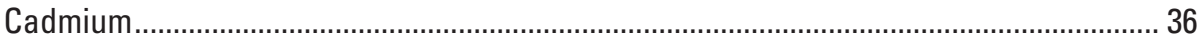

Zinc 
Copper.

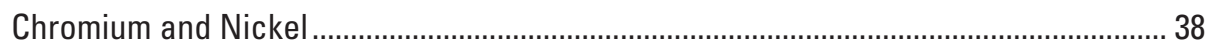

Organochlorine Chemical Residues ……………………................................................ 39

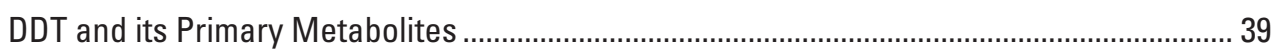

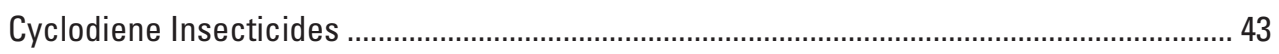

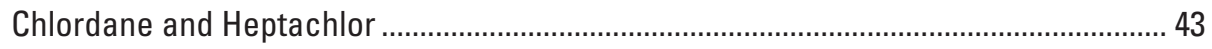

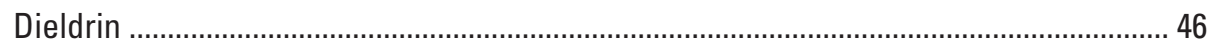

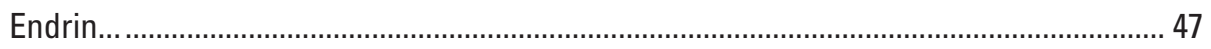

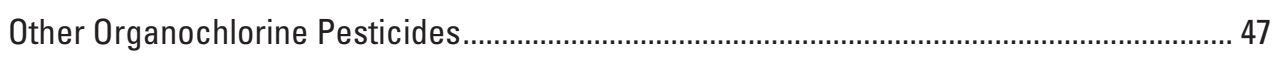

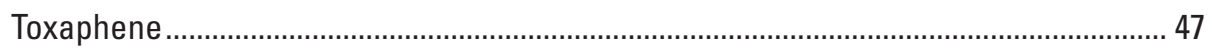

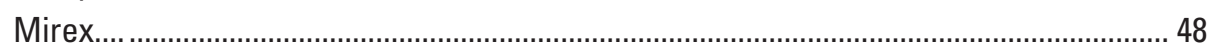

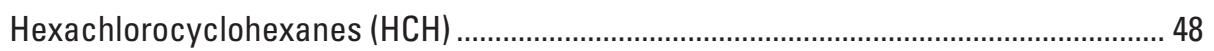

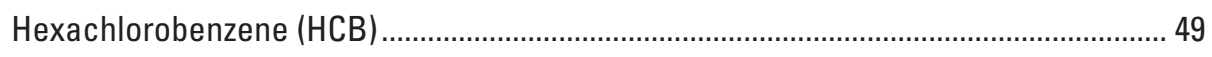

Organochlorine Pesticides not Measured ............................................................... 49

Total PCBs, H4IIE-Derived Dioxin Equivalents, and EROD Activity........................................ 49

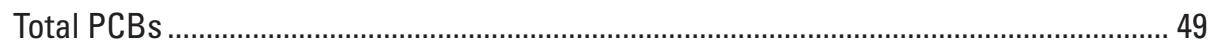

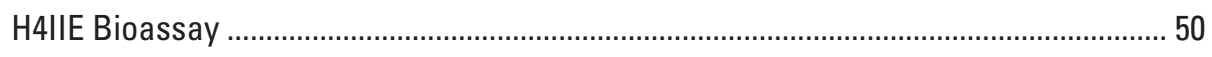

Ethoxyresorufin O-Deethylase (EROD) Activity .......................................................... 50

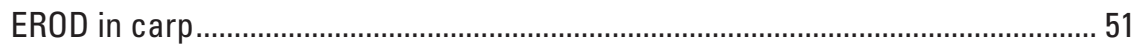

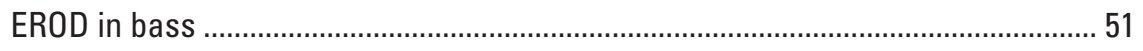

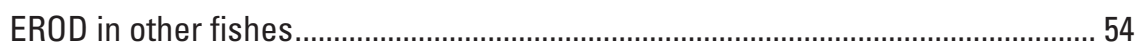

Accumulative Contaminants, H4IIE, and EROD: Summary ……….................................... 55

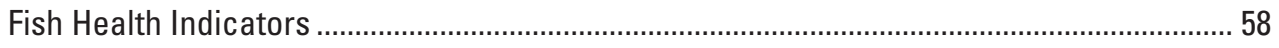

Organism-Level Indic ators ............................................................................ 58

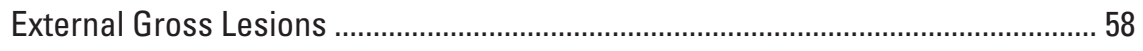

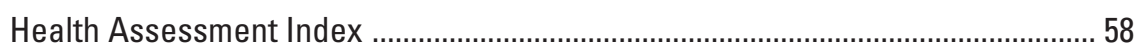

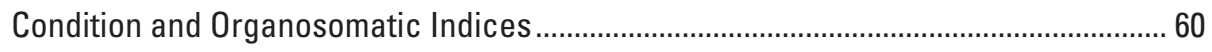

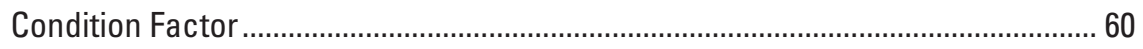

Hepatosomatic Index (HSI) .......................................................................... 60

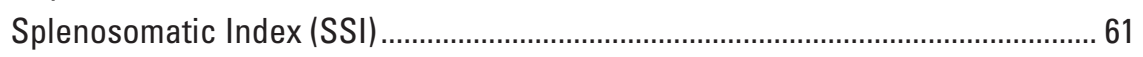

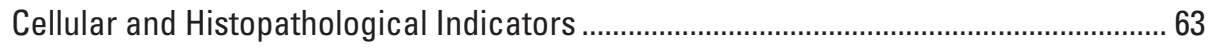

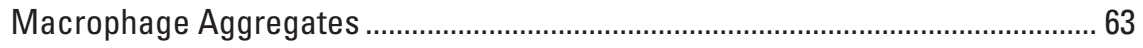

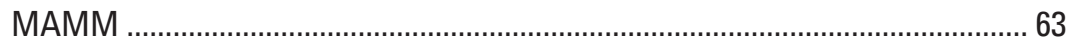

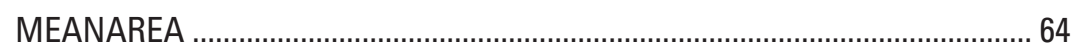

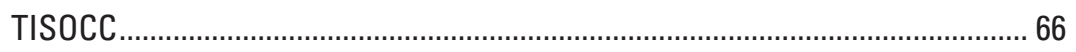

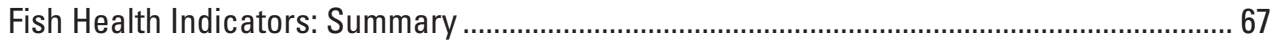

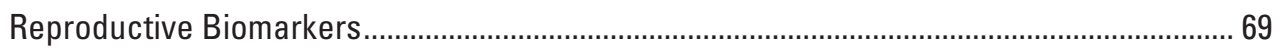

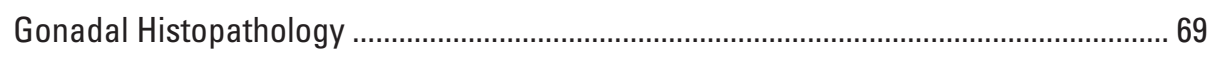

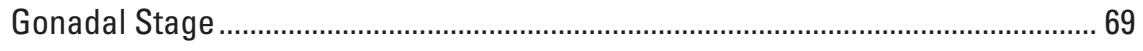

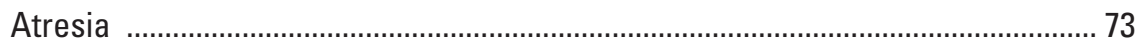

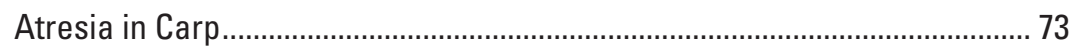

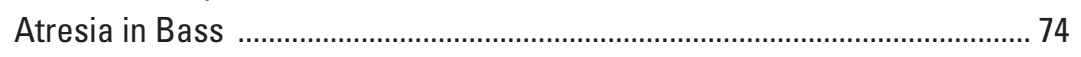

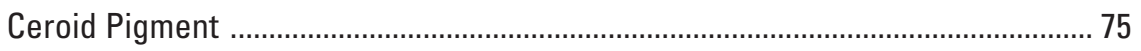

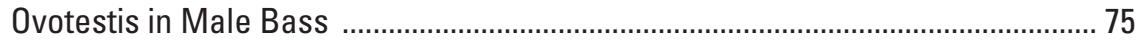

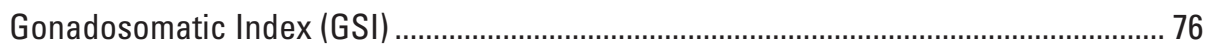

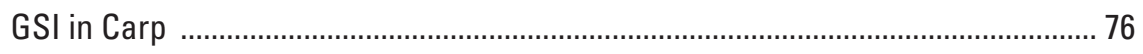

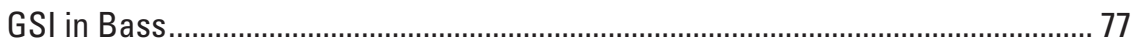

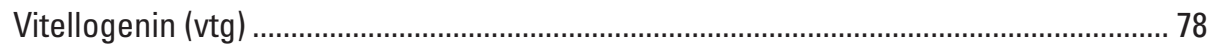




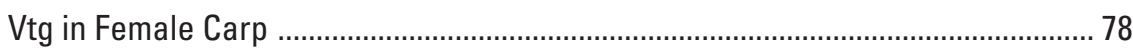

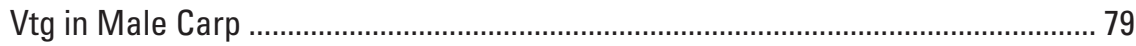

Vtg in Female Bass ......................................................................................... 79

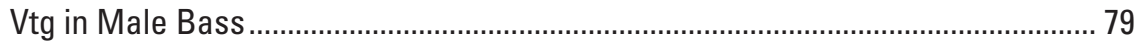

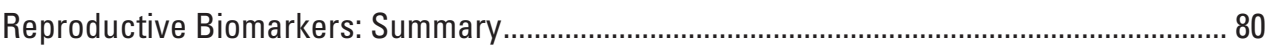

Spatial Patterns in Contaminant Concentrations and Biomarker Responses......................... 81

Upper Rio Grande (Stations 64, 63, and 516) ............................................................ 81

Middle Rio Grande and Pecos River (Stations 65, 515, and 514)................................... 83

Lower Rio Grande and Arroyo Colorado (Stations 16, 511, 512, and 513) ..................... 85

Correlations Between Contaminant Concentrations and Biological Endpoints ............ 86

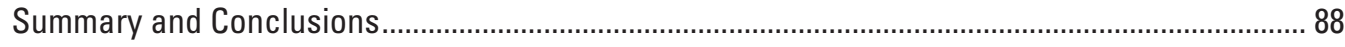

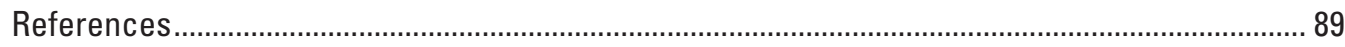

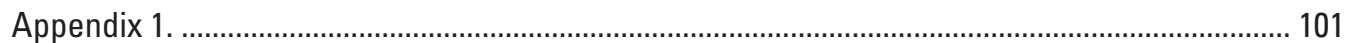

\section{Figures}

1. Map of the Rio Grande Basin illustrating waterways and impoundments, federal and Native American lands and facilities, major metropolitan areas, state boundaries, and locations sampled. ............................................................................................................ 3

2. Concentrations of arsenic (As) and selenium (Se) in composite samples of whole fish ........ 26

3. Concentrations of mercury in composite samples of whole fish ............................................. 32

4. Concentrations of lead $(\mathrm{Pb})$ and cadmium $(\mathrm{Cd})$ in composite samples of whole fish.............. 36

5. Concentrations of zinc $(\mathrm{Zn})$, copper (Cu), chromium ( $\mathrm{Cr})$, and nickel (Ni) in composite

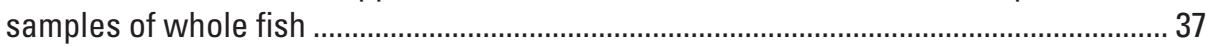

6. Geometric mean concentrations of $p, p^{\prime}-\mathrm{DDT}, \mathrm{DDE}$, and DDD in composite samples of whole

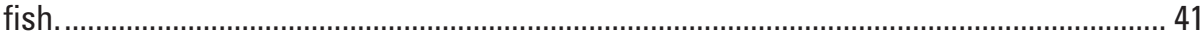

7. Concentrations of $p, p^{\prime}$-DDE, toxaphene, total chlordanes (sum of cis- and trans-chlordanes and nonachlors, heptachlor epoxide, and oxychlordane), and dieldrin in composite samples of whole fish .............................................................................................. 42

8. Geometric mean concentrations of chlordane-related compounds (cis- and trans-chlordanes and nonachlors, heptachlor epoxide, and oxychlordane) in composite samples of whole fish

9. Concentrations of H4IIE bioassay-derived TCDD-EQ in composite samples of whole fish .... 50

10. Hepatic EROD activity in male and female carp and bass (Micropterus sp.)........................... 55

11. Histologic appearance of external gross lesions observed in carp ........................................ 59

12. Health Assessment Index scores of male and female carp and bass (Micropterus sp.)......... 60

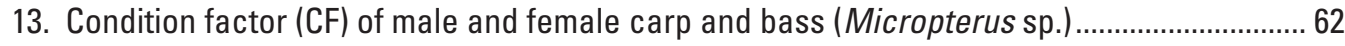

14. Hepatosomatic index (HSI) values of male and female bass (Micropterus sp.) ........................ 62

15. Splenosomatic index (SSI) values of male and female carp and bass (Micropterus sp.)....... 63

16. Splenic macrophage aggregate density (MAMM) in male and female carp and in bass

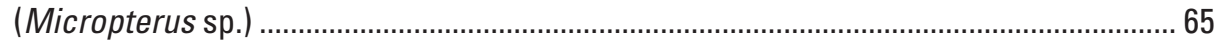

17. Splenic macrophage aggregate area (MEANAREA) in male and female carp and in bass

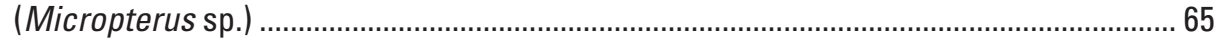

18. Percentage of splenic tissue occupied by macrophage aggregates (TISSOC) in male and

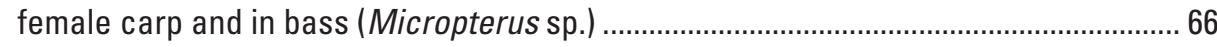

19. Microscopic pathology observed in carp from the Rio Grande Basin. ............................................... 69

20. Thyroid follicles within the kidneys of carp from the Rio Grande Basin. .............................. 70

21. Gonadal stage of male and female carp and bass .............................................................. 71

22. Gonadal stages in female carp and bass ovaries ................................................................ 72

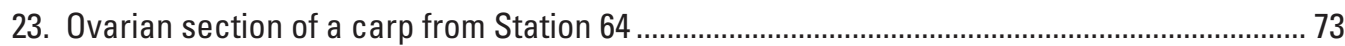


24. Gonadal stages in male carp and bass testes 74

25. Percentage of atretic oocytes in female carp and bass (Micropterus sp.) .............................. 75

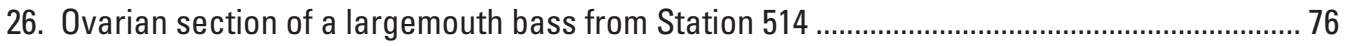

27. Pigmented cell accumulations in the gonads of carp from the Rio Grande Basin ................... 77

28. Gonadosomatic index (GSI) values of male and female carp and bass (Micropterus sp.)..... 78

29. Plasma vitellogenin ( $\mathrm{Vtg}$ ) concentrations in female carp and bass (Micropterus sp.)............ 79

30. Maximum concentrations of total DDT ( $p, p^{\prime}$-homologs), toxaphene, and total chlordanes in composite samples of whole fish.

31. Maximum concentrations of mercury $(\mathrm{Hg})$, arsenic (As), and selenium $(\mathrm{Se})$ in composite samples of whole fish

32. Maximum concentrations of TCDD-EQ in composite samples of whole fish and mean hepatic Ethoxyresorufin 0 -deethylase activity in carp and bass (Micropterus sp.)................... 84

33. Percentages of male bass from the indicated stations in which ovotestis was detected through histopathological examination of the gonads.

\section{Tables}

1. Location, program of origin, and collection dates of sampling stations in the Rio Grande Basin...

2. Methods used to assess contaminant exposure and effects in fish from the Rio Grande Basin

3. Organochlorine chemical and elemental contaminants measured in composite fish samples.

4. Monitoring and assessment strategy for polycyclic aromatic and polyhalogenated hydrocarbons (PAH and $\mathrm{PHH}$ ).

5. Results of quality assurance (Q/A) analyses and limits-of-detection (LODs) for elemental contaminants.

6. Results of quality assurance (Q/A) analyses and nominal limits of detection (LODs) for organochlorine chemical residues.

7. Fishes collected in the Rio Grande Basin..

8. Total lengths, weights, and ages of common carp collected in the Rio Grande Basin, by station and gender

9. Total lengths, weights, and ages of bass (Micropterus sp.) collected in the Rio Grande Basin, by station and gender

10. Occurrence (percentages of samples and stations) and censoring levels for elemental contaminants in composite samples of whole fish from the Rio Grande Basin

11. Geometric mean, minimum, and maximum concentrations ( $\mu \mathrm{g} / \mathrm{g}$, wet-weight) of elemental contaminants in fish from stations in the Rio Grande Basin

12. Least-squares mean concentrations of $p, p^{\prime}-\mathrm{DDE}$, mercury $(\mathrm{Hg})$, length-adjusted $\mathrm{Hg}(\mathrm{HgL})$, weight-adjusted $\mathrm{Hg}(\mathrm{Hg})$, arsenic (As), cadmium $(\mathrm{Cd})$, lead $(\mathrm{Pb})$, zinc $(\mathrm{Zn})$, and selenium (Se)

13. Least-squares mean concentrations of $p, p^{\prime}$-DDE, mercury $(\mathrm{Hg})$, length-adjusted $\mathrm{Hg}(\mathrm{HgL})$, weight-adjusted $\mathrm{Hg}(\mathrm{HgW})$, arsenic $(\mathrm{As})$, cadmium $(\mathrm{Cd})$, lead $(\mathrm{Pb})$, zinc $(\mathrm{Zn})$, and sele$\operatorname{nium}(\mathrm{Se})$

14. Geometric mean concentrations of mercury $(\mathrm{Hg})$ in bass a from Stations 16 and 63, 19701997

15. Occurrence of organochlorine chemical residues in composite samples of whole fish from the Rio Grande Basin 
16. Geometric mean, minimum, and maximum concentrations of organochlorine chemical residues in fish from stations in the Rio Grande Basin.

17. Results of preliminary analysis-of-variance investigating the effects of various factors on biomarker a responses in carp and bass (Micropterus sp.)

18. Geometric means and ranges of EROD activities, by species, station and gender ................. 56

19. Percentages of carp, bass (Micropterus sp.), and all fish from the Rio Grande Basin with external lesions, by station. Also shown are the numbers of fish with lesions and of fish in each category examined.....

20. Distribution of Health Assessment Index (HAl) scores in carp and bass (Micropterus sp.) from the Rio Grande Basin, by station...

21. Age-adjusted station means for splenic macrophage aggregate (MA) parameters in carp and bass (Micropterus sp.).

22. Summary of chemical and biological indicator results, by sub-basin and station.

23. Statistically significant correlations a between biological and chemical endpoints in bass (Micropterus sp.), carp, and catfish (/ctalurus sp.) from the Rio Grande Basin

\section{Conversion Factors}

\begin{tabular}{lcl}
\hline Multiply & By & To obtain \\
\hline & Length & \\
centimeter $(\mathrm{cm})$ & 0.3937 & inch $(\mathrm{in})$ \\
millimeter $(\mathrm{mm})$ & 0.03937 & inch $(\mathrm{in})$ \\
meter $(\mathrm{m})$ & 3.281 & foot $(\mathrm{ft})$ \\
kilometer $(\mathrm{km})$ & 0.6214 & mile $(\mathrm{mi})$ \\
\hline & Area & \\
\hline square kilometer $\left(\mathrm{km}^{2}\right)$ & 0.3861 & square mile $(\mathrm{mi})$ \\
cubic kilometer $\left(\mathrm{km}^{3}\right)$ & 0.2399 & cubic mile $\left(\mathrm{mi}^{3}\right)$ \\
\hline & Volume & \\
\hline milliliter $(\mathrm{mL})$ & 0.03381 & fluid ounce $(\mathrm{fl} . \mathrm{oz})$ \\
liter $(\mathrm{L})$ & 1.057 & quart $(\mathrm{qt})$ \\
liter $(\mathrm{L})$ & 0.2642 & gallon $(\mathrm{gal})$ \\
cubic meter $\left(\mathrm{cm}^{3}\right)$ & 0.0002642 & million gallons $(\mathrm{Mgal})$ \\
\hline & Mass & \\
\hline kilogram $(\mathrm{kg})$ & 2.205 & pound, avoirdupois $(\mathrm{lb})$ \\
& Concentration & \\
\hline microgram per gram $(\mu \mathrm{gg} / \mathrm{g})$ & $=$ & part per million $\left(\mathrm{ppm} ; 10^{6}\right)$ \\
nanogram per gram $(\mathrm{ng} / \mathrm{g})$ & $=$ & part per billion $\left(\mathrm{ppb} ; 10^{9}\right)$ \\
picogram per gram $(\mathrm{pg} / \mathrm{g})$ & $=$ & part per trillion $\left(\mathrm{pptr} ; 10^{12}\right)$ \\
milligram per millimeter $(\mathrm{mg} / \mathrm{mL})$ & $=$ & part per thousand $\left(\mathrm{ppt} ; 10^{3}\right)$ \\
milligram per liter $(\mathrm{mg} / \mathrm{L})$ & $=$ & part per million $\left(\mathrm{ppm} ; 10^{6}\right)$ \\
microgram per liter $(\mu \mathrm{g} / \mathrm{L})$ & $=$ & part per billion $\left(\mathrm{ppb} ; 10^{9}\right)$ \\
\hline
\end{tabular}

Temperature in degrees Celsius $\left({ }^{\circ} \mathrm{C}\right)$ may be converted to degrees Fahrenheit $\left({ }^{\circ} \mathrm{F}\right)$ as follows:

$$
{ }^{\circ} \mathrm{F}=\left(1.8 \times{ }^{\circ} \mathrm{C}\right)+32
$$

Temperature in degrees Fahrenheit $\left({ }^{\circ} \mathrm{F}\right)$ may be converted to degrees Celsius $\left({ }^{\circ} \mathrm{C}\right)$ as follows:

$$
{ }^{\circ} \mathrm{C}=\left({ }^{\circ} \mathrm{F}-32\right) / 1.8
$$


Environmental Contaminants and their Effects on Fish 


\title{
Biomonitoring of Environmental Status and Trends (BEST) Program: Environmental Contaminants and their Effects on Fish in the Rio Grande Basin
}

\author{
By Christopher J. Schmitt', Gail M. Dethloff², Jo Ellen Hinck', Timothy M. Bartish³, Vicki S. Blazer ${ }^{4}$, James J. \\ Coyle $^{3}$, Nancy D. Denslow ${ }^{5}$, and Donald E. Tillitt ${ }^{1}$
}

\section{Abstract}

We collected, examined, and analyzed 368 fish of seven species from 10 sites in the Rio Grande Basin (RGB) during late 1997 and early 1998. Four sites were National Contaminant Biomonitoring Program (NCBP) stations where organochlorine and elemental contaminants in fish had been monitored from 1969 through 1986. The other six were USGS-National Stream Quantity Accounting Network (NASQAN) stations where water quality is monitored. The objectives were to document temporal and geographic trends in the concentrations of accumulative organic and inorganic contaminants in RGB fish and the effects of contaminants on the fish; to continue testing the feasibility of incorporating biomarkers (that is, biochemical, histopathological, and other biological indicators of contaminant exposure or effects) into a monitoring program for large U.S. rivers; and to evaluate the compatibility of monitoring methods based on the analysis of fish with those used to monitor water by NASQAN. Common carp (Cyprinus carpio; carp) and black basses (Micropterus sp.; bass) were the targeted species; together, they represented $77 \%$ of the fish collected. Each fish was examined in the field for externally and internally visible gross lesions, selected organs were weighed to compute various ponderal and organosomatic indices, and samples of tissues and fluids were obtained and preserved for analysis of fish health and reproductive biomarkers. Composite samples of whole fish from

${ }^{1}$ U.S. Geological Survey, Columbia Environmental Research Center (CERC), 4200 New Haven Road, Columbia, MO 65201.

${ }^{2}$ AScI, c/o U.S. Geological Survey, Columbia Environmental Research Center (CERC), 4200 New Haven Road, Columbia, MO 65201.

${ }^{3}$ U.S. Geological Survey, Office of the Chief Science-Biologist, 12201 Sunrise Valley Drive, MS-300, Reston, VA 20192.

${ }^{4}$ U.S. Geological Survey, Leetown Science Center, 1700 Leetown Road, Kearneysville, WV 24530.

${ }^{5}$ Protein Chemistry and Molecular Biomarkers Laboratory, P.O. Box 100156 Health Center, University of Florida, Gainesville, FL 32610. each station were grouped by species and gender and analyzed by instrumental methods for persistent organic and inorganic contaminants and for dioxin-like activity (TCDD-EQ) using the H4IIE rat hepatoma cell bioassay.

Overall, fish from stations in the lower RGB contained greater concentrations of some contaminants and appeared to be less healthy than those from sites in the central and upper parts of the basin, as indicated by general gradient of pesticide concentrations and biomarker responses from upstream to downstream. In the upper RGB, a minimal number of altered biomarkers and few or no elevated contaminant concentrations were noted. The exception was elevated concentrations [up to $0.46 \mu \mathrm{g} / \mathrm{g}$ wet-weight (ww)] of total mercury $(\mathrm{Hg}$ ) in predatory species from Station 63 (Rio Grande at Elephant Butte Reservoir, NM), a condition noted in the past.

Elemental contaminants were most evident in fish from sites in the central RGB. Fish from Station 514 (Rio Grande at Amistad International Reservoir) contained slightly elevated concentrations (1.1-1.5 $\mu \mathrm{g} / \mathrm{g} \mathrm{ww}$ ) of selenium (Se) and were also characterized by comparatively high organosomatic indices, proportions of fish with external lesions, and health assessment index (HAI) scores. Bass from Station 514 also contained elevated concentrations of total $\mathrm{Hg}$ (up to $0.4 \mu \mathrm{g} / \mathrm{g}$ ww). Se concentrations were also elevated ( $>1.0 \mu \mathrm{g} / \mathrm{g} \mathrm{ww})$ in carp from Station 515 (Rio Grande at Langtry, TX), and arsenic (As) concentrations were comparatively high $(>0.3$ $\mu \mathrm{g} / \mathrm{g} \mathrm{ww}$ ) in some samples from Stations 65 (Pecos River at Red Bluff Lake, TX) and 514. A comparatively large percentage of the carp from Station 515 also had high HAI scores caused primarily by the presence of parasite-induced external lesions. Concentrations of As and Se in fish from Station 65 were lower than in the past, but Se concentrations at this site as well as others in the central RGB were sufficiently high to represent a threat to fish and wildlife.

In the lower RGB, organochlorine pesticide residues (DDT metabolites, chlordane-related compounds, dieldrin, and toxaphene) were evident in fish from most sites, and concentrations exceeded toxicity thresholds for fish and wildlife at 
Stations 16 (Rio Grande at Mission, TX), 511 (Arroyo Colorado at Harlingen, TX), and 512 (Rio Grande at Brownsville, TX). Arsenic concentrations were also comparatively high (about $0.3 \mu \mathrm{g} / \mathrm{g} \mathrm{ww}$ ) in bass from Station 512. Channel catfish (Ictalurus punctatus) from Station 511 contained especially high (by contemporary standards) concentrations of $p, p^{\prime}-\mathrm{DDE}$ (1.3-1.6 $\mu \mathrm{g} / \mathrm{g} \mathrm{ww})$, chlordane-related residues $(0.13-0.21 \mu \mathrm{g} / \mathrm{g}$ ww), toxaphene (1.4-2.4 $\mu \mathrm{g} / \mathrm{g} \mathrm{ww})$, and dieldrin (0.03-0.05 $\mu \mathrm{g} /$ $\mathrm{g} \mathrm{ww})$. These concentrations nevertheless represent a substantial decline relative to those reported historically. In addition, little or no $(<0.01 \mu \mathrm{g} / \mathrm{g} \mathrm{ww}) p$, $p^{\prime}$-DDT was detected at any site; nearly all DDT-derived residues were $p, p$ '-DDE. Declining overall residue concentrations and increasing proportions of $p, p$ '-DDE in 1997 samples relative to the past collectively indicate the weathering and re-distribution of old DDT rather than the influx of new pesticides to the lower RGB. Conversely, proportionally high concentrations of cis-chlordane relative to trans-nonachlor in fish from Station 511 indicates more recent pesticide inputs.

Concentrations of total PCBs $(<0.05 \mu \mathrm{g} / \mathrm{g} \mathrm{ww})$ and TCDD-EQ ( $\leq 6 \mathrm{pg} / \mathrm{g}$ ww) were comparatively low in all RGB samples, but rates of ethoxyresorufin $O$-deethylase (EROD) activity in carp, bass, channel catfish, or multiple species were elevated above basal rates at all sites. Collectively, these findings indicate that the fish had been exposed to polycyclic aromatic hydrocarbons (PAH). Environmental PAH can originate from petroleum, the incomplete combustion of coal, and from industrial activities such as smelting and metal fabrication; the former is consistent with the widespread energy extraction and transportation activities that occur throughout much of the RGB. Although elevated relative to basal activity in these species, EROD activity in RGB fish was generally low relative to levels reported in fish of the same species collected by others from heavily contaminated locations. In addition to EROD, slightly elevated HAI scores characterized carp from Station 511 and a comparatively high frequency of external lesions was noted on bass at Station 512. Histopathological examination revealed that the latter were parasite-induced. Comparatively high individual HAI values were noted at Stations 16, 512, and 513, and one or more macrophage aggregate parameters were elevated in carp, bass, or both at all lower RGB stations. Reproductive biomarkers were also consistent with chronic contaminant exposure at the four lower RGB sites; comparatively large percentages of intersex male bass, relatively low gonadosomatic index scores, and elevated vitellogenin concentrations in male fish were noted at three of the four stations, and large percentages of atretic eggs were observed in the ovaries of female carp from Station 512. Although there are other causes for many of the conditions noted, the biomarker data for the lower RGB stations are nevertheless consistent with subtle responses to contaminants, an interpretation supported by the chemical data of this and other recent investigations.

\section{Introduction}

The Rio Grande (RG), known as the Rio Bravo del Norte in Mexico, represents a vital source of water to the growing human population of the Southwestern U.S. and northern Mexico and to the fish and wildlife resources of the region. Together with the Rio Conchos, a northward-flowing tributary that originates in Mexico, the RG provides irrigation water for agriculture from its headwaters in the San Juan Mountains of Colorado to the Texas Gulf Coast (Fig. 1). Although irrigation accounts for more than $80 \%$ of water withdrawals, $\mathrm{RG}$ water is also important for human consumption and supports water-based recreation. It also sustains riparian and estuarine habitats and the organisms that depend on them. U.S. Department of the Interior (USDI) agencies manage large tracts within the RGB in Colorado and New Mexico as well as much of its hydrologic infrastructure and many conservation and recreation facilities associated with the river and its tributaries (Fig. 1). The U.S. Fish and Wildlife Service (USFWS), a USDI agency, is also responsible for the many migratory birds and jeopardy-status species inhabiting these lands and waters.

Heavy and increasing demands are placed on RG waters to meet growing water supply and waste disposal needs of population centers in the U.S. and Mexico, which have also affected water and habitat quality. Natural, agricultural, industrial, and urban erosional processes contribute to high sediment loads, and dams and diversions have dramatically altered flow regimes and water quality. Although the RG was historically characterized by elevated concentrations of dissolved solids, salinity has been increased by water removal, irrigation return flows, and structural alterations, especially in lower reaches (Mora and Wainwright, 1997). Elevated concentrations of organochlorine pesticides such as DDT and its metabolites have been found historically in sediments and river-dependent organisms, as have elevated concentrations of metals and metalloids in water, sediment, and biota (Davis and others, 1995; Levings and others, 1998; Mora and Wainwright, 1997; Mora and Wainwright, 1998; Schmitt and others, 1999b; Texas Natural Resources Conservation Commission (TNRCC), 1994a; 1997). Accordingly, many previous studies have characterized the biota in parts of the RGB as being at risk from contaminants.

The RG and the Pecos River (PR), the largest U.S. tributary of the RG, were studied by the USGS in late 1997 and early 1998. As part of the USGS Biomonitoring of Environmental Status and Trends (BEST) program, the primary objectives of the study were to document the occurrence and distribution of contaminants and their effects on fish in the largest rivers of the RGB; and to evaluate the potential risk represented by these contaminants to other biota. Secondary objectives were to compare biomonitoring results from the RGB to other major river systems in North America, and to further define benchmarks for the quantification of long-term trends and interpretation of biomarker results. These latter objectives were achieved by building on the results of a similar 


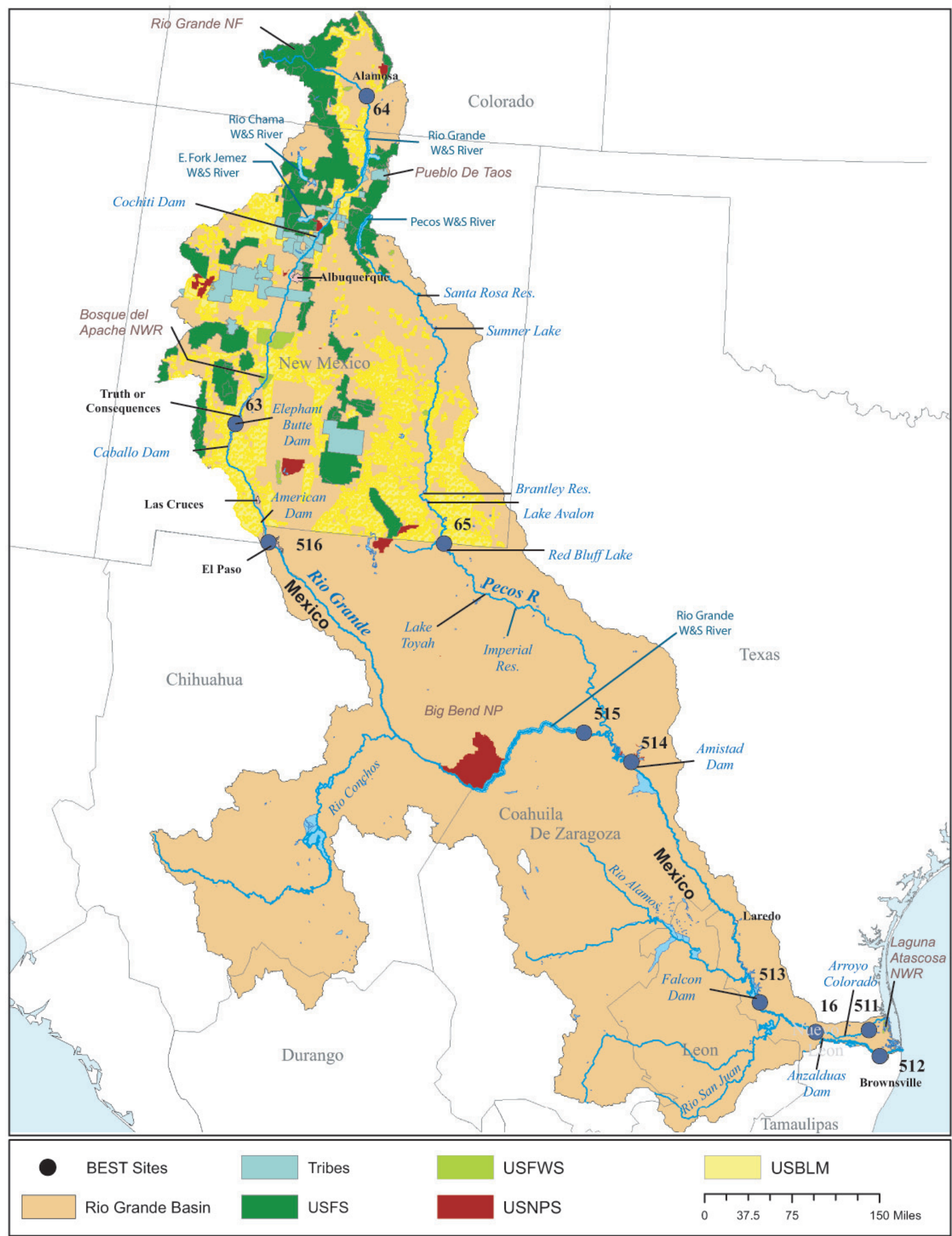

Figure 1. Map of the Rio Grande Basin illustrating waterways and impoundments, Federal and Native American lands and facilities, major metropolitan areas, state boundaries, and locations sampled. Shown are Native American Tribal lands (Tribes) and lands managed by the U.S. Forest Service (USFS), Fish and Wildlife Service (USFWS), National Park Service (USNPS), and Bureau of Land Management (USBLM). See Table 1 for station descriptions and collection dates. 
investigation conducted in the Mississippi River Basin (MRB) in 1995 (Schmitt, 2002a). The RGB study was conducted in conjunction with a similar 1997 investigation of the Columbia River Basin. Together, the 1997 projects were also designed to evaluate the compatibility of the BEST large rivers component with the USGS National Stream Quantity Accounting Network (NASQAN) program, which monitors concentrations of dissolved pesticides and other constituents in the waters of the largest U.S. rivers (Hooper and others, 2001). Collection of contemporary information on contaminants in fish also provides linkages to and continuity with other historical and contemporaneous data sets (Carter and Anderholm, 1997; Gamble and others, 1988; Levings and others, 1998; Schmitt and others, 1999b; TNRCC, 1994a; 1997; U.S. Environmental Protection Agency (USEPA),1992a; 1992b). The availability of a regional contaminant assessment (Mora and Wainwright, 1997), and associated database (Mora, 2001), provided an informational framework to support interpretation of the 1997 results.

Findings of the RGB study are reported here. The data have also been incorporated into a national database (<http:// www.cerc.usgs.gov/data/data.htm>). Results from this study, together with those from similar investigations conducted in other river basins, will help resource managers and scientists assess contaminant impacts on fish and on wildlife and human consumers of those fish, and to identify areas that warrant further investigation of contaminant threats.

\section{Rio Grande Basin Overview}

\section{Hydrology and Infrastructure}

The RG originates in the southern Colorado Rocky Mountains within the Rio Grande National Forest. It flows generally southward into and through New Mexico, entering Texas northwest of El Paso. Below El Paso, the river tracks southeasterly before reaching the Big Bend area, roughly 90 mi (145 km) downstream from Presidio (Fig. 1). The RG then changes course at the apex of the Big Bend, flowing northeasterly for another $90 \mathrm{mi}(145 \mathrm{~km})$ before bearing east and then southeasterly again towards its terminus in the Gulf of Mexico.

At approximately 1,901 $\mathrm{mi}(3,059 \mathrm{~km})$ in length, the RG is the second longest U.S. river (Fig. 1) (TNRCC, 1997). It represents the international boundary between the United States and Mexico from El Paso to the Gulf of Mexico, a distance of about 1,276 mi (2,053 km) (TNRCC, 1997). The RGB is also large in area, encompassing about $335,500 \mathrm{mi}^{2}$ $\left(924,300 \mathrm{~km}^{2}\right)$. Of this total, about $88,968 \mathrm{mi}^{2}\left(231,317 \mathrm{~km}^{2}\right)$ in the U.S. (in Colorado, New Mexico, and Texas) and 87,968 $\mathrm{mi}^{2}\left(227,149 \mathrm{~km}^{2}\right)$ in Mexico (in Chihuahua, Coahuila, Nuevo Leon, Tamaulipas, and Durango) contribute flow to the RG (TNRCC, 1997). The remaining areas within the RGB comprise endorheic (closed) basins. The U.S. portion of the RGB below El Paso comprises 48,300 $\mathrm{mi}^{2}\left(125,580 \mathrm{~km}^{2}\right)$, of which $38,800 \mathrm{mi}^{2}\left(100,880 \mathrm{~km}^{2}\right)$ contribute flow (TNRCC, 1997). More than 20 Native American nations are located within the U.S. parts of the RGB (Fig. 1).

Snowmelt from the Rocky Mountains is the primary source of surface water to the RG. Flow is augmented by diversions from the Colorado River Basin via the San JuanChama Project and by groundwater and available surface water pumped out of the 2,940 $\mathrm{mi}^{2}\left(7,617 \mathrm{~km}^{2}\right)$ San Luis Valley closed basin. The Chama River and Rio Puerco represent major upper basin tributaries. Between El Paso and the Big Bend of Texas the Rio Conchos, which flows northward from the Sierra Madre Mountains in Chihuahua, Mexico, joins the RG near Presidio and contributes most of the flow. Below the Big Bend the major tributaries are the PR, which drains parts of eastern New Mexico and western Texas and joins the RG upstream of Amistad International Reservoir; and the Devil's River, which drains parts of south-central Texas and joins the RG within Amistad International Reservoir (Fig. 1).

A complex network of flow-control structures has been constructed on the RG and many of its tributaries to provide water storage and flood/sediment control and to meet interstate and international water delivery obligations. Much of the hydrologic infrastructure in Colorado and New Mexico is operated by the USDI Bureau of Reclamation (USBR). Cochiti Reservoir, located roughly $50 \mathrm{mi}(80 \mathrm{~km})$ north of Albuquerque, New Mexico is the northernmost major impoundment on the RG mainstem (Fig. 1). Below Cochiti Reservoir, the Angostura Dam diverts water to supply parts of the Middle Rio Grande Conservancy District. Waters from the Jemez Canyon Reservoir enter the RG below Angostura Dam, upstream of Albuquerque. Below Albuquerque, water is diverted again at the Isleta Diversion Dam. To reduce excessive evaporative losses below San Acacia, New Mexico, a 70-mi (113-km) canal known as the Low Flow Conveyance Channel (LFCC) was constructed parallel to the RG in the 1950s; however, subsequent sedimentation of the structure necessitated its closure as a conveyance. Currently, the LFCC collects agricultural return flows from irrigated areas near the river and provides water to the Bosque del Apache National Wildlife Refuge (NWR; Fig. 1). Downstream of the refuge, the entire flow of the RG is captured by Elephant Butte Reservoir (USBR), then again by Caballo Reservoir (USBR; Fig. 1). Exiting Caballo Reservoir, the RG flows southwesterly along the western edge of Las Cruces, New Mexico and enters Texas northwest of El Paso. Above El Paso, at the American Dam (USBR), nearly all the remaining water is diverted into the American Canal (U.S.) and the Acequia Madre (Mexico) for agricultural and municipal uses.

The waters of the RG and its hydrologic infrastructure downstream of Fort Quitman, Texas (east of El Paso) are managed by the International Boundary and Water Commission (IBWC) of the U.S. Department of State according to the terms of several treaties with Mexico (TNRCC, 2002). For about $250 \mathrm{mi}(402 \mathrm{~km}$ ) below El Paso to the confluence of the Rio Conchos near Presidio, Texas, flows in the RG are inter- 
mittent and comprise storm runoff, irrigation return waters, and municipal waste effluents (Mora and Wainwright, 1997). From Presidio downstream to Amistad International Reservoir and the confluence of the PR most of the water in the RG originates in Mexico and is contributed by the Rio Conchos (Fig. 1).

The PR originates in the Sangre de Cristo Mountains east of Santa Fe, New Mexico and flows some 926 mi (1,480 $\mathrm{km})$ southward and eastward across New Mexico and Texas to its confluence with the RG near Langtry, Texas near the upstream end of Amistad International Reservoir (Fig. 1). The PR drains some $38,300 \mathrm{mi}^{2}\left(99,228 \mathrm{~km}^{2}\right)$. Over its length the PR is controlled by a series of impoundments and other water management structures from which water is diverted for agriculture and other uses. Impoundments on the PR in New Mexico include Brantley Reservoir (formerly Lake McMillan), Lake Sumner (formerly Alamogordo Reservoir), Santa Rosa Lake, and Avalon Lake. Of these, all but Santa Rosa Lake are operated by the USBR. Impoundments in the PR Basin in Texas include Red Bluff Lake, Lake Toyah, and Imperial Reservoir (Fig. 1).

Upstream of Del Rio/Ciudad Acunua the waters of the RG, along with those of the Pecos and Devil's Rivers, are impounded by Amistad International Reservoir (Fig. 1). Below Amistad Dam the river is free-flowing for $273 \mathrm{mi}$ $(440 \mathrm{~km})$ until it is again impounded in Falcon International Reservoir (Fig. 1). From Falcon Dam to the Gulf of Mexico, a distance of $298 \mathrm{mi}(480 \mathrm{~km})$, the RG is again generally freeflowing; however, much of the flow is diverted into the Arroyo Colorado (AC) at the Anzanaldus Dam, north of Hidalgo, Texas (Fig. 1). The AC, a distributary, is managed for flood control via a series of floodways as well as for irrigation. It ultimately flows through the Laguna Atascosa NWR and then into the Lower Laguna Madre. The remainder of the RG continues southeasterly, passing through the outskirts of Brownsville, Texas before discharging into the Gulf of Mexico (Fig. 1).

Water resources development has also been extensive in Mexico, and additional projects are being planned. In addition to Amistad and Falcon International Reservoirs, there are currently 13 storage reservoirs on RG tributaries in Mexico. Of these, seven [San Gabriel, Boquilla, F.I. Madero, Pico Del Aguila, Chihuahau, El Rejon, and El Granero (Luis Leon)] are in the Rio Conchos basin; two are in each of the Rio San Diego (Centenario and San Miguel) and Rio San Juan (El Cuchillo and Marte Gomez) basins; and there is one in each of the Rio San Rodrigo (La Fragua) and Rio Saldado (Venustiano Arranza) basins (TNRCC, 2002).

\section{Ecoregions and Climate}

The RGB lies entirely within the dry domain ecoregion as defined by Bailey (1995). Most of the Colorado parts of the basin are classified as temperate steppe. Annual rates of precipitation in Colorado are heterogeneous, however; they range from as much as 44 inches $(112 \mathrm{~cm})$ in the western alpine areas (mostly as snowfall) to as little as eight inches $(20 \mathrm{~cm})$ in the central portions. These precipitation patterns and ecosystem designations extend into the central portion of the basin in New Mexico. Most of the RGB in New Mexico receives less than 14 inches $(36 \mathrm{~cm})$ of precipitation annually, and much of the upper basin ranges from tropical/subtropical steppe and mountain to temperate steppe and mountain. The central part of the basin within New Mexico is primarily tropical/subtropical mountain surrounded on both sides by tropical/subtropical desert. From El Paso through the Big Bend area, the RGB is classified as tropical/subtropical desert except for the extreme eastern edge of the basin, which is tropical/subtropical steppe (Bailey, 1995), this area generally receives less than 14 inches $(36 \mathrm{~cm})$ of precipitation annually. Precipitation increases with distance below the Big Bend; much of the lower RGB receives 20 inches $(51 \mathrm{~cm})$ annually, and the areas nearest the Gulf Coast receive as much as 28 inches $(71 \mathrm{~cm})$. The lower, narrow portion of the RGB extending from Eagle Pass to the Gulf is therefore classified as tropical/subtropical steppe (Bailey, 1995).

\section{U.S. Department of the Interior (USDI) Resources at Risk from Contaminants in the Rio Grande}

Large tracts within the RGB in Colorado and New Mexico are managed by the U.S. Forest Service (Department of Agriculture) and the USDI Bureau of Land Management (BLM; Fig. 1). The USDI lands support multiple uses, including wildlife habitat and water-based recreation such as sport fishing. Because demands for water have greatly reduced the amount and quality of riparian and wetland habitat in the RGB, much of the remaining habitat and many of the organisms it supports are under USDI stewardship. Refuges associated with the RG and its major tributaries are managed by the USFWS. These include Alamosa and Monte Vista NWRs in Colorado; Bosque del Apache, Sevellita, Las Vegas, and Bitter Lake NWRs in New Mexico; and Lower Rio Grande Valley, Santa Ana, and Laguna Atascosa NWRs in Texas. Many of the refuges in the RGB were identified as being at risk of injury from pesticides, selenium (Se), salt seepage, and other contaminants emanating from agriculture and oil and gas production (U.S. Fish and Wildlife Service (USFWS), 1986). Laguna Atascosa NWR is situated on the landward side of the Laguna Madre at the confluence of the AC (Fig. 1). The AC, which flows through and supplies fresh water to the refuge, is heavily contaminated by agricultural chemicals and is the primary reason that Laguna Atascosa is among the RGB refuges identified as being at risk due to contaminants (Gamble and others, 1988; USFWS, 1986). The Mercedes Unit of Rio Grande Valley NWR, along with state and private refuges, are situated on the north shore of the AC at Llano Grande Lake, upstream of Harlingen, Texas (MacWhorter, 2004). Llano Grande Lake has a long history of contamination by organo- 
chlorine pesticides and it remains under a fish consumption advisory [unpublished Texas Deparment of Health (TDH) data summarized by Mora (2001; Mahler and Van Metre, 2002; White and others, 1983).

Federal recreational resources associated with the RG are also significant. The 68-mi (109 km) segment extending from the Colorado-New Mexico boundary downstream to Taos County, along with the lower $4 \mathrm{mi}(6.4 \mathrm{~km})$ of the Red River, have been designated as Wild and Scenic Rivers (WSRs) by the U.S. National Park Service (USNPS) and BLM of the USDI; this segment hosts the Wild Rivers and Orilla Verde National Recreation areas. Wild and Scenic status has also been proposed for Rio Embudo, another tributary. Elevated concentrations of metals from historical mining have been reported in fish and sediments of the Red River (Carter and Anderholm, 1997; Levings and others, 1998; Roy and others, 1992). In addition, these waters may all be affected by a proposed copper mine. Farther downstream in New Mexico, the RG represents the southeast boundary of Bandelier National Monument (USNPS) in White Rock Canyon. Segments of the East Fork of the Jemez River, the PR, and the Rio Chama have also been designated as WSRs; the Rio Chama is jointly managed by the U.S. Forest Service and the BLM.

In Texas, the RG represents the $69 \mathrm{mi}(109 \mathrm{~km})$ south boundary of Big Bend National Park (BBNP). This 69-mi reach begins upstream of Mariscal Canyon in BBNP at the Chihuahua/Coahuila border; it and an additional $118 \mathrm{mi}$ (190 $\mathrm{km}$ ) downstream to the Val Verde/Terrell County line also comprise the Rio Grande Wild and Scenic River (Fig. 1). Amistad National Recreation Area is situated on the north shore of Amistad Reservoir and extends upstream along the Rio Grande about $83 \mathrm{mi}$ (134 km), along the Devil's River about $25 \mathrm{mi}(40 \mathrm{~km})$, and along the Pecos River about 14 mi $(23 \mathrm{~km})$. These areas are managed by the USNPS. A cinnabar mine from which mercury $(\mathrm{Hg})$ was extracted and smelted until 1943 is located within BBNP, and other derelict mines and smelters of the Terlingua Mining District are situated nearby (Sharpe, 1980). The seaward boundary of the Laguna Madre is formed by Padre Island, the northern part of which comprises the Padre Island National Seashore (USNPS), a nationally significant recreational and wildlife area that includes nesting habitat for the endangered Kemp's ridely sea turtle (Lepidochelys kempii) and other species of wildlife. Additional recreational and wildlife areas managed by the states are situated along the RG and its tributaries and impoundments; these are also important to migratory species (USDI, 1995).

The cumulative impacts of physical and chemical changes together with the introduction of exotic species such as salt cedar (Tamarix aphylla) have profoundly affected fishes and other river-dependent biota in the RGB (Bogan, 1998). Consequently, some taxa have been extirpated, some have received Federal protection, and others have been proposed for Federal listing (USDI, 1995). The shovelnose sturgeon (Scaphirhynchus platorhynchus), American eel (Anguilla rostrata), phantom shiner (Notropis orca), and the Rio Grande bluntnose shiner (Notropis simus simus) have been extirpated from portions of the RG, and the latter is federally listed as threatened (Propst, 1999). The Rio Grande silvery minnow (Hybognathus amarus), Big Bend gambusia (Gambusia gaigei), and Pecos gambusia (G. nobilis) are endangered, and the Pecos pupfish (Cyprinodon pecosensis) has been proposed for Federal listing; the latter two species now exist only at Bitter Lake NWR, where elevated concentrations of selenium (Se) have been reported (unpublished data, USFWS, Albuquerque, NM). Selenium and pesticides from agriculture and $\mathrm{Hg}$ from historical cinnabar mining in the Terlingua District have been implicated in the reproductive failure of the TransPecos population of peregrine falcons (Falco peregrinus), a threatened species, in areas adjacent to the RG (Mora and others, 2002). The Southwestern willow flycatcher (Empidonax traillii extimus) is endangered primarily because its riparian habitat along the RG and PR has been eliminated by the operation of water projects (El-Hage and Moulton, 1998). Small populations of the endangered interior least tern (Sterna antillarum athalassos) nest at Amistad and Falcon reservoirs and at Bitter Lake NWR, and ocelots (Leopardus pardalis) and jaguarundi (Herpailurus yaguarondi), both endangered, frequent riparian brushlands adjacent to the RG and other waterways and inhabit Laguna Atascosa NWR (USDI, 1995; University of Texas-Pan American (UTPA), 1995). An experimental population of the endangered whooping crane (Grus americana) was established at Bosque del Apache NWR (Roy and others, 1992), which winter at the refuge along with other migratory species. Wetlands in the western Texas parts of PR Basin also host breeding populations of the threatened white-faced ibis (Phlegadis chihi) (El-Hage and Moulton, 1998). Bald eagles (Haliaetus leucocephalus) nest at Elephant Butte and Caballo reservoirs in New Mexico and over-winter along much of the RG, and brown pelicans (Pelecanus occidentalis), whooping cranes, and Eskimo curlews (Numenius borealis) frequent the Laguna Madre (UTPA, 1995). American white pelicans (Pelecanus erythrorhynchos), which were proposed for federal listing, also reside at Falcon Reservoir. Other federally listed plants and animals occur in the RG corridor but are not exclusively associated with riparian habitats (UTPA, 1995).

\section{Extant Sources of Information on Contaminants in the RGB}

Water quality in the RG and its major tributaries has been studied intensively over the last decade in response to dwindling water supplies caused by rapid population growth and economic expansion and prolonged drought. In addition to focused studies, many national investigations and monitoring programs have incorporated RG sites. Relevant findings of these studies were summarized and tabulated for comparison with 1997 results (Appendix Table 1). Information on local sources of contaminants, such as permitted discharges, fish consumption advisories, and hazardous waste sites, was also available from the web-sites of the New Mexico Environment 
Department and the TDH. Additional unpublished TDH data on organochlorine and elemental contaminant concentrations in RGB fish from 1970-97 were available from the database compiled by Mora (2001). Databases of the TNRCC; the Toxic Release Inventory (TRI), Permit Compliance System (PCS), and Comprehensive Environmental Response, Compensation, and Liability Information System (CERCLIS) databases of the USEPA; and the USGS Minerals Availability System (MAS) were accessed and queried for information on documented permits, releases, and facilities that might be influencing water quality in the RGB (Appendix Table 1). Such information was only available from U.S. facilities and sites, however.

The RGB has been the focus of many national and regional investigations over the last three decades. Fish samples collected at four RGB sites (Stations 16, 63, 64, and 65; Table 1) from 1970 through 1986 under the auspices of the NPMP/NCBP (Lowe and others, 1985; Schmitt and Brumbaugh, 1990; Schmitt and others, 1985; 1990; 1999b) were analyzed for organochlorine chemical residues and elemental contaminants. The NASQAN program periodically collected water samples, which were analyzed for a large number of dissolved and suspended constituents including pesticides, nutrients, and trace elements, at six RGB sites sampled in our study (Stations 511-516; Table 1) beginning in 1996 (Wells and Reutter, 1996). In the early 1990s, the NAWQA program studied the upper RGB from its headwaters to El Paso, Texas; the study included the measurement of waterborne pesticides and metals as well as contaminant concentrations in sediments, fish livers (inorganic contaminants), whole fish (organochlorine chemicals) (Carter and Anderholm, 1997; Levings and others, 1998), and bryophytes (Carter and Porter, 1997). White and others (1983) investigated toxaphene and $p, p$ '-DDE concentrations in RGB fish and avian wildlife in the late 1970s; this study included collection sites at Alamosa, Colorado (Station 64), Falcon and Amistad International Reservoirs (Stations 513 and 514), and the AC at Harlingen, Texas (Station 511). The USFWS and USGS studied elemental and organochlorine chemicals in the New Mexico waters of the RG and its tributaries during the late 1980s (Ong and others, 1991; Roy and others, 1992).

The lower RGB has been the subject of especially intense study due to the region's rapid population and economic growth. The USFWS conducted an extensive study of contaminants in lower RGB and Laguna Madre sediments and biota during the mid-1980s (Gamble and others, 1988). A multiphase, interagency assessment titled the "Binational Study Regarding the Presence of Toxic Substance in the Rio Grand/Rio Bravo and its Tributaries Along the Boundary Portion Between the United States and Mexico" (hereafter the Binational Study) was initiated in 1992 under the overall guidance of the IBWC. Participating agencies included USEPA, TNRCC, Texas Parks and Wildlife Department, and TDH of the United States; and the National Water Commission and Secretaria de Desarrollo Social of Mexico. In Phase 1 of the Binational Study, 19 mainstem and 26 tributary sites
(13 in each nation) from El Paso to Brownsville, Texas were assessed using traditional water quality measures; chemical analysis of water, sediment, and fish tissue; toxicity tests on water and sediment; and benthic community indices (TNRCC, 1994b). In early 1994, Davis and others (1995) sampled eight sites in the lower RGB that were not included in Phase 1 of the Binational Study, including the AC (sampled in 1997; Station 511-see Table 1). Phase 2 of the Binational Study was initiated in May 1995; 27 mainstem and 19 tributary were assessed (TNRCC, 1997). In Phase 2, sites that showed little or no impacts in Phase 1 were eliminated for further assessment and 16 new sites were added to provide information on areas not previously assessed; the latter included four sites in Amistad and Falcon International Reservoirs, which we also sampled (Table 1). In addition to chemical measurements, the Binational Study incorporated sediment toxicity and macrobenthic community investigations at some sites, and included extensive reviews of contaminant issues in the RGB. The USEPA included two 1997 RGB sites (Stations 516, RG at El Paso and 511, AC at Harlingen; see Table 1) and a reference site on the Mora River in northeastern New Mexico in its "National Study of Chemical Residues in Fish", which was conducted during the late 1980s (Bahnick and others, 1994; Kuehl and others, 1994; USEPA, 1992a; 1992b). Moring (1999) measured concentrations of waterborne organic chemical residues at six RG sites between Presidio and Brownsville using semipermeable membrane devices (SPMDs) during July-August, 1997. One of these sites was at Del Rio, downstream of our Station 514 (Amistad Reservoir tail water) and one was below Brownsville, near Station 512. Van Metre and others (1997) studied temporal trends in contaminant concentrations based on sediment cores from Elephant Butte Reservoir (our Station 63), Amistad International Reservoir (immediately upstream from Station 514) and Falcon International Reservoir (upstream of Station 513). Mahler and Van Metre (2002) reported on 19892001 temporal trends in sediment cores from Llano Grande Lake, on the AC upstream of Harlingen, Texas.

Several reviews of contaminants in the lower RG have also been completed recently. An overall assessment of contaminants and other water quality issues in Texas parts of the RGB was released the TNRCC in 1994 (TNRCC, 1994a). The results of all lower RG studies through Phase 1 of the Binational Study (TNRCC, 1994b) and Davis and others (1995) were incorporated into a database (Wainwright and others, 2001) and summarized by Mora and Wainwright (1997; 1998); and a review of contaminant discharges from the RG and AC to the Laguna Madre was conducted in 1994 by the University of Texas-Pan American (UTPA, 1995).

Many focused investigations of contaminants and their effects on RG biota have also been conducted. Contaminants in fish from resacas (oxbow lakes) along the lower RG in Texas and Mexico were investigated by Mora and others (2001); this study also incorporated biomarkers. Mora and others (2002) investigated contaminants in peregrine falcons and their prey in Trans-Pecos Texas, and Caldwell and others (1999) reported on $\mathrm{Hg}$ in fish and wildlife from Caballo and 


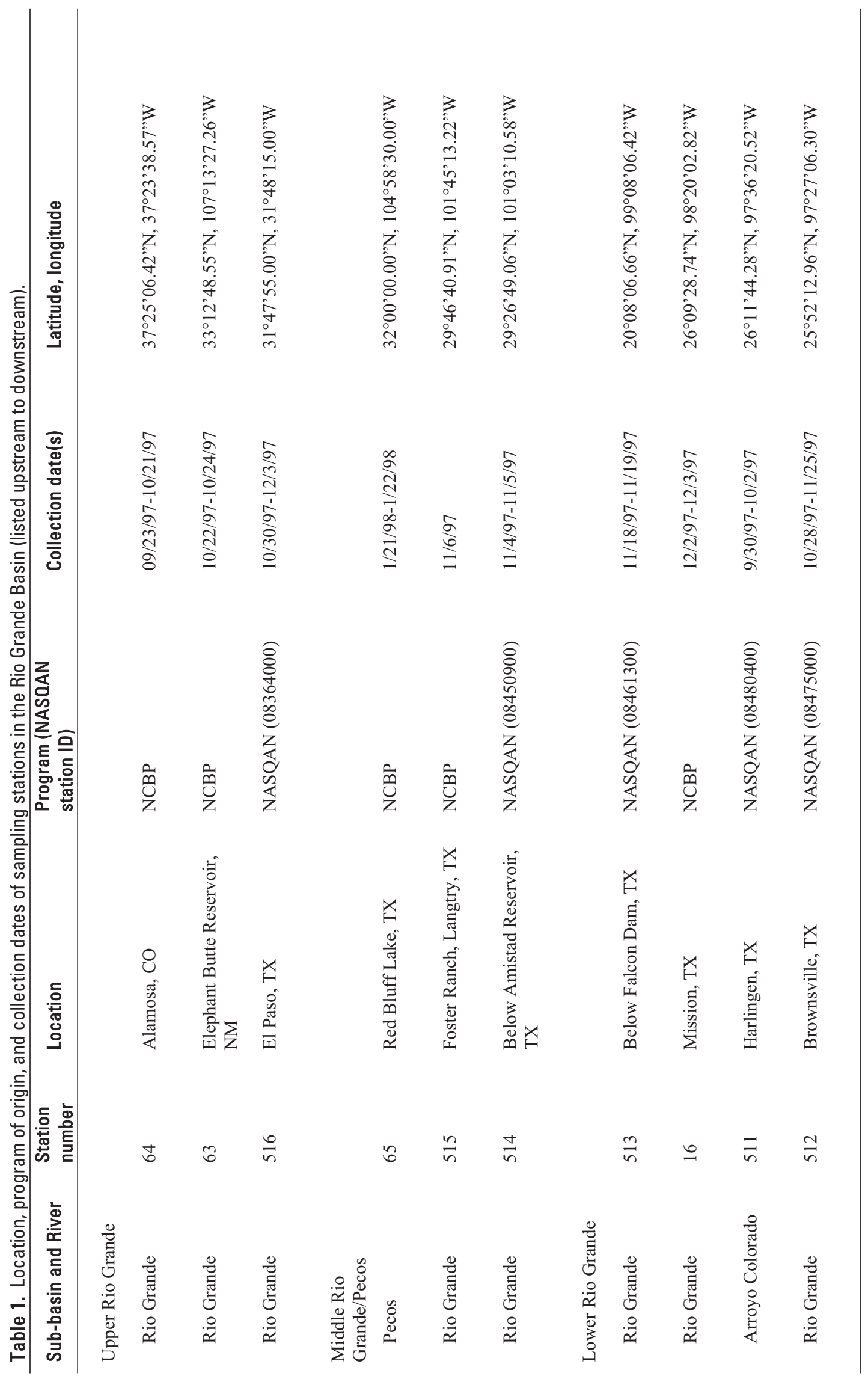


Elephant Butte Reservoirs, NM; the latter was sampled in 1997 (Station 63; Table 1). Ong and others (1991) reported on contaminants in water, sediment and biota in the RG upstream of Elephant Butte Reservoir collected during the 1980s. Wainwright and others (2001) analyzed fish and fish-eating birds collected in 1997 from resacas and settling basins in the lower RG valley for organochlorine chemical residues and indicators of reproductive condition (reproductive biomarkers). Additional unpublished contaminants data for NWRs were available from the USFWS (Albuquerque, New Mexico Field Office).

Beyond the RGB the primary basis of comparison for biomarkers and contemporary concentrations of contaminants in whole fish is the 1995 BEST-MRB study (Schmitt, 2002a) and the references cited therein. The 1995 study, which was the pilot for the investigation reported here, spanned 34 NCBP stations and 13 NAWQA sites distributed throughout the central U.S. and was focused on the same fish species targeted by the RGB study. Additional relevant NAWQA investigations outside of the RGB were conducted in the Red River of the North (RRN) Basin during the early 1990s (Goldstein and others, 1996; Goldstein and DeWeese, 1999). The RRN study is important because it is among the only NAWQA investigations in which whole fish, in addition to liver samples, were analyzed for elemental contaminants and because it represents fish of a species collected in the RGB from an area of the U.S. that is largely unaffected by urban and industrial activities (Goldstein and others, 1996; Goldstein and DeWeese, 1999). The frequency distributions of organochlorine chemical residue concentrations in composite samples of whole bottomdwelling fish collected from 20 NAWQA Study Units in the conterminous United States have been characterized (Wong and others, 2000); these represent useful benchmarks against which to compare results. Mercury in fish has been the topic of recent investigations by NAWQA (Brumbaugh and others, 2001) and the USEPA (Peterson and others, 2002; Yeardley and others, 1998), and was the only inorganic contaminant included in the USEPA National Study of Chemical Residues in Fish (Bahnick and others, 1994; USEPA, 1992a).

\section{Major Sources of Contaminants to the Rio Grande}

Much of the RGB is highly mineralized and arid, and parts of the basin are underlain by petroleum-rich geologic formations. As a result, salts, oil, and potentially toxic trace elements such as arsenic (As), Se, and heavy metals are potentially available for release to the environment. Some areas of the basin are also naturally rich in As and Se. The rates of the processes controlling the release and distribution of these naturally occurring constituents are accelerated by human activities such as irrigation, mining, and oil and gas extraction (Schmitt, 1998), all of which are extensive in the RGB. Accordingly, elevated contaminant concentrations in the large rivers of the RGB emanate primarily from mining, agriculture, and energyrelated activities and from the population centers they support (Appendix Table 1). In addition, the complex systems of dams and diversions has profoundly affected the flux of water and sediments and their associated contaminants throughout the RGB. Irrigation leaches potential toxins from soils, and reservoirs act as sinks in which they may accumulate.

\section{Agriculture}

In the United States, irrigation accounts for more than $80 \%$ of water withdrawals from the RG (TNRCC, 1994b). Irrigated agriculture is concentrated near rivers and where groundwater is available (Levings and others, 1998); consequently, agricultural activities are among the most significant sources of contaminants to the RG and its biota (Appendix Table 1). Pasture, range, and livestock production are distributed throughout the RGB (Metz, 2002; Texas Center for Policy Studies (TCPS), 2002); however, crops grown in various parts of the RGB, and corresponding pesticide uses, vary seasonally in response to economic factors and water availability. In Colorado and New Mexico, the primary crops grown in the RGB are potatoes, barley, wheat, and forage, and substantial logging occurs in the uplands. Crops grown in the central RG valley and PR Basin of New Mexico and western Texas include cotton, peppers, onions, and pecans (El-Hage and Moulton, 1998; Roy and others, 1992). In the Rio Conchos Basin the primary crops are similar; they include pecans, alfalfa, chilies, and peanuts, along with lesser quantities of onions, tomatoes, melons, wheat, cotton, sorghum, and dairy products. In the lower RG valley, where more than $75 \%$ of the geographic area is devoted to agriculture (Fipps, 1991), major crops include cotton, grain sorghum, sugar cane, vegetables, peanuts, and citrus.

Despite the intensity of the irrigated agriculture in the RG valley, relatively few currently used pesticides have been detected in mainstem RG waters by recent investigations. None were detected in the transboundary RG by either Phase 1 or Phase 2 of the Binational Study (TNRCC, 1994b; 1997), and only a few compounds [atrazine, carbaryl, chlorpyrifos, Dacthal ${ }^{\oplus}$ (DCPA), diazinon, malathion, metolachlor, and simazine] were detected by NASQAN prior to the collection of fish for our study in late 1997. Of these, only three compounds (the insecticides chlorpyrifos and malathion and the herbicide atrazine) exceeded current water criteria-all three in the AC at Harlingen, and chlorpyrifos in the RG below Falcon Dam (Appendix Table 1). The maximum atrazine concentration at Harlingen during this period was 8.4 times greater than the current criterion (Appendix Table 1). In the Upper RGB, NAWQA reported the presence of as many as 27 compounds in surface water at some sites located on tributaries, but few were detected at mainstem sites (Levings and others, 1998). USEPA (1992b) reported traces of trifluralin and chlorpyrifos in fish from the RG at El Paso and the AC at Harlingen, and Davis and others (1995) detected chlorpyrifos in two of 23 
lower RG fish samples analyzed. Both of these latter compounds are currently registered and heavily used, and were detected in water samples from the lower RGB by NASQAN. Moring (1999) also detected six contemporary pesticides (trifluralin, metribuzin, pendimethalin, diazinon, Dacthal ${ }^{\circledR}$, and chlorpyrifos) as well as seven organochlorine pesticide residues [ $p, p$ '-DDD, $p, p$ '-DDE, dieldrin, trans-nonachlor, trans-chlordane, $\gamma$-hexacholorocyclohexane $(\mathrm{HCH})$, and pentachloroanisole] in 1997 SPMD samples from the transboundary portions of the RG. Arsenic-containing herbicides and defoliants are used on cotton in several parts of the RGB, and residues of historically used pesticides such as DDT, chlordane, and toxaphene remain elevated in the lower basin. In addition, naturally high salinity and As and Se concentrations have been further elevated by irrigation and other water use activities in some areas (Appendix Table 1).

\section{Municipal Wastes}

Heavy and rapidly increasing demands are being placed on the RG to meet municipal supply and wastewater disposal needs of population centers in the U.S. and Mexico. Although the exact human population of the RGB is unknown and growing rapidly, it was conservatively estimated at nearly 10 million in 1992, of which only about 2 million resided in the United States (TNRCC, 1994a). Most of the RGB is sparsely populated; human inhabitants are generally concentrated in population centers located in the river corridors. In the RG corridor these include Taos, Santa Fe, Albuquerque, Truth or Consequences, and Las Cruces, New Mexico; El Paso, Presidio, Del Rio, Eagle Pass Laredo, Zapata, McAllen, Mission, Harlingen, and Brownsville, Texas; and the Mexican cities of Ciudad Juarez, Ojinaga, Ciudad Acuna, Piedras Negras, Nuevo Laredo, Reynosa, Rio Bravo, and Matamoros. Population centers in the PR Basin include Las Vegas, Roswell, Artesia, and Carlsbad, New Mexico; and Pecos, Texas. Flows downstream of El Paso are dominated by irrigation return water, storm water, and effluents from treatment plants. Texas has therefore designated the RG from below Riverside Diversion Dam in El Paso to the confluence of the Rio Conchos as impaired, primarily due to elevated chloride and total dissolved solids concentrations. Much of the rapidly growing portion of the human population inhabiting the lower RG valley resides in areas with inadequate sewage treatment (Chapman and others, 1998; TNRCC, 2002). Segments of the lower RG have therefore been designated as impaired due to the presence of pathogens such as fecal coli form bacteria (Appendix Table 1). In addition, sewage effluents represent significant sources of As in some sections of the RGB where this element is naturally enriched in groundwater (Wilcox, 1997).

\section{Mining and Energy Extraction}

Mining and the extraction of oil and natural gas have profoundly affected biota throughout the RGB. Most mining for metals occurs in the mineral-rich mountains of the upper RGB, in Colorado and New Mexico. In contrast, and although oil and gas deposits are widespread in the RGB, most oil and gas extraction occurs in the lower RG and PR basins, in southeastern New Mexico and Texas. In Colorado and New Mexico, both historical and active mining sites are situated on USDOI lands. In Texas, oil and gas are extracted from NWRs and mining occurred historically on lands managed by the NPS.

Oil shales and tar sands underlie much of the central parts of the RG and PR basins, and exploitable petroleum resources are widely distributed throughout much of the RGB. Exploitation has been most heavily focused in two areas, the Permian Basin and the Rio Grande Embayment. The Permian Basin is a series of geologic formations beneath the PR valley in southeastern New Mexico and west-central Texas. This area hosts some of the most productive U.S. oil and gas fields; in 1992 the Texas counties comprising the Permian Basin produced over 217 million barrels of oil, and total production for the region through 1992 exceeded 14.9 billion barrels (Vertrees, 2002). In South Texas the lower RG valley from Laredo to the Gulf of Mexico is underlain by components of the Rio Grande Embayment, another series of geologic formations hosting petroleum deposits. Numerous oil and gas wells and associated storage and transportation infrastructure are located in and around the floodplain from Zapata downstream to Brownsville. Pipelines and storage facilities are also distributed throughout the region. In addition to petroleum hydrocarbons, produced waters (that is, the water accompanying petroleum in geologic formations) containing high concentrations of salts, elemental contaminants, and radionuclides are discharged to surface waters from oil and gas production and distribution facilities, and natural gas compression and metering stations represent sources of PCBs and Hg (Schmitt, 1998; Wren and Farrell, 1995).

Coals of varying quality are also present in the RGB. These are located in central New Mexico and along the lower RG near Eagle Pass and Laredo, Texas, where lignite deposits are mined (Henderson and Kleiner, 2002). Active coal mines in Colorado and New Mexico are located outside the RGB (Pfeil and others, 2002); however, coal was mined intensively in the mineral-rich Ortiz Mountains near Madrid, New Mexico until the 1950s (Hoffman, 1999).

Mining for metals is largely concentrated in the upper basin; deposits of copper $(\mathrm{Cu})$, silver, gold, manganese, molybdenum, beryllium, nobium, tin, tungsten, lead $(\mathrm{Pb})$, zinc $(\mathrm{Zn})$, and vanadium have been exploited, and additional mines are being considered. A Cu mine was also planned for a deposit near Dixon, in Taos County, New Mexico; had it been developed it would have drained into tributaries of the Rio Grande Wild and Scenic River.

A search of the USEPA-TRI indicated that most mining sites near the RG are presently inactive, and that many of the 
active sites involve sand, gravel, and similar materials (Appendix Table 1). Several historical mining sites have affected water quality, however. In Colorado, historical silver mining and related activities in the Creede Mining District polluted two RG tributaries, Willow Creek and the Alamosa River. Willow Creek has been contaminated by a variety of elemental contaminants (Carter and Porter, 1997; Levings and others, 1998) and has been listed as an impaired waterway due to low pH (Colorado Department of Public Health and Environment (CDPHE), Water Quality Control Division, 2002). The RG from its confluence with Willow Creek to Wagon Gap [about $8 \mathrm{mi}(13 \mathrm{~km})$ ] is also listed as impaired due to elevated $\mathrm{Zn}$, and from Willow Creek to the City of Del Norte [about $30 \mathrm{mi}$ $(48 \mathrm{~km})$ ] it is considered impaired due to elevated cadmium (Cd). Historically, fish kills occurred in this reach of the RG. Contamination from historical (late 1800s) and recent (19841992) mining operations in the vicinity of the Summitville Superfund site in southwest Colorado has also affected nearly the entire length of the Alamosa River below its confluence with Alum Creek, including Terrace Reservoir. Parts of the Alamosa River are classified as impaired due to depressed $\mathrm{pH}$, elevated waterborne metals concentrations (aluminum, $\mathrm{Cu}$, iron and $\mathrm{Zn}$ ), or both (CDPHE, 2002). The significance of this contamination to the RG is tempered by the fact that due to topography and irrigation diversions in its lower reaches, the Alamosa River rarely flows into the RG (Personal communication: C. Cotton, Colorado State Division of Water Resources, Alamosa, CO 3/14/03). As a result, the RG is not designated as impaired in the vicinity of Station 64 (RG at Alamosa; Appendix Table 1). The Red River, which joins the RG near Questa in Northern New Mexico and is part of the Rio Grande Wild and Scenic River (Fig. 1), has been contaminated by molybdenum mine tailings. Elevated concentrations of $\mathrm{Cd}$, $\mathrm{Pb}$, and $\mathrm{Cu}$ in sediments and $\mathrm{Se}, \mathrm{Cd}, \mathrm{As}$, and $\mathrm{Zn}$ in fish and other biota in the Red River have been documented (Carter and Porter, 1997; Roy and others, 1992). Some gold and silver mining also occurred historically in Trans-Pecos Texas. In addition, and as noted earlier, cinnabar deposits in the Trans-Pecos were exploited historically (Sharpe, 1980), which resulted in significant $\mathrm{Hg}$ contamination of biota in this region (Mora and others, 2002).

Significant deposits of non-metallic minerals with the potential to affect water quality, such as salt, gypsum, potash, barite, talc, fluorspars, and sulfur, are also widely distributed in the RGB and have been exploited to varying degrees. Naturally occurring saline seeps as well as brines pumped from oil wells create water quality problems in many parts of the basin. Uranium mining is also significant. Heavily exploited uranium deposits are located around Grants, in the Rio San Jose-Rio Puerco watershed of west-central New Mexico, where radionuclides and potentially toxic trace elements have been washed into streams and reservoirs through the erosion of natural deposits, production wastes, and tailing piles (Ellis and others, 1993). In Texas, uranium deposits are located in the Trans-Pecos and along the South Texas coastal plain, the latter to within a few kilometers of the RG in Starr County (Eargle and others, 2002). In addition to radionuclides, exploitation of the South Texas uranium deposits has released As, Se, and other trace elements to surface and ground waters (Herbert and others, 2001).

\section{Industry}

There is little industrial development and correspondingly few industrial discharges to the RG or its tributaries in Colorado and northern New Mexico; most permitted point sources are municipal wastewater treatment facilities (Appendix Table 1). In contrast, Albuquerque is home to a variety of manufacturing facilities that produce electronic components, plastics, fertilizer, optics, aircraft engines, petroleum products, and paint. Most of New Mexico's Superfund sites, the bulk of which involve groundwater contamination by organic solvents, are located in or near Albuquerque (Appendix Table 1).

No major industrial sources discharge to the RG downstream of Albuquerque until it passes into Texas. In the El Paso vicinity, discharges originate from a variety of industries including paint, corrugated cardboard, petroleum refining, plastics and resins, metal (primarily copper) and wire production, electronics, and the manufacture of toys and medical supplies (Appendix Table 1). A Pb and $\mathrm{Cu}$ smelter situated on the east bank of the RG at El Paso has been in operation since 1887 (Kohout, 2004). Water quality concerns in this area are therefore directed towards $\mathrm{Cu}$ and pollutants associated with municipal waste effluents and urban runoff; waters from this reach were found to be toxic in short-term tests (Appendix Table 1). Many small manufacturing facilities are located in Laredo and Nuevo Laredo, and large volumes of hazardous materials are transported between the United States and Mexico in this region and are stored there (TNRCC, 2002). The remaining centers of industrial activity in the Texas portions of the RG valley are concentrated primarily in McAllen and Brownsville. Permitted discharges in McAllen originate from plating and polishing facilities and manufacturers of electronic components, aircraft parts, steel springs, and medical supplies. In addition, cyanide was identified as a concern in this area by the Binational Study (TNRCC, 1994b) (Appendix Table 1).

In Brownsville, industrial facilities with permitted discharges manufacture ceramics, non-ferrous wire, and electrical equipment (Appendix Table 1). In Mexico, textile and electronics manufacturing are important and growing rapidly, as are assembly plants for a wide variety of consumer goods (Chapman and others, 1998); however, the extent of contamination emanating from these sources is largely unknown (Chapman and others, 1998; Mora and Wainwright, 1997). Illegal dumping has been identified as a significant problem throughout the border region (TNRCC, 2002).

Superfund sites in Texas also cluster in urban/industrial centers, and four are located in counties adjacent to the RG. Two sites are located in El Paso and are associated with metal plating; both involve soil contaminated with a variety of metals including chromium (Cr), nickel (Ni), As, Cd, and Zn 
(Appendix Table 1). The other two sites are located near the lower end of the RG and involve the storage (Mission, TX) or manufacture (Harlingen, TX) of pesticides. Soil and groundwater contamination are the primary concerns at these sites, but neither is located near the RG and both have undergone remediation (Appendix Table 1).

Elevated concentrations of $\mathrm{Hg}$ in fish from Elephant Butte Reservoir in New Mexico have been reported for more than two decades (Kidd and others, 1974; Schmitt and others, 1999b), and the reservoir remains under a fish consumption advisory (Appendix Table 1). Recent studies have also documented elevated $\mathrm{Hg}$ concentrations in piscivorous birds from this reservoir and Caballo Reservoir, which is just downstream (Caldwell and others, 1999). A combination of atmospheric transport, fires, and natural biogeochemical processes are suspected of maintaining elevated concentrations (Canavan and others, 2000).

Military facilities are also present in the RGB; however, only one is located near the river (Appendix Table 1). Groundwater contamination by fuels, lubricants, and solvents is often associated with military sites. In New Mexico, radionuclides from weapons development at the Los Alamos National Laboratory have been deposited in the RG (Graf, 1994).

\section{Materials and Methods}

\section{Collection Sites and Sampling Dates}

Fish were collected at ten sites in the RGB (Fig. 1; Table 1). Eight of the 10 sites were located on the RG and one each was located on the PR and the AC. Eight sites were located in Texas, one site was in Colorado, and one was in New Mexico. The greatest density of stations was in the lower RGB, downstream of Big Bend (Fig. 1). To ensure spatial and temporal continuity with historical data, four sites were NCBP stations (Schmitt and others, 1999b). The other six were NASQAN stations (Hooper and others, 2001). In keeping with NCBP protocol and other studies (Schmitt, 2002a), fish collection was scheduled for autumn to avoid the spawning season. Most fish were collected between late September and early December 1997, but Station 65 was not sampled until January 1998 (Table 1). At all sites except Stations 64 and 512, which had to be visited twice, sampling was completed during one visit spanning 2-3 d. Station 64 was sampled in late September and again in late October, and Station 512 was sampled in late October and late November (Table 1).

\section{Target Species and Sampling Strategy}

This study was designed to retain comparability with NCBP data (Schmitt and others, 1999b) and other RGB investigations incorporating composite samples of whole fish (Carter and Anderholm, 1997; Davis and others, 1995; Levings and others, 1998; TNRCC, 1994b; 1997; USEPA, 1992a) while also accommodating biological measurements (Table 2) (Schmitt and Dethloff, 2000). Many of the latter are genderspecific and require live or freshly killed individual fish. To standardize fish health and biomarker results, the same species were sought at each site. In previous NCBP collections (Schmitt and others, 1999b), the most prevalent bottom-dwelling species was the common carp (Cyprinius carpio, henceforth carp), and the most prevalent predator species was the largemouth bass (Micropterus salmoides). These were also the species targeted in other BEST projects (Schmitt, 2002a). In addition to their widespread distribution and the abundance of extant contaminant data available for them, the biological endpoints had been most thoroughly tested in these species. Accordingly, carp and largemouth bass were the preferred taxa at all RGB sites. If these taxa could not be obtained, alternate species were permitted. Preferred alternate species included suckers (Catostomidae) as alternate benthivores, and another black bass (Micropterus sp., henceforth bass), or catfish (Ictaluridae) as piscivores. The collection target at each site was 10 (each) adult male and female of each taxon-40 fish per site. Collectors were instructed to obtain adult carp and bass or alternate species of a size representative of those believed to be present at the sites based on extant information, and to avoid extremely large or small fish. More than two species were collected at sites where complete quotas for the target or preferred alternate taxa could not be obtained.

\section{Monitoring Methods Overview}

A suite of chemical and biological methods was employed to characterize the exposure of fish to contaminants and the effects of exposure (Schmitt and Dethloff, 2000). The suite included reproductive biomarkers, measures of cytochrome P450 enzyme induction (to assess response to planar halogenated hydrocarbons $(\mathrm{PHH})$ and $\mathrm{PAH}$, fish health assessments, and chemical analyses of fish carcasses (Table 2). Additional information on these methods is available elsewhere [see (Schmitt, 2002a; Schmitt and Dethloff, 2000; Whyte and others, 2000; 2004) and references cited therein]. Concurrent determination of tissue residue concentrations along with the suite of fish health, immune response, and reproductive assessments supports the interpretation of relationships between chemical exposure and biological responses.

The organochlorine and elemental contaminants analyzed in the composite samples (Table 3) were selected to provide 
Table 2. Methods used to assess contaminant exposure and effects in fish from the Rio Grande Basin.

\begin{tabular}{|c|c|c|c|c|}
\hline Method & Description & $\begin{array}{l}\text { Tissue(s) } \\
\text { examined }\end{array}$ & Sensitivity & $\begin{array}{l}\text { Primary } \\
\text { reference(s) }\end{array}$ \\
\hline Histopathology & $\begin{array}{l}\text { Microscopic examination for } \\
\text { the presence of lesions; can } \\
\text { provide early indication of } \\
\text { chemical exposure }\end{array}$ & $\begin{array}{l}\text { Liver, gill, } \\
\text { gonads, spleen, } \\
\text { and kidney }\end{array}$ & $\begin{array}{l}\text { Overall organism } \\
\text { health and } \\
\text { contaminants }\end{array}$ & $\begin{array}{l}\text { Hinton and others (1992); } \\
\text { Hinton (1993); Goodbred } \\
\text { and others (1997) }\end{array}$ \\
\hline $\begin{array}{l}\text { Ethoxyresorufin } O- \\
\text { deethylase (EROD) } \\
\text { activity }\end{array}$ & $\begin{array}{l}\text { Enzyme induction by planar } \\
\text { hydrocarbons }\end{array}$ & Liver & $\begin{array}{l}\text { PCBs; } \\
\text { chlorinated, } \\
\text { dioxins, and } \\
\text { furans; PAHs }\end{array}$ & $\begin{array}{l}\text { Pohl and Fouts (1980); } \\
\text { Kennedy and Jones (1994); } \\
\text { Whyte and others (2000) }\end{array}$ \\
\hline $\begin{array}{l}\text { Macrophage } \\
\text { aggregate analysis }\end{array}$ & $\begin{array}{l}\text { Macrophages are important in } \\
\text { the immune system, serving as } \\
\text { a first line of defense for the } \\
\text { organism and as an antigen } \\
\text { processing cell }\end{array}$ & Spleen & $\begin{array}{l}\text { Multiple } \\
\text { contaminants } \\
\text { including PAHs } \\
\text { and metals }\end{array}$ & $\begin{array}{l}\text { Blazer and others (1994); } \\
\text { Blazer (1997) }\end{array}$ \\
\hline H4IIE bioassay & $\begin{array}{l}\text { A screening tool to determine } \\
\text { the presence of certain classes } \\
\text { of planar halogenated } \\
\text { compounds }\end{array}$ & $\begin{array}{l}\text { Whole fish } \\
\text { (composite } \\
\text { samples) }\end{array}$ & $\begin{array}{l}\text { PCBs; } \\
\text { chlorinated } \\
\text { dioxins and } \\
\text { furans }\end{array}$ & $\begin{array}{l}\text { Tillitt and others (1991); } \\
\text { Whyte and others (2004) }\end{array}$ \\
\hline Vitellogenin & $\begin{array}{l}\text { A precursor of egg yolk, } \\
\text { normally synthesized in the } \\
\text { liver of female fish }\end{array}$ & Blood plasma & $\begin{array}{l}\text { Endocrine- } \\
\text { modulating } \\
\text { substances }\end{array}$ & Denslow and others (1999) \\
\hline Chemical analyses & $\begin{array}{l}\text { Organochlorine chemical } \\
\text { residues and elemental } \\
\text { contaminants }\end{array}$ & $\begin{array}{l}\text { Whole fish } \\
\text { (composite } \\
\text { samples) }\end{array}$ & Specific analytes & $\begin{array}{l}\text { Schmitt and others } \\
\text { (1999) }\end{array}$ \\
\hline Somatic indices & $\begin{array}{l}\text { The relative mass of some } \\
\text { organs is often indicative of } \\
\text { chemical exposure }\end{array}$ & $\begin{array}{l}\text { Gonads, spleen, } \\
\text { liver }\end{array}$ & $\begin{array}{l}\text { Overall organism } \\
\text { health }\end{array}$ & Grady and others (1992) \\
\hline $\begin{array}{l}\text { Necropsy-based fish } \\
\text { health } \\
\text { assessment }\end{array}$ & $\begin{array}{l}\text { Visual assessment of } \\
\text { external/internal anomalies (for } \\
\text { example, lesions, parasites, } \\
\text { tumors), which may indicate } \\
\text { contaminant-related stress }\end{array}$ & All & $\begin{array}{l}\text { Overall organism } \\
\text { health }\end{array}$ & $\begin{array}{l}\text { Goede }(1988 ; 1996) ; \\
\text { Adams and others }(1993) ; \\
\text { Adams (1990) }\end{array}$ \\
\hline
\end{tabular}

the maximum amount of information on accumulative contaminants of potential concern at minimal cost, and to maintain continuity with the NCBP and BEST databases (Schmitt, 2002a; Schmitt and others, 1999b). Extracts of the composite samples were screened with the H4IIE rat hepatoma cell bioassay (Whyte and others, 2004), which responds to planar PHHs (Table 4). In addition, the livers of the individual fish were assayed for ethoxyresorufin $O$-deethylase (EROD) activity, which indicates recent exposure to exogenous AhR ligands including PHH and PAH (Whyte and others, 2000). Together, these assays and analyses allow estimation of the relative concentrations and potential biological effects of PHH and PAH (Table 4) without the expense of instrumental analyses for these compounds (Schmitt and others, 2002c).

Measures of fish health at various levels of biological organization, immune system responses, and reproductive sta- tus were included in the suite of indicators to address potential impacts from non-accumulative contaminants and contaminant mixtures (Table 2). Fish health measures included: (1) gross observations for abnormalities; (2) condition and organosomatic indices; and (3) histopathological examination. Gross observation and determination of indices based on relative fish and organ sizes such as the condition factor (CF), hepatosomatic index (HSI), and splenosomatic index (SSI) are relatively simple and indicative of cumulative, organism-level changes. However, they are non-specific in terms of causal mechanisms and may be transient. Histopathologic changes are more complex but may reflect early, subtle alterations and may foreshadow subsequent effects at the individual organism or population levels.

In addition to being an indicator of overall organism health the SSI is also an indicator of immune system stress 


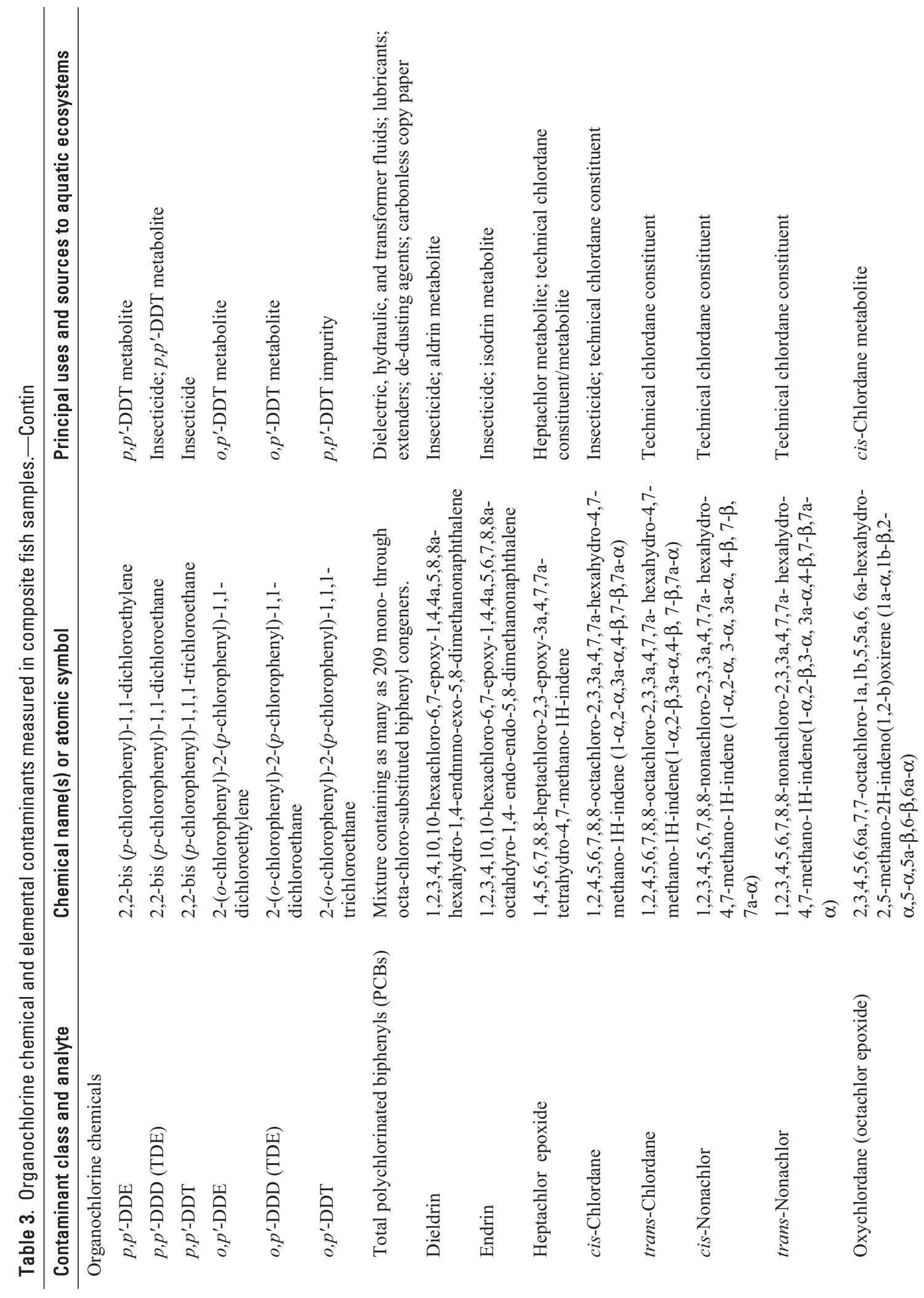




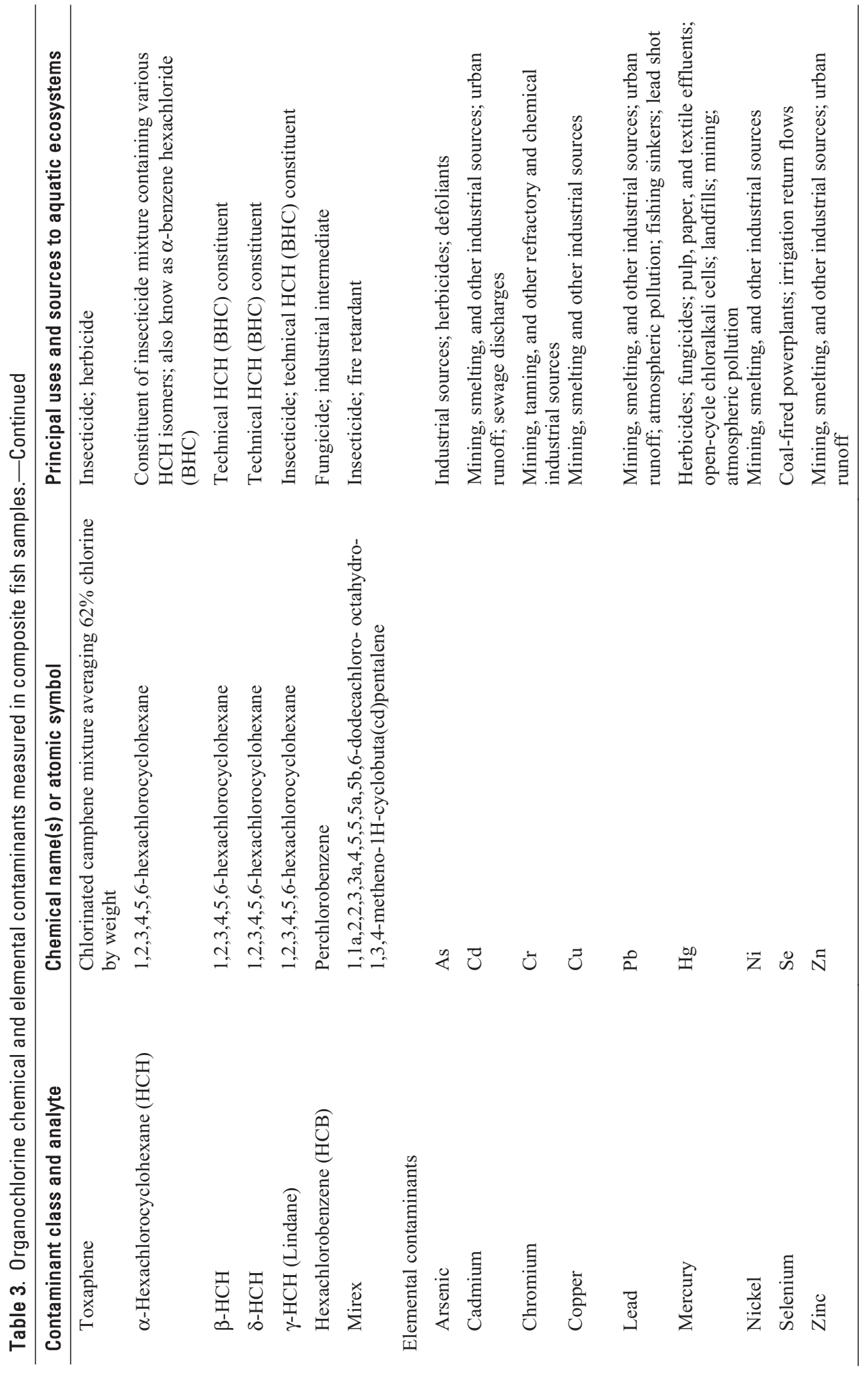


Table 4. Monitoring and assessment strategy for polycyclic aromatic and polyhalogenated hydrocarbons (PAHs and PHHs). aTotal PCBs were determined by gas chromatography with electron-capture detection. ${ }^{\text {b}} 7$-ethoxyresorufin 0 -deethylase. ${ }^{\mathrm{C}} \mathrm{H} 4 \mathrm{IIE}$ bioassay was performed after reactive cleanup to remove AhRactive PAHs. ${ }^{\mathrm{d} A n d}$ other planar organic compounds. + responds; - does not respond; *AhR-active isomers and congeners only.

\begin{tabular}{|c|c|c|c|}
\hline \multirow[b]{2}{*}{ Endpoint } & \multicolumn{3}{|c|}{ Contaminants } \\
\hline & PCBs & $\begin{array}{l}\text { PCDDs \& } \\
\text { PCDFs }\end{array}$ & $\mathrm{PAHs}^{\mathrm{d}}$ \\
\hline GC-ECD ${ }^{a}$ (carcass) & + & - & - \\
\hline EROD activity ${ }^{\mathrm{b}}$ (liver) & $*$ & * & $*$ \\
\hline H4IIE bioassay ${ }^{c}$ (carcass) & * & * & - \\
\hline
\end{tabular}

(Blazer and Dethloff, 2000). Other immune system indicators included the measurement of macrophage aggregates (MA) in preserved samples of spleen tissue (Table 2). Macrophage aggregates, also known as melanomacrophage centers, are discrete aggregations of pigment-bearing macrophages found in the spleen, kidney, and sometimes liver of advanced teleosts (Agius, 1980; Blazer and Dethloff, 2000). These specialized cells are thought to be responsible for centralizing foreign material and debris for destruction, detoxification or reuse; storing waste products; contributing to the immune response; and storing and recycling iron (Ellis and others, 1976; Ferguson, 1976). Although they may be affected by many factors, MA measurements have responded to contaminant exposure in both field and laboratory studies [reviewed by Wolke (1992) and Blazer and others (1997)].

Measures of reproductive condition included plasma vitellogenin (vtg) concentrations, gonadosomatic index (GSI), and gonadal histopathology [Table 2; see also review by McDonald and others (2000)]. Although reproductive condition in fish can be influenced by many factors (for example gender, age, reproductive stage, season, water temperature), contaminants, particularly estrogen mimics, have been shown to impact fish reproduction in laboratory and field studies (Allen and others, 1999; Gimeno and others, 1998). Estrogen mimics are theoretically capable of stimulating the production of vtg, a precursor of yolk protein, in the livers of oviparous vertebrates. A variety of endocrine disrupting compounds have been shown to induce vitellogenesis (Servos, 1999; Tyler and others, 1998). Vitellogenin production is normally associated with female fish; however, vtg may also be present in the plasma of male fish, and the detection of levels typical of early- to mid-vitellogenic females in male fish has been associated with exposure to exogenous estrogens (Bowman and others, 2002; Folmar and others, 1996; Folmar and others, 2001). To document these and other possible reproductive alterations and to define baseline concentrations, vtg was measured in both male and female fish. Gonadal histopathology [gonadal stage, presence of atretic oocytes, intersex conditions (presence of female reproductive tissue in males or viceversa), and presence of pigmented cellular accumulations] and GSI were also assessed as measures of reproductive health and status (Schmitt and others, 2002b). The GSI relates the proportional size of the gonad to body mass and may reflect changes resulting from a variety of physiological factors such as reproductive stage and environmental stressors, the latter including exposure to contaminants. Elevated occurrences of atretic (unfertilized and/or reabsorbed) eggs have been noted in fish exposed to contaminants (Cross and Hose, 1988; Johnson and others, 1988), although other factors may also be involved (June 1970; 1977). Feminization of male fish (that is, intersex condition) has been reported in laboratory and field studies of contaminants (Allen and others, 1999; Gimeno and others, 1998; 1997; Jobling and others, 1998). The accumulation of ceroid and lipofuschin pigments, which are oxidation products of lipids, in the spleen and liver is considered evidence of oxidative stress and sublethal cellular injury (Blazer, 2002; Vogelbein, 1993).

\section{Field Procedures}

\section{Fish Collection}

Fish were collected by DC electrofishing from a boat, with the following exceptions: gill nets were used at Station 63 to capture smallmouth bass (Micropterus dolomieu); trammel nets were used at Station 65; blue catfish (Ictalurus furcatus) were captured by hand at Station 515; and hoop nets were used at Station 511 due to high salinity, which precluded electrofishing. When possible, these alternative methods were avoided to minimize bias resulting from differing collection methods. Collection was generally conducted along the shoreline or in backwater areas of the river or reservoir being sampled. Because electrofishing tends to be biased toward larger fish (Reynolds, 1983), all specimens of the target species were collected, irrespective of size. Those within the desired size range were kept and the rest were released. At some sites samples representing more than 10 fish of a given species and gender were collected. GPS coordinates were recorded at the upstream and downstream extents of the area from which fish were collected (Table 1). Fish were held on-board in live wells and transported to shore for processing, usually within a few hours of collection. At some stations, fish were held alive overnight in net pens or in aerated tanks containing ambient water following night collections.

\section{Sample Processing}

The methods used to process the fish have been fully described (Schmitt, 2002a; Schmitt and others, 1999a; Schmitt and Dethloff, 2000). Briefly, a live fish was selected for processing and identified to species. A blood sample was collected from the posterior caudal artery and vein with a heparinized needle and syringe and placed on [wet] ice; from this sample, plasma was later obtained for determination of vtg 
concentration. The fish was weighed, measured, and subdued. Observations of external features were recorded, and grossly visible anomalies were removed by dissection and preserved in $10 \%$ neutral buffered formalin for histopathological analysis. The abdominal cavity of the fish was dissected open and the liver (in species with a discrete liver), spleen, and gonads were removed and weighed. Liver weights for carp were not determined because this species has a dispersed hepatic organ. The liver, gall bladder, posterior and anterior kidneys, gonads, mesenteric fat (in certain species), and spleen were examined, and the gender of the fish was determined by gonadal observation. Pieces of liver were collected and immediately flashfrozen in a dry ice-ethanol slush, then transferred to a liquid nitrogen dry-shipper for storage and shipment; these samples were later analyzed for EROD activity. Samples of gonad, kidney, spleen, and additional pieces of liver were collected and preserved in $10 \%$ neutral buffered formalin for histopathological examination, gender confirmation (gonad), and macrophage aggregate analysis (spleen). Upon completion of the internal examination and dissection, scales (or spines from ictalurids) were collected for age determination. Remaining tissues (those not frozen or fixed) were placed back into the body cavity and the entire fish was wrapped in aluminum foil. The wrapped carcass was placed in a polyethylene bag with other carcasses of the same species and gender. These samples were chilled and later frozen for analysis of organochlorine chemical residues, elemental contaminants, and dioxin-like activity (with the H4IIE bioassay). The entire field procedure was typically conducted in 15-20 min (per fish), and tissue samples, especially liver for EROD analysis, were collected and frozen as rapidly as possible. Following the processing of the fish, blood samples were centrifuged and the plasma was aspirated and frozen in dry ice.

\section{Laboratory Analyses}

Composite fish samples were shipped frozen in dry ice to private laboratories that are managed through a contract overseen by the Patuxent Analytical Control Facility (PACF) of the USFWS. At the laboratories the samples were prepared and analyzed for organic and elemental contaminants. These laboratories also prepared the composite samples for H4IIE bioassay analyses. PACF oversaw quality assurance (QA) and quality control (QC) associated with these procedures. The H4IIE assays were conducted by the USGS Columbia Environmental Research Center, Columbia, Missouri (CERC). Additional information on sample preparation and chemical methods are presented by Schmitt and others (2002c), Schmitt (2002b), and Schmitt (2004). Cryogenically frozen liver samples for EROD analysis were also shipped (in dry shippers) to CERC for analysis. Cryogenically frozen plasma samples were similarly shipped to the Protein Chemistry Research Laboratory of the University of Florida, Gainesville, Florida (UF) for analysis of vtg. All preserved tissue samples were shipped to the National
Fish Health Laboratory of the USGS Leetown Science Center, Kearneysville, WV (LSC) for histopathological analysis. Information on these latter procedures are given by Blazer and others (2002) and McDonald and others (2002). Scales and spines were processed for age determination as described by Jearld (1983), with age (y) estimated from the number of completed annuli.

\section{Composite Sample Preparation}

Carcass samples were stored frozen $\left(-20^{\circ} \mathrm{C}\right)$ at the lead analytical laboratory (Lab 1) until they were processed. For processing, the carcass of each fish in the sample being prepared was sawed into pieces. The pieces of all the fish in the sample were then mixed and homogenized in a commercial meat grinder. One sub-sample $(100 \mathrm{~g})$ of the composite was re-frozen $\left(-20^{\circ} \mathrm{C}\right)$ and shipped frozen to Lab 2 for analysis of moisture content and elemental contaminants. A 10-g subsample was extracted with methylene chloride, subjected to the reactive cleanup procedure described in following sections, ampulated, and shipped to CERC for use in the H4IIE bioassay. Another 10-g subsample was retained by Lab 1 for analysis of organochlorine chemical residues by gas chromatography with electron capture detection (GC-ECD) and gravimetric determination of lipid content.

\section{Elemental Contaminants and Moisture Content}

At Lab 2 the 100-g sub-samples were freeze-dried; moisture content was determined by weight loss during lyophilization. Freeze-dried fish (25-50 g) was digested in nitric acid. Concentrations of total $\mathrm{As}, \mathrm{Pb}$, and $\mathrm{Se}$ in the digestates were determined by graphite furnace atomic absorption spectroscopy (AA). Concentrations of total $\mathrm{Hg}$ were determined by cold vapor AA. Concentrations of aluminum (Al), barium (Ba), beryllium (Be), boron (Bo), $\mathrm{Cd}, \mathrm{Cr}$, cobalt $(\mathrm{Co}), \mathrm{Cu}$, iron $(\mathrm{Fe})$, magnesium $(\mathrm{Mg})$, manganese $(\mathrm{Mn})$, molybdenum (Mo), Ni, silver (Ag), strontium ( $\mathrm{Sr}$ ), thallium (Th), vanadium $(\mathrm{V})$, and $\mathrm{Zn}$ were determined by inductively coupled plasma emission spectroscopy (ICPES) without pre-concentration. QA measures for elemental analyses included the analysis of reagent blanks, duplicate samples, certified reference materials, and fortified (spiked) samples (Table 5). These measures indicated minimal contamination in blanks that produced upward biases of $\leq 0.01 \mu \mathrm{g} / \mathrm{g}(\mathrm{dw})$ for all elements except $\mathrm{Zn}$ $(\leq 0.02 \mu \mathrm{g} / \mathrm{g})$, none of which would cause detectable additions to wet-weight concentrations reported here. Results for the other measures were also typical for the elements reported here and indicate that the analytical results accurately reflect true concentrations in the samples. Dry-weight limits-ofdetection (LODs) were determined individually for each analyte in each sample, but were nominally $5 \mu \mathrm{g} / \mathrm{g}$ for Al; $15 \mu \mathrm{g} / \mathrm{g}$ for $\mathrm{Fe}$ and $\mathrm{Mg}$; $0.1 \mu \mathrm{g} / \mathrm{g}$ for $\mathrm{Be}, \mathrm{Cd}$, and $\mathrm{Hg}$; $0.3 \mu \mathrm{g} / \mathrm{g}$ for $\mathrm{Sr}$; 
Table 5. Results of quality assurance (Q/A) analyses and limits-of-detection (LODs) for elemental contaminants.

\begin{tabular}{|c|c|c|c|c|c|c|c|c|c|}
\hline \multirow{2}{*}{ Q/A component } & \multicolumn{9}{|c|}{ Element } \\
\hline & As & $\mathrm{Cd}$ & $\mathrm{Cr}$ & $\mathrm{Cu}$ & $\mathrm{Hg}$ & $\mathrm{Ni}$ & $\mathrm{Pb}$ & $\mathrm{Se}$ & $\mathrm{Zn}$ \\
\hline \multicolumn{10}{|l|}{ Reagent blanks ${ }^{\mathrm{a}}(\mu \mathrm{g})$} \\
\hline Min. & 0 & 0 & 0 & 0 & 0 & 0 & 0 & 0 & 0.01 \\
\hline Max. & 0.04 & 0.05 & 0.25 & 0.25 & 0 & 0.25 & 0 & 0.20 & 0.50 \\
\hline Mean & 0.01 & 0.01 & 0.07 & 0.08 & 0 & 0.07 & 0 & 0.03 & 0.19 \\
\hline Max. addition $(\mu \mathrm{g} / \mathrm{g} \mathrm{dw})$ & 0.00 & 0.00 & 0.01 & 0.01 & 0 & 0.01 & 0 & 0.01 & 0.02 \\
\hline \multicolumn{10}{|l|}{ Duplicate analyses (\% diff.) } \\
\hline Min. & 0.20 & 0.20 & 1.00 & 1.10 & 0.08 & 5.48 & 0.40 & 2.32 & 0.23 \\
\hline Max. & 84.80 & 110.00 & 55.20 & 17.30 & 22.30 & 104.00 & 83.60 & 26.20 & 10.40 \\
\hline Mean & 26.10 & 17.90 & 21.32 & 7.94 & 8.03 & 35.85 & 20.72 & 8.44 & 4.75 \\
\hline \multicolumn{10}{|l|}{ Reference materials ${ }^{b c}$ (\% diff.) } \\
\hline Min. & 73.2 & 101.0 & 69.0 & 85.4 & 95.0 & 92.0 & 86.1 & 87.9 & 88.0 \\
\hline Max. & 107.0 & 135.0 & 137.0 & 103.0 & 122.0 & 136.0 & 128.0 & 111.0 & 130.0 \\
\hline Mean & 94.0 & 113.1 & 98.9 & 91.2 & 106.1 & 110.6 & 100.9 & 99.4 & 98.0 \\
\hline Cert. conc. $(\mu \mathrm{g} / \mathrm{g} \mathrm{dw})$ & 21.6 & 26.7 & 0.8 & 106.0 & 0.3 & 2.5 & 0.4 & 5.6 & 180.0 \\
\hline \multicolumn{10}{|l|}{ Fortified sample recoveries ${ }^{\mathrm{b}}(\%)$} \\
\hline Min. & 83.1 & 91.3 & 89.1 & 91.7 & 93.6 & 91.7 & 95.0 & 89.1 & 77.8 \\
\hline Max. & 122.0 & 115.0 & 111.0 & 114.0 & 124.0 & 112.0 & 114.0 & 106.0 & 129.0 \\
\hline Mean & 106.1 & 100.9 & 98.4 & 100.2 & 103.3 & 102.0 & 101.3 & 96.6 & 106.6 \\
\hline Nominal LOD $(\mu \mathrm{g} / \mathrm{g}$ dw) & 0.7 & 0.15 & 0.5 & 0.7 & 0.15 & 0.5 & 0.03 & 0.7 & 2.5 \\
\hline
\end{tabular}

$0.2 \mu \mathrm{g} / \mathrm{g}$ for $\mathrm{Pb} ; 0.5 \mu \mathrm{g} / \mathrm{g}$ for $\mathrm{As}, \mathrm{Ba}, \mathrm{Cr}, \mathrm{Cu}, \mathrm{Mo}, \mathrm{Ni}, \mathrm{Se}$, and $\mathrm{V} ; 2 \mu \mathrm{g} / \mathrm{g}$ for B; $1.5 \mu \mathrm{g} / \mathrm{g}$ for $\mathrm{Zn}$; and $0.5 \mu \mathrm{g} / \mathrm{g}$ for Mn (Table 5). These values, as well as the analytical results, were converted to wet-weight concentrations for statistical analysis and reporting. Additional information on the analyses of samples for elemental contaminants has been reported elsewhere (Schmitt, 2004; Schmitt and others, 2002c).

\section{Organochlorine Chemical Residues and Lipid Content}

At Lab 1, one 10-g subsample of each ground composite sample was mixed with anhydrous sodium sulfate and Soxhlet-extracted with hexane, concentrated by rotary evaporation, and dried to constant weight for gravimetric lipid determination. The concentrated lipid extracts were re-dissolved in petroleum ether and fractionated on Florisil ${ }^{\circledR}$ in two fractions. The first fraction, containing relatively polar organochlorine insecticides, was concentrated for quantification of residues by dual megabore-column GC-ECD. The second fraction was subjected to further concentration and column chromatography on silicic acid to separate HCB, mirex, and PCBs from other organochlorine pesticides. Each of these fractions were concentrated and analyzed by megabore-column GC-ECD, as described by Schmitt (2002b). Precision and accuracy of these determinations were ascertained through analyses of duplicates and fortified samples $(n=4)$, and residue identities were confirmed in selected samples. Recovery efficiency ranged from $60.2 \%$ for hexachlorobenzene (HCB) to $94.4 \%$ for mirex, but averaged $85-92 \%$ for most analytes (Table 6). Based on these results, the analyses were determined to accurately represent the true residue concentrations in the samples. The nominal LOD for individual compounds was $0.01 \mu \mathrm{g} / \mathrm{g}$ wetweight; for multi-component residues (toxaphene and PCBs) it was $0.05 \mu \mathrm{g} / \mathrm{g}$ (Table 6). Residue concentrations were not adjusted for recovery efficiency. Additional information on the organic analyses has been reported elsewhere (Schmitt, 2002b; Schmitt and others, 2002c).

\section{H4IIE Rat Hepatoma Cell Bioassay}

The 10-g sub-samples for H4IIE analysis were kept frozen at Lab 1 until the initiation of sample processing, full details of which can be found in Schmitt and others (2002c). 
Table 6. Results of quality assurance ( $Q / A)$ analyses and nominal limits of detection (LODs) for organochlorine chemical residues. All results in \% unless otherwise indicated (ND, not determined).

\begin{tabular}{|c|c|c|c|c|c|c|c|}
\hline \multirow[b]{2}{*}{ Analyte } & \multicolumn{3}{|c|}{ Fortified sample recoveries } & \multicolumn{3}{|c|}{ Duplicate analyses } & \multirow{2}{*}{$\begin{array}{l}\text { LOD } \\
(\mu \mathrm{g} / \mathrm{g})\end{array}$} \\
\hline & Min. & Max. & Mean & Min. & Max. & Mean & \\
\hline Lipid & ND & ND & ND & 0.4 & 8.9 & 4.6 & ND \\
\hline Moisture & ND & ND & ND & 0.7 & 2.6 & 1.5 & ND \\
\hline$o, p^{\prime}-\mathrm{DDD}$ & 82.5 & 96 & 90.8 & 0 & 0 & 0 & 0.01 \\
\hline$o, p^{\prime}-\mathrm{DDE}$ & 84.0 & 93.5 & 90.4 & 0 & 0 & 0 & 0.01 \\
\hline$o, p^{\prime}$-DDT & 80.0 & 88.5 & 84.4 & 0 & 0 & 0 & 0.01 \\
\hline$p, p^{\prime}-\mathrm{DDD}$ & 81.0 & 94.0 & 86.4 & 0 & 29.3 & 14.0 & 0.01 \\
\hline$p, p^{\prime}-\mathrm{DDE}$ & 80.0 & 90.0 & 84.4 & 0 & 7.8 & 4.0 & 0.01 \\
\hline$p, p^{\prime}-\mathrm{DDT}$ & 80.0 & 91.0 & 85.9 & 0 & 0 & 0 & 0.01 \\
\hline cis-Chlordane & 82.5 & 92.5 & 88.8 & 0 & 0 & 0 & 0.01 \\
\hline trans Chlordane & 82.0 & 91.5 & 87.4 & 0 & 0 & 0 & 0.01 \\
\hline cis-Nonachlor & 80.0 & 88.5 & 86.2 & 0 & 0 & 0 & 0.01 \\
\hline trans-Nonachlor & 84.0 & 92.0 & 88.0 & 0 & 7.7 & 1.9 & 0.01 \\
\hline Oxychlordane & 82.5 & 90.0 & 87.0 & 0 & 0 & 0 & 0.01 \\
\hline Heptachlor epoxide & 81.0 & 90.0 & 85.9 & 0 & 0 & 0 & 0.01 \\
\hline Dieldrin & 87.0 & 102.0 & 93.8 & 0 & 0 & 0 & 0.01 \\
\hline Endrin & 85.0 & 98.0 & 89.9 & 0 & 0 & 0 & 0.01 \\
\hline HCB & 64.0 & 83.0 & 74.3 & 0 & 0 & 0 & 0.01 \\
\hline Mirex & 90.0 & 96.5 & 94.4 & 0 & 0 & 0 & 0.01 \\
\hline$\alpha-\mathrm{BHC}$ & 74.5 & 87.0 & 82.6 & 0 & 0 & 0 & 0.01 \\
\hline$\beta-\mathrm{BHC}$ & 84.5 & 98.0 & 90.0 & 0 & 0 & 0 & 0.01 \\
\hline$\gamma-\mathrm{BHC}$ & 77.5 & 86.5 & 83.5 & 0 & 0 & 0 & 0.01 \\
\hline$\delta$-BHC & 81.5 & 91.0 & 84.4 & 0 & 0 & 0 & 0.01 \\
\hline Toxaphene $^{\mathrm{a}}$ & ND & ND & ND & 0 & 0 & 0 & 0.05 \\
\hline Total PCBs ${ }^{b}$ & ND & ND & ND & ND & ND & ND & 0.05 \\
\hline
\end{tabular}

Briefly, samples were thawed, homogenized, and columnextracted with methylene chloride. Percent lipid was determined on a $1 \%$ portion of the extract. The remainder was concentrated and cleaned up by two-stage column chromatography. Extracts were evaporated, re-dissolved with isooctane, ampulated, and shipped to the CERC for analysis. Matrix QC samples (blanks and spikes) prepared at Lab 1 and at the CERC included ground tissues from laboratory-raised bluegill (Lepomis macrochirus) and samples of a CERC standard positive control tissue (carp from Saginaw Bay, Michigan). These QC samples were processed concurrently with the 1997 samples.

At CERC, the H4IIE bioassay was performed on the composite sample extracts according to the method of Tillitt and others (1991) as modified for 96-well microtiter plates (Tysklind and others, 1994) and described by Birke and Tillitt (2000a). The H4IIE cells were seeded at 7000 cells/well in $300 \mu \mathrm{L}$ of D-MEM culture media (Tillitt and others, 1991). After a 24-h incubation, the cells were dosed with sample extracts or standards in isooctane as described in Schmitt and others (2002c). At least three 2,3,7,8-tetrachlorodibenzo$p$-dioxin (TCDD) curves were analyzed each day. A linear regression was performed on the data from each well to determine an EROD rate ( $\mathrm{pmol} / \mathrm{min})$. The amount of protein in each well was determined by the fluorescamine assay (Lorenzen and Kennedy, 1993) and the values used to normalize dose to each well and EROD activity. The doses of each sample (g-equivalents/mg cellular protein) or TCDD standards (pg TCDD/mg of cellular protein) were plotted against EROD activity (pmol of resorufin/min/mg cellular protein, henceforth $\mathrm{pmol} / \mathrm{min} / \mathrm{mg}$ ) to develop dose-response curves. The linear portions of these curves were used to compare the relative 
potencies of the extracts with that of the TCDD standard. The determination of TCDD-equivalents (TCDD-EQ) was by slope ratio assay (Finney 1980) as described by Ankley and others (1991). Variance estimates were based on an additive model (Finney 1980) and were calculated as described previously (Ankley and others, 1991; Tillitt and others, 1991).

QA procedures and results are documented in Birke and Tillitt (2000a). Samples were analyzed in blocks of about 40. Limits-of-quantitation (LOQs) and LODs were computed separately for each block; LODs were $0-1 \mathrm{pg} / \mathrm{g}$ and all LOQs were $1 \mathrm{pg} / \mathrm{g}$ (rounded to the nearest whole number). The results of the QA program indicated that the bioassays accurately reflected the dioxin-like potency of the extracts (Birke and Tillitt, 2000a).

\section{EROD Activity}

Cryogenically frozen liver samples were stored at $-80^{\circ}$ $\mathrm{C}$ until the preparation of microsomal fractions. The kinetic microsomal assays were conducted in 96-well microtiter plates; microsomal preparations were used the day they were prepared. The procedures are fully described elsewhere (Birke and Tillitt, 2000a; Schmitt and others, 2002c). Briefly, triplicate determinations of EROD activity were performed on $5-\mu \mathrm{L}$ portions of each microsomal preparation; mean EROD activity was reported. Protein content was determined using the fluorescamine protein assay (Lorenzen and Kennedy, 1993) in the same 96-well microtiter plate as the EROD analyses. A positive control material [liver microsomes from laboratory-raised channel catfish injected with $10 \mathrm{mg} / \mathrm{kg}$ of benzo(a)pyrene] and an additional reference material [liver microsomes of flathead catfish (Pylodictis olivaris) obtained from the Missouri River near Easley, Missouri] were also analyzed. A linear regression was performed on the data from each well to determine an EROD rate (pmol/min) and associated variance. The amount of protein was used to normalize EROD activity in each well; results were reported in units of $\mathrm{pmol} / \mathrm{min} / \mathrm{mg}$. A rigorous QA program was followed for the EROD assays, as described in Birke and Tillitt (2000b). LODs ranged from 0 to 0.147 $\mathrm{pmol} / \mathrm{min} / \mathrm{mg}$ whereas LOQs ranged from 0 to $0.35 \mathrm{pmol} / \mathrm{min} /$ $\mathrm{mg}$. The results of this QA program indicated that the assays accurately reflected the hepatic EROD rates of the samples analyzed.

\section{Fish Health Indicators}

\section{General Histopathological Analyses}

Fixed tissues (liver, kidney, spleen, gill, gonad, and grossly visible lesions) were shipped to the LSC and prepared for routine histopathological analysis as described by Blazer and others (2002). Paraffin-embedded tissue sections (6- $\mu \mathrm{m})$ mounted on glass slides were stained with hematoxylin and eosin (H \& E) for microscopic examination.

\section{Macrophage Aggregates}

Macrophage aggregates and MA pigments in spleen sections were stained using Perl's method (Luna, 1992). Using this method, melanin (a melanosome pigment derived from tyrosine metabolism) is black; hemosiderin, which is a protein-bound iron pigment, stains blue; and ceroid/lipofuscin, which are lipogenic pigments arising from the oxidation of unsaturated lipids, are yellow-tan. All MA measurements were made with a computer-based image analysis system, and included the number of aggregates in $2 \mathrm{~mm}^{2}$ of tissue (MAMM) and the mean area occupied by those aggregates (MEANAREA). The percentage of tissue occupied by MA (TISSOC) was computed from these measurements.

\section{Quantitative Organism-Level Indicators}

The prevalence of gross external pathological disorders was determined with a rating of present (1) or not present (0) deduced from the field data. For consistency with other monitoring programs that have used this type of assessment [for example, Fournie and others, 1996], only certain observations were included (Blazer and others, 2002). Included were grossly visible disorders of the eye (exopthalmia, hemorrhage, opacity, emboli, missing), opercles (shortening, deformities, parasites), and body surface (ulcers, parasites, and raised or discolored areas). Disorders of the fins (hemorrhage, fraying, and so forth) and skeleton (curvature) were also included. Numerical values were assigned to internal and external observations of lesions recorded in the field, and a necropsybased fish health assessment (HAI) score was calculated for each fish by summing these values for all organs (Blazer and others, 2002). A value was only computed for a fish if there were observations for all components.

Body and organ weights measured in the field were used to compute condition factor (CF) and organosomatic indices (Blazer and others, 2002; Dethloff and Schmitt, 2000) according to the following formulae: $\mathrm{CF}=$ body weight/length ${ }^{3}$; HSI = liver weight/(total body weight - gonad weight) X 100; and $\mathrm{SSI}=$ spleen weight/(total body weight - gonad weight) $\mathrm{X}$ 100. The weight of the gonads was subtracted from the body weight in the computation of HSI and SSI to minimize the effect of the reproductive cycle on these indices (Dethloff and Schmitt, 2000). GSI was calculated as GSI = gonad weight/ total body weight X 100 . 


\section{Reproductive Indicators}

\section{Gonadal Histopathology}

The posterior tip of the gonad was dissected in the field and fixed immediately in 10\% neutral buffered formalin. Transverse sections were processed for routine light microscopy (embedded in paraffin, sectioned at $6 \mu \mathrm{m}$, and stained with $\mathrm{H} \& \mathrm{E})$.

Female gonadal tissue was staged using developmental stages (designated 0-5) to classify each section (Blazer, 2002; McDonald and others, 2000; Nagahama, 1983; Rodriguez and others, 1995; Treasurer and Holliday, 1981). Carp and bass ovaries typically contain oocytes in several developmental stages and were therefore classified according to the maturity of the predominant stage of oogenesis of each tissue sample. Ovaries containing only previtellogenic chromatin nucleoli and perinuclear oocytes, which were identified by cytoplasm that stained basophilic with $\mathrm{H} \& \mathrm{E}$, were assigned to stage 0 . Those containing many oocytes with cortical alveoli in addition to the previtellogenic chromatin nucleoli and perinuclear oocytes characteristic of stage 0 were assigned to stage 1 . Ovaries containing primarily oocytes with cortical alveoli and yolk globules filling the cytoplasm were classified as stage 2 (early vitellogenic), whereas those containing larger oocytes in which the cortical alveoli were pushed to the periphery of cell, yolk globules filled the center, and the chorion of the developing oocytes were thicker than in earlier stages were designated as stage 3 (mid-vitellogenic). Ovaries containing oocytes with fused yolk globules that appear as a homogenous mass were designated as stage 4 (mature). Ovaries containing post-ovulatory follicles, which can be observed for some time after ovulation, are typically assigned to stage 5 (spent); none were observed, however. After the ovarian tissue samples were staged they were further examined by light microscopy for atresia and other conditions such as pigment cell accumulations, parasites, and neoplastic changes. One hundred oocytes in each sample were counted when possible; those showing morphological evidence of resorption or necrosis were quantified, and the percentage of atretic oocytes was calculated.

Analogous to the procedure used to stage ovaries, male gonadal tissue was classified into five developmental stages $(0-4)$ according to the maturity of the predominant stage of spermatogenesis of each tissue sample(Blazer, 2002; Nagahama, 1983; Schmitt and others, 2002b). Immature, undeveloped, or regressed testes containing only spermatogonia were classified as stage 0 (immature) whereas those containing primarily spermatocytes and spermatids were designated as stage 1 (early spermatogenic). Mid-spermatogenic (stage 2) testes containing approximately equal proportions of spermatocytes, spermatids, and spermatozoa were classified as stage 2 (midspermatogenic), and those containing primarily mature spermatozoa were classified as stage 3 (late spermatogenic). Stage 4 (post-spawning or spent) males were not observed. Testicu- lar tissue was also examined microscopically for any abnormalities such as intersex, parasites, neoplasia, and pigmented cell accumulations. Male fish were classified as intersex when individual or small foci of undeveloped oocytes were observed within testicular tissue (that is, when an ovotestis condition was detected).

Pigmented cell accumulations contain ceroid or lipofuscin pigments derived from the oxidation of lipids, which may be indicative of oxidative stress. They are visible in histologic sections of ovaries and testes as yellowish-brown deposits. The amount of ceroid pigment observed in each sample was rated on a scale of 0 (no pigment) to 4 (heavily pigmented).

\section{Vitellogenin}

A sandwich ELISA was used to determine vtg concentrations in plasma samples obtained from largemouth bass, smallmouth bass, and carp (Denslow and others, 1999). Wells of a microtiter plate were saturated with $10 \mu \mathrm{g} / \mathrm{mL}$ of monoclonal antibodies developed specifically against bass (3G2) and carp (2D4) vtg in phosphate-buffered saline $(50 \mu \mathrm{L} /$ well $)$. Plates were incubated overnight, then washed with Tris-buffered saline-Tween (TBST). Blocking reagent (10\% BSA in TBST, $360 \mu \mathrm{L} /$ well) was added to each well and allowed to incubate for $2 \mathrm{~h}$. Plates were washed with TBST and $50 \mu \mathrm{L}$ of standard or samples were added and incubated overnight. Unknown plasma samples were diluted from 1:100 (bass) to 1:500 (carp) in $1 \%$ BSA-TBST containing $10 \mathrm{kIU} / \mathrm{mL}$ of Aprotinin as protease inhibitor. Standard curves were prepared by diluting purified vtg in diluted plasma from control male fish of the same species tested. After overnight incubation, plates were washed with TBST and $50 \mu \mathrm{L}$ of 1:1000 rabbit polyclonal antiserum in 1\% BSA-TBST was added to each well. After a 2-h incubation, plates were washed and $50 \mu \mathrm{L}$ of goat anti-rabbit $\mathrm{F}(\mathrm{ab}) 2$ alkaline phosphatase conjugate in $1 \%$ BSA-TBST was added to each well as the secondary antibody. After incubation for $2 \mathrm{~h}$, plates were washed and $100 \mu \mathrm{L}$ of substrate was added to each well and incubated for $30 \mathrm{~min}$. The reaction was stopped by addition of $50 \mu \mathrm{L} /$ well of $3 \mathrm{~N} \mathrm{NaOH}$. Plates were read at $405 \mathrm{~nm}$ in an automated microtiter plate reader (Spectromax Pro, Applied Biosystems). Concentrations of the unknowns were determined from the standard curves. The LOD was $0.002 \mathrm{mg} / \mathrm{mL}$ of plasma for bass and 0.005 $\mathrm{mg} / \mathrm{mL}$ for carp. All assays were performed in triplicate and reported as the mean of the three measurements. The coefficient of variation was $<10 \%$ for all samples analyzed. Interassay variability was routinely measured by analyzing controls on several plates and was found to be $<10 \%$.

\section{Data Set Composition and Statistical Analyses}

Species were grouped into larger taxon groupings for analysis. These included carp, bass (largemouth and small- 
mouth bass), Morone sp. [white bass (M. chrysops) and striped bass (M. saxatilis)], catfish [channel catfish and blue catfish], and northern pike (Esox lucius). For indicators based on individual fish (that is, biomarkers and demographic endpoints), data are discussed in terms of the magnitudes of the means or medians for combined stages or each stage within a gender for different species or taxon grouping. Data were graphically summarized with box plots presenting the mean, range, median, and $25^{\text {th }}$ and $75^{\text {th }}$ percentiles. Some biomarker results were also analyzed more rigorously (see following sections). For statistical testing, transformations were applied as necessary to achieve the normality and homogeneity-of-variance required for the application of parametric statistical methods. Because the RGB data set is relatively small, the transformations applied were those used in the analysis of the much more extensive 1995 MRB data set (Schmitt, 2002a). The length, weight, and age data were not transformed. Concentrations of contaminants and TCDD-EQ in composite samples, as well as EROD activities and vtg concentrations in individual fish, were log-transformed (only vtg in female fish was analyzed statistically). HAI scores were rank-transformed. Raw data can be obtained at <http://www.cerc.usgs.gov/data/data.htm>.

Descriptive statistics (arithmetic mean, minimum, maximum, and standard error) were computed for length, weight and age data for species and taxon groupings at each station. Fish from which only regenerated scales were collected (24 fish; 22 carp, one largemouth bass, and one northern pike) were reported as ND (not determined) and excluded from the analysis and interpretation of age data and all analyses that included age as a factor. Fish for which the field gender identification could not be verified histologically (including four fish of the targeted species) were reported as NG (no gonad) and likewise excluded from analyses that included gender as a factor. Data for carp and bass were summarized and discussed in more detail than other species. Because of the influence of fish size on $\mathrm{Hg}$ concentrations in predatory fish, length and weights of bass were also analyzed statistically (see next section). Length and weight data for all other species are presented only in tabular form.

All results for composite samples were converted to, analyzed statistically as, and reported as wet-weight concentrations. A value of one-half the LOD was substituted for censored values in the computation of un-weighted geometric station means, for statistical analyses, and for graphing. Concentrations of many contaminants were below detection limits, which limited the extent and rigor of the statistical analyses that could be performed. All composite sample data (tissue concentrations and H4IIE results) are presented graphically and as tabular summaries. For $p, p$ '-DDE, $\mathrm{As}, \mathrm{Cd}, \mathrm{Cu}, \mathrm{Hg}, \mathrm{Pb}$, $\mathrm{Se}$, and $\mathrm{Zn}$, temporal and geographic differences were also examined statistically using ANOVA. For these analyses, logtransformed concentrations in carp, bass, catfish, and Morone sp. were combined with historical data for these taxa (Schmitt and others, 1999b) representing the four NCBP stations (16, 63,65 , and 65) in the RGB. These data were analyzed as a one-way ANOVA in which samples representing stations, col- lection years, and taxa were grouped into 113 unique combinations ("treatments"). Selected pair-wise comparisons of leastsquares treatment means representing 1997 concentrations contrasted against previous years within each station-taxon combination were then conducted using Fischer's protected LSD. Treatments representing the 1997 station-taxon means were also compared as part of this analysis. These single degree-of-freedom, non-orthogonal contrasts used the pooled error mean-square $\left(\mathrm{MS}_{\mathrm{e}}\right.$ ) to evaluate differences between- or among-samples representing the same taxon. A nominal $\alpha$ level of 0.01 was used in these comparisons to protect against experiment-wise error. Because concentrations of $\mathrm{Hg}$ in predatory fish increase with size, age, or both [see for example (Wiener and others, 2002)], log-transformed length-adjusted $(\mathrm{HgL})$ and weight-adjusted $(\mathrm{HgW})$ concentrations were also tested using this procedure. Following the method of Brumbaugh and others (2001), the length- and weight-adjusted values were computed by dividing the measured $\mathrm{Hg}$ concentration in each composite sample by the mean length $(\mathrm{m})$ and weight $(\mathrm{kg})$ of the individual fish in the sample. Brumbaugh and others (2001) also analyzed age-adjusted concentrations; however, age-adjustment could not be performed because there were substantial numbers of re-generated scales among the fish from some sites. Because these fish could not be aged, the mean age of many composite samples could not be estimated. In addition, the NCBP fish collected historically were not aged; however, the mean lengths and weights of the fish comprising the composite samples were reported. Length, weight, $\mathrm{Hg}, \mathrm{HgW}$, and $\mathrm{HgL}$ were also analyzed separately for bass using the one-way analysis. This resulted in a more conservative test with only 16 treatments, fewer degrees-of-freedom, and $\mathrm{MS}_{\mathrm{e}}$-values based on only one taxon. These latter analyses were not performed for other contaminants because the relationships between fish size and concentration are not as well documented.

Many biomarkers differ among species, gender, and reproductive stages (Schmitt, 2002a; Schmitt and Dethloff, 2000). Accordingly, and using the analyses conducted on the larger 1995 MRB data set as a guide (Schmitt, 2002a), a series of linear ANOVA models were fit to the individual fish data for carp and bass to determine the influence of selected factors on biomarker responses in these taxa. In these models, station and gender were treated as class variables and age and stage were considered continuous variables; the models included both main effects and interactions. The results of these analyses were reported as $F$-values and significance levels and were used to guide the graphical presentation and discussion of the findings; however, because of the complexity of the models relative to the small size of the data set, most means were not adjusted for the factors in the models. The exception was the MA variables; because of the known increase in MA density (MAMM) over time (Blazer and others, 2002), the MA data were re-analyzed with a model that included age, and ageadjusted station means for MA parameters in carp and bass were estimated based on data from fish that could be aged. 
Results are generally presented and discussed in terms of the magnitudes of the means or medians either for combined genders or for each gender within a species or taxon grouping and at different stations within a species or taxon grouping. Where appropriate, data were also grouped and reported by gonadal stage or age.

Correlations between biomarker results and concentrations of selected contaminants in carp and bass were also examined. For these analyses, mean biomarker responses in the individual fish comprised by each composite sample were combined with contaminant data for that sample. Spearman rank correlations, which are not affected by deviation from normality, were computed for samples representing male and female carp and bass (together and combined within taxon) and for catfish.

\section{Results and Discussion}

\section{Geographic Distribution and Demographic Characteristics of the Fish Samples}

A total of 368 fish representing eight species were collected at the ten stations sampled (Table 7). Carp and bass accounted for $77 \%$ of the fish collected. Of the remaining five species, only channel catfish accounted for more than $10 \%$ of the total (Table 7). Carp were obtained at all 10 stations, largemouth bass were obtained at five stations, and the remaining species were obtained at one or two stations (Table 7; Appendix Table 2). Only three smallmouth bass were collected; two females at Station 63 and one male at Station 514 (Table 7; Appendix Table 2). Alternate predator species (northern pike, white bass, blue and channel catfish) were collected at the stations from which bass could not be obtained.
Size and count data for non-target species are summarized in Appendix Tables 2 and 3.

The mean total length (TL) of carp from the RGB was $531 \mathrm{~mm}$ (range 294-854 g) and the mean weight was $2355 \mathrm{~g}$ (range 325-9000 g) (Table 8). The mean age for all carp was 3.2 y (range 1-8 y). On average, females outweighed males (2537 vs. $2131 \mathrm{~g}$ ) and were longer (542 vs. $518 \mathrm{~mm}$ ) but the mean ages of males and females were approximately equal (3.1 vs. 3.2 y). The largest male and female carp (mean TL and weight) were collected from Stations 515, 514, and 513 (largest to smallest); the smallest were from Station 65 (Table 8). Female carp were youngest on average at Stations 64 and 516 and oldest at Station 63 whereas males were youngest at Station 514 and oldest at Station 513. Mean age was not consistently related to mean size; that is, the oldest carp were not necessarily the largest, indicating growth rate differences among stations (Table 8). Overall, the average lengths, weights, and ages of carp from the RGB were similar to those obtained from the MRB in 1995 (Schmitt and others, 2002b), but the ranges were smaller.

A total of 75 bass (72 largemouth, three smallmouth) were collected at five RGB stations (Table 9). The smallmouth bass were within the size ranges of the largemouth bass at the two stations (63 and 514) where they were collected. Overall, bass averaged $364 \mathrm{~mm}$ in TL (range 218-614 mm) and $843 \mathrm{~g}$ (range 149-4700 g; Table 9). The mean age for all bass was 1.8 y (range 0-5 y). On average, females outweighed males (1032 vs. $546 \mathrm{~g}$ ) and were longer (388 vs. $325 \mathrm{~mm}$ ) and older (2.1 vs. 1.3 y). Female bass were generally largest at Station 514 and smallest at Station 512 (Table 9). Male bass were, on average, smallest at Station 514 and largest at Station 16. Female mean age was lowest at Station 512 and highest at Station 63 whereas male mean age was lowest at Station 513 and highest at Station 16 (Table 9). As was true for carp, ranking of stations by mean age did not yield the same order as ranking by TL or weight, indicating growth rates differences among the stations. Overall, the bass from the RGB were similar in length and age to those obtained from the MRB in 1995 (Schmitt and others, 2002b); however, as was also true

Table 7. Fishes collected in the Rio Grande Basin (preferred species in bold).

\begin{tabular}{lccl}
\hline Species & No. fish & No. stations & Taxon grouping \\
\hline Common carp (Cyprinus carpio) & 207 & 10 & Carp \\
Blue catfish (Ictalurus furcatus) & 6 & 1 & Catfish (Ictalurus sp.) \\
Channel catfish (Ictalurus punctatus) & 42 & 2 & Catfish \\
Largemouth bass (Micropterus salmoides) & 72 & 5 & Bass (Micropterus sp.) \\
Smallmouth bass (Micropterus dolomieui) & 3 & 2 & Bass (Micropterus sp.) \\
Northern pike (Esox lucius) & 16 & 1 & Pike \\
Striped bass (Morone saxatilis) & 1 & 1 & Morone sp. \\
White bass (Morone americana) & 21 & 1 & Morone sp. \\
\hline
\end{tabular}


Table 8. Total lengths, weights, and ages of common carp collected in the Rio Grande Basin, by station and gender ( $M$, male; $F$, female; NG, no gonad sample obtained). Shown are arithmetic means, minima, and maxima. See Table 1 for station locations and collection dates.

\begin{tabular}{|c|c|c|c|c|c|c|c|c|c|}
\hline \multirow{2}{*}{$\begin{array}{l}\text { Station, } \\
\text { gender }\end{array}$} & \multicolumn{3}{|c|}{ Total length (mm) } & \multicolumn{3}{|c|}{ Weight (g) } & \multicolumn{3}{|c|}{ Age (y) } \\
\hline & No. fish & Mean & Range & No. fish & Mean & Range & No. fish & Mean & Range \\
\hline All & 206 & 531 & $294-854$ & 207 & 2355 & $325-9000$ & 184 & 3.2 & $1-8$ \\
\hline $\mathrm{F}$ & 113 & 542 & $321-854$ & 114 & 2537 & $450-9000$ & 98 & 3.1 & $1-8$ \\
\hline $\mathrm{M}$ & 92 & 518 & $294-673$ & 92 & 2131 & $325-6400$ & 85 & 3.2 & $1-8$ \\
\hline NG & 1 & 491 & -- & 1 & 1600 & -- & 1 & 3.0 & -- \\
\hline \multicolumn{10}{|l|}{16} \\
\hline $\mathrm{F}$ & 9 & 587 & $381-669$ & 10 & 2762 & $798-4190$ & 10 & 3.2 & $1-5$ \\
\hline M & 10 & 608 & $371-710$ & 10 & 3086 & $663-4400$ & 10 & 3.3 & $1-5$ \\
\hline \multicolumn{10}{|l|}{63} \\
\hline $\mathrm{F}$ & 15 & 493 & $459-589$ & 15 & 1343 & $1150-1800$ & 12 & 4.3 & $3-6$ \\
\hline M & 10 & 453 & $424-482$ & 10 & 1120 & $800-1500$ & 8 & 3.9 & $3-7$ \\
\hline \multicolumn{10}{|l|}{64} \\
\hline $\mathrm{F}$ & 23 & 496 & $426-571$ & 23 & 1870 & $1100-2800$ & 22 & 2.4 & $1-4$ \\
\hline M & 16 & 460 & $410-569$ & 16 & 1378 & $900-2600$ & 15 & 2.4 & $2-4$ \\
\hline NG & 1 & 491 & -- & 1 & 1600 & -- & 1 & 3.0 & -- \\
\hline \multicolumn{10}{|l|}{65} \\
\hline F & 10 & 365 & $321-461$ & 10 & 663 & $450-1225$ & 10 & 3.2 & $1-4$ \\
\hline M & 10 & 342 & $294-370$ & 10 & 493 & $325-650$ & 10 & 3.4 & $2-5$ \\
\hline \multicolumn{10}{|l|}{511} \\
\hline $\mathrm{F}$ & 13 & 533 & $400-734$ & 13 & 2046 & $737-4300$ & 10 & 3.4 & $2-5$ \\
\hline M & 7 & 454 & $365-520$ & 7 & 1259 & $628-1677$ & 7 & 4 & $3-5$ \\
\hline \multicolumn{10}{|l|}{512} \\
\hline F & 6 & 530 & $470-645$ & 6 & 1942 & $1500-3100$ & 6 & 3.5 & $1-6$ \\
\hline M & 8 & 551 & $480-635$ & 8 & 2013 & $1400-3200$ & 8 & 3.9 & $2-8$ \\
\hline \multicolumn{10}{|l|}{513} \\
\hline $\mathrm{F}$ & 11 & 601 & $417-854$ & 11 & 4242 & $1204-8900$ & 11 & 2.6 & $1-5$ \\
\hline M & 9 & 674 & $441-763$ & 9 & 4776 & $1481-6400$ & 8 & 4 & $1-8$ \\
\hline \multicolumn{10}{|l|}{514} \\
\hline F & 10 & 681 & $561-850$ & 10 & 5285 & $3400-9000$ & 8 & 3.4 & $1-8$ \\
\hline M & 10 & 593 & $551-706$ & 10 & 3110 & $2350-5300$ & 10 & 2.1 & $1-5$ \\
\hline \multicolumn{10}{|l|}{515} \\
\hline $\mathrm{F}$ & 6 & 694 & $627-820$ & 6 & 4250 & $3200-6500$ & 2 & 4 & $4-4$ \\
\hline M & 4 & 615 & $554-673$ & 4 & 3225 & $2500-4400$ & 2 & 3 & $2-4$ \\
\hline \multicolumn{10}{|l|}{516} \\
\hline $\mathrm{F}$ & 10 & 580 & $560-609$ & 10 & 2855 & $2500-3300$ & 7 & 2.4 & $1-5$ \\
\hline M & 8 & 526 & $353-606$ & 8 & 1956 & $600-2850$ & 7 & 3 & $2-5$ \\
\hline
\end{tabular}

for carp, the range was greater in the MRB, where a few older (but not larger) fish were sampled. Some RGB bass were heavier than any collected in 1995, indicating rapid growth at some sites. bass (one sample, one station), blue catfish (one sample, one station), and white bass (two samples, one station).

\section{Elemental Contaminants}

\section{Accumulative Contaminants, H4IIE Bioassay, and EROD Activity}

Composite samples $(n=47)$ from 10 stations were analyzed for organochlorine chemical residues, elemental contaminants, and TCDD-EQ by the H4IIE bioassay. Of these, 22 samples (47\%) from ten stations were carp and 12 samples (25.5\%) from five stations were bass. The remaining 13 samples (26\%) comprised channel catfish (five samples from two stations), northern pike (four samples, one station), striped

\section{Arsenic}

Concentrations of As exceeded detection limits (0.05$0.15 \mu \mathrm{g} / \mathrm{g})$ in 38 samples $(81 \%)$ representing all ten stations (Table 10). The greatest concentrations $(0.30-0.55 \mu \mathrm{g} / \mathrm{g})$ were in carp and white bass from Stations 65 and 514, in the middle RGB, and in largemouth bass from Station 512, in the lower RGB (Fig. 2). The maximum concentration was in male carp from Station 514 (Fig.2; Table 10). Elsewhere, concentrations in carp, channel catfish, white bass, and bass were 0.13-0.15 
Table 9. Total lengths, weights, and ages of bass (Micropterus spp.) collected in the Rio Grande Basin, by station and gender (M, male; F, female; NG, no gonad sample obtained). Shown are arithmetic means, minima, and maxima. See Table 1 for station locations and collection dates.

\begin{tabular}{|c|c|c|c|c|c|c|c|c|c|}
\hline \multirow{2}{*}{$\begin{array}{l}\text { Station, } \\
\text { gender }\end{array}$} & \multicolumn{3}{|c|}{ Total length (mm) } & \multicolumn{3}{|c|}{ Weight (g) } & \multicolumn{3}{|c|}{ Age (y) } \\
\hline & No. fish & Mean & Range & No. fish & Mean & Range & No. fish & Mean & Range \\
\hline All & 75 & 364 & $218-614$ & 75 & 843 & $149-4700$ & 74 & 1.8 & $0-5$ \\
\hline $\mathrm{F}$ & 42 & 388 & $218-614$ & 42 & 1032 & $149-4700$ & 41 & 2.1 & $0-5$ \\
\hline M & 30 & 325 & $229-456$ & 30 & 546 & $175-1165$ & 30 & 1.3 & $0-4$ \\
\hline NG & 3 & 402 & $340-474$ & 3 & 991 & $474-1600$ & 3 & 3.3 & $3-4$ \\
\hline \multicolumn{10}{|l|}{16} \\
\hline $\mathrm{F}$ & 11 & 404 & $332-546$ & 11 & 995 & $439-2700$ & 11 & 2.1 & $1-3$ \\
\hline M & 10 & 360 & $315-456$ & 10 & 664 & $431-1165$ & 10 & 2.2 & $1-4$ \\
\hline \multicolumn{10}{|l|}{63} \\
\hline $\mathrm{F}$ & 6 & 365 & $295-431$ & 6 & 700 & $350-1150$ & 6 & 2.8 & $2-5$ \\
\hline NG & 2 & 433 & $391-474$ & 2 & 1250 & $900-1600$ & 2 & 3.5 & $3-4$ \\
\hline \multicolumn{10}{|l|}{512} \\
\hline $\mathrm{F}$ & 7 & 289 & $218-366$ & 7 & 435 & $149-757$ & 7 & 1.3 & $0-3$ \\
\hline M & 8 & 293 & $250-325$ & 8 & 449 & $200-606$ & 8 & 1.3 & $0-3$ \\
\hline NG & 1 & 340 & & 1 & 474 & & 1 & 3.0 & \\
\hline \multicolumn{10}{|l|}{513} \\
\hline $\mathrm{F}$ & 13 & 426 & $312-614$ & 13 & 1417 & $405-4700$ & 12 & 1.8 & $0-5$ \\
\hline M & 9 & 339 & $301-406$ & 9 & 559 & $350-1035$ & 9 & 0.3 & $0-2$ \\
\hline \multicolumn{10}{|l|}{514} \\
\hline $\mathrm{F}$ & 5 & 433 & $348-580$ & 5 & 1454 & $700-3100$ & 5 & 2.4 & $1-3$ \\
\hline $\mathrm{M}$ & 3 & 250 & $229-277$ & 3 & 375 & $175-750$ & 3 & 1 & $0-3$ \\
\hline
\end{tabular}

$\mu \mathrm{g} / \mathrm{g}$, but all northern pike samples were $<\mathrm{LOD}$ (Fig. 2). Geometric mean As concentrations at all stations were relatively low (greatest $=0.22 \mu \mathrm{g} / \mathrm{g}$ at Station 511; Table 11); nevertheless, differences among stations were statistically significant in carp and bass, but not in catfish or Morone sp. (Table 12). Concentrations of As in carp from Station 514, where levels were highest, were significantly greater than those from Station 512, where they were lowest, but few intermediate differences were significant (Table 12). In contrast to carp, As concentrations in bass from Station 514 were lowest and differed significantly from those at Station 512 (Table 12).

Concentrations of As in 1997 differed significantly from historical levels in at least one taxon at Stations 63, 64, and 65 , but there was only one obvious temporal trend-declining concentrations in Morone sp. at Station 65 (Table 13). Historically (1980-86), As concentrations in carp and largemouth bass from Stations 16, 63, and 65 were $\leq 0.27 \mu \mathrm{g} / \mathrm{g}$ and those in Morone sp. from Station 65 were 0.3-0.6 $\mu \mathrm{g} / \mathrm{g}$. Concentrations at Station 64 were $<0.09 \mu \mathrm{g} / \mathrm{g}$ in all past collections, but only brown trout (Salmo trutta) and white sucker (Catostomus commersoni) were collected. Nevertheless, these concentrations did not differ greatly from those in other species collected in 1997 (Fig. 2), and are similar to concentrations reported for salmonids and catostomids from other U.S. rivers (Schmitt, 2004; Schmitt and others, 2002c; Schmitt and others, 1999b). In the 1980s, As concentrations were also high $(>0.3 \mu \mathrm{g} / \mathrm{g})$ in gizzard shad (Dorosoma cepedianum) from Stations 16, 63, and 65, but this species was not collected in 1997. Concentrations in carp from Station 514 and white bass from Station 65 were about the same as those in gizzard shad historically (Fig.
2). They also are about the same as the greatest concentrations detected in carp from areas of high background As in New Mexico by Ong and others (1991) and Roy and others (1992). The range of concentrations encountered in RGB fish was similar to those collected from the MRB in 1995 (Schmitt and others, 2002c) and from the RRN in 1992 (Goldstein and DeWeese, 1999).

Arsenic tends to accumulate in planktivorous clupeids such as gizzard shad (and also sculpins, Cottus sp.) to a greater degree than in other fishes (Hunter and others, 1981; Schmitt and Brumbaugh, 1990; Wagemann and others, 1978) and can be further accumulated by piscivores (Hunter and others, 1981). The occurrence of planktivorous clupeids at some sites and the dynamics of the ecosystems in which they occur may therefore confound trends for As. Schmitt and others (2002c) speculated that the comparatively high concentrations of As in largemouth bass from the southern parts of the MRB, especially in storage impoundments and the river systems containing them, at least partly reflected the presence of gizzard shad and other planktivorous clupeids. The same may be true in the RGB; as noted, previous NCBP collections revealed elevated As concentrations in gizzard shad. Ecosystem and hydrologic differences among stations may also partly explain the comparatively high concentrations in carp and low concentrations in bass from Station 514. Although gizzard shad are present in Amistad International Reservoir, the fish analyzed for this study were collected from the RG below the dam (Table 1).

Areas of elevated As occur naturally in some parts of the RGB, particularly in streams of central New Mexico that drain the Jemez Mountains (Wilcox, 1997). These naturally occur- 


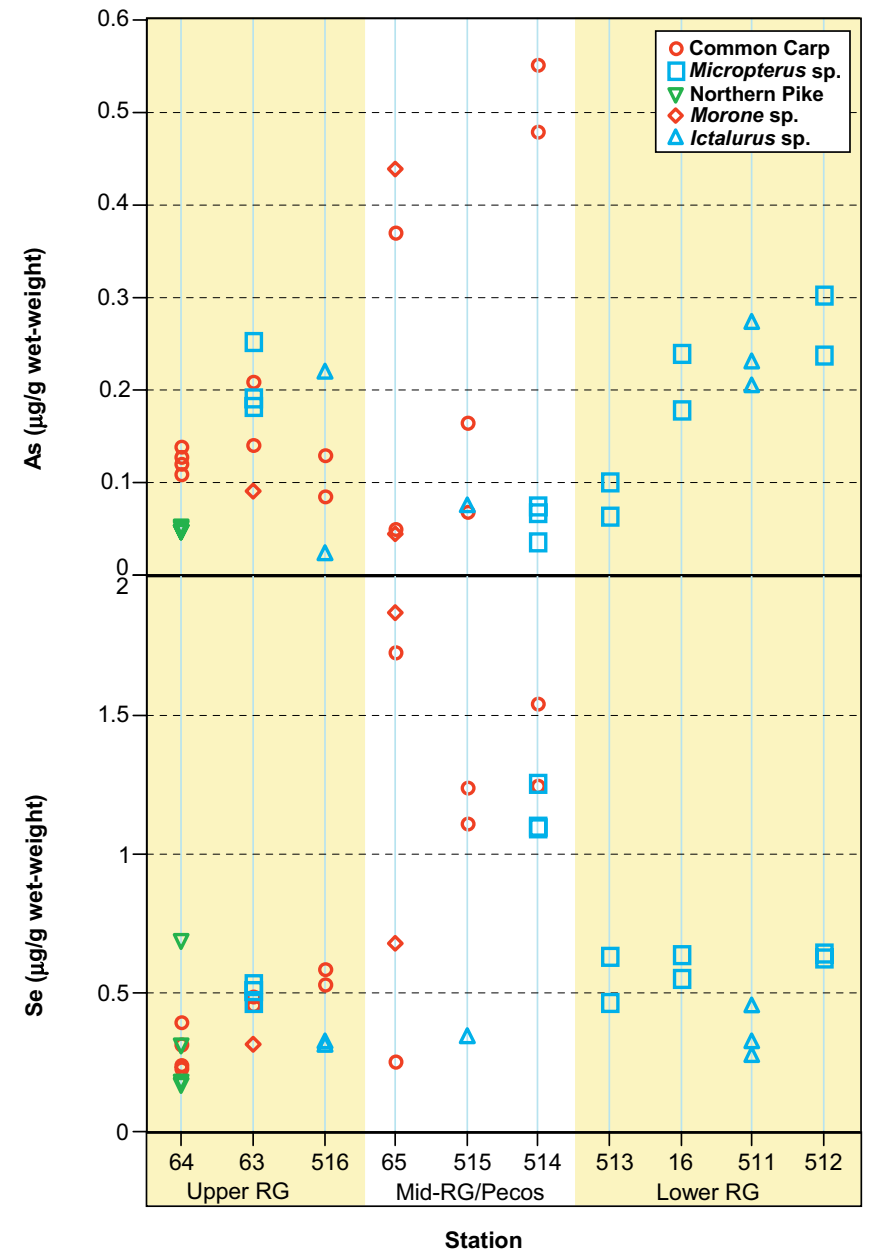

Figure 2. Concentrations of arsenic (As) and selenium (Se) in composite samples of whole fish, by station and taxon. Censored values are plotted as $50 \%$ of LOD. Stations are ordered from upstream to downstream and are grouped by sub-basin. See Table 1 for station descriptions and collection dates. Micropterus sp., largemouth or smallmouth bass; Morone sp., white or striped bass; Ictalurus sp., blue or channel catfish.

ring concentrations were reflected in the 1997 fish samples as well as those of previous investigations. The 1997 concentrations generally paralleled those reported for whole fish collected in 1992-96 from the transboundary portions of the RGB by the Binational Study (TNRCC, 1994a; 1994b; 1997) and by Davis and others (1995). However, the 1992-96 maxima for whole fish $(0.2-0.3 \mu \mathrm{g} / \mathrm{g})$ were lower than what we observed (Fig. 2; Table 10). Roy and others (1992) reported As concentrations as great as $0.62 \mu \mathrm{g} / \mathrm{g}$ in fish from the Alameda Drain, a RG tributary that drains an area of high background As in central New Mexico. In addition to natural sources, As is discharged from sewage treatment plants in some parts of the RGB where As-rich groundwater occurs (Wilcox, 1997), and large amounts of arsenical herbicides are used throughout the RGB for agricultural and domestic weed control. Arsenic-

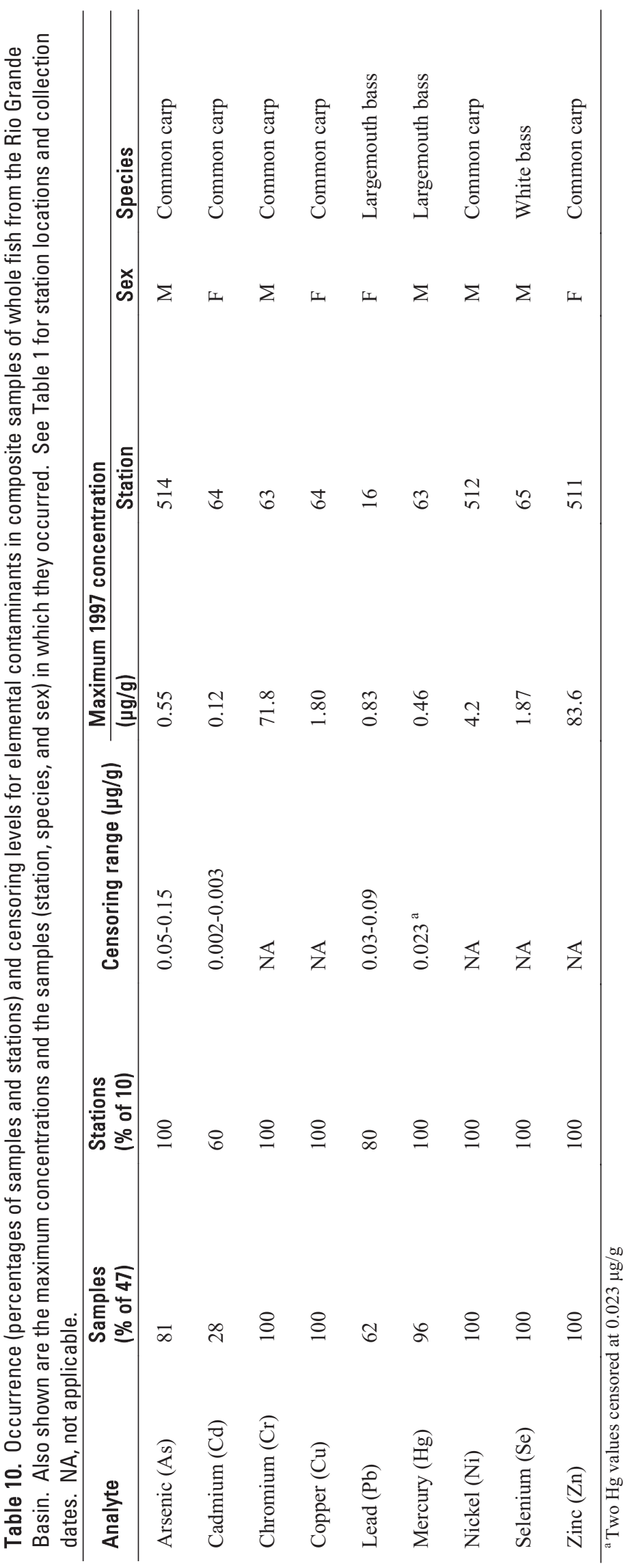


Table 11. Geometric mean, minimum, and maximum concentrations $(\mu \mathrm{g} / \mathrm{g}$, wet-weight) of elemental contaminants in fish from stations in the Rio Grande Basin. Censored values were replaced by 50\% LOD for the computation of station means, but only if at least one value exceeded detection limits. See Table 1 for station locations and collection dates.

\begin{tabular}{|c|c|c|c|c|c|c|c|c|c|c|}
\hline \multirow{2}{*}{ Station } & & \multicolumn{9}{|c|}{ Element } \\
\hline & & As & $\mathrm{Cd}$ & $\mathrm{Cr}$ & $\mathrm{Cu}$ & $\mathrm{Hg}$ & $\mathrm{Ni}$ & $\mathrm{Pb}$ & $\mathrm{Se}$ & $\mathrm{Zn}$ \\
\hline 16 & Mean & 0.20 & 0.03 & 1.08 & 0.62 & 0.20 & 0.24 & 0.21 & 0.66 & 29.8 \\
\hline \multirow[t]{2}{*}{$(n=4)$} & Min. & 0.15 & $<0.03$ & 0.71 & 0.36 & 0.20 & 0.18 & 0.08 & 0.56 & 11.5 \\
\hline & Max. & 0.24 & 0.07 & 1.59 & 1.23 & 0.20 & 0.31 & 0.83 & 0.74 & 75.3 \\
\hline \multirow{3}{*}{$\begin{array}{l}63 \\
(n=6)\end{array}$} & Mean & 0.17 & 0.02 & 9.51 & 0.67 & 0.24 & 1.06 & 0.04 & 0.45 & 22.8 \\
\hline & Min. & 0.09 & $<0.02$ & 5.46 & 0.42 & 0.15 & 0.57 & $<0.06$ & 0.32 & 11.5 \\
\hline & Max. & 0.25 & 0.08 & 71.76 & 1.16 & 0.46 & 2.14 & 0.10 & 0.54 & 75.2 \\
\hline \multirow{3}{*}{$\begin{array}{l}64 \\
(n=8)\end{array}$} & Mean & 0.08 & 0.03 & 1.12 & 1.06 & 0.09 & 0.48 & 0.08 & 0.29 & 51.1 \\
\hline & Min. & $<0.09$ & $<0.02$ & 0.28 & 0.74 & $<0.02$ & 0.19 & $<0.07$ & 0.17 & 28.4 \\
\hline & Max. & 0.14 & 0.12 & 9.86 & 1.80 & 0.18 & 1.88 & 0.26 & 0.69 & 81.0 \\
\hline \multirow{3}{*}{$\begin{array}{l}65 \\
(n=4)\end{array}$} & Mean & 0.14 & $<0.03$ & 0.51 & 0.74 & 0.04 & 0.43 & $<0.07$ & 0.86 & 31.9 \\
\hline & Min. & $<0.09$ & $<0.02$ & 0.38 & 0.56 & $<0.02$ & 0.25 & $<0.07$ & 0.25 & 19.1 \\
\hline & Max. & 0.44 & $<0.03$ & 0.68 & 0.95 & 0.18 & 0.77 & $<0.07$ & 1.87 & 52.0 \\
\hline \multirow{3}{*}{$\begin{array}{l}511 \\
(n=5)\end{array}$} & Mean & 0.22 & $<0.03$ & 11.43 & 0.49 & 0.09 & 0.34 & 0.21 & 0.43 & 30.4 \\
\hline & Min. & 0.18 & $<0.03$ & 5.82 & 0.29 & 0.07 & 0.18 & 0.11 & 0.28 & 12.6 \\
\hline & Max. & 0.27 & $<0.03$ & 33.98 & 0.91 & 0.13 & 0.70 & 0.42 & 0.60 & 83.6 \\
\hline \multirow{3}{*}{$\begin{array}{l}512 \\
(n=4)\end{array}$} & Mean & 0.13 & $<0.03$ & 13.57 & 0.60 & 0.09 & 0.99 & 0.08 & 0.62 & 31.1 \\
\hline & Min. & 0.05 & $<0.02$ & 10.00 & 0.43 & 0.07 & 0.37 & $<0.05$ & 0.59 & 14.6 \\
\hline & Max. & 0.30 & $<0.03$ & 18.31 & 0.82 & 0.12 & 4.21 & 0.21 & 0.65 & 61.5 \\
\hline \multirow{3}{*}{$\begin{array}{l}513 \\
(n=4)\end{array}$} & Mean & 0.14 & $<0.03$ & 28.51 & 0.88 & 0.09 & 0.95 & 0.11 & 0.61 & 25.4 \\
\hline & Min. & 0.06 & $<0.03$ & 10.73 & 0.59 & 0.07 & 0.34 & 0.07 & 0.47 & 13.3 \\
\hline & Max. & 0.26 & $<0.03$ & 70.15 & 1.63 & 0.14 & 3.29 & 0.18 & 0.68 & 57.2 \\
\hline \multirow{3}{*}{$\begin{array}{l}514 \\
(n=5)\end{array}$} & Mean & 0.13 & 0.02 & 4.02 & 0.90 & 0.16 & 0.28 & 0.05 & 1.22 & 19.5 \\
\hline & Min. & 0.04 & $<0.02$ & 2.81 & 0.66 & 0.07 & 0.23 & $<0.03$ & 1.10 & 11.1 \\
\hline & Max. & 0.55 & 0.06 & 10.36 & 1.56 & 0.40 & 0.47 & 0.20 & 1.54 & 59.0 \\
\hline \multirow{3}{*}{$\begin{array}{l}515 \\
(n=3)\end{array}$} & Mean & 0.10 & 0.04 & 16.57 & 1.12 & 0.15 & 0.50 & $<0.09$ & 0.78 & 43.2 \\
\hline & Min. & $<0.14$ & $<0.03$ & 14.40 & 0.91 & 0.14 & 0.49 & $<0.03$ & 0.35 & 16.6 \\
\hline & Max. & 0.17 & 0.07 & 21.80 & 1.27 & 0.16 & 0.50 & $<0.09$ & 1.24 & 73.4 \\
\hline \multirow{3}{*}{$\begin{array}{l}516 \\
(n=4)\end{array}$} & Mean & 0.09 & 0.02 & 10.34 & 0.90 & 0.06 & 0.39 & 0.07 & 0.43 & 34.8 \\
\hline & Min. & $<0.05$ & $<0.02$ & 6.90 & 0.54 & 0.05 & 0.36 & $<0.05$ & 0.32 & 17.9 \\
\hline & Max. & 0.22 & 0.07 & 16.19 & 1.29 & 0.06 & 0.42 & 0.13 & 0.59 & 73.7 \\
\hline
\end{tabular}

containing compounds are also used to defoliate cotton, which is grown in many parts of the RGB, and As and other elemental contaminants are released during the smelting of metals and the combustion of coal. Consequently, As was among the eight elements associated with the combustion of fossil fuels for which Van Metre and others (1997) reported increasing concentrations in sediment cores from Amistad Reservoir. In contrast, As concentrations in cores from Llano Grande Lake did not change appreciably from 1989 to 2001 (Mahler and Van Metre, 2002). Arsenic was also among the elemental contaminants detected at elevated concentrations in fish (liver samples) and other matrices obtained from the RG below the Creede, Colorado mining district in 1992-93 (Carter and Anderholm, 1997; Levings and others, 1998); however, 1997 


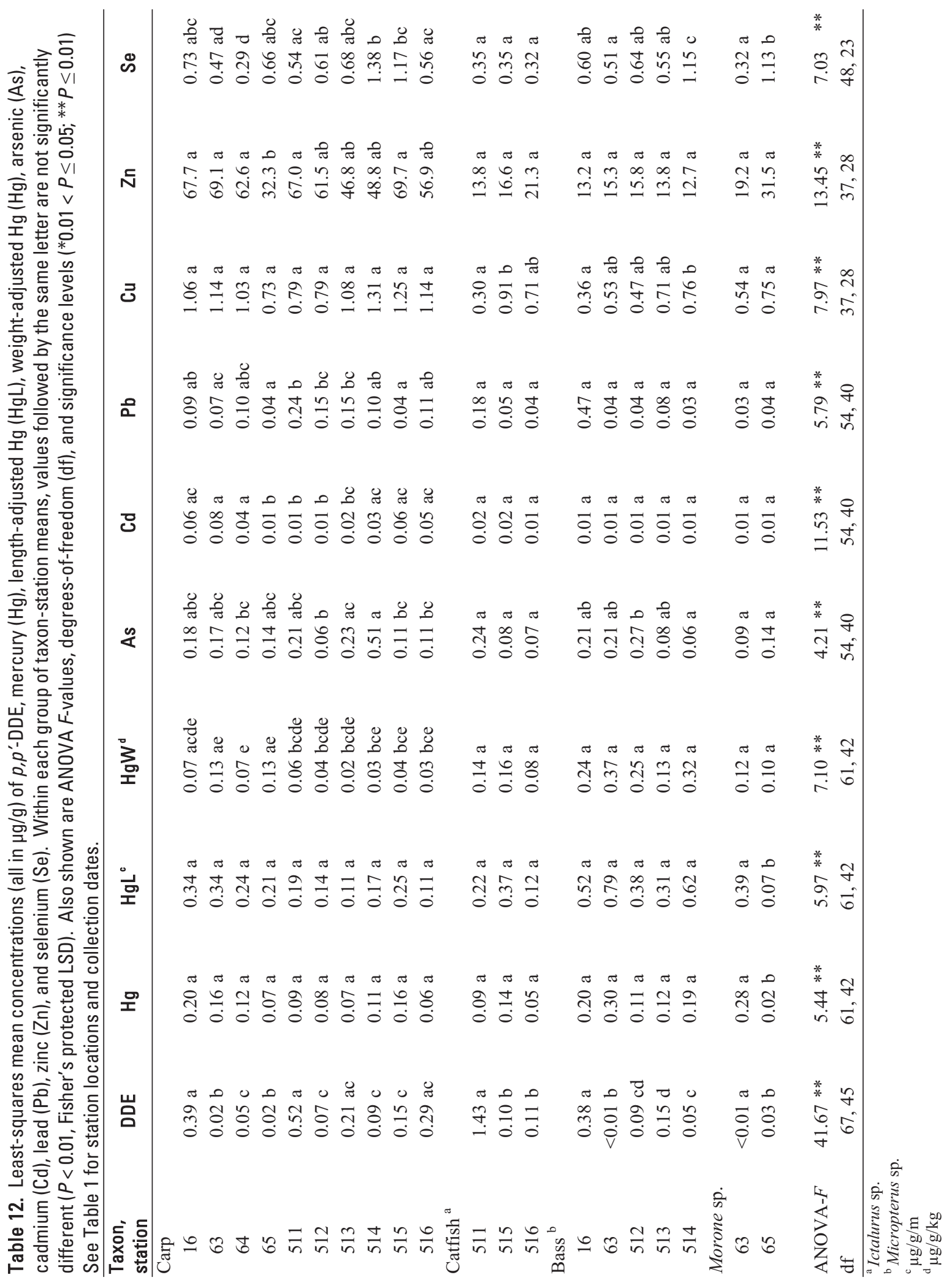


concentrations in fish from Station 64 (RG at Alamosa, CO), which is downstream of these sources, were low (Fig. 2). In contrast, concentrations of As were 2- to 10-fold greater (1-3 $\mu \mathrm{g} / \mathrm{g}$ ) in several species of fish collected in 1996 from resacas along the lower RG (Mora and others, 2001) than the greatest concentrations in 1997 samples from the RGB (Fig. 2). Mora and others (2001) attributed the elevated concentrations in the resacas to municipal wastes; however, given the intensity of the agricultural activity in the lower RG valley and the fact that cotton and vegetables are among the crops produced (Mora and others, 2001), arsenical pesticides, defoliants, or both may also have contributed to the elevated concentrations. Mora and Wainwright (1997), citing data from the Texas Agricultural Extension Service, noted that almost 85,000 kg of "harvest aids", a category which includes defoliants, were used in the region comprising the lower RG valley in 1994. The U.S. Department of Agriculture also reported that 98,000 lbs $(>44,000 \mathrm{~kg})$ of arsenical herbicides and 1.8 million lbs (0.8 million $\mathrm{kg}$ ) of arsenical defoliants were used on cotton in Texas and Oklahoma during 1976 (Eichers and others, 1978).

Elevated concentrations of As in fish as a result of natural sources have prompted human consumption advisories in parts of New Mexico (Wilcox, 1997). However, the As concentrations in the RGB fish collected in $1997(0.14-0.55 \mu \mathrm{g} / \mathrm{g})$ were not sufficiently high to represent a hazard to the fish or to piscivorous wildlife according to current criteria (USEPA, 1999). A review by Jarvinen and Ankley (1999) included several laboratory studies in which As effects were evaluated relative to whole-body concentrations. For example, concentrations of 8.1-13.5 $\mu \mathrm{g} / \mathrm{g}$ were associated with loss of equilibrium and $5.4 \mu \mathrm{g} / \mathrm{g}$ caused increased mortality in rainbow trout (Oncorhynchus mykiss) fingerlings (McGreachy and Dixon, 1990; McGreachy and Dixon, 1992). Adult bluegill experienced reduced survival and growth at $11.6 \mu \mathrm{g} / \mathrm{g}$ (Gilderhus, 1966). Arsenic concentrations in all fish from the RGB were below these effect levels. In addition, As is largely accumulated by freshwater fish as organo-arsenical compounds, which are less toxic than inorganic forms (Law, 1996; Maeda, 1994).

\section{Selenium}

Selenium was detected in all samples from all stations at concentrations of $0.17-1.87 \mu \mathrm{g} / \mathrm{g}$, with the maximum occurring in male white bass from Station 65 (PR at Red Bluff Lake; Table 10; Fig. 2). Concentrations $\geq 0.5 \mu \mathrm{g} / \mathrm{g}$ were present in at least one sample from all stations, and all samples from Station 514 (RG at Amistad Reservoir) as well as two from each of Stations 515 (RG at Langtry) and 65 contained $>1.0 \mu \mathrm{g} / \mathrm{g}$ (Fig. 2). At Station 65, both of the greatest concentrations $(>1.5 \mu \mathrm{g} / \mathrm{g})$ were in samples representing male fish (carp and white bass); concentrations in corresponding samples of female fish were lower (Fig. 2). At Station 514, Se concentrations in largemouth and smallmouth bass did not differ appreciably (Fig. 2) even though one of the largemouth bass samples comprised relatively small fish; however, these differences were not tested statistically (data not shown). Concentrations in male and female carp from this site were also similar to each other (Fig. 2). At Station 63, the only other site from which both largemouth and smallmouth bass were collected, concentrations in bass were uniformly low (about $0.5 \mu \mathrm{g} / \mathrm{g}$ ). The greatest Se geometric station mean was for Station $514(1.25 \mu \mathrm{g} / \mathrm{g}$; Table 11). Other stations with means $>0.5 \mu \mathrm{g} / \mathrm{g}$ included Stations 16, 65, 512, 513, and 515 (Table 11). Concentrations of Se were greatest in bass from Station 514, carp from Stations 65, 515, and 514, and white bass from Station 65 (male only; Fig. 2). Differences among or between stations were statistically significant in all taxa except catfish (Table 12).

The greatest Se concentrations in fish from the RGB (1-2 $\mu \mathrm{g} / \mathrm{g}$ ) exceeded those from all stations sampled in the MRB during 1995 except one (Schmitt and others, 2002c). Concentrations in RGB carp also exceeded those in carp collected from the RRN in 1994 by Goldstein and DeWeese (1999), which averaged $1.18 \mu \mathrm{g} / \mathrm{g} \mathrm{dw}$ (about $0.35 \mu \mathrm{g} / \mathrm{g} \mathrm{ww}$ ). However, although high compared to other parts of the RGB, the maximum RGB concentrations (1-2 $\mu \mathrm{g} / \mathrm{g}$ ) are typical for fish from seleniferous areas supporting irrigated agriculture. In addition, they are lower by at least $50 \%$ than the $3-5 \mu \mathrm{g} / \mathrm{g}$ reported for carp and bass collected in 1995 from one MRB site heavily affected by irrigated agriculture (Schmitt, 2004; Schmitt and others, 2002c; 1999b).

Concentrations of Se in 1997 were generally within the range of 1980-86 NCBP values at Stations 16, 64, and 65 (Schmitt and others, 1999b) when comparisons are restricted to the same species. In fact, the only statistically significant and obvious temporal trend for Se (in Morone sp. from Station 65) has been downward (Table 13). Relative to historical values for Station 64 (RG at Alamosa), the 1997 concentration $(0.69 \mu \mathrm{g} / \mathrm{g})$ in northern pike was high; however, northern pike had not been collected previously at this site, and the concentration is within the range of reported values for this species in other U.S. rivers (Schmitt and others, 2002c; Schmitt and others, 1999b). Selenium concentrations $>1.0 \mu \mathrm{g} / \mathrm{g}$ and in white bass from Station 65 confirmed previous findings; levels of 1.5 to $>3.0 \mu \mathrm{g} / \mathrm{g}$ were reported in white bass from Station 65 in 1978-84 (Lowe and others, 1985; Schmitt and others, 1999b). Concentrations in carp from Station $63($ mean $=0.47 \mu \mathrm{g} / \mathrm{g}$ ) have not changed appreciably over the last decade (Table 13) and are about the same as levels in carp from the RG in New Mexico and Bosque del Apache NWR during the 1980s (Ong and others, 1991). The USFWS reported elevated Se concentrations in carp from 10-Mile Reservoir and Bitter Lake NWR, which are on the Pecos River in New Mexico (unpublished data, USFWS, Albuquerque, NM). The USFWS also detected elevated concentrations in the eggs of fish-eating birds at Bitter Lake NWR.

In the RG mainstem, the Binational Study (TNRCC, 1994b; 1997) reported Se concentrations $>1.0 \mu \mathrm{g} / \mathrm{g}$ in whole carp and channel catfish collected from 1992 through 1996 below El Paso (near Station 516), in white bass and carp at Langtry (near Station 515), and in carp and bass below Amis- 


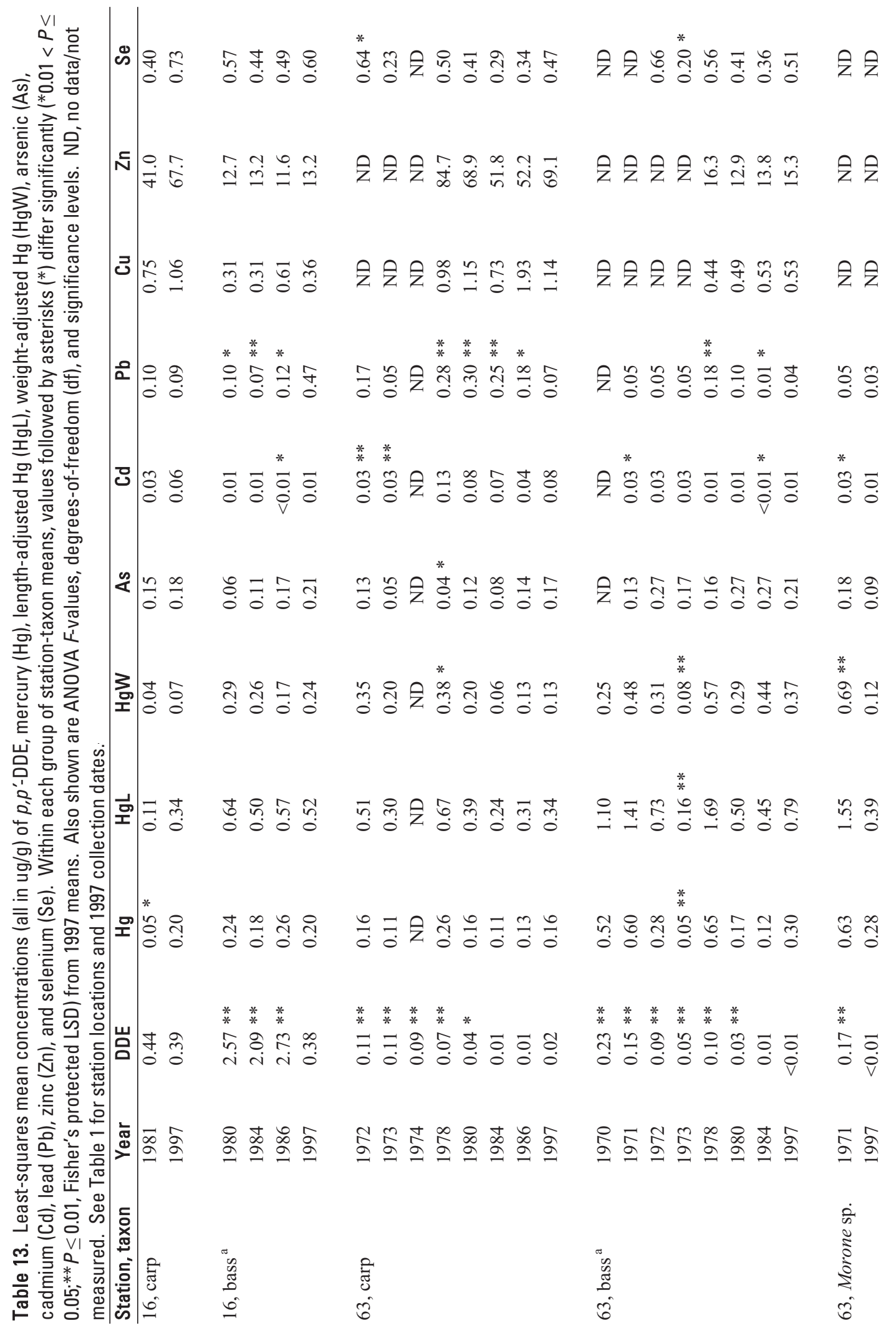




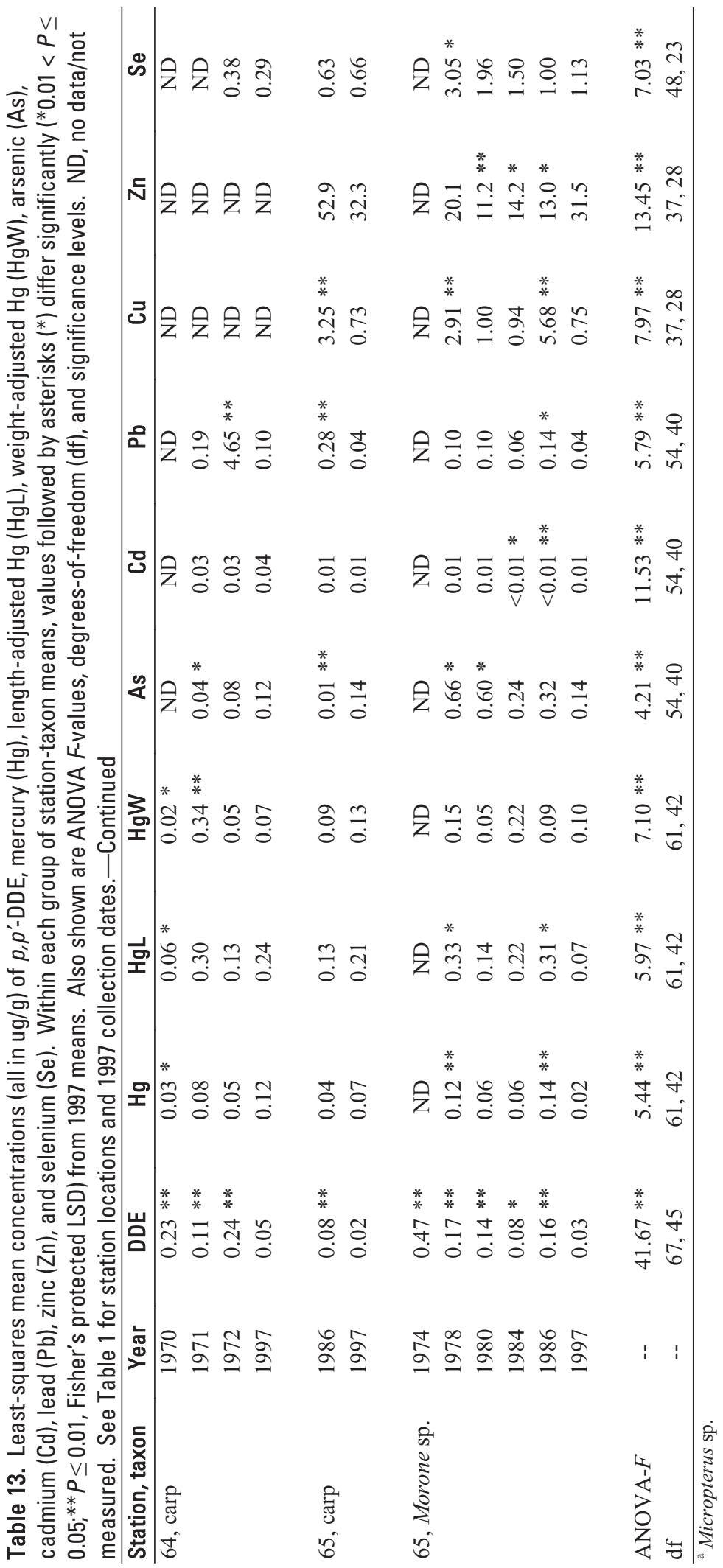


tad International Reservoir (Davis and others, 1995). However, and although it is an important component of fossil fuel emissions, Se was not among the eight elements analyzed in sediment cores from Amistad Reservoir by Van Metre and others (1997). Mora and others (2002) reported elevated concentrations in several avian prey species of the peregrine falcon sampled in 1996 from the Big Bend area, and concluded that Se probably originating from agricultural activities was among the contaminants potentially responsible for impaired reproduction in this Federally listed species. Further downstream, concentrations of Se in fish collected in 1996 from resacas along the lower RG were $<0.8 \mu \mathrm{g} / \mathrm{g}$ (Mora and others, 2001), as were those in contemporaneously collected fish from the lower reaches of the river itself (Davis and others, 1995; TNRCC, 1994b; 1997). In the upper RG, Se was detected at elevated concentrations in sediment, but one sample of carp liver collected in 1992-93 was among the greatest measured by the NAWQA program (Carter and Anderholm, 1997; Levings and others, 1998).

Several studies that evaluated effects relative to wholebody Se concentrations in fish were included in the review by Jarvinen and Ankley (1999). Among these were several showing that concentrations of $8-16 \mu \mathrm{g} / \mathrm{g}$ (dw; estimated 1.6-3.2 ww assuming $80 \%$ moisture) were associated with reproductive failure in fathead minnows (Pimephales promelas) (Schultz and Hermanutz, 1990) and bluegill (Baumann and Gillespie, 1986; Coyle and others, 1993; Hermanutz and others, 1992). Coyle and others (1993) suggested that maternally transferred Se could affect hatching success and larval survival, and noted that it is essential to examine multiple life stages to correctly assess toxicity/tissue concentration relationships (Jarvinen and Ankley 1999). According to the criteria of Lemly (1996; 2002), whole-body Se concentrations should not exceed $4 \mu \mathrm{g} / \mathrm{g}$ dry weight (about $0.8 \mu \mathrm{g} / \mathrm{g}$ wet-weight assuming $80 \%$ moisture) to avoid toxicity to the fish and $3 \mu \mathrm{g} / \mathrm{g}$ dry weight (about $0.6 \mu \mathrm{g} / \mathrm{g}$ wet-weight) to protect piscivorous wildlife. Individual samples and three station means (Stations 65, 514, and 515) exceeded Lemly's fish threshold, and three additional station means, along with numerous samples, approached or exceeded the wildlife value (Fig. 2; Table 11). In addition, Se was among the contaminants identified as potential threats to Laguna Atascosa and other NWRs in the RGB (USFWS, 1986), a concern that appears to remain warranted.

\section{Mercury}

Mercury (as total $\mathrm{Hg}$ ) was detected $(>0.023 \mu \mathrm{g} / \mathrm{g} \mathrm{ww}$ ) in 45 of 47 samples (96\%) from all 10 stations (Table 10). Concentrations were generally greatest in predatory fishes; the exception was $\mathrm{Hg}$ in northern pike from Station 64, which varied more than most (Fig. 3). Concentrations were $>0.25 \mu \mathrm{g} / \mathrm{g}$ in largemouth bass and striped bass from Stations 63; however, levels in smallmouth bass and carp from this site were lower $(<0.20 \mu \mathrm{g} / \mathrm{g}$; Fig. 3), which is typical for these species (Bahn-

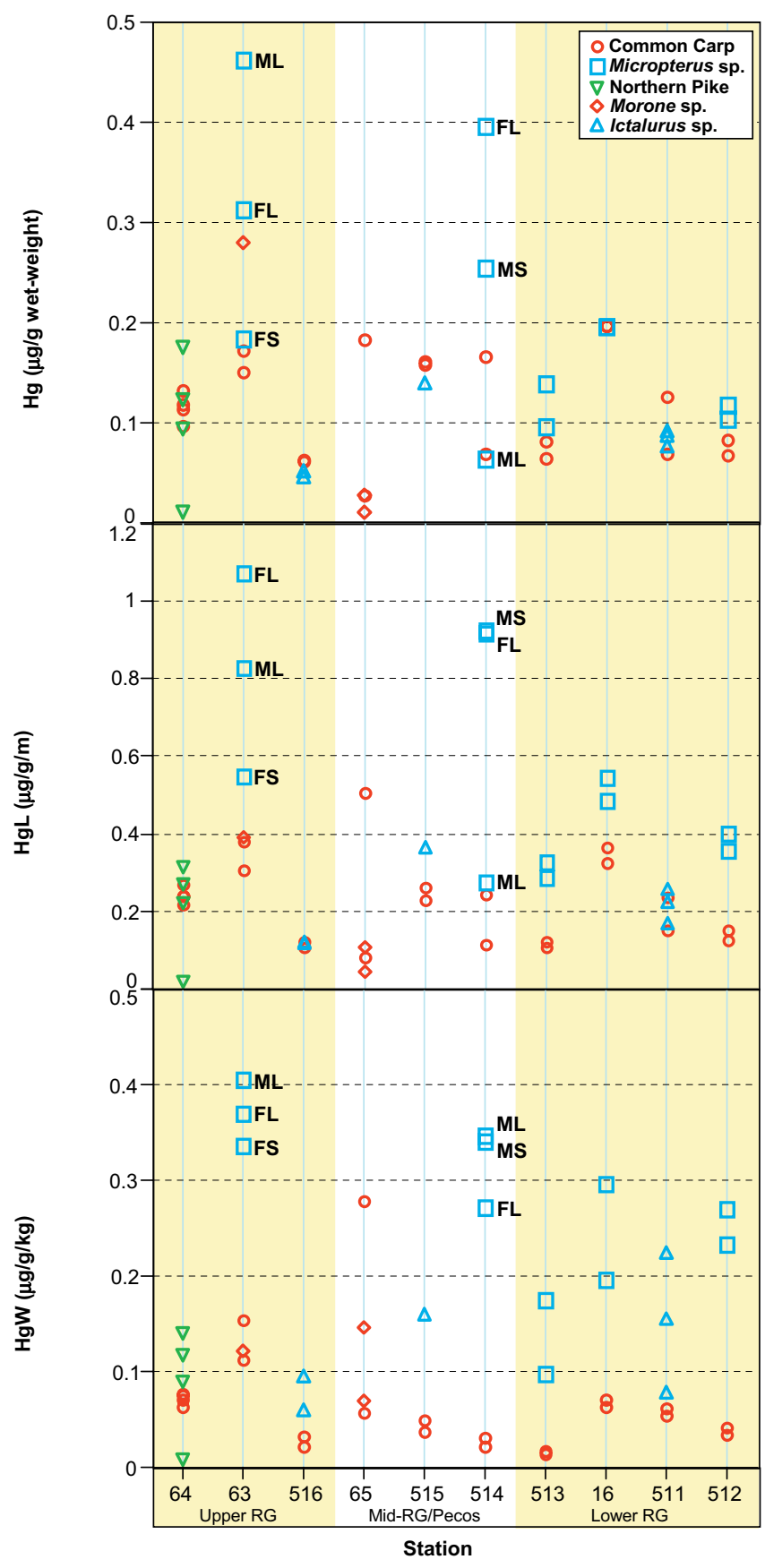

Figure 3. Concentrations of mercury in composite samples of whole fish, by station and taxon. Shown are unadjusted concentrations $(\mathrm{Hg})$, length-adjusted concentrations $(\mathrm{HgL})$, and weightadjusted concentrations ( $\mathrm{HgW}$ ). Also shown for Stations 63 and 514 are individual samples comprising male (M) and female (F) largemouth (L) and smallmouth (S) bass referred to in the text. Censored values are plotted as 50\% of LOD. Stations are ordered from upstream to downstream and are grouped by sub-basin. See text for computations and Table 1 for station descriptions and collection dates. Micropterus sp., largemouth or smallmouth bass; Morone sp., white or striped bass; Ictalurus sp., blue or channel catfish. 
ick and others, 1994; Brumbaugh and others, 2001; Goldstein and others, 1996; Goldstein and DeWeese, 1999; Schmitt and others, 2002c; 1999b). The maximum 1997 geometric station mean $(0.24 \mu \mathrm{g} / \mathrm{g})$ also occurred at Station 63 (Table 11). The next greatest was $0.20 \mu \mathrm{g} / \mathrm{g}$ (Station 16), with all others $\leq 0.15$ $\mu \mathrm{g} / \mathrm{g}$ (Table 11). Elephant Butte Reservoir (Station 63) has a well-documented history of $\mathrm{Hg}$ contamination, and fish consumption advisories have been issued for sport fish (Appendix Table 1).

The maximum 1997 concentration of total $\mathrm{Hg}$ in an individual sample was $0.46 \mu \mathrm{g} / \mathrm{g}$, in male largemouth bass from Station 63 (Table 10). Concentrations in female largemouth bass and smallmouth bass from Station 63 were lower (Fig. 3). However, the male largemouth bass from Station 63 were larger on average (433 $\mathrm{mm}, 1250 \mathrm{~g}$ ) than the females (379 $\mathrm{mm}, 775 \mathrm{~g})$ and the smallmouth bass $(338 \mathrm{~mm}, 550 \mathrm{~g}$; Table 9). Consequently, some of the relative differences among the three samples were removed by adjusting for fish length (Fig. 3). Adjusting for weight reversed the relative concentrations in male and female largemouth bass, but all values for smallmouth bass were lower than those in largemouth bass (Fig. 3). These results indicate that the among-species concentration differences at Station 63 were not strictly related to differing fish sizes among the samples. Largemouth and smallmouth bass were also obtained from Station 514. At this site, concentrations were greatest in female largemouth bass $(0.40 \mu \mathrm{g} / \mathrm{g})$ and lowest in male largemouth bass $(0.07$ $\mu \mathrm{g} / \mathrm{g})$; concentrations in smallmouth bass were intermediate (Fig. 3). The mean length and weight of the male largemouth bass from Station 514 were considerably lower (that is, the fish were smaller) than the other two samples (Table 9). As was true for Station 63, most among-sample differences were removed by adjusting for fish length, but not weight (Fig. 3 ), primarily because the male largemouth bass sample, with the lowest total $\mathrm{Hg}$ concentration, also comprised small fish (237 mm, $188 \mathrm{~g}$ ) relative to the other two samples (277-432 mm, 750-1454 g). Stations 515 (RG at Langtry) and 514 (below Amistad Dam) are downstream from the Terlingua (Texas) mining district, where $\mathrm{Hg}$ was extracted from cinnabar deposits for nearly a century (Sharpe, 1980). Mora and others (2002) reported elevated concentrations of $\mathrm{Hg}$ in several avian prey species of the peregrine falcon sampled in 1996 from the Big Bend area, and concluded that $\mathrm{Hg}$ probably originating from the Terlingua district was among the contaminants potentially responsible for impaired reproduction in this species. Although total $\mathrm{Hg}$ concentrations in bass from Station 514 were high relative to most other sites in the RGB, those in carp and catfish from Station 515 were not (Fig. 3).

Despite apparent among-station differences for total $\mathrm{Hg}$ in bass, only differences in Morone sp. and carp were statistically significant (Table 12$)$. Un-adjusted $(\mathrm{Hg})$ and lengthadjusted $(\mathrm{HgL})$ total $\mathrm{Hg}$ concentrations in Morone sp. were significantly greater at Station 63 than at Station 65 (Fig. 3; Table 12). The weight-adjusted concentrations $(\mathrm{HgW})$ did not differ significantly among stations for any predator species; however, weight-adjusted differences in carp were statistically significant (Table 12). Statistical analysis of the bass alone yielded similar results (Table 14). In addition, the relative rankings of the stations within each taxon grouping in both analyses was similar for $\mathrm{Hg}, \mathrm{HgL}$, and $\mathrm{HgW}$ (Tables 12 and 14); however, the magnitude of the among-sample differences at each station were smaller for the adjusted values (Fig. 3; Tables 12 and 14), indicating that some of the observed differences were related to fish size. Nevertheless, most relative differences remained after adjustment, which suggests that spatial differences were not entirely artifacts of fish size.

Concentrations of total $\mathrm{Hg}$ in bass changed significantly at several stations in collections spanning the period 1970-97, and these differences were consistent for $\mathrm{Hg}, \mathrm{HgL}$, and $\mathrm{HgW}$ (Table 13). In addition, the same results were obtained when the analysis was restricted to bass (Table 14). Overall, $\mathrm{Hg}$ concentrations in bass at Station 63, Morone sp. at Stations 63 and 65, and carp at Station 64 differed significantly among years (Tables 13 and 14), but there were no clearly evident temporal trends at any of these stations. As noted for the geographic differences, the ordering of the years within taxa was identical for $\mathrm{Hg}, \mathrm{HgL}$, and $\mathrm{HgW}$ even though the mean size of bass from Stations 16 and 63 varied substantially from 1970-97 (Table 14). The size differences were not statistically significant, however (Table 14). In addition, the size range of the bass from these stations was smaller than that spanned by the NAWQA program's national Hg pilot study (Brumbaugh and others, 2001) in which $\mathrm{HgL}$ and $\mathrm{HgW}$ computed in this manner were also used to normalize concentrations relative to fish size. Overall, the results of these analyses indicate that the among-year concentration differences were also not overly influenced by differences in the sizes of the fish comprised by the samples.

In 1997, total $\mathrm{Hg}$ concentrations in largemouth bass from Station 16, smallmouth bass and carp from Station 63, and white bass from Station 65 were within the range of 1980-86 concentrations in those species (Schmitt and others, 1999b). Concentrations of total $\mathrm{Hg}$ at Station 64 were relatively low in the 1980s and in 1997, but no species from Station 64 were common to collections during this period. However, a composite sample of brown trout collected in 1987 from the RG near the Colorado-New Mexico state line contained $0.20 \mu \mathrm{g} / \mathrm{g}$ (Roy and others, 1992). At Station 63, total Hg concentrations in both male and female largemouth bass returned to levels reported during the 1970s (Lowe and others, 1985; May and McKinney, 1981) following a decade-long decline (Table 13) (Schmitt and Brumbaugh, 1990; Schmitt and others, 1999b). Total Hg concentrations in carp were also greater in 1997 than during the 1980s, but the differences were not as great as in bass (Table 13). Concentrations of $\mathrm{Hg}$ in fish collected during the 1980s by Ong and others (1991) from the RG in New Mexico were universally low; levels in whole carp from the RG upstream of Elephant Butte Reservoir were all $<0.025 \mu \mathrm{g} /$ $\mathrm{g}$, and carp from the reservoir contained only $0.10 \mu \mathrm{g} / \mathrm{g}$. The cycling of $\mathrm{Hg}$ in Elephant Butte Reservoir is related to water level fluctuations and the associated growth and decomposition of riparian vegetation as well as to the possible presence 


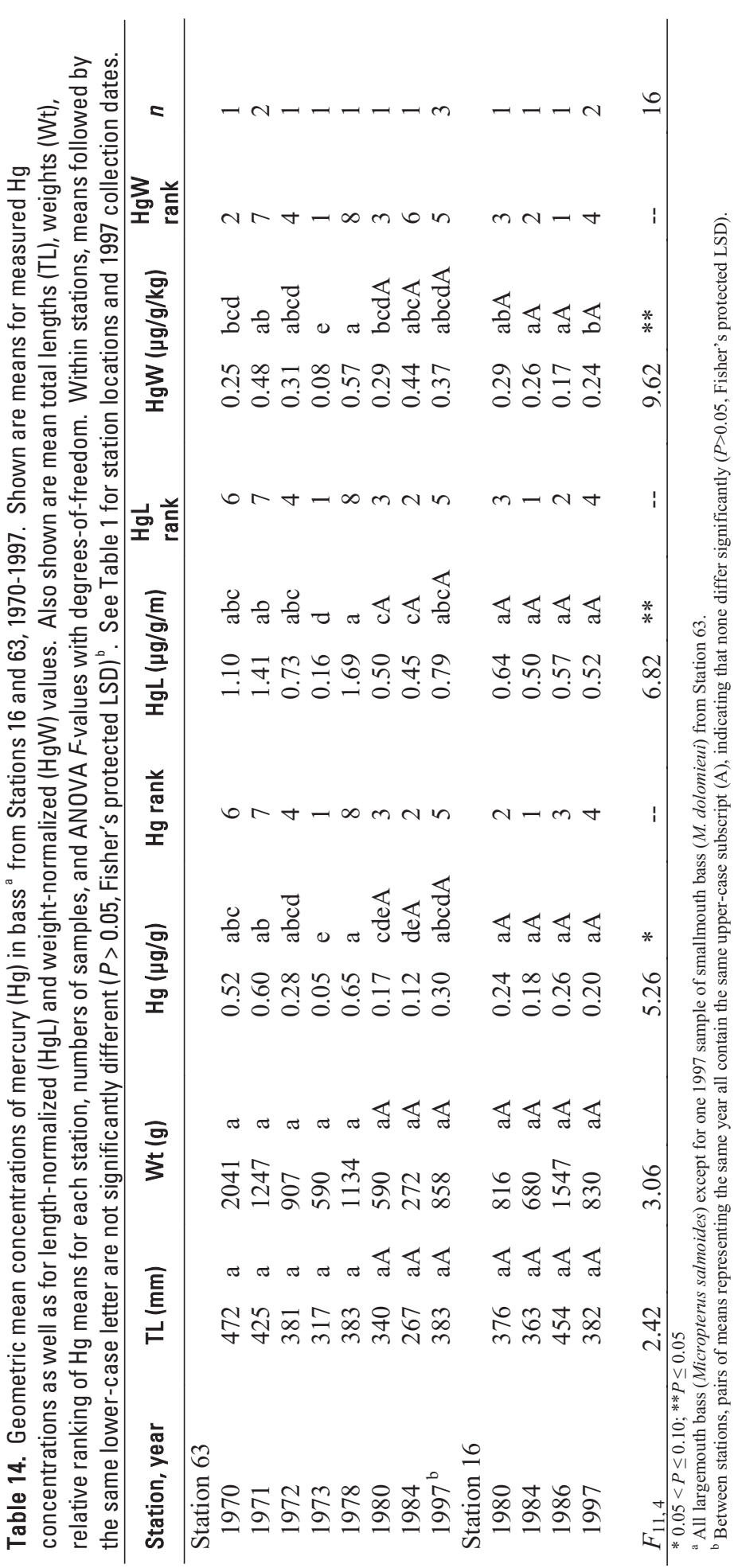

of sulfide-rich springs and atmospheric sources (Garcia and Kidd, 1979). Strong and prolonged thermal stratification and an associated anoxic hypolimnion characterize the lake in summer, which enhances $\mathrm{Hg}$ methlyation (Canavan and others, 2000). In addition, ecosystem structure and dynamics profoundly influence $\mathrm{Hg}$ accumulation; food chain length is particularly important (Cabana and others, 1994). The extent to which theses factors changed over time and their attendant effects on $\mathrm{Hg}$ in predatory fish is not known.

In the transboundary portions of the RGB, 1997 total $\mathrm{Hg}$ concentrations were generally similar to those reported for whole fish collected during 1992-96 by the Binational Study (TNRCC, 1994b; 1997) and by Davis and others (1995). They were also similar to concentrations in fish from resacas along the lower RG (Mora and others, 2001). Mercury was the only elemental contaminant measured in USEPA's National Study of Chemical Residues in Fish (Bahnick and others, 1994; USEPA, 1992a; 1992b); concentrations were $0.49 \mu \mathrm{g} / \mathrm{g}$ in white bass fillets and $0.11 \mu \mathrm{g} / \mathrm{g}$ in whole carp obtained in 1987 from the Rio Grande at El Paso, both of which were greater than 1997 whole-fish concentrations at Station 516 (Fig. 3). Similarly, concentrations of $0.38-0.93 \mu \mathrm{g} / \mathrm{g}$ were documented in fillet samples of white bass, largemouth bass, and carp obtained in 1993 from the Mercedes diversion canal, along the AC upstream of Harlingen, Texas [unpublished TDH data summarized by Mora, 2001]. Further downstream, USEPA reported $0.10 \mu \mathrm{g} / \mathrm{g}$ in whole channel catfish from the AC at Harlingen, which is nearly identical to 1997 concentrations in this species from Station 511 (Fig. 3). In the upper RG, concentrations in 1997 samples of striped bass and smallmouth bass from Station 63 were similar to those reported for white bass $(0.21 \mu \mathrm{g} / \mathrm{g})$ obtained from Elephant Butte and Caballo reservoirs in 1996 by Caldwell and others (1999), but 1997 concentrations in largemouth bass and striped bass were greater (Fig. 3). Forage species (Dorosoma sp.) from both reservoirs contained 0.05-0.13 $\mu \mathrm{g} / \mathrm{g}$ in 1996 (Caldwell and others, 1999).

In the upper RGB, highly elevated concentrations of $\mathrm{Hg}$ were reported in sediment, but not fish (liver samples), collected at sites below the Creede, Colorado mining district in 1992-93 by the NAWQA program (Carter and Anderholm, 1997; Levings and others, 1998). Concentrations of total $\mathrm{Hg}$ in northern pike collected in 1997 from Station 64, which is downstream of the mining district, were $0.09-0.18 \mu \mathrm{g} / \mathrm{g}$ (Fig. 3). These concentrations are within the 1970-86 range $(<0.01-0.21 \mu \mathrm{g} / \mathrm{g})$ reported in NCBP brown trout from this site (Schmitt and others, 1999b). Similarly, brown trout fillets obtained in 1987 from the Rio Mora, a headwater stream in northeastern New Mexico sampled as a reference site by USEPA (1992b), contained $0.07 \mu \mathrm{g} / \mathrm{g}$. Concentrations in whole carp and channel catfish collected from the RGB in 1997 were also generally similar to those reported for the RRN by Goldstein and others (1996).

The 1997 concentrations of total $\mathrm{Hg}$ in fish from Station 63 (ca. 0.2-0.5 $\mu \mathrm{g} / \mathrm{g}$ ) remained high relative to other RGB stations, and fish consumption advisories were consequently 
in effect (Appendix Table 1). Similar concentrations were present in predatory fish collected from many of the MRB stations sampled in 1995 (Schmitt and others, 2002c), from many northeastern U.S. lakes (Yeardley and others, 1998), and from Oregon streams (Peterson and others, 2002). Nationally, concentrations of total $\mathrm{Hg}$ in fish obtained by USEPA in 1987 from waters affected by point-sources were as great as 1.2-1.8 $\mu \mathrm{g} / \mathrm{g}$ (Bahnick and others, 1994; USEPA, 1992a). Concentrations were also as great as $1.8 \mu \mathrm{g} / \mathrm{g}$ in largemouth bass fillets and $5.8 \mu \mathrm{g} / \mathrm{g}$ in white bass fillets obtained from NAWQA Study Units elsewhere in the U.S. (Brumbaugh and others, 2001). Relative to all samples in the USEPA study, the greatest 1997 values from Stations 63 and 514 were about at the $50^{\text {th }}$ percentile, with the caveat that fillet concentrations in the 1997 samples would probably have been higher than those in whole fish. Mercury was among the eight elements associated with the combustion of fossil fuels for which Van Metre and others (1997) reported increasing concentrations in sediment cores from Amistad Reservoir. Thus, and in contrast to most other persistent contaminants, elevated $\mathrm{Hg}$ concentrations in predatory fish (and attendant consumption advisories) remain in effect in the RGB and throughout the U.S.

Overt toxicity in adult fish is usually not associated with the $\mathrm{Hg}$ concentrations now typically encountered in the wild; however, in laboratory studies behavioral effects have been documented in fish containing 0.7-5.4 $\mu \mathrm{g} / \mathrm{g}$ of total $\mathrm{Hg}$ (whole fish) (Kania and O'Hara, 1974; Wiener and Spry, 1996).

Jarvinen and Ankley (1999) reviewed laboratory studies evaluating the effects of $\mathrm{Hg}$ on reproduction in freshwater fish. Among them were studies that reported reduced reproduction at whole body concentrations of $4.47 \mu \mathrm{g} / \mathrm{g}$ total $\mathrm{Hg}$ in fathead minnows (Snarski and Olson, 1982) and $9.4 \mu \mathrm{g} / \mathrm{g}$ in secondgeneration brook trout (Salvelinus fontinalis) (McKim and others, 1976). Hatching success and embryo survival may be affected by maternally transferred $\mathrm{Hg}$; these parameters were negatively correlated with total $\mathrm{Hg}$ in wild walleye containing concentrations similar to those in fish from the RGB (Fig. 3) and MRB (Schmitt and others, 2002c). Consequently, the thresholds for behavioral and reproductive effects are probably much lower than the $\sim 5 \mu \mathrm{g} / \mathrm{g}$ total $\mathrm{Hg}$ threshold for toxicity in adult fish (Wiener and others, 2002; Wiener and Spry, 1996).

In wildlife, dietary total $\mathrm{Hg}$ concentrations as low as $0.3 \mu \mathrm{g} / \mathrm{g}$ have been associated with reproductive impairment in common loons (Gavia immer) (Barr, 1986), and reproduction in mallards (Anas platyrhynchos) was affected at concentrations as low as $0.1 \mu \mathrm{g} / \mathrm{g}$ wet-weight (Heinz, 1979). Dietary concentrations of $0.25-1.0 \mu \mathrm{g} / \mathrm{g}$ may also be toxic to piscivorous mammals (studies reviewed by Wolfe and others, 1998). Consequently, guidelines for concentrations in fish to protect piscivorous wildlife range from 0.5 to $1.0 \mu \mathrm{g} / \mathrm{g} \mathrm{ww}$ total Hg (Eisler, 1987; Thompson, 1996); however, values as low as $0.1 \mu \mathrm{g} / \mathrm{g}$ for mammals and $0.02 \mu \mathrm{g} / \mathrm{g}$ for birds have been derived from water quality criteria and bioaccumulation factors (Yeardley and others, 1998). In addition, the previously held belief that Se protects vertebrates from the adverse effects of $\mathrm{Hg}$ (Bäckström, 1969, cited by Wiener and others,
2002; Ganther, 1978; Ganther and others, 1972; Hoffman and Heinz, 1998) has been tempered by findings of Se-enhanced $\mathrm{Hg}$ embryotoxicity in birds (Heinz and Hoffman, 1998). In addition, Se may enhance $\mathrm{Hg}$ accumulation (Cuvin-Aralar and Furness, 1991; Skerfving, 1978). Therefore, although the substantial amounts of Se present in fish from most RGB stations may protect adult birds from toxic effects of $\mathrm{Hg}$, reproductive and other effects may be exacerbated. Total Hg concentrations in largemouth bass from Stations 63 and 514 exceeded $0.3 \mu \mathrm{g} / \mathrm{g}$, and at least one sample from all stations except 516 exceeded $0.1 \mu \mathrm{g} / \mathrm{g}$ (Fig. 3). Caldwell and others (1999) reported total $\mathrm{Hg}$ concentrations in the blood of double-crested cormorants (Phalacrocorax auratus) from Elephant Butte and Caballo reservoirs that were within the range associated with adverse effects in bald eagles, which also nest at both impoundments. As noted previously, $\mathrm{Hg}$ and $\mathrm{Se}$ are also among the contaminants implicated in the reproductive impairment of peregrine falcons in the Big Bend reach of the RG (Mora and others, 2002). In addition, elevated Hg concentrations were reported in aplomado falcon (Falco femoralis) eggs collected in 1996 near Brownsville (Mora and others, 1997) and in other piscivorous birds from the Laguna Madre [studies cited by (Mora and Wainwright, 1997)]. Collectively, our findings and those of the previous investigations cited indicate that $\mathrm{Hg}$ remains a cause for concern in the $\mathrm{RGB}$, as it also does elsewhere in the U.S.

\section{Lead}

Concentrations of $\mathrm{Pb}$ exceeded detection limits (0.03$0.09 \mu \mathrm{g} / \mathrm{g})$ in 29 of 47 samples $(62 \%)$ from eight stations (Table 10). Concentrations ranged from 0.04 to $0.83 \mu \mathrm{g} / \mathrm{g}$, with the maximum occurring in female bass from Station 16 (Fig. 4; Table 10). The only other samples $>0.30 \mu \mathrm{g} / \mathrm{g}$ were from Station 511. Except for Station 16, all geometric station means were $\leq 0.20 \mu \mathrm{g} / \mathrm{g}$ (Table 11). Concentrations of $\mathrm{Pb}$ in channel catfish, bass, and carp were generally similar (average $0.12-0.14 \mu \mathrm{g} / \mathrm{g}$ ) whereas $\mathrm{Pb}$ was below detection limits in all white bass samples (Fig. 4). Differences between stations with the highest (Stations 511, 512, and 513) and the lowest (Stations 63, 65 and 515) concentrations were statistically significant, but only in carp (Table 12).

Temporal differences were also significant; 1997 concentrations in bass from Station 16 were significantly greater than in all previous collections (Table 13). In contrast, all other significant differences reflected lower 1997 concentrations than in the past (Table 13). Concentrations were lower at Stations 63, 64, and 65 than in NCBP collections from 1980-1986 (Schmitt and others, 1999b). Concentrations of $\mathrm{Pb}$ in most 1997 samples from the transboundary portions of the RG were about the same as those reported for 1992-96 by the Binational Study (TNRCC, 1994b; 1997). At Station 16 (RG at Mission, TX), 1997 levels were similar to those in earlier collections except for the one bass sample with a very high concentration. The Binational Study reported an almost identically elevated 


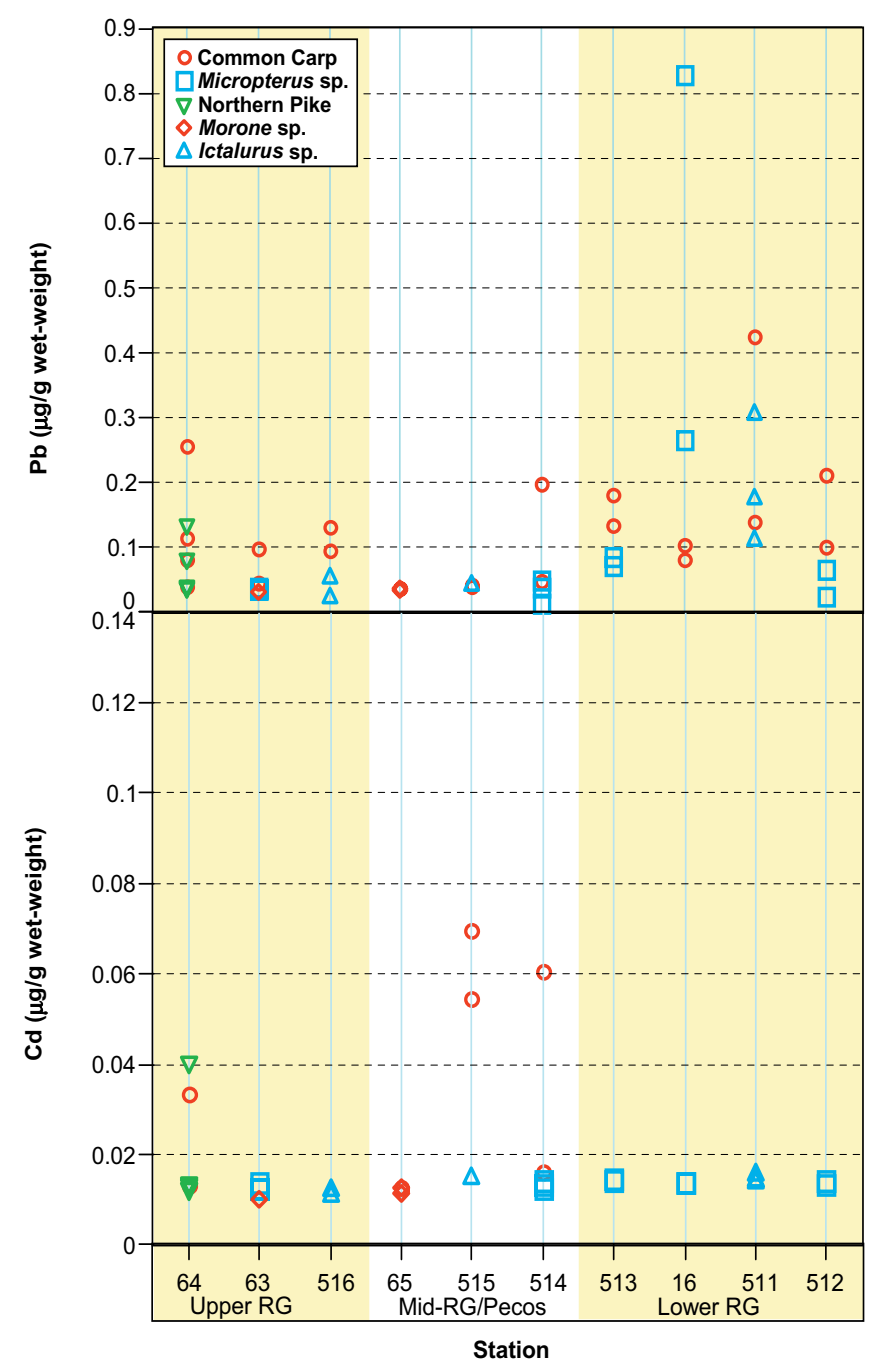

Figure 4. Concentrations of lead $(\mathrm{Pb})$ and cadmium $(\mathrm{Cd})$ in composite samples of whole fish, by station and taxon. Censored values are plotted as $50 \%$ of LOD. Stations are ordered from upstream to downstream and are grouped by sub-basin. See Table 1 for station descriptions and collection dates. Micropterus sp., largemouth or smallmouth bass; Morone sp., white or striped bass; Ictalurus sp., blue or channel catfish.

$\mathrm{Pb}$ concentration $(0.76 \mu \mathrm{g} / \mathrm{g})$ in whole largemouth bass collected from a nearby site in 1992 (TNRCC, 1994b), and Davis and others (1995) reported a level of $0.41 \mu \mathrm{g} / \mathrm{g}$ in one sample of hardhead catfish (Arius felis) from the AC downstream of Harlingen, and concentrations of 1.0-1.8 $\mu \mathrm{g} / \mathrm{g}$ were reported in fillet samples of several species obtained from the Laguna Madre during the 1980s [unpublished TDH data summarized by Mora (2001)]. Concentrations were greater $(1.6 \mu \mathrm{g} / \mathrm{g})$ in blue tilapia (Oreochromis aurea) from a resaca along the lower RG that receives municipal wastes and urban runoff (Mora and others, 2001) than any recent values for fish from either the RG or AC. Concentrations of this magnitude have previously been reported only from sites contaminated by smelters and mine tailings (Schmitt, 2004; Schmitt and others, 2002a; Schmitt and others, 1993). Collectively, these data indicate inputs of anthropogenic $\mathrm{Pb}$ in the lower RGB. However, it should also be noted that sporadically high concentrations may reflect the heterogeneous distribution of $\mathrm{Pb}$ within the fish; $\mathrm{Pb}$ accumulates in hard tissues such as bone and scales, and small pieces of these tissues in the small volume of material from each sample digested and analyzed can profoundly affect measured concentrations (May and McKinney, 1981; Schmitt and Finger, 1987). In the upper RGB, Pb is among the contaminants detected by NAWQA at elevated concentrations in fish (liver samples) and other media obtained in 1992-93 at sites below the Creede, Colorado mining district (Carter and Anderholm, 1997; Levings and others, 1998), but 1997 concentrations in samples from Station 64 (RG at Alamosa, CO), which is downstream from this district, were not elevated (Fig. 4). In addition, $\mathrm{Pb}$ was the only one of the eight elements associated with the combustion of fossil fuels for which Van Metre and others (1997) reported decreasing concentrations in sediment cores from Amistad Reservoir, but only in the Devil's River arm of the reservoir. Concentrations also declined in sediment cores from Llano Grande Lake for the period 1989-2001 (Mahler and Van Metre, 2002).

Because $\mathrm{Pb}$ does not bioaccumulate it represents a hazard to lower trophic level organisms; its presence in fish usually does not represent a threat to piscivorous wildlife (Henny and others, 1994; Henny and others, 2000). It may be associated with harmful effects in the fish, however. Several $\mathrm{Pb}$ studies were included in the recent, comprehensive review by Jarvinen and Ankley (1999). Among these was Holcombe and others (1976), which determined that $\mathrm{Pb}$ concentrations of $0.4 \mu \mathrm{g} / \mathrm{g}$ were associated with reduced hatchability in third generation brook trout embryos. Holcombe and others (1976) also reported reduced growth at various life stages in third generation brook trout at whole-body concentrations of $4.0-8.8 \mu \mathrm{g} / \mathrm{g}$. Effects on heme synthesis in fish have been associated with carcass $\mathrm{Pb}$ concentrations exceeding $1.0 \mu \mathrm{g} / \mathrm{g}$ and varying indirectly with Zn burden (Dwyer and others, 1988; Schmitt and others, 1984; Schmitt and others, 1993). Concentrations of $\mathrm{Pb}$ in the female bass from Station 16 approached this latter value and exceeded the lowest toxicity thresholds of Holcombe and others (1976), but all others were much lower.

\section{Cadmium}

Concentrations of $\mathrm{Cd}$ exceeded detection limits (0.02$0.03 \mu \mathrm{g} / \mathrm{g}$ ) in only $28 \%$ of the samples from $60 \%$ of the stations sampled (Table 10). The maximum concentration (in female carp from Station 64) was $0.12 \mu \mathrm{g} / \mathrm{g}$ (Fig. 4; Table 10 ), and all geometric station means were $<0.05 \mu \mathrm{g} / \mathrm{g}$ (Table 11). Concentrations in carp generally exceeded those in other taxa (Fig. 4). Among-station differences were statistically significant in carp, but not in other taxa; concentrations were significantly greater at Stations 16, 63, and 515, and 516 than at Stations 65 and 511-514 (Table 12). Concentrations in RGB carp were similar to those from agricultural areas of the 
MRB (Schmitt, 2002b) and the RRN (Goldstein and DeWeese, 1999). In contrast, carp from sites in the MRB affected by mining and industrial sources contained 0.20 to $>0.50 \mu \mathrm{g} / \mathrm{g}$ (Schmitt, 2002b). Although some temporal differences were also statistically significant (Table 13), concentrations of $\mathrm{Cd}$ in NCBP fish from the RG were also comparatively low in the past and no long-term trends were evident; all 1980-86 concentrations were $<0.13 \mu \mathrm{g} / \mathrm{g}$ and most were $<0.10 \mu \mathrm{g} / \mathrm{g}$ (Schmitt and others, 1999b). Concentrations in the 1997 samples were similar to most of those reported by the Binational Study (TNRCC, 1994b; 1997) and by Davis and others (1995) for the transboundary portions of the RG and AC. Cadmium was among the elements detected by NAWQA at elevated concentrations in 1992-93 fish (liver samples) and other matrices from the RG below the Creede, Colorado mining district (Carter and Anderholm, 1997; Levings and others, 1998), which is upstream of Station 64. As noted, the 1997 maximum concentration $(0.12 \mu \mathrm{g} / \mathrm{g})$ occurred at this site (Fig. 4 ), but this is still relatively low compared with other areas affected by mining and industry [compare to Schmitt, 2004; Schmitt and others, 2002c)]. Concentrations were $\pm 0.34 \mu \mathrm{g} / \mathrm{g}$ in all carp from Elephant Butte Reservoir and the RG in New Mexcio analyzed by Ong and others (1991).

Birds and mammals are comparatively resistant to $\mathrm{Cd}$; dietary toxicity thresholds in the studies reviewed by Eisler (1985) were $>100 \mu \mathrm{g} / \mathrm{g}$. Nevertheless, Eisler (1985) suggested that a Cd concentration of $2 \mu \mathrm{g} / \mathrm{g}$ in fish is evidence of contamination, that $5 \mu \mathrm{g} / \mathrm{g}$ is potentially life-threatening to the fish, and that $13-15 \mu \mathrm{g} / \mathrm{g}$ is a threat to higher trophic levels. The review by Jarvinen and Ankley (1999) cited only one laboratory study that evaluated the effects of $\mathrm{Cd}$ exposure relative to whole-body concentrations in fish; levels $>2.8 \mu \mathrm{g} / \mathrm{g}$ were associated with decreased spawning and number of embryos produced in flagfish (Jordanella floridae) (Spehar, 1976). All 1997 Cd concentrations were below these benchmarks (Fig. 4). However, recent studies have shown that $\mathrm{Cd}$ can act as an estrogen mimic in rats (for example, Johnson and others, 2003), indicating that reproductive effects in fish and wildlife may occur at exposure levels previously believed to be safe.

\section{Zinc}

Zinc was detected in all samples; concentrations were 11.1-83.6 $\mu \mathrm{g} / \mathrm{g}$, with the maximum occurring in female carp from Station 511 (Fig. 5; Table 10). The range of concentrations and the geometric mean values were similar for all stations (Fig. 5; Table 11). As in 1980-86, bass from Stations 16 and 63 and one white bass sample from Station 65 contained 10-20 $\mu \mathrm{g} / \mathrm{g}$ whereas 1997 concentrations in carp were uniformly $>40 \mu \mathrm{g} / \mathrm{g}$ (Fig. 5). Concentrations in 1997 carp from the RGB were similar to those collected in 1992 from the RRN (Goldstein and DeWeese, 1999) and in the 1980s from the RG in New Mexico (Ong and others, 1991); however, they were lower than 1995 concentrations in carp from many sites in the MRB (Schmitt and others, 2002c). Differences among

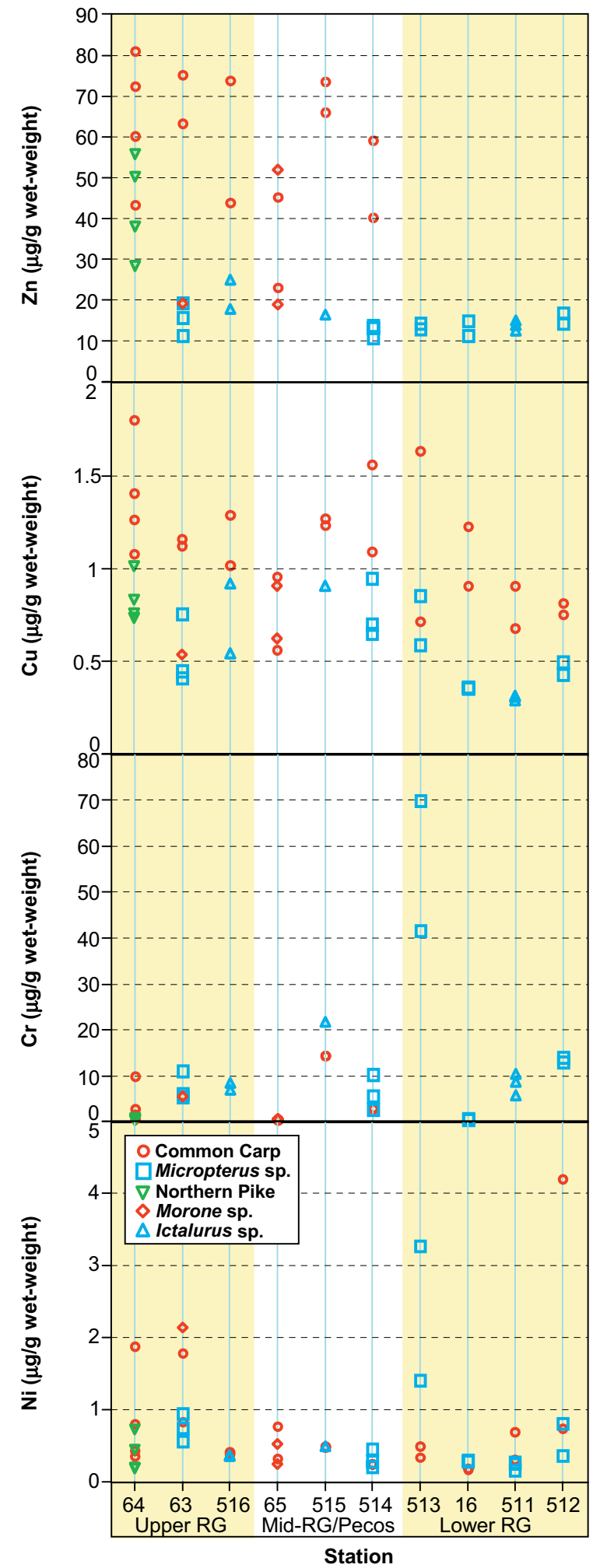

Figure 5. Concentrations of zinc (Zn), copper (Cu), chromium (Cr), and nickel (Ni) in composite samples of whole fish, by station and taxon. Censored values are plotted as $50 \%$ of LOD. Stations are ordered from upstream to downstream and are grouped by subbasin. See Table 1 for station descriptions and collection dates. Micropterus sp., largemouth or smallmouth bass; Morone sp., white or striped bass; Ictalurus sp., blue or channel catfish. 
stations were statistically significant only for carp; Zn concentrations were significantly greater at Stations 16, 63, 511, and 515 than elsewhere (Table 12).

Overall, $1997 \mathrm{Zn}$ concentrations in the transboundary portions of the RGB paralleled those reported for 1992-96 by the Binational Study (TNRCC, 1994b; 1997) and by Davis and others (1995). The only significant temporal changes were in white bass from Station 65; concentrations were about twofold greater in 1997 than in previous collections (Table 13). Station 64 was again difficult to compare temporally because of species changes, but relative to other stations sampled, $\mathrm{Zn}$ concentrations were about the same as or only slightly greater than those in comparable species from other locations. Zinc was among the elements detected at elevated concentrations in fish (liver samples) and other media by NAWQA in 199293 samples from the upper RG below the Creede, Colorado mining district (Carter and Anderholm, 1997; Levings and others, 1998), upstream of Station 64. Zinc was also among the eight elements associated with the combustion of fossil fuels for which Van Metre and others (1997) reported increasing concentrations in sediment cores from Amistad Reservoir, but concentrations in cores from Llano Grande Lake did not change appreciably from 1989 to 2001 (Mahler and Van Metre, 2002).

In life-cycle (larvae-to-adult) studies with $\mathrm{Zn}$ the growth and survival of American flagfish (Jordanella floridae), a cyprinid, were affected at concentrations of 40-64 $\mu \mathrm{g} / \mathrm{g}$ [Spehar, 1976 as cited by Jarvinen and Ankley, 1999]. These concentrations are within the range of those commonly encountered in wild carp but greater than levels typical for other fishes (Schmitt and others, 1999b). In the RGB, only concentrations in carp exceeded the threshold values (Fig. 5; Table 12), so it is unlikely that either fish or higher trophic level organisms were adversely affected by Zn (Eisler, 1993).

\section{Copper}

Copper was detected in all samples at concentrations of $0.29-1.80 \mu \mathrm{g} / \mathrm{g}$, with the maximum occurring in female carp from Station 64 (Fig. 5; Table 10). Concentrations $>1.5 \mu \mathrm{g} / \mathrm{g}$ were also present in carp from Stations 513 and 514 (Fig. 5). All geometric station means were $<1.2 \mu \mathrm{g} / \mathrm{g}$ (Table 11). Differences among stations were statistically significant only in catfish and bass (Table 12). In catfish, $\mathrm{Cu}$ concentrations were significantly greater at Station 516 than at Station 511; and in bass concentrations at Station 514 exceeded those at Station 16 (Table 12). Concentrations in 1997 samples from the transboundary portions of the RGB were similar to most 1992-96 values reported for whole fish by the Binational Study (TNRCC, 1994b; 1997) and by Davis and others (1995). Exceptions were 1996 concentrations of $3.7 \mu \mathrm{g} / \mathrm{g}$ in white bass and $2.4 \mu \mathrm{g} / \mathrm{g}$ in largemouth bass from sites near Brownsville (TNRCC, 1997), which exceeded all 1997 concentrations (Fig. 5). All recent RGB concentrations (1992-97) were within the range of values reported for whole fish of the same species from the MRB (Schmitt and others, 2002c) and the RRN (Goldstein and DeWeese, 1999), and the RG in New Mexico (Ong and others, 1991) however.

Concentrations of $\mathrm{Cu}$ in fish from the RGB collected in 1997 were generally similar to those reported for 1980-86 by the NCBP (Schmitt and others, 1999b), and few temporal differences were statistically significant (Table 13). The only exceptions were downward trends at Station 65; 1997 concentrations carp were significantly lower than in 1986, and 1997 concentrations in white bass were lower than in both 1978 and 1986, when they were especially high (Table 13). Except for some elevated concentrations in brown trout in the past (Schmitt and others, 1999b), the ranges of $\mathrm{Cu}$ concentrations were similar in 1980-86 and 1997 at Station 64. Copper was among the elements detected at elevated concentrations by NAWQA in 1992-93 samples of fish (liver samples) and other media collected from the RG below the Creede, Colorado mining district (Carter and Anderholm, 1997; Levings and others, 1998), upstream of Station 64. Cu was also among the eight elements associated with the combustion of fossil fuels for which Van Metre and others (1997) reported increasing concentrations in sediment cores from Amistad Reservoir, but concentrations in cores from Llano Grande Lake did not change appreciably from 1989 to 2001 (Mahler and Van Metre, 2002).

Copper concentrations in brown trout collected by the NCBP at Station 64 increased steadily from $1.26 \mu \mathrm{g} / \mathrm{g}$ in 1978 (first year that $\mathrm{Cu}$ was measured) to $5.72 \mu \mathrm{g} / \mathrm{g}$ in 1986 (Schmitt and others, 1999b). On a dry-weight basis, the greatest of these concentrations $(10-22 \mu \mathrm{g} / \mathrm{g})$ were within the range reported for this species obtained from mining-contaminated sites in Montana in which biological effects were documented (Farag and others, 1995). Brown trout were not collected at Station 64 in 1997, but the 1997 concentrations in northern pike and carp were all $<2.0 \mu \mathrm{g} / \mathrm{g}$ (Fig. 5).

The ecological relevance of the $1997 \mathrm{Cu}$ concentrations is difficult to judge because few studies linking whole-body concentration to effects on fish have been conducted. Of those reviewed by Jarvinen and Ankley (1999), only the work of Stouthart and others (1996) was potentially relevant; these authors determined that $\mathrm{Cu}$ concentrations of $11.1-11.7 \mu \mathrm{g} / \mathrm{g}$ were associated with reduced survival of carp larvae, and concentrations of $42 \mu \mathrm{g} / \mathrm{g}$ reduced egg survival. These concentrations are at least 10-fold greater than levels encountered in RG fish. No criteria are available against which to evaluate risks of $\mathrm{Cu}$ in fish to wildlife (Eisler, 1997).

\section{Chromium and Nickel}

Concentrations of $\mathrm{Cr}$ and $\mathrm{Ni}$ were not determined by the NCBP (Schmitt and others, 1999b). Although they were measured as part of the 1995 MRB BEST project, they were not reported (Schmitt and others, 2002c). Nevertheless, results for $\mathrm{Cr}$ and $\mathrm{Ni}$ are presented here because of interest in the effects of these metals on wildlife [for example, Outridge 
and Scheuhammer, 1993] and because they are released to the RG from metal plating sites in El Paso (Appendix Table 1) and from the combustion of fossil fuels; both $\mathrm{Cr}$ and $\mathrm{Ni}$ were among the eight elements associated with the combustion of fossil fuels for which Van Metre and others (1997) reported increasing concentrations in sediment cores from Amistad Reservoir, but concentrations in cores from Llano Grande Lake did not change appreciably from 1989 to 2001 (Mahler and Van Metre, 2002). We detected $\mathrm{Cr}$ in all 1997 samples at concentrations of $0.4-71.8 \mu \mathrm{g} / \mathrm{g}$, with the maximum occurring in male carp from Station 63 (Fig. 5; Table 10). Comparatively high concentrations (40-70 $\mu \mathrm{g} / \mathrm{g}$ ) also characterized both samples of largemouth bass from Station 513 (Fig. 5). These maxima are about 100-fold greater than most other recently reported concentrations in fish from the RGB (Davis and others, 1995; Ong and others, 1991; Roy and others, 1992; TNRCC, 1994b; 1997), and most 1997 concentrations were 10 -fold greater. Geometric mean concentrations were $>4.0$ $\mu \mathrm{g} / \mathrm{g}$ at Stations 63, 511, 512, 513 (maximum, $28.5 \mu \mathrm{g} / \mathrm{g}$ ), 514, 515, and 516 (Table 11). According to Eisler (1986), Cr concentrations $>4 \mu \mathrm{g} / \mathrm{g}$ dry-weight (about $1.0 \mu \mathrm{g} / \mathrm{g}$ wetweight) in the tissues and organs of fish and wildlife indicate environmental contamination, but the significance of these concentrations is not clear. Most 1997 samples and station means exceeded $1.0 \mu \mathrm{g} / \mathrm{g}$ (Fig. 5; Table 11). Whole-body $\mathrm{Cr}$ concentrations in carp from the mostly rural RRN averaged only about $0.8 \mu \mathrm{g} / \mathrm{g}$; concentrations in liver were lower (mean $=0.6 \mu \mathrm{g} / \mathrm{g})$ whereas those in muscle were higher $($ mean $=1.0$ $\mu \mathrm{g} / \mathrm{g})($ Goldstein and DeWeese, 1999). A recent review of the literature (Jarvinen and Ankley 1999) found no studies linking whole-body $\mathrm{Cr}$ concentrations to survival or growth effects in freshwater fishes.

All RGB samples also contained detectable Ni (Table 10). Concentrations were $0.2-4.2 \mu \mathrm{g} / \mathrm{g}$, with the maximum occurring in male carp from Station 512 (Fig. 5; Table 10). One sample of largemouth bass from Station 513 contained substantially more Ni than most others $(3.2 \mu \mathrm{g} / \mathrm{g}$; Fig 5). As was also true for $\mathrm{Cr}$, these maxima are greater (by about 10-fold) than most recent values reported by other RGB studies (Davis and others, 1995; TNRCC, 1994b; 1997). Geometric station means were greatest for Stations 63, 512, and 513 (0.95-1.05 $\mu \mathrm{g} / \mathrm{g}$ ); all others were $<0.5 \mu \mathrm{g} / \mathrm{g}$ (Fig 5; Table 11). These means are also many-fold greater than the mean whole-body Ni concentration in carp $(0.14 \mu \mathrm{g} / \mathrm{g})$ from the mostly rural RRN (Goldstein and DeWeese, 1999). Nickel was among a large group of mining-derived metals detected at elevated concentrations in water, but not in sediments or fish, from the upper RG in 1992-93 by NAWQA (Carter and Anderholm, 1997; Levings and others, 1998). Criteria for the protection of fish and piscivorous wildlife have not yet been established for $\mathrm{Ni}$ in fish, and no studies linking whole-body concentrations and effects were reviewed by Jarvinen and Ankley (1999).

Data for additional metals (Al, B, Ba, Be, Fe, Mg, Mn, $\mathrm{Mo}, \mathrm{Sr}, \mathrm{V})$, along with all other data from this study, are available at <http://www.cerc.usgs.gov/data/data.htm>. Of these, $\mathrm{B}, \mathrm{Be}$, and Mo were below detection limits in all samples.

\section{Organochlorine Chemical Residues}

\section{DDT and its Primary Metabolites}

Although DDT use in the United States was curtailed in 1972, it continued to be used for mosquito control in Mexico through 1997 (Environmental Health Perspectives, 1997; Mora and others, 1997). In addition, residues of this persistent organochlorine insecticide and its metabolites remain present in the environment from historical use and as a consequence of atmospheric transport from elsewhere in the world. In U.S. rivers, elevated concentrations persist in cotton-growing areas and near former sites of production and formulation (Schmitt and others 2002c). At the RGB sites sampled in 1997, concentrations of $p, p$ '-DDT, the parent compound, were below the detection limit $(<0.01 \mu \mathrm{g} / \mathrm{g})$ in all samples (Table 15), indicating the presence of only weathered material from historical use (Aguillar, 1984; Schmitt and others, 1999b). Further evidence of weathering is that on average $p, p$ '-DDE (DDE), the most persistent metabolite, constituted $94.3 \%$ of the total p,p'- homologs detected (Fig. 6). Residues of DDE remained widespread in the RGB, however; they were detected $(>0.01$ $\mu \mathrm{g} / \mathrm{g})$ in 43 of the 47 samples analyzed and in at least one sample from all stations (Fig. 7; Table 15). The greatest concentrations (individual samples and geometric station means) were from Stations 16 and 511, in the lower RGB (Figs. 6 and 7; Tables 15 and 16). Individual samples containing comparatively high concentrations $(\geq 0.50 \mu \mathrm{g} / \mathrm{g})$ included carp from Station $16(0.50 \mu \mathrm{g} / \mathrm{g})$ and carp and channel catfish from Station 511 (range 0.67-1.60 $\mu \mathrm{g} / \mathrm{g}$; Fig. 7). Concentrations of DDE differed significantly among stations in all taxa, and there was a general gradient from upstream to downstream; levels in fish from sites in the upper parts of the RGB were generally low relative to those from downstream stations (Fig. 7; Table 12). The exception was Station 512 (RG at Brownsville), where concentrations were also low (Fig. 7). Whole fish from the upper RGB sampled in 1992-93 by NAWQA contained traces of DDE (Carter and Anderholm, 1997; Levings and others, 1998), as did several 1997 samples from Stations 63 and 64 (Fig. 7; Table 15). Residues of $p$,p'-DDE were also detected in SPMDs from four of the six transboundary RG sites sampled by Moring (1999) in July-August 1997.

Environmental residues of $p, p$ '-DDD result from the anaerobic metabolism of $p, p$ '-DDT and to the historical use of the insecticide Rhothane ${ }^{\circledR}$ (Table 3). In 1997 p,p'-DDD represented $5.7 \%$ (mean) of total DDT and was detected $(>0.01 \mu \mathrm{g} / \mathrm{g})$ in 23 of 47 samples from six stations (Table 15). Concentrations were uniformly low, however; all samples contained $\leq 0.084 \mu \mathrm{g} / \mathrm{g}$ (Table 15) and all geometric station means were $<0.05 \mu \mathrm{g} / \mathrm{g}$ (Table 16). Residues of $p$, $p$ '-DDD were detected in SPMDs from only one of the six transboundary RG sites (downstream of Hildalgo) sampled by Moring (1999) in July-August 1997.

In the upper RG, total DDT concentrations at NCBP 


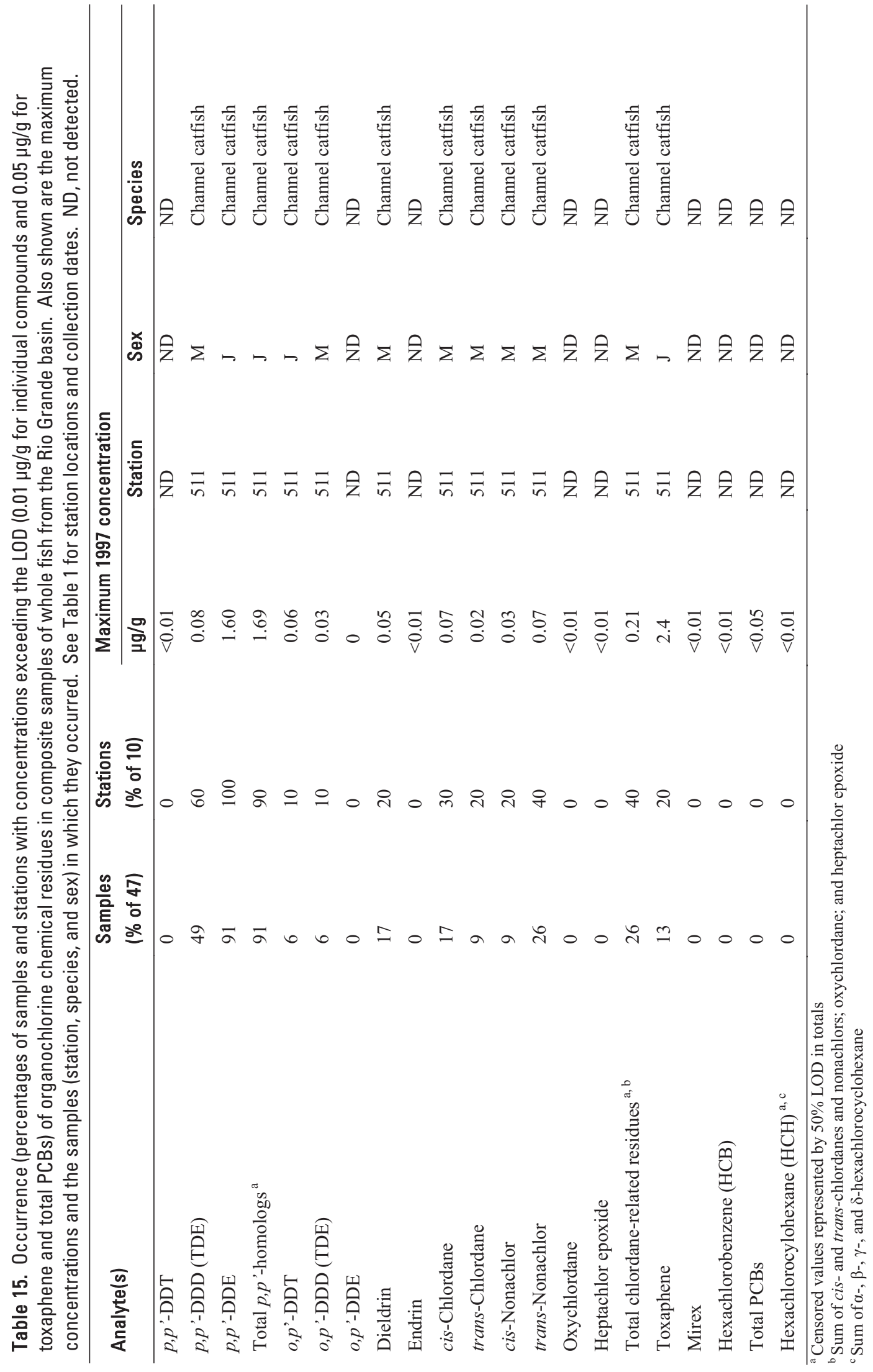




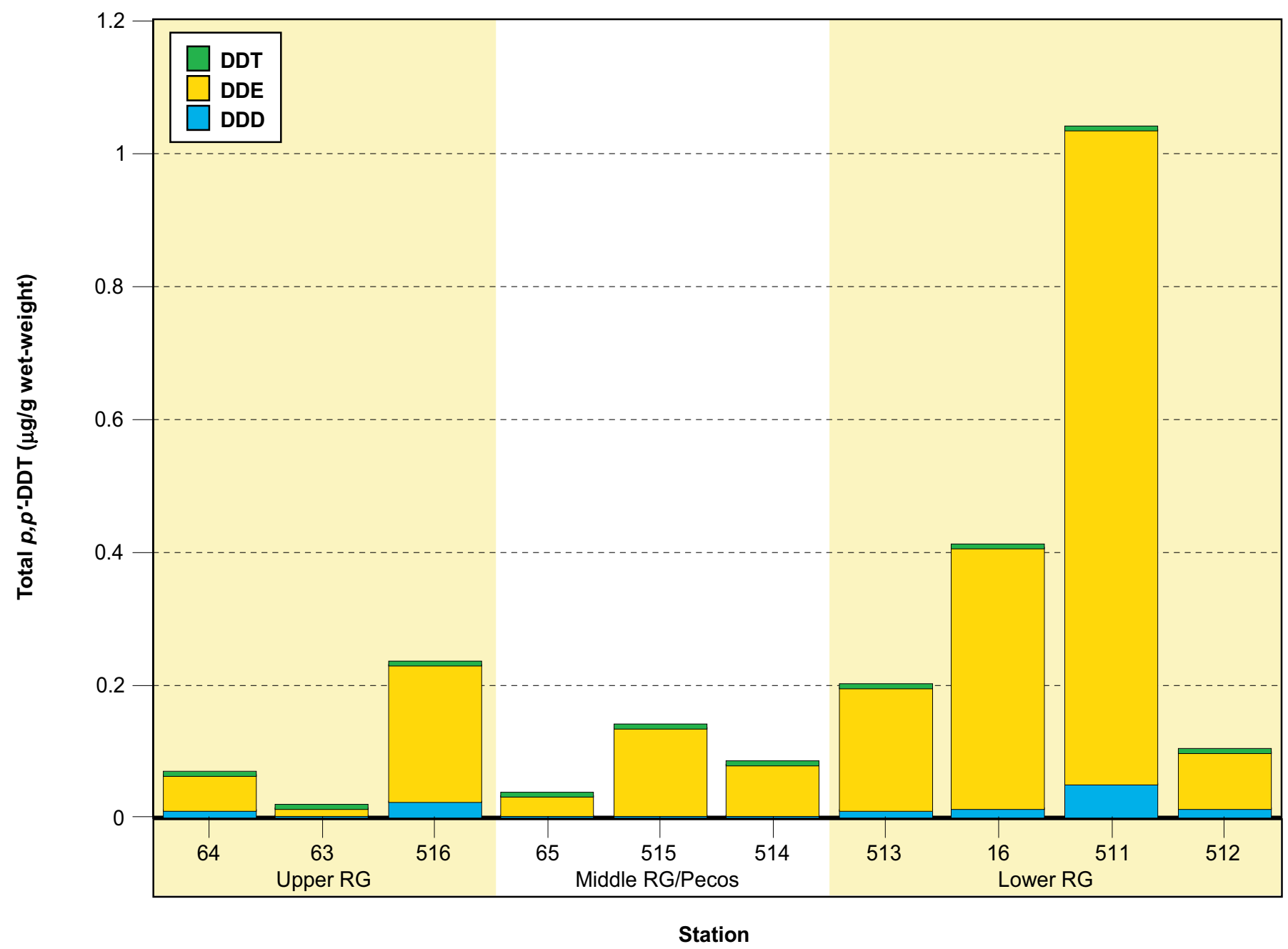

Figure 6. Geometric mean concentrations of $p, p^{\prime}-\mathrm{DDT}, \mathrm{DDE}$, and DDD in composite samples of whole fish, by station. (Note: censored values are represented by 50\% LOD in the computation of means and totals but are not shown). Stations are ordered from upstream to downstream and are grouped by sub-basin. See Table 1 for station descriptions and collection dates.

Stations 63, 64, and 65 were historically $\leq 0.2 \mu \mathrm{g} / \mathrm{g}$; most Station 63 (RG at Elephant Butte Reservoir) concentrations were $<0.02 \mu \mathrm{g} / \mathrm{g}$ (Schmitt and others, 1999b). This trend continued through 1997 (Fig. 6). Ong and others (1991) reported only traces of DDE in samples of biota and sediments collected during the 1980s from the RG in New Mexico and Bosque del Apache NWR. Concentrations of DDT in recently deposited sediments (1990s) from Elephant Butte Reservoir were also comparatively low, having declined steadily since the $1970 \mathrm{~s}$ (Van Metre and others, 1997).

Concentrations of DDT were historically elevated in parts of the middle RG. Quillback carpsuckers (Carpiodes carpio) collected from the RG near Las Cruces, New Mexico in 1976 contained $2.7 \mu \mathrm{g} / \mathrm{g}$ of DDE (White and others, 1983), and carp collected from several sites near Las Cruces in 1987 contained 1.3-6.3 (Roy and others, 1992). Western kingbirds (Tyrannus verticalis) collected in 1987 from some sites in this area also contained 1.4-5.1 $\mu \mathrm{g} / \mathrm{g}$ (Roy and others, 1992). Fish from the Big Bend region collected during the 1980s contained as much as $8.7 \mu \mathrm{g} / \mathrm{g}$ of $p$,p'-DDE (Mora and others, 2002; Mora and Wainwright, 1998). Concentrations were also elevated in peregrine falcon eggs from the Big Bend area, which may have affected their reproduction; and in northern roughwinged swallows (Stelgidopterys serripennis), which forage over the river on emergent aquatic insects (Irwin, 1989; Mora and others, 2002). Concentrations of DDE in fish collected in 1997 from Station 515 and 516, which are respectively below and above Big Bend, were 0.10-0.32 $\mu \mathrm{g} / \mathrm{g}$ (Figs. 6 and 7). Relative to the 233 samples analyzed nationwide by NAWQA, the greater of these concentrations approached the $95^{\text {th }}$ percentile (Wong and others, 2000). However, sediment cores from Amistad International Reservoir revealed comparatively low concentrations of total DDT and $p, p$ '-DDE in sediments deposited since 1970 (Van Metre and others, 1997).

The lower RGB has a long history of contamination by DDT and its metabolites, but the trend in concentration has been uniformly downward; concentrations of DDE declined significantly in at least one taxon at all four NCBP stations 


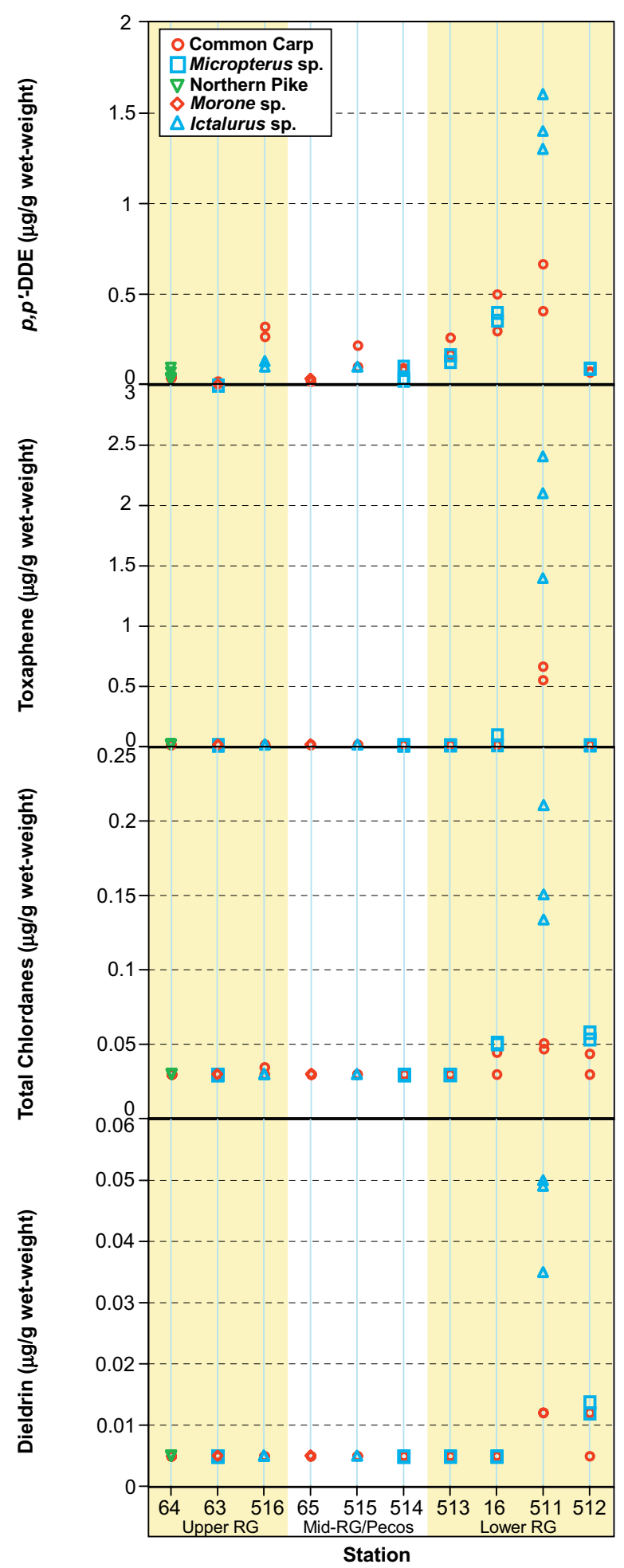

Figure 7. Concentrations of $p, p^{\prime}-\mathrm{DDE}$, toxaphene, total chlordanes (sum of cis- and trans-chlordanes and nonachlors, heptachlor epoxide, and oxychlordane), and dieldrin in composite samples of whole fish, by station and taxon. Censored values are represented by $50 \%$ of LOD. Stations are ordered from upstream to downstream and are grouped by sub-basin. See Table 1 for station descriptions and collection dates. Micropterus sp., largemouth or smallmouth bass; Morone sp., white or striped bass; Ictalurus sp., blue or channel catfish. sampled in 1997 (Table 13). This finding is consistent with most other recent investigations in the RGB and elsewhere. Relatively high DDE concentrations typified fish collected near the Port of Harlingen (near Station 511) over two decades [1975-1995; (Mora and Wainwright, 1998)]. For example, concentrations of DDE were $>20 \mu \mathrm{g} / \mathrm{g}$ in whole fish and as great as $71 \mu \mathrm{g} / \mathrm{g}$ (mean $=34 \mu \mathrm{g} / \mathrm{g}$ ) in laughing gulls (Larus atricilla) collected from Llano Grande Lake in 1978-79 (White and others, 1983). Concentrations also exceeded $10 \mu \mathrm{g} / \mathrm{g}$ in many samples of fish obtained from the AC near Harlingen in 1978-79 (White and others, 1983). Concentrations remained typically 2-9 $\mu \mathrm{g} / \mathrm{g}$ in fillet samples of many fish species from Llano Grande Lake and the AC during the 1980s [unpublished TDH data summarized by Mora (2001)]. Whole channel catfish obtained from the AC in 1987 also contained $3.2 \mu \mathrm{g} / \mathrm{g}$ of DDE (USEPA, 1992b), about twice the levels in 1997 samples of this species from Station 511 (Figs. 6 and 7). However, by 1994 the arithmetic mean DDE concentration in fish from the AC near the Port of Harlingen had declined to $0.46 \mu \mathrm{g} / \mathrm{g}$ (Davis and others, 1995). Concentrations also continued to decline in Llano Grande Lake sediment cores from 1980 to 2001 (Mahler and Van Metre, 2002). Despite the declines, the TDH has issued a consumption advisory against eating fish from the $\mathrm{AC}$ and other waters near Station 511; DDE is among the contaminants in the advisory (Appendix Table 1). At Station 16 (RG at Mission, TX), the NCBP site geographically closest to Stations 511, 512, and 513, concentrations of total DDT in fish also consistently exceeded 1.0 $\mu \mathrm{g} / \mathrm{g}$, primarily as $p, p^{\prime}-\mathrm{DDE}$, in the past. The geometric mean concentration of total $p, p$ '-DDT at this site was the second highest among all NCBP sites sampled in 1986, and the station mean exceeded the $85^{\text {th }}$ percentile concentration nationwide (Schmitt and others, 1999b). Total DDT concentrations remained comparatively high at this station in 1997 (Fig. 6).

Concentrations of $p, p$ '-DDE in our fish samples from the transboundary portions of the RGB were generally about the same as those reported during the 1990s by the Binational Study (TNRCC, 1994b; 1997) and by Davis and others (1995). In contrast, fish obtained in 1996 from some resacas along the lower RG in Texas and Mexico contained 5-10 $\mu \mathrm{g} / \mathrm{g}$ (Mora and others, 2001). Carp collected in 1997 from resacas and settling basins by Wainwright and others (2001) also contained as much as $2.1 \mu \mathrm{g} / \mathrm{g}$ of $p, p^{\prime}-\mathrm{DDE}$, and the eggs of fish-eating birds from all sites contained DDE residues. In addition, Wainwright and others (2001) noted that concentrations in the eggs of greenback heron (Butorides virescens) tended to increase from west to east (upstream to downstream); eggs from Falcon International Reservoir contained only 0.06-0.28 $\mu \mathrm{g} / \mathrm{g}$ (ww) whereas those from further downstream contained as much as $19.38 \mu \mathrm{g} / \mathrm{g}$. Relative to the $\mathrm{AC}$ and other waters of the lower RGB, 1978-79 DDE concentrations in fish from Falcon and Amistad International Reservoirs were low $[\leq 0.5$ $\mu \mathrm{g} / \mathrm{g}$; White and others (1983)].

Nationally, the greatest DDE concentration detected by USEPA in 1987 samples was $14 \mu \mathrm{g} / \mathrm{g}$ (Kuehl and others, 1994). Relative to all stations sampled by USEPA, the greatest 
1997 concentration $(1.6 \mu \mathrm{g} / \mathrm{g}$ in channel catfish from Station 511) was equivalent to about the $90^{\text {th }}$ percentile (USEPA, 1992a) and also exceeded the $95^{\text {th }}$ percentile concentration based on the 233 samples analyzed nationwide by NAWQA (Wong and others, 2000). Collectively, these findings indicate that although concentrations of residues derived from DDT have declined greatly over the last two decades, substantial quantities remain in the lower RGB as they also do in the cotton-growing regions of the lower MRB (Schmitt and others, 2002c). The 1997 data from the AC along with those of Mora and others (2001) also indicate that pockets of elevated concentrations remain despite lower overall levels relative to the past. Sediment cores from Falcon International Reservoir also revealed declining concentrations in the 1970s followed by stable levels through 1995, indicating continuing low-level inputs (Van Metre and others, 1997).

Concentrations of total DDT in fish $>0.15 \mu \mathrm{g} / \mathrm{g}$ are considered potentially harmful to the brown pelican, a sensitive avian species (Anderson and others, 1975), and wildlife criteria as low as $0.20 \mu \mathrm{g} / \mathrm{g}$ have been proposed (Newell and others, 1987). According to studies reviewed by Blus (1996), concentrations of $1-3 \mu \mathrm{g} / \mathrm{g}$ are potentially hazardous to most piscivorous birds. Studies of fish reviewed by Jarvinen and Ankley (1999) associated toxic effects with whole-body concentrations as low as $0.05 \mu \mathrm{g} / \mathrm{g}$. Other studies indicated lower toxicity; egg survival was reduced in rainbow trout containing $1.27 \mu \mathrm{g} / \mathrm{g}$ of total DDT (Hopkins and others, 1969), and in juvenile green sunfish (Lepomis cyanellus) and pumpkinseed (L. gibbosus) reduced survival occurred at $24 \mu \mathrm{g} / \mathrm{g}$ (Hamelink and others, 1971). In 1997, concentrations of total DDT (mostly DDE) were $>1.0 \mu \mathrm{g} / \mathrm{g}$ in channel catfish from Station 511, and individual samples from Stations 16, 511, 513, and 516 exceeded $0.15 \mu \mathrm{g} / \mathrm{g}$ (Figs. 6 and 7).

Technical DDT contains $o, p$ '-DDT as an impurity (Table 3 ), and residues of this compound and its metabolites also remain widespread (Schmitt and others, 2002c; Schmitt and others, 1999b; Schmitt and others, 1985). Traces of $o, p$ '-DDT $(0.03-0.06 \mu \mathrm{g} / \mathrm{g})$ and $o, p$ '-DDD $(0.02-0.03 \mu \mathrm{g} / \mathrm{g})$ were present exclusively in the three channel catfish samples from Station 511, but no $o, p$ '-DDE residues were detected $(<0.01 \mu \mathrm{g} / \mathrm{g})$ in any samples (Table 15). Although the $o, p$ '- homologs have historically been considered relatively benign, $o, p$ '-DDD is weakly estrogenic (Ackerman and others, 2002; Guillette and others, 1994; Toppari and others, 1995), as are many other pesticides and their metabolites (Tyler and others, 1998). Hence, the total risk to fish and wildlife represented by environmental residues derived from DDT and other organochlorine pesticides no longer used in the U.S. are unknown.

\section{Cyclodiene Insecticides}

\section{Chlordane and Heptachlor}

Chlordane is a mixture of cyclopentadiene-derived compounds that was widely used as a soil insecticide. Concentrations are typically greatest in fish from corn-growing regions, urban areas where termites are present, and near production and formulation facilities (Schmitt, 2002b; Schmitt and others, 1999b). Although chlordane is no longer used in the U.S., it continued to be used for termite control in Mexico through 1997 (Environmental Health Perspectives, 1997). Six chlordane-related components and metabolites were measured in the 1997 samples: cis-chlordane, trans-chlordane, cis-nonachlor, trans-nonachlor, oxychlordane, and heptachlor epoxide (Fig. 8; Table 3). Oxychlordane is a metabolite of cis-chlordane, and heptachlor epoxide is a metabolite of the insecticide heptachlor. Both of the latter are also minor constituents of technical chlordane; environmental residues of heptachlor epoxide derive from insecticidal use of both heptachlor and chlordane.

Total 1997 chlordane concentrations (sum of six components) were greatest in channel catfish from Station 511 (Fig. 7). Concentrations of oxychlordane and heptachlor epoxide were below the LOD $(0.01 \mu \mathrm{g} / \mathrm{g}$ ) in all samples (Fig. 8; Table 15). Concentrations of the other four compounds exceeded the LOD $(0.01 \mu \mathrm{g} / \mathrm{g})$ in fish from four lower RGB stations: 511 , 512, 514, and 16 (Fig. 8; Table 16). Residues of cis-chlordane were detected in channel catfish and carp from Station 511 at concentrations of $0.017-0.073 \mu \mathrm{g} / \mathrm{g}$; the highest concentrations were in channel catfish (Fig. 8; Table 16). Traces $(<0.02$ $\mu \mathrm{g} / \mathrm{g}$ ) were also detected in bass from Station 512 and carp from Station 16 (Fig. 8). Trans-chlordane (0.015-0.022 $\mu \mathrm{g} / \mathrm{g}$ ) and $c i s$-nonachlor $(0.019-0.033 \mu \mathrm{g} / \mathrm{g})$ were also detected in channel catfish from Station 511 (Table 16). Traces of transchlordane were present in carp from Station 512 whereas bass from Station 16 contained traces of cis-nonachlor. Transnonachlor was the most frequently detect chlordane constituent; it was detected $(0.036-0.073 \mu \mathrm{g} / \mathrm{g})$ in 12 of 47 samples from four stations (Table 15). Channel catfish from Station 511 contained the highest concentrations. Concentrations in bass from Stations 16 and 512 were $0.02-0.03 \mu \mathrm{g} / \mathrm{g}$, and other species from Stations 16, 511, 512, and 516 contained traces (0.01-0.02 $\mu \mathrm{g} / \mathrm{g})$. No chlordane components exceeded detection limits $(0.01 \mu \mathrm{g} / \mathrm{g})$ in any 1997 samples from Stations 63, $6465,513,514$, or 515 (Figs. 7 and 8; Table 16).

The 1997 results agree with those of most recent studies. Residues of trans-nonachlor and trans-chlordane were each detected in SPMDs from only one the six transboundary RG sites sampled by Moring (1999) in July-August 1997; both sites were on the lower RG (downstream of Laredo and downstream of Brownsville). Ong and others (1991) reported only traces of chlordane constituents in samples of biota and 


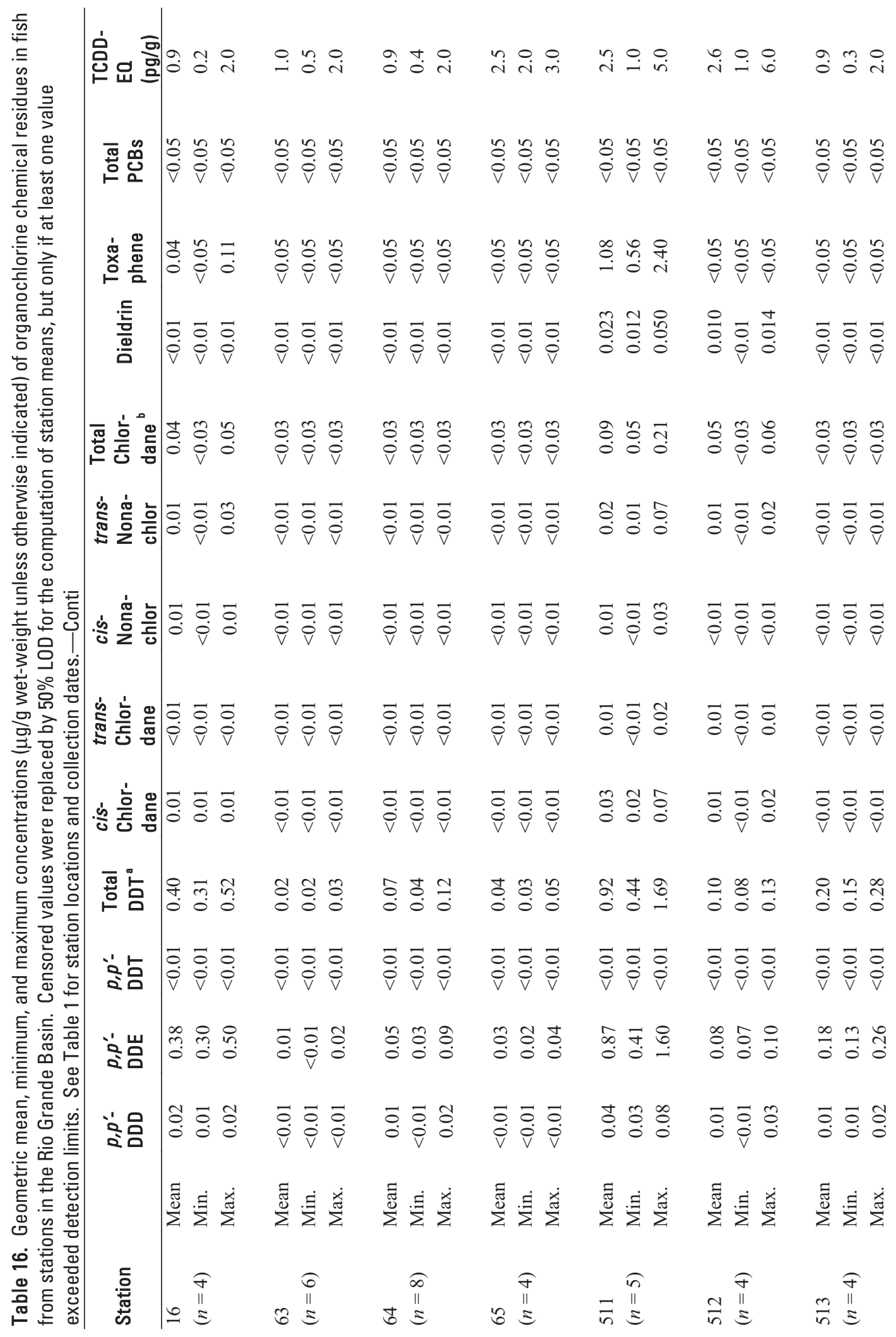




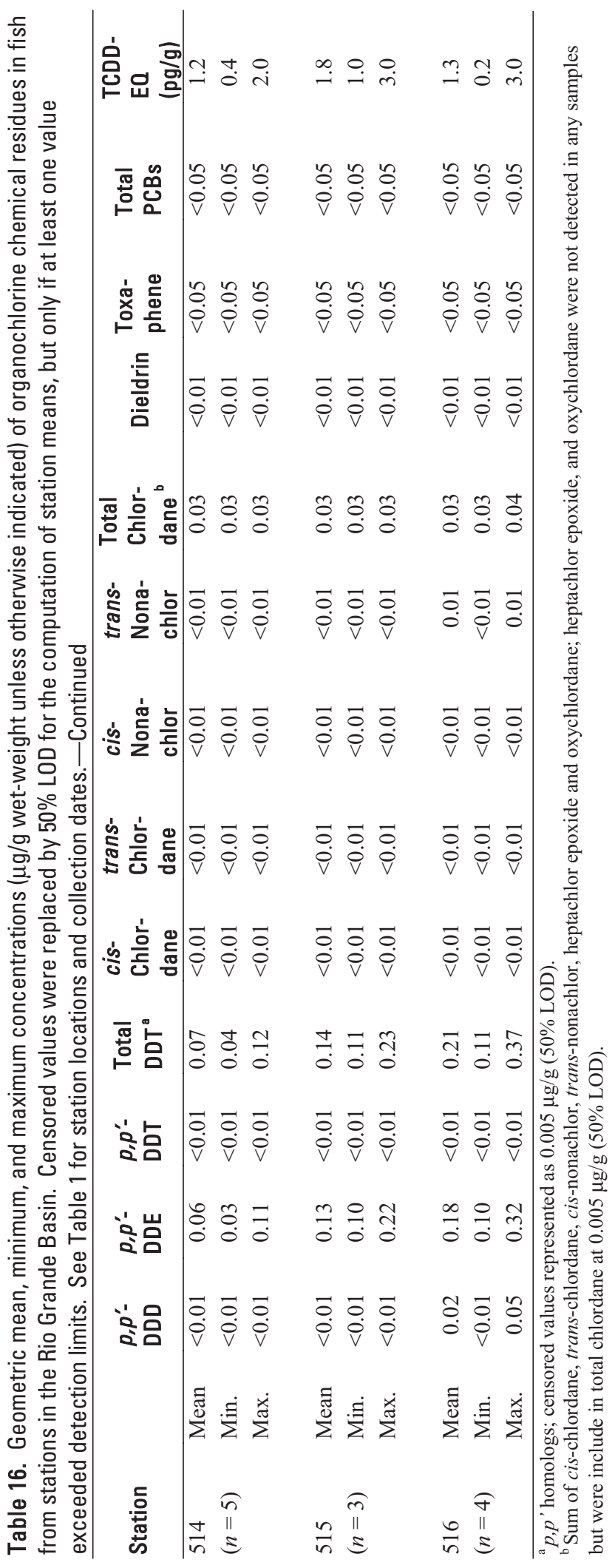

sediments collected during the 1980s from the RG in New Mexico and Bosque del Apache NWR as did fish sampled in 1992-93 from the upper RGB by the NAWQA program (Carter and Anderholm, 1997; Levings and others, 1998). Residues of $0.01-0.03 \mu \mathrm{g} / \mathrm{g}$ were detected in whole fish from some sites in the lower RG sampled in 1992-93 by the Binational Study (TNRCC, 1994b; 1997) and by Davis and others (1995); however, higher concentrations were reported in fish fillets from some of these sites. In contrast, Wainwright and others (2001) found $<0.01 \mu \mathrm{g} / \mathrm{g}$ of trans-nonachlor in 16 carp samples obtained from lower RGB resacas and settling basins in 1997. These latter values were about 10 -fold lower than our 1997 maxima for fish from the lower RG and AC (Table 16). Wainwright and others (2001) also detected trans-nonachlor in the eggs of fish-eating birds from all sites investigated (maximum $=0.15 \mu \mathrm{g} / \mathrm{g}$ wet-weight). Chlordane concentrations of $0.72-0.93 \mu \mathrm{g} / \mathrm{g}$ were reported in fillet samples of several fish species obtained from Llano Grande Lake during the 1980s [unpublished TDH data summarized by Mora (2001)], but 1989-2001 concentrations in sediment cores were uniformly low (Mahler and Van Metre, 2002). Whole carp and white bass fillets obtained in 1987 by USEPA (1992b) from the RG at El Paso contained traces of chlordane components whereas whole channel catfish from the AC contained a total of $0.16 \mu \mathrm{g} / \mathrm{g}$ (sum of five components detected), which is nearly identical to what was present in 1997 samples of this species (Fig. 7). Relative to all 1987 USEPA samples, 1997 chlordane concentrations in channel catfish from Station 511 were equivalent to about the $90^{\text {th }}$ percentile (USEPA, 1992a). Elsewhere, USEPA reported total chlordane concentrations $\geq 1.2 \mu \mathrm{g} / \mathrm{g}$ in fish from the most contaminated sites sampled in 1987(Kuehl and others, 1994; USEPA, 1992a). Chlordane residues in fish from Station 511 were similar in concentration and composition to those obtained in 1995 from agricultural and urban areas of the MRB (Schmitt, 2002b; Schmitt and others, 2002c). Nationally, trans-nonachlor was detected in $33.8 \%$ of the fish samples analyzed by NAWQA; other chlordane components were detected less frequently (Wong and others, 2000). The greatest 1997 concentrations of chlordane components in channel catfish from Station 511 were all less than the $75^{\text {th }}$ percentile concentrations reported by NAWQA (Wong and others, 2000).

Chlordane concentrations at Station 16 peaked at about $0.20 \mu \mathrm{g} / \mathrm{g}$ in 1978 , only two years after NCBP measurements began (Schmitt and others, 1999b). Fish samples from this site typically contained $\leq 0.02 \mu \mathrm{g} / \mathrm{g}$ of cis-chlordane, transchlordane, and cis-nonachlor and $<0.01-0.08 \mu \mathrm{g} / \mathrm{g}$ of transnonachlor. Concentrations in fish from this site have generally declined since the late 1970s (Schmitt and others, 1999b). Elsewhere in the lower RG, much higher concentrations were detected historically; Mora and Wainwright (1997) indicated that concentrations in fish from the Brownsville area peaked in 1976 when levels as great as $15.6 \mu \mathrm{g} / \mathrm{g}$ were reported. At other NCBP sites in the RGB, chlordane concentrations were historically lower than at Station 16. From 1980-86, heptachlor epoxide concentrations were below detection and 


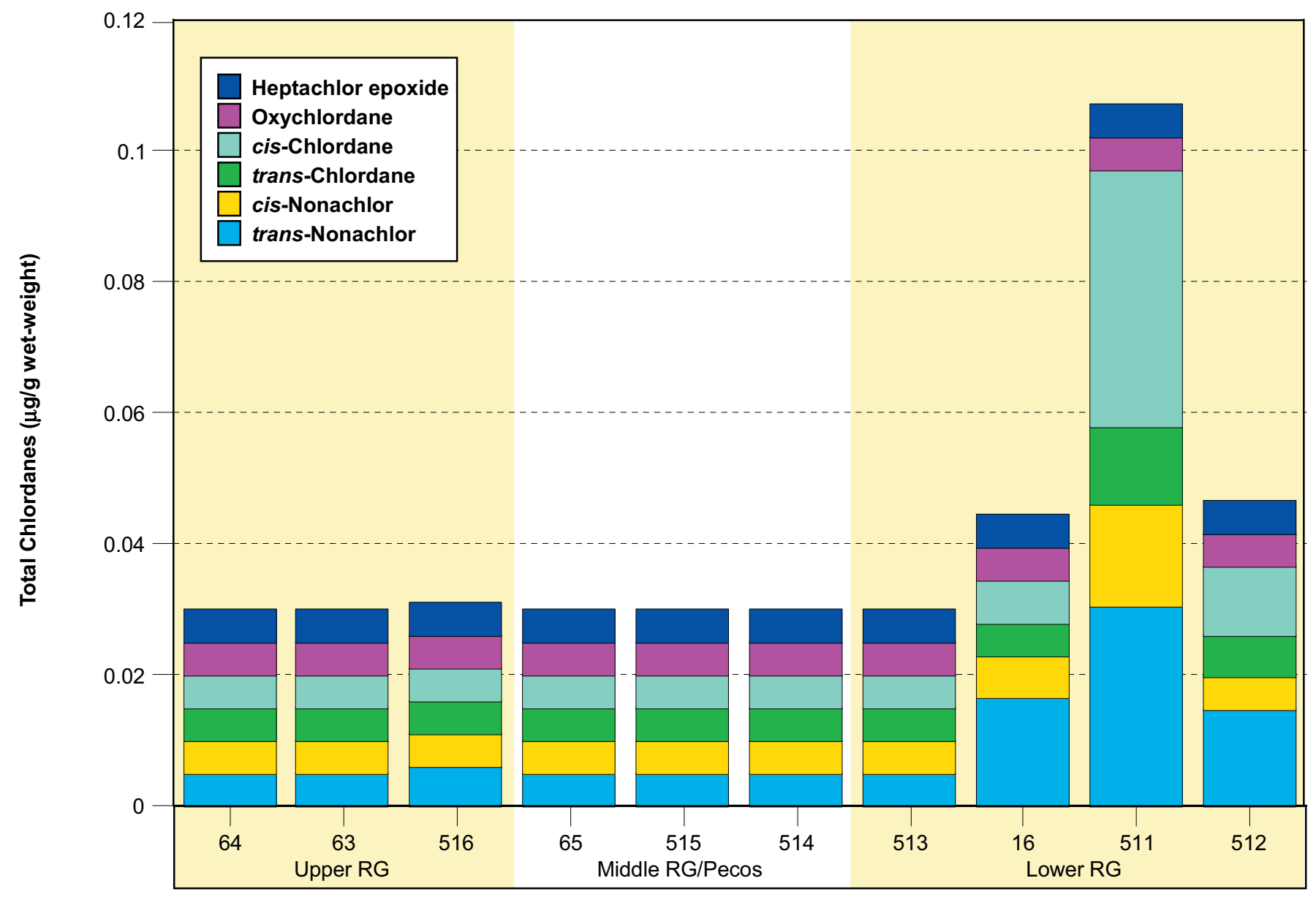

Station

Figure 8. Geometric mean concentrations of chlordane-related compounds (cis- and trans-chlordanes and nonachlors, heptachlor epoxide, and oxychlordane) in composite samples of whole fish, by station. (Note: censored values are represented by 50\% LOD in the computation of means and totals but are not shown). Stations are ordered from upstream to downstream and are grouped by subbasin. See Table 1 for station descriptions and collection dates.

oxychlordane was rarely detected in fish from Stations 16,63 , 64 , and 65 at detection limits of $0.005-0.01 \mu \mathrm{g} / \mathrm{g}$ (Schmitt and others, 1999b). Concentrations of cis-chlordane, trans-chlordane, cis-nonachlor, and trans-nonachlor were all $\leq 0.01 \mu \mathrm{g} / \mathrm{g}$ at Stations 63, 64, and 65 during this period.

As noted, total chlordane concentrations (sum of six components) in 1997 were greatest $(>0.1 \mu \mathrm{g} / \mathrm{g})$ in channel catfish samples from Station 511; other samples did not exceed 0.059 $\mu \mathrm{g} / \mathrm{g}$ (Fig. 7). The geometric mean total chlordane value at Station 511 was $0.098 \mu \mathrm{g} / \mathrm{g}$, more than twice the mean value at Station $512(0.043 \mu \mathrm{g} / \mathrm{g}$; Table 16). In addition, concentrations of cis-chlordane in fish from Station 511 exceeded those of trans-nonachlor (Fig. 8; Table 16), the opposite of what is typical for weathered chlordane residues in fish (Schmitt, 2002b; Schmitt and others, 2002c). This finding suggests comparatively recent chlordane inputs.

Chlordane residues $>0.3 \mu \mathrm{g} / \mathrm{g}$ are of concern for the health of predatory fish and fish-eating birds (Eisler, 1990). Chlordane is also among the contaminants included in the present fish consumption advisory for the AC (Station 511) and nearby waters. Elsewhere in the U.S., residual chlordane from historical use has been implicated in recent wildlife kills (Stansley and Roscoe, 1999), demonstrating the potential of this pesticide mixture to inflict ecological injury despite the fact that it is no longer used.

\section{Dieldrin}

Most environmental dieldrin results from the metabolism of aldrin, which has not been used in the U.S. since 1974.

Dieldrin was detected $(>0.01 \mu \mathrm{g} / \mathrm{g})$ in only $17 \%$ of the samples from two sites (Fig. 7; Table 15). Concentrations were greatest $(0.035-0.05 \mu \mathrm{g} / \mathrm{g})$ in the channel catfish samples (male, juvenile, and female) from Station 511 (Fig. 7). The other two samples from Station 511 (carp) and three of the four samples from Station 512 (carp and largemouth bass) also contained traces $(<0.015 \mu \mathrm{g} / \mathrm{g}$; Fig. 7$)$. 
Historically, dieldrin concentrations were below detection $(<0.01 \mu \mathrm{g} / \mathrm{g})$ at Stations 63, 64 and 65. In contrast, concentrations at Station 16 were typically as great as $0.2 \mu \mathrm{g} / \mathrm{g}$ (Schmitt and others, 1999b). Concentrations of $0.11-0.19 \mu \mathrm{g} / \mathrm{g}$ were detected in fillet samples of several species obtained from the AC and Llano Grande Lake during the 1980s [unpublished TDH data summarized by Mora (2001)]. Dieldrin concentrations in sediment cores representing 1989-2001 from Llano Grande Lake were generally low (Mahler and Van Metre, 2002), and residues were detected in SPMDs from only the two lowermost (of six) transboundary RG sites sampled by Moring (1999) in July-August 1997. Traces of dieldrin (ca. $0.01 \mu \mathrm{g} / \mathrm{g}$ ) were detected in only three 1992-96 samples collected from the transboundary portions of the RG by the Binational Study (TNRCC, 1994b; 1997), and none was detected by Davis and others (1995). Neither was dieldrin detected in fish or sediment samples collected in 1992-93 from the upper RGB by NAWQA (Carter and Anderholm, 1997; Levings and others, 1998), or in the RG in New Mexico during the 1980s (Ong and others, 1991). However, dieldrin was detected at concentrations $\leq 0.36 \mu \mathrm{g} / \mathrm{g}\left(75^{\text {th }}\right.$ percentile $\left.=0.006 \mu \mathrm{g} / \mathrm{g}\right)$ in $28.9 \%$ of 232 fish samples analyzed nationally by NAWQA (Wong and others, 2000). Dieldrin was detected in whole channel catfish collected by USEPA (1992b) from the AC in 1987 but not in whole carp or white bass fillets from the RG at El Paso. Concentrations were $<0.01-0.01 \mu \mathrm{g} / \mathrm{g}$ in all carp collected in 2001 from resacas and settling basins along the lower RG by Wainwright and others (2001), but dieldrin was detected in the eggs of fish-eating birds from all sites investigated and the maximum concentration $[0.30 \mu \mathrm{g} / \mathrm{g}$ wet-weight in great egrets (Ardea alba) from Falcon International Reservoir] was comparatively high. Dieldrin was not detected in our samples from Falcon Reservoir, however.

Even the greatest 1997 dieldrin concentrations (about $0.05 \mu \mathrm{g} / \mathrm{g}$ ) are 10- to 100 -fold lower than toxicity thresholds for piscivorous wildlife (Newell and others, 1987; Peakall, 1996) and probably do not represent a significant threat to higher-level consumers or the fish. As cited by Jarvinen and Ankley (1999), whole-body residue concentrations of $0.36-2.13 \mu \mathrm{g} / \mathrm{g}$ were not associated with impaired survival or growth of juvenile rainbow trout (Macek and others, 1970; Shubat and Curtis, 1986), and only at concentrations of 5.65 $\mu \mathrm{g} / \mathrm{g}$ did juvenile rainbow trout experience reduced survival (Shubat and Curtis, 1986). This concentration is at least 10fold greater than even the highest contemporary environmental levels in fish (Schmitt, 2002b; Schmitt and others, 2002c).

\section{Endrin}

Endrin, one of the most toxic organochlorine pesticides to fish (Johnson and Finley, 1980), was historically used on cotton but relatively few other crops. In 1997, concentrations were below the detection limit $(0.01 \mu \mathrm{g} / \mathrm{g})$ in all samples (Table 15). Since 1980, traces $(\geq 0.01 \mu \mathrm{g} / \mathrm{g})$ of endrin have been found at Stations 63, 64, and 65 (Schmitt and others, 1999b). At Station 16, concentrations were $0.02 \mu \mathrm{g} / \mathrm{g}$ in 1980 and $0.03 \mu \mathrm{g} / \mathrm{g} 1984$, however (Schmitt and others, 1999b), reflecting the agricultural intensity in the lower RGB and the past use of endrin. In other years, only trace residues were found at Station 16 (Schmitt and others, 1999b). Historically, endrin concentrations were elevated in fish from the AC (Mora and Wainwright, 1997), and residues were detected in 1987 samples by USEPA (1992b). Concentrations of $0.02-0.04 \mu \mathrm{g} / \mathrm{g}$ were common in fish fillet samples obtained from the AC and Llano Grande Lake during the 1980s [unpublished TDH data summarized by Mora (2001)], but concentrations were uniformly low in sediment cores from Llano Grande Lake (Mahler and Van Metre, 2002). Endrin was also detected $(0.01 \mu \mathrm{g} / \mathrm{g})$ in only one sample collected from the transboundary portion of the RG in 1992-96 by the Binational Study (TNRCC, 1994b; 1997), none was detected by Davis and others (1995), and none was detected in fish or sediments collected during 1992-93 from the upper RGB by NAWQA (Carter and Anderholm, 1997; Levings and others, 1998). Nationally, endrin was detected at low concentrations $(\leq 0.016 \mu \mathrm{g} / \mathrm{g})$ and in only $1.7 \%$ of 232 fish samples analyzed by NAWQA (Wong and others, 2000). In the 1995 study of the MRB, endrin was detected only at one site affected by a point-source (Schmitt and others, 2002c).

\section{Other Organochlorine Pesticides}

\section{Toxaphene}

Following the U.S. ban on DDT use, toxaphene was the most heavily used insecticide in the U.S.; most was applied to cotton (Schmitt and Winger, 1980). Toxaphene use peaked in the late 1970s, and it was subsequently banned. Concentrations in NCBP fish samples reflected use patterns, peaking in the mid-1980s (Schmitt and others, 1999b). Although toxaphene was used mostly on cotton, this pesticide has been transported to remote locations and residues have been detected in fish from the Arctic and the Great Lakes (Muir and others, 1999; Schmitt and others, 1999b). In 1997, toxaphene was detected in only six samples from two stations (16 and 511) in the lower RGB (Fig. 7; Table 15). Concentrations at Station 16 were low $(<0.1 \mu \mathrm{g} / \mathrm{g})$ whereas those in fish from Station $511(0.56-2.40 \mu \mathrm{g} / \mathrm{g})$ were similar to 1995 levels in fish from cotton-growing regions of the lower MRB (Schmitt and others, 2002c). Toxaphene is therefore among the contaminants included in the present consumption advisory for fish from the AC (Station 511) and nearby waters.

Toxaphene concentrations were historically elevated in fish from the lower RGB. Although most 1976-86 samples of whole fish from Station 16 contained only 0.3-1.4 $\mu \mathrm{g} / \mathrm{g}$ (Schmitt and others, 1999b), concentrations $>20 \mu \mathrm{g} / \mathrm{g}$ were typical of fish collected from the AC and Llano Grande Lake in 1978-79 (White and others, 1983). Concentrations were 
also typically 5-10 $\mu \mathrm{g} / \mathrm{g}$ in fillet samples obtained from the AC and Llano Grande Lake during the 1980s [unpublished TDH data summarized by Mora (2001)]. Toxaphene was not detected in any samples collected from the transboundary portion of the RG in 1992-96 by the Binational Study (TNRCC, 1994b; 1997), by Davis and others (1995), in fish from the upper RGB collected in 1992-93 by NAWQA (Carter and Anderholm, 1997; Levings and others, 1998), or in the RG in New Mexico during the 1980s (Ong and others, 1991). Toxaphene concentrations were also uniformly low in sediment cores from Llano Grande Lake (Mahler and Van Metre, 2002). In contrast, concentrations were as great as $0.3 \mu \mathrm{g} / \mathrm{g}$ in carp collected from resacas and settling basins along the lower RG by Wainwright and others (2001). In addition, greenback heron eggs from sites along the lower RG contained as much as $4.4 \mu \mathrm{g} / \mathrm{g}$, the greatest concentration ever reported in bird eggs from this region (Wainwright and others, 2001). Nationally, toxaphene was detected in only $0.4 \%$ of the 233 samples analyzed by NAWQA at concentrations $\leq 0.4 \mu \mathrm{g} / \mathrm{g}$ (Wong and others, 2000), a level exceeded by all 1997 samples from Station 511. The samples collected in 1987 from the RG at El Paso and the AC at Harlingen as part of the National Study of Chemical Residues in Fish were not analyzed for toxaphene (USEPA, 1992a). Toxaphene concentrations in fish from Stations 63,64 , and 65 collected in 1980-86 by the NCBP were, with one exception, $\leq 0.1 \mu \mathrm{g} / \mathrm{g}$. In contrast, concentrations at Station 16 were historically 0.2-1.0 $\mu \mathrm{g} / \mathrm{g}$ (Schmitt and others, $1999 b)$. It should also be noted that methodological inconsistencies confound comparisons among studies.

Acute and chronic effects on freshwater fish have been noted at whole-body toxaphene concentrations $\geq 0.4 \mu \mathrm{g} / \mathrm{g}$ (Eisler and Jacknow, 1985; Jarvinen and Ankley 1999), a level exceeded by all samples from Station 511. Jarvinen and Ankley (1999) cited a number of laboratory studies on the acute and chronic effects of toxaphene. Among these were several by Mayer and others $(1978 ; 1975)$, who reported that adult brook trout containing whole-body concentrations of $0.4 \mu \mathrm{g} / \mathrm{g}$ produced eggs with reduced viability, and lake trout (Salvelinus namaycush) and white suckers containing 0.035$0.203 \mu \mathrm{g} / \mathrm{g}$ also produced eggs with reduced viability. Survival and growth of freshwater fish (several species) at various life stages were reduced at concentrations $>0.90 \mu \mathrm{g} / \mathrm{g}$ (Mayer and others, 1975; 1978). It should be noted that the composition and potential toxicity of weathered toxaphene can vary greatly (Bidleman and others, 1993; Gooch and Matsamura, 1987; Harder and others, 1983; Ribick and others, 1982), and that composition of the residues present in the 1997 samples can't be determined from the low-resolution methods used (Ribick and others, 1982). In addition, the concentrations reported here should be considered estimates due to the low resolution of the analytical methods employed (Schmitt, 2002b).

\section{Mirex}

In the southern United States, mirex was used as an insecticide to combat red imported fire ants (Solenopsis wagneri). Elsewhere, mirex was used as a flame retardant and as a polymerizing agent (Kaiser, 1987). Consistent with previous NCBP findings (Schmitt and others, 1999b), mirex was not detected $(<0.01 \mu \mathrm{g} / \mathrm{g})$ in any 1997 samples from the RGB (Table 15). Other recent studies have also failed to detect mirex in fish from the RGB (Carter and Anderholm, 1997; Davis and others, 1995; Levings and others, 1998; Ong and others, 1991; TNRCC, 1994b; 1997), and none was detected in any of the 233 fish samples analyzed nationally by NAWQA (Wong and others, 2000). Mirex was also not detected in any 1987 samples from either the RG at El Paso or the AC at Harlingen (USEPA, 1992b). In the 1995 study of the MRB (Schmitt and others, 2002c), traces of mirex were detected in a few samples from Louisiana, however.

\section{Hexachlorocyclohexanes $(\mathrm{HCH})$}

Four $\mathrm{HCH}$ isomers $(\alpha, \beta, \delta$, and $\gamma)$ were measured in the 1997 samples. Although mixtures of $\mathrm{HCH}$ isomers were historically used on cotton and other crops in the U.S., by 1997 only $\gamma-\mathrm{HCH}$ (lindane) remained in use in North America for some agricultural and domestic applications ( $\mathrm{Li}$ and others, 1996; Poissant and Koprivnjak, 1996). HCH isomers are relatively volatile and are rapidly cleared by fish (Butte and others, 1991; Willett and others, 1998). Concentrations of all isomers in all 1997 samples were below the LOD $(0.01 \mu \mathrm{g} / \mathrm{g})$ in 1997 (Table 15). In samples collected from the four NCBP sites in the RGB from 1978-1986, $\alpha$ - and $\gamma$-HCH concentrations did not exceed $0.02 \mu \mathrm{g} / \mathrm{g}$, and all 1986 samples contained $<0.005 \mu \mathrm{g} / \mathrm{g}$ (Schmitt and others, 1999b). Other studies in the RGB have also reported only low or non-detected concentrations of $\mathrm{HCH}$ isomers. None were detected in the RG in New Mexico during the 1980s (Ong and others, 1991). Whole carp and white bass (fillets) collected in 1987 from the RG at El Paso and whole channel catfish from the AC contained only traces of $\alpha$ - and $\gamma-\mathrm{HCH}$ (USEPA, 1992b), and traces of $\gamma-\mathrm{HCH}$ were detected in $9 \%$ of the fish sampled from the upper RGB in 1992-93 by NAWQA (Carter and Anderholm, 1997; Levings and others, 1998). No HCH isomers were detected in any 1992-96 fish samples from the transboundary RG collected by the Binational Study (TNRCC, 1994b; 1997), but traces were present in two of 94 samples analyzed by Davis and others (1995). Nationally, $\alpha$ - and $\gamma-\mathrm{HCH}$ were both detected at low concentrations $(\leq 0.055 \mu \mathrm{g} / \mathrm{g})$ in $0.4 \%$ of the fish samples analyzed by NAWQA, but $\beta-\mathrm{HCH}$ was not detected $(<0.005 \mu \mathrm{g} / \mathrm{g})$ (Wong and others, 2000). 


\section{Hexachlorobenzene (HCB)}

Hexachlorobenzene was used as a fungicide; it is also a by-product of the production of other chlorinated hydrocarbons. HCB is less toxic to fish than many other persistent organochlorines (Schmitt and others, 1999b), but may contain toxic impurities, including TCDD. Concentrations of HCB were universally below the detection limit (that is, $<0.01$ $\mu \mathrm{g} / \mathrm{g}$ ) in all 1997 samples (Table 15), which is consistent with NCBP findings since 1978 (Schmitt and others, 1999b). Other investigations have also reported only low HCB concentrations in fish. Whole carp and white bass collected from the RG at El Paso in 1987 contained traces $(<0.01 \mu \mathrm{g} / \mathrm{g})$ of HCB, but none was detected in whole channel catfish from the $\mathrm{AC}$ at Harlingen (USEPA, 1992b). No HCB was detected in fish collected during 1992-96 from the transboundary portions of the RG by the Binational Study (TNRCC, 1994b; 1997) or by Davis and others (1995), but traces were present in $9 \%$ of the fish samples obtained in 1992-93 from the upper RGB by NAWQA (Carter and Anderholm, 1997; Levings and others, 1998). None was detected in the RG in New Mexico by Ong and others (1991). Nationally, HCB was detected at low concentrations $(\leq 0.033 \mu \mathrm{g} / \mathrm{g})$ in $7.3 \%$ of 234 fish samples analyzed by NAWQA (Wong and others, 2000).

\section{Organochlorine Pesticides not Measured}

The low-resolution organochlorine scan used to analyze the 1997 samples from the RGB was selected to yield quality data for a broad spectrum of compounds at a reasonable cost. This approach was justified because concentrations of these compounds, most of which are no longer used in the U.S., were expected to be low. Results of the 1997 analyses, as well as those of the other studies cited, proved this assumption to be true, and resources not devoted to the analysis of organochlorine chemicals were available for other aspects of the study. Several compounds of potential importance in the RGB were not accounted for, however. Among these was Dacthal ${ }^{\circledR}$, an organochlorine herbicide that is used heavily to control weeds in ornamental, turf, and vegetable crops. Dacthal ${ }^{\circledR}$ was detected in SPMD samples from five of the six sites sampled in July-August 1997 by Moring (1999). In 1986, Dacthal ${ }^{\circledR}$ concentrations in fish from Station 16 averaged $0.14 \mu \mathrm{g} / \mathrm{g}$, which was the highest nationally (Schmitt and others, 1999b), and in 1984 a concentration of $0.45 \mu \mathrm{g} / \mathrm{g}$ was reported in an individual sample (Schmitt and others, 1990). The occurrence of this compound was increasing nationally through the 1980s (Schmitt and others, 1999b), but concentrations in fish were not measured by any of the other recent investigations of the lower RGB (USEPA, 1992a; TNRCC, 1994b; 1997) and none was detected in the upper RGB by NAWQA (Carter and Anderholm, 1997; Levings and others, 1998) or in the RG in New Mexico by Ong and others (1991). In contrast, residues were detected regularly in fish samples (fillets) collected during the 1980s from many sites in the lower RGB [unpublished
TDH data summarized by Mora (2001)]. Nationally, Dacthal ${ }^{\circledR}$ was detected at low concentrations $(\leq 0.067 \mu \mathrm{g} / \mathrm{g})$ in $3 \%$ of 231 fish samples analyzed by NAWQA (Wong and others, 2000). Dacthal ${ }^{\circledR}$ was also detected $(0.003-0.03 \mu \mathrm{g} / \mathrm{L})$ in NASQAN water samples from Stations 512 (RG at Brownsville) and 516 (RG at El Paso) during 1995-97.

NCBP samples collected in 1986 from Stations 16, 63, 64 , and 65 were also analyzed for residues of pentachloroanisole (PCA), a metabolite of the wood preservative pentachlorophenol; concentrations were below the LOD $(<0.005$ $\mu \mathrm{g} / \mathrm{g}$ ) in all samples (Schmitt and others, 1999b). However, carp (whole and fillet) collected from the RG at El Paso in 1987 contained $<0.003 \mu \mathrm{g} / \mathrm{g}$, and channel catfish from the AC at Harlingen contained traces $(0.006 \mu \mathrm{g} / \mathrm{g})$ (USEPA, 1992b). PCA was not reported for the upper RG by NAWQA (Carter and Anderholm, 1997; Levings and others, 1998), or in the middle RG by Ong and others (1991) but it was detected at low concentrations $(\leq 0.087 \mu \mathrm{g} / \mathrm{g})$ in $8.2 \%$ of 232 fish samples analyzed nationally by NAWQA (Wong and others, 2000). Residues of PCA were also detected in SPMD samples from two of the six sites sampled in July-August 1997 (below Laredo and below Brownsville) by Moring (1999).

Endosulfan is among the few organochlorine insecticides currently registered for use in the U.S.; more than $38,000 \mathrm{~kg} / \mathrm{y}$ was used in Texas from 1990-93 (Mora and Wainwright, 1997, citing other sources). Neither endosulfan nor its metabolites were measured by the NCBP or by USEPA (1992a). Endosulfan and its metabolites were measured in samples from the upper RG by NAWQA (Carter and Anderholm, 1997; Levings and others, 1998) and from transboundary reaches of the RG by the Binational Study (TNRCC, 1994b; 1997), but all concentrations were below detection limits. Conversely, Davis and others (1995) detected traces of endosulfan sulfate in one sample collected in 1994. Endosulfan was not among the compounds characterized nationally in surficial streambed sediments and biota by NAWQA (Wong and others, 2000) nor was it measured by Ong and others (1991).

\section{Total PCBs, H4IIE-Derived Dioxin Equivalents, and Ethoxyresorufin 0-Deethylase (EROD) Activity}

\section{Total PCBs}

Total PCB concentrations were less than the LOD (0.05 $\mu \mathrm{g} / \mathrm{g}$ ) in all 1997 samples (Table 15), which confirms the findings of previous RGB investigations reporting only low PCB concentrations in fish. With only one exception, NCBP samples from Stations 16, 63, 64, and 65 have contained $\leq 0.1$ $\mu \mathrm{g} / \mathrm{g}$ of PCBs (as Aroclors ${ }^{\circledR}$ 1248, 1254, and 1260) since 1980 (Schmitt and others, 1999b). Samples of whole carp and white bass from the RG at El Paso and whole channel catfish from the AC at Harlingen obtained by USEPA in 1987 also 
contained relatively low concentrations $(0.09-0.24 \mu \mathrm{g} / \mathrm{g})$ of total PCBs (USEPA, 1992b). Similarly, PCB residues were detected $(0.1-1.0 \mu \mathrm{g} / \mathrm{g})$ in only $45 \%$ of the fish collected in 1992-93 from the upper RGB by NAWQA (Carter and Anderholm, 1997; Levings and others, 1998) and in only a few samples obtained from the RG in New Mexico during the 1980s (Ong and others, 1991). Concentrations of 0.10$0.28 \mu \mathrm{g} / \mathrm{g}$ were detected in fish from several lower RG sites sampled by the Binational Study (TNRCC, 1994b; 1997), and Davis and others (1995) reported total PCB concentrations of $0.48-0.58 \mu \mathrm{g} / \mathrm{g}$ in two species of fish obtained in 1994 from a site near Brownsville. Total PCB concentrations in sediment cores from Llano Grande Lake were uniformly low (Mahler and Van Metre, 2002). The maximum concentration in carp collected from lower RGB resacas and settling basins in 1997 by Wainwright and others (2001) was $0.22 \mu \mathrm{g} / \mathrm{g}$; however, great egret eggs from Falcon International Reservoir contained as much as $1.50 \mu \mathrm{g} / \mathrm{g}$. In contrast to most other studies, fillet samples of several fish species obtained in 1993 by TDH from Donna Reservoir, in the lower RGB, contained as much as 9.6 $\mu \mathrm{g} / \mathrm{g}$ of PCBs [unpublished data summarized by Mora (2001)], and concentrations in carp and smallmouth buffalo (Ictiobus bubalus) fillets from Donna Reservoir were as great as 24.0 $\mu \mathrm{g} / \mathrm{g}$ in 1993 (Wainwright and others, 2001). These findings indicate that there is some localized PCB contamination in the lower RGB. Nevertheless, the overall 1997 PCB concentrations in fish from the RGB were lower than most reported for the MRB in 1995 (Schmitt and others, 2002c), as was the range of values reported by other recent RGB investigations. They are also low relative to those reported nationally by NAWQA $\left(75^{\text {th }}\right.$ percentile $=0.15 \mu \mathrm{g} / \mathrm{g}$, maximum $\left.=7.2 \mu \mathrm{g} / \mathrm{g}\right)$ (Wong and others, 2000).

\section{H4IIE Bioassay}

The H4IIE bioassay detected relatively low dioxin-like activity ( $\leq 6 \mathrm{pg} / \mathrm{g}$ ) in all 1997 samples from the RGB (Fig. 9; Table 16), indicating minimal contamination by PHH. Only three samples contained $\geq 4 \mathrm{pg} / \mathrm{g}$, all from Stations 511 and 512 (Fig. 9). TCDD-EQ in female carp $(n=12)$ ranged from $<\mathrm{LOD}(<0.35 \mathrm{pg} / \mathrm{g}$; four samples) to $3 \mathrm{pg} / \mathrm{g}$, whereas male carp $(n=11)$ ranged from $<0.71$ to $3 \mathrm{pg} / \mathrm{g}$ with one sample below the LOQ. TCDD-EQs were $<0.94-4 \mathrm{pg} / \mathrm{g}$ in female bass $(n=6)$ with one value below the LOQ whereas in male bass $(n=6)$ all values were $1-6 \mathrm{pg} / \mathrm{g}$. In the other 11 samples, which comprised channel catfish, Morone sp., and northern pike, TCDD-EQs were also relatively low $(<0.4-5 \mathrm{pg} / \mathrm{g})$. Most 1997 TCDD-EQ levels in fish from the RGB were similar to those reported for reference sites in previous studies (Giesy and others, 1995; Schmitt and others, 2002c; van den Heuvel and others, 1996; Whyte and others, 2004). Whole carp and white bass (fillets) obtained in 1987 from the RG at El Paso by USEPA contained 0.03-0.06 pg/g TCDD-EQ (determined by analytical methods), and whole channel catfish from the AC at Harlingen contained $2.19 \mathrm{pg} / \mathrm{g}$, the latter about the $30^{\text {th }}$ percen-

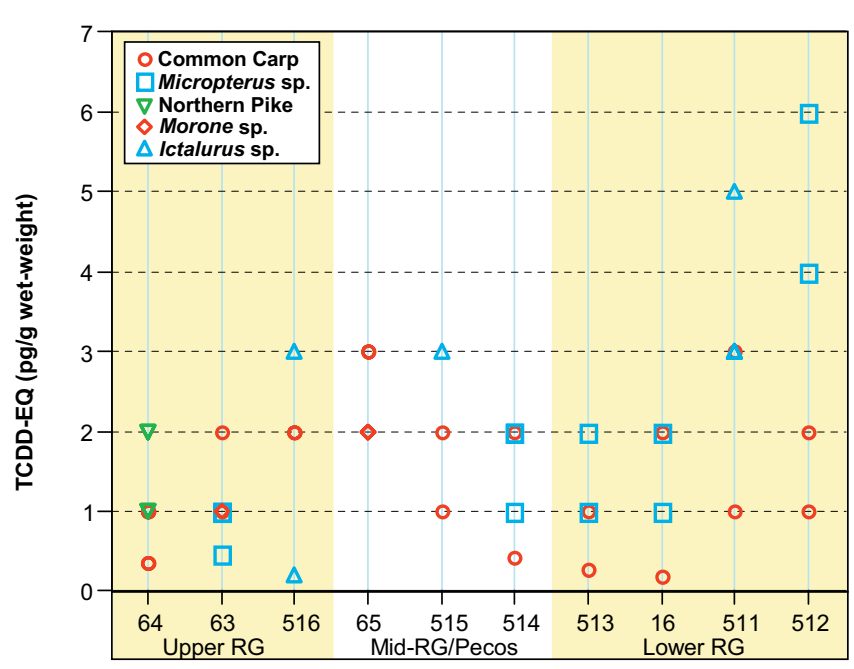

Station

Figure 9. Concentrations of H4IIE bioassay-derived TCDD-EO in composite samples of whole fish, by station and taxon. Stations are ordered from upstream to downstream and are grouped by sub-basin. See Table 1 for station descriptions and collection dates. Micropterus sp., largemouth or smallmouth bass; Morone $\mathrm{sp} .$, white bass or striped bass; Ictalurus sp., blue or channel catfish.

tile nationally (USEPA, 1992b). Elsewhere USEPA reported concentrations as great as 100-400 pg/g from heavily contaminated sites(Kuehl and others, 1994; USEPA, 1992a). Some TCDD-EQ values were $\geq 60 \mathrm{pg} / \mathrm{g}$ and levels $\geq 20 \mathrm{pg} / \mathrm{g}$ were widespread in fish collected from the MRB in 1995 (Schmitt and others, 2002c).

The dietary threshold for TCDD-EQ toxicity in mammals is $4.4 \mathrm{pg} / \mathrm{g}$ (Heaton and others, 1995; Tillitt and others, 1996) and for avian wildlife it is about $5 \mathrm{pg} / \mathrm{g}$ (Nosek and others, 1992). One sample from each of Stations 511 and 512 exceeded both values (Fig. 9). No 1997 samples from the RGB approached the threshold for toxic effects in fish, which is about $35 \mathrm{pg} / \mathrm{g}$ (see Schmitt and others, 2002c and references cited therein; Whyte and others, 2004). The universally low levels of TCDD-EQ in RGB fish samples are consistent with the lack of detectable PCB residues. These findings are also consistent with earlier reports indicating only low levels of contamination by chlorinated dioxins and PCBs in the lower RGB (USEPA, 1992b).

\section{Ethoxyresorufin 0-Deethylase (EROD) Activity}

EROD activity varies among fish species, between genders, and with gonadal stage (Schmitt and others, 2002c; Whyte and others, 2000). In RGB carp, a statistically significant ANOVA model containing the factors station, gender, and gonadal stage explained $56 \%$ of the total variance in log-transformed EROD activity, but no individual factors or interactions 
were significant (Table 17); that is, after accounting for all other factors in the model, differences among stations were not significant. In bass, the ANOVA model was also significant and explained 57\% of the total variance; however, in contrast to carp, EROD activity in bass differed significantly among stations after accounting for all other effects. In addition, the interaction of station and sex was also significant (Table 17). Analysis of the larger 1995 data set from the MRB, which spanned a wider range of EROD values, also indicated that gender was significant for carp (Schmitt and others, 2002c). For all of these reasons, EROD activity was tabulated and evaluated by gonadal stage in both carp and bass (Appendix Table 4).

\section{EROD in carp}

In female carp, EROD activity was greatest at Stations 511 and 512; geometric station means (stages combined) were 16.8 and $9.44 \mathrm{pmol} / \mathrm{min} / \mathrm{mg}$, respectively (Fig. 10; Table 18). Mean EROD activity in four stage-0 female carp from Station 511 was $61.0 \mathrm{pmol} / \mathrm{min} / \mathrm{mg}$, ranging from 18.2 to $161.1 \mathrm{pmol} /$ $\mathrm{min} / \mathrm{mg}$; the latter was the greatest value measured (Appendix Table 4). EROD activity in stage-1 and -2 female carp was $0-84.0 \mathrm{pmol} / \mathrm{min} / \mathrm{mg}$, with a basin-wide mean of $5.0 \mathrm{pmol} /$ $\mathrm{min} / \mathrm{mg}$ (Appendix Table 4). The greatest station means for stage- 1 and -2 female carp were for Stations 511 and 512; all others were much lower (Appendix Table 4). At Stations 511 and 512 , most EROD values were $>10.0 \mathrm{pmol} / \mathrm{min} / \mathrm{mg}$, and the rate in one stage- 2 female carp from Station 65 was 55.5 $\mathrm{pmol} / \mathrm{min} / \mathrm{mg}$ (Fig. 10; Appendix Table 4). Individual values of $5-10 \mathrm{pmol} / \mathrm{min} / \mathrm{mg}$ were also recorded in other female carp from Station 65 and in several from Station 513 (Fig. 10). EROD rates in most (84\%) stage-1 and -2 female carp were $0-5 \mathrm{pmol} / \mathrm{min} / \mathrm{mg}$, about the same as the $0-4 \mathrm{pmol} / \mathrm{min} / \mathrm{mg}$ range identified as "normal" expression for female carp from uncontaminated sites in previous studies (Schlenk and others, 1996a; Schlenk and others, 1996b; Schmitt and others, 2002c; Whyte and others, 2000). Nevertheless, EROD rates in at least one fish from all sites exceeded $4 \mathrm{pmol} / \mathrm{min} / \mathrm{mg}$, and the one elevated value at Station 65 and most from Station 511 and 512 were $>10 \mathrm{pmol} / \mathrm{min} / \mathrm{mg}$, indicating that these fish had been exposed to exogenous Ah-R agonists. EROD activity was as great or greater in many female carp from Station 511 (Fig. 10) as it was in those from the most contaminated MRB sites sampled in 1995 (Schmitt and others, 2002c).

EROD activity in male carp was similar to, and generally paralleled, activity in female carp (Fig. 10; Table 18). Only one stage-1 male (from Station 16) was analyzed; it had a low EROD rate $(4.0 \mathrm{pmol} / \mathrm{min} / \mathrm{mg})$, and one carp of unknown gender or stage (no gonad was preserved) from Station 64 was $<0.01 \mathrm{pmol} / \mathrm{min} / \mathrm{mg}$ (Appendix Table 4). EROD activity in stage- 2 and -3 male carp ranged from $<0.01$ to $54.2 \mathrm{pmol} / \mathrm{min} /$ $\mathrm{mg}$ with a basin-wide mean of $7.8 \mathrm{pmol} / \mathrm{min} / \mathrm{mg}$ (Appendix Table 4). Station means for stages 2 and 3 ranged from 1.1 $\mathrm{pmol} / \mathrm{min} / \mathrm{mg}$ at Station 64 to $34.6 \mathrm{pmol} / \mathrm{min} / \mathrm{mg}$ at Station
511. Stage- 2 and -3 means were also $>10.0 \mathrm{pmol} / \mathrm{min} / \mathrm{mg}$ at Stations 63 (11.7 pmol/min/mg), 512 (10.1 pmol $/ \mathrm{min} / \mathrm{mg})$, and $516(11.3 \mathrm{pmol} / \mathrm{min} / \mathrm{mg})$. EROD activity in most male carp (72\%) was $<0.01-8.0 \mathrm{pmol} / \mathrm{min} / \mathrm{mg}$ (Fig. 10; Table 18). The upper part of this range is slightly greater than the $0-6 \mathrm{pmol} / \mathrm{min} / \mathrm{mg}$ identified as indicative of un-induced or reference conditions in previous studies (Schlenk and others, 1996a; Schlenk and others, 1996b; Schmitt and others, 2002c; Whyte and others, 2000). Slightly elevated EROD rates ( $>8.0$ $\mathrm{pmol} / \mathrm{min} / \mathrm{mg}$ ) were detected in individual male carp from Stations 63, 511, 512, 514, and 516 (Fig. 10). In addition, and as described for female carp, EROD rates in male carp from Station 511 were as great as those in male carp from the most contaminated MRB sites sampled in 1995 by Schmitt and others (2002c), indicating substantial exposure of the fish to exogenous Ah-R agonists at this site.

\section{EROD in bass}

As is typical for these fishes (Schmitt and others, 2002c; Whyte and others, 2000), EROD rates were greater in bass than in carp (Fig. 10; Table 18). EROD activity in stage-1 female bass ranged from 5.0 to $107.4 \mathrm{pmol} / \mathrm{min} / \mathrm{mg}$ (Appendix Table 4), with a basin-wide mean of $46.3 \mathrm{pmol} / \mathrm{min} / \mathrm{mg}$. EROD rates in $95 \%$ of stage- 1 female bass exceeded 15.0 $\mathrm{pmol} / \mathrm{min} / \mathrm{mg}$, and $75 \%$ were $>30.0 \mathrm{pmol} / \mathrm{min} / \mathrm{mg}$. Station means for stage- 1 female bass ranged from $18.0 \mathrm{pmol} / \mathrm{min} / \mathrm{mg}$ at Station 514 to $77.1 \mathrm{pmol} / \mathrm{min} / \mathrm{mg}$ at Station 512 (Appendix Table 4). The minimum value at all stations except Station 514 was $>15.0 \mathrm{pmol} / \mathrm{min} / \mathrm{mg}$, and all values in fish from Stations 63 and 512 exceeded $25.0 \mathrm{pmol} / \mathrm{min} / \mathrm{mg}$ (Fig. 10). Although EROD activity in stage- 2 female bass was generally less than in stage- 1 females, the ranges were similar (Appendix Table 4). Elevated EROD rates were also detected in stage-0 female bass from Station 512 (55.1 and 67.5 $\mathrm{pmol} / \mathrm{min} / \mathrm{mg}$ ) and in stage-3 females from Station 63 (79.6 and $147.2 \mathrm{pmol} / \mathrm{min} / \mathrm{mg}$ ), both of which are similar to stage-1 activity at these stations (Appendix Table 4). EROD rates in two stage-4 female bass from Station 514 were slightly greater ( 38.1 and $44.3 \mathrm{pmol} / \mathrm{min} / \mathrm{mg}$ ) than those of stage- 1 females from this site (Fig. 10; Appendix Table 4). Most EROD values in female bass exceeded the $16 \mathrm{pmol} / \mathrm{min} / \mathrm{mg}$ threshold for basal activity established in other studies (Adams and others, 1994; Schlenk and others, 1996a; Schlenk and others, 1996b; Schmitt and others, 2002c; Whyte and others, 2000). In addition, EROD rates in several female bass from Station 513 and 512 and in most from Station 63 were about the same as those from some of the most contaminated MRB sites sampled in 1995 by Schmitt and others (2002c). Collectively, these data indicate that female bass were exposed to exogenous Ah- $R$ ligands at all RGB sites from which they were obtained.

EROD rates in male bass were also greater than for male carp (Fig. 10; Table 18), and some exceeded the reference threshold for basal activity ( $22 \mathrm{pmol} / \mathrm{min} / \mathrm{mg}$ ) established by other studies (Adams and others, 1994; Schlenk and others, 
Table 17. Results of preliminary analysis-of-variance investigating the effects of various factors on biomarker ${ }^{a}$ responses in carp and bass (Micropterus sp.) from the Rio Grande Basin. Shown are degrees-of-freedom (df), $F$-values with significance levels $\left({ }^{*} 0.01<P \leq 0.05 ;{ }^{* *} P \leq 0.01\right)$, and coefficients of determination $\left(R^{2}\right)$.-

\begin{tabular}{|c|c|c|c|c|c|c|}
\hline \multirow{2}{*}{$\begin{array}{l}\text { Variable, source, and } \\
\text { (transformation) }\end{array}$} & \multicolumn{3}{|c|}{ Carp } & \multicolumn{3}{|c|}{ Bass } \\
\hline & $\mathrm{df}$ & $F$ & $R^{2}$ & $d f$ & $F$ & $R^{2}$ \\
\hline \multicolumn{7}{|l|}{ EROD $(\log )$} \\
\hline Model & 28 & $7.53 * *$ & 0.56 & 15 & $4.91 * *$ & 0.57 \\
\hline Station & 6 & 1.08 & -- & 4 & $3.78 * *$ & -- \\
\hline Sex & 1 & 0.27 & -- & 1 & 2.23 & -- \\
\hline Station*Sex & 1 & 0.06 & -- & 1 & 0.19 & -- \\
\hline Stage & 1 & 0.65 & -- & 1 & 2.05 & -- \\
\hline Stage*Station & 6 & 0.57 & -- & 4 & 2.15 & -- \\
\hline Stage*Sex & 1 & $<0.01$ & -- & 1 & $4.38^{*}$ & -- \\
\hline Stage*Station*Sex & 1 & 0.27 & -- & 1 & $<0.01$ & -- \\
\hline Error & 163 & -- & -- & 56 & -- & -- \\
\hline \multicolumn{7}{|l|}{ HAI (rank) } \\
\hline Model & 28 & $2.47 * *$ & 0.28 & 15 & $2.62 * *$ & 0.41 \\
\hline Station & 6 & 0.92 & -- & 4 & $2.01(P=0.11)$ & \\
\hline Sex & 1 & 0.18 & -- & 1 & 0.6 & -- \\
\hline Station*Sex & 1 & $2.13(P=0.15)$ & & 1 & $4.91 *$ & -- \\
\hline Stage & 1 & $6.65 * *$ & -- & 1 & 0.01 & -- \\
\hline Stage*Station & 6 & 0.87 & -- & 4 & 1.49 & -- \\
\hline Stage*Sex & 1 & 0.09 & -- & 1 & $2.02(P=0.16)$ & \\
\hline Stage*Station*Sex & 1 & $2.04(P=0.15)$ & & 1 & $8.61 * *$ & -- \\
\hline Error & 176 & -- & -- & 56 & -- & -- \\
\hline \multicolumn{7}{|l|}{$\mathrm{CF}$} \\
\hline Model & 28 & 0.67 & 0.09 & 15 & $12.94 * *$ & 0.78 \\
\hline Station & 1 & $<0.01$ & -- & 4 & $10.67^{* *}$ & -- \\
\hline Sex & 1 & $<0.01$ & -- & 1 & $40.74^{* *}$ & -- \\
\hline Station*Sex & 1 & $<0.01$ & -- & 1 & $51.20^{* *}$ & -- \\
\hline Stage & 1 & $<0.01$ & -- & 1 & $58.29^{* *}$ & -- \\
\hline Stage*Station & 6 & $<0.01$ & -- & 4 & $12.39^{* *}$ & -- \\
\hline Stage*Sex & 1 & $<0.01$ & -- & 1 & $40.74 * *$ & -- \\
\hline Stage*Station*Sex & 1 & $<0.01$ & -- & 1 & $56.17^{* *}$ & -- \\
\hline Error & 176 & -- & -- & 56 & -- & -- \\
\hline \multicolumn{7}{|l|}{ HSI } \\
\hline Model & ND & ND & ND & 7 & 1.1 & 0.12 \\
\hline Station & ND & ND & -- & 3 & 1.9 & -- \\
\hline Sex & ND & ND & -- & 1 & 0.92 & -- \\
\hline Station*Sex & ND & ND & -- & 3 & 0.35 & -- \\
\hline Error & ND & -- & -- & 57 & -- & -- \\
\hline \multicolumn{7}{|l|}{ SSI } \\
\hline Model & 19 & $4.35^{* *}$ & 0.31 & 8 & $1.92(P=0.07)$ & 0.19 \\
\hline Station & 9 & $6.26^{* *}$ & -- & 4 & $2.63 *$ & -- \\
\hline Sex & 1 & $11.81^{* *}$ & -- & 1 & 1.37 & -- \\
\hline Station*Sex & 9 & 1.21 & -- & 3 & 0.65 & -- \\
\hline Error & 183 & -- & -- & 63 & -- & -- \\
\hline \multicolumn{7}{|l|}{ MAMM } \\
\hline Model & 38 & $3.94 * *$ & 0.52 & 17 & $2.03^{*}$ & 0.39 \\
\hline Station & 9 & $4.75^{* *}$ & -- & 4 & $2.09(P=0.10)$ & -- \\
\hline Sex & 1 & $2.00(P=0.15)$ & -- & 1 & 0.24 & -- \\
\hline
\end{tabular}


Table 17. Results of preliminary analysis-of-variance investigating the effects of various factors on biomarker ${ }^{a}$ responses in carp and bass (Micropterus sp.) from the Rio Grande Basin. Shown are degrees-of-freedom (df), $F$-values with significance levels $\left({ }^{*} 0.01<P \leq 0.05 ;{ }^{* *} P \leq 0.01\right)$, and coefficients of determination $\left(R^{2}\right)$.-Continued

\begin{tabular}{|c|c|c|c|c|c|c|}
\hline \multirow{2}{*}{$\begin{array}{l}\text { Variable, source, and } \\
\text { (transformation) }\end{array}$} & \multicolumn{3}{|c|}{ Carp } & \multicolumn{3}{|c|}{ Bass } \\
\hline & df & $F$ & $R^{2}$ & $d f$ & $F$ & $R^{2}$ \\
\hline Station*Sex & 8 & $1.69(P=0.11)$ & -- & 3 & 0.3 & -- \\
\hline Age & 1 & 0.12 & -- & 1 & 0.4 & -- \\
\hline Age*Station & 9 & 1.3 & -- & 4 & $1.83(P=0.14)$ & -- \\
\hline Age*Sex & 1 & 0.42 & -- & 1 & 0.84 & -- \\
\hline Age*Station*Sex & 8 & $1.48(P=0.16)$ & & 3 & 0.6 & -- \\
\hline Error & 136 & -- & -- & 53 & -- & -- \\
\hline \multicolumn{7}{|l|}{ MEANAREA (log) } \\
\hline Model & 38 & $4.86^{* *}$ & 0.57 & 17 & $1.96^{*}$ & 0.39 \\
\hline Station & 9 & $5.56^{* *}$ & -- & 4 & $1.93(P=0.11)$ & -- \\
\hline Sex & 1 & 1.72 & -- & 1 & 0.43 & -- \\
\hline Station*Sex & 8 & 1.26 & -- & 3 & 0.52 & -- \\
\hline Age & 1 & 1.14 & -- & 1 & 0.25 & -- \\
\hline Age*Station & 9 & 0.91 & -- & 4 & $2.11(P=0.09)$ & -- \\
\hline Age*Sex & 1 & 0.49 & -- & 1 & 1.00 & -- \\
\hline Age*Station*Sex & 8 & 1.19 & -- & 3 & 0.51 & -- \\
\hline Error & 137 & -- & -- & 53 & -- & -- \\
\hline \multicolumn{7}{|l|}{ TISSOC (log) } \\
\hline Model & 38 & $5.61 * *$ & 0.61 & 17 & $2.10 *$ & 0.40 \\
\hline Station & 9 & $6.62 * *$ & -- & 4 & 1.27 & -- \\
\hline Sex & 1 & 1.71 & -- & 1 & $<0.01$ & -- \\
\hline Station*Sex & 8 & 0.72 & -- & 3 & 1.08 & -- \\
\hline Age & 1 & $2.91(P=0.09)$ & -- & 1 & 2.60 & -- \\
\hline Age*Station & 9 & 1.06 & -- & 4 & 1.74 & -- \\
\hline Age*Sex & 1 & 1.91 & -- & 1 & 0.10 & -- \\
\hline Age*Station*Sex & 8 & 1.01 & -- & 3 & 0.86 & -- \\
\hline Error & 137 & -- & -- & 53 & -- & -- \\
\hline \multicolumn{7}{|l|}{ Atresia $^{b}$} \\
\hline Model & 25 & $2.69 * *$ & 0.49 & 17 & $25.41^{* *}$ & 0.95 \\
\hline Station & 1 & 0.04 & -- & 3 & 0.13 & -- \\
\hline Stage & 1 & 0.73 & -- & 1 & 0.46 & -- \\
\hline Stage*Station & 1 & 0.93 & -- & 3 & 0.52 & -- \\
\hline Age & 1 & $1.55(P=0.11)$ & -- & 1 & 0.02 & -- \\
\hline Age*Station & 1 & 0.19 & -- & 3 & $2.04(P=0.13)$ & -- \\
\hline Stage*Age & 1 & 1.29 & -- & 1 & $<0.01$ & -- \\
\hline Stage*Age*Station & 1 & 0.15 & -- & 3 & $5.01 * *$ & -- \\
\hline Error & 71 & -- & -- & 23 & -- & -- \\
\hline \multicolumn{7}{|l|}{ GSI } \\
\hline Model & 28 & $16.26^{* *}$ & 0.72 & 15 & $8.73 * *$ & 0.70 \\
\hline Station & 6 & $4.58 * *$ & -- & 4 & $2.42(P=0.06)$ & -- \\
\hline Sex & 1 & 0.19 & -- & 1 & $7.85^{* *}$ & -- \\
\hline Station*Sex & 1 & 0.1 & -- & 1 & $3.88^{*}$ & -- \\
\hline Stage & 1 & $11.41 * *$ & -- & 1 & $18.44 * *$ & -- \\
\hline Stage*Station & 6 & $5.09 * *$ & -- & 4 & $2.13(P=0.09)$ & -- \\
\hline Stage*Sex & 1 & 0.05 & -- & 1 & 1.33 & -- \\
\hline Stage*Station*Sex & 1 & 0.19 & -- & 1 & $5.47 *$ & -- \\
\hline Error & 175 & -- & -- & 56 & -- & -- \\
\hline
\end{tabular}


Table 17. Results of preliminary analysis-of-variance investigating the effects of various factors on biomarker ${ }^{a}$ responses in carp and bass (Micropterus sp.) from the Rio Grande Basin. Shown are degrees-of-freedom (df), $F$-values with significance levels $\left({ }^{*} 0.01<P \leq 0.05 ;{ }^{* *} P \leq 0.01\right)$, and coefficients of determination $\left(R^{2}\right)$.-Continued

\begin{tabular}{|c|c|c|c|c|c|c|}
\hline \multirow{2}{*}{$\begin{array}{l}\text { Variable, source, and } \\
\text { (transformation) }\end{array}$} & \multicolumn{3}{|c|}{ Carp } & \multicolumn{3}{|c|}{ Bass } \\
\hline & $\mathrm{df}$ & $F$ & $R^{2}$ & $d f$ & $F$ & $R^{2}$ \\
\hline \multicolumn{7}{|l|}{$\operatorname{Vtg}^{\mathrm{b}}(\log )$} \\
\hline Model & 25 & $19.01^{* *}$ & 0.87 & 17 & $3.50 * *$ & 0.71 \\
\hline Station & 1 & 0.77 & -- & 3 & 0.67 & -- \\
\hline Stage & 1 & $31.14 * *$ & -- & 1 & 0.31 & -- \\
\hline Stage* Station & 1 & $13.58 * *$ & -- & 3 & 0.30 & -- \\
\hline Age & 1 & \multicolumn{2}{|l|}{$1.97(P=0.17)$} & 1 & 0.17 & -- \\
\hline Age*Station & 1 & 0.09 & -- & 3 & 1.28 & -- \\
\hline Stage*Age & 1 & $12.97 * *$ & -- & 1 & $<0.01$ & -- \\
\hline Stage*Age*Station & 1 & $3.88^{*}$ & -- & 3 & 0.80 & -- \\
\hline Error & 69 & -- & -- & 23 & -- & -- \\
\hline
\end{tabular}

${ }^{a}$ EROD, ethoxyresorufin $O$-deethylase activity; $\mathrm{CF}$, condition factor; SSI, splenosomatic index; HSI, hepatosomatic index; HAI, health assessment index; TICCOC, percent splenic tissue occupied by macrophage aggregates (MA); MEANAREA, mean area of splenic MA; MAMM, density of splenic MA; GSI, gonadosomatic index; Vtg, plasma vitellogenin concentration.

${ }^{\mathrm{b}}$ Only female fish included in analysis

1996a; Schlenk and others, 1996b; Schmitt and others, 2002c; Whyte and others, 2000). Of 30 male bass analyzed, only two had EROD rates $<20.0 \mathrm{pmol} / \mathrm{min} / \mathrm{mg}$ (Fig. 10). EROD expression in all stage- 1 males was $\geq 33.5 \mathrm{pmol} / \mathrm{min} / \mathrm{mg}$ with a basin-wide mean of $73.2 \mathrm{pmol} / \mathrm{min} / \mathrm{mg}$ (Appendix Table 4). EROD rates were $\geq 13.0 \mathrm{pmol} / \mathrm{min} / \mathrm{mg}$ protein in all stage-2 males with a basin-wide mean of $55.3 \mathrm{pmol} / \mathrm{min} / \mathrm{mg}$, and the rate in one stage- 3 male bass from Station 514 was $55.6 \mathrm{pmol} /$ $\mathrm{min} / \mathrm{mg}$ (Appendix Table 4). Station means for EROD activity ranged from $17.6 \mathrm{pmol} / \mathrm{min} / \mathrm{mg}$ at Station 514 (all stage 2) to $78.2 \mathrm{pmol} / \mathrm{min} / \mathrm{mg}$ at Station 512 (also stage 2; Fig. 10; Table 18). Mean EROD activity in male bass exceeded background rates at Stations 16 (stage 1, 33.5 pmol/min/mg; stage 2, $62.3 \mathrm{pmol} / \mathrm{min} / \mathrm{mg}$ ) and 513 (stage $2,56.7 \mathrm{pmol} / \mathrm{min} / \mathrm{mg}$ ). In addition, elevated EROD rates $(62.9-129.8 \mathrm{pmol} / \mathrm{min} / \mathrm{mg}$ ) were detected in two male bass from Station 63 and in one of unknown gender and stage from Station 512 (Fig. 10; Appendix Table 4). EROD activity in some of the male bass from Stations 16, 513, and 512 was about the same as in those from the most contaminated MRB sites sampled in 1995 by Schmitt and others (2002c). No male bass were obtained from Station 63 , however.

\section{EROD in other fishes}

In addition to carp and bass, EROD activity was measured in 47 fish representing five other species (channel catfish, blue catfish, northern pike, white bass, and striped bass) from five of the 10 stations sampled (Table 18). Extant data are available for comparison with all of these species except blue catfish (Schmitt and others, 2002c; Whyte and others, 2000). Channel catfish were obtained from Stations 511 and 516. At Station 511, EROD activity was 17.8-71.7 $\mathrm{pmol} / \mathrm{min} / \mathrm{mg}$ in females, $12.8-27.9 \mathrm{pmol} / \mathrm{min} / \mathrm{mg}$ in males, and $18.9-110.5 \mathrm{pmol} / \mathrm{min} / \mathrm{mg}$ in juveniles (Table 18). These values are substantially greater than the $0.4-14.2 \mathrm{pmol} / \mathrm{min} / \mathrm{mg}$ reported for channel catfish $(n=6)$ collected in 1995 from two stations in the Missouri River sub-basin of the MRB (Schmitt and others, 2002c), and is further evidence of exposure of fish to exogenous Ah-R agonists at Station 511. EROD rates in channel catfish from Station 516 were generally lower than those from Station 511 (Table 18), but were nevertheless greater than 1995 values for this species (Schmitt and others, 2002c) and therefore suggests some degree of exposure to Ah-R agonists at Station 516 as well. EROD rates in blue catfish $(n=6)$, which were obtained only at Station 515 , were 7.2-17.2 $\mathrm{pmol} / \mathrm{min} / \mathrm{mg}$ (Table 18). These rates are within the range of those in the congeneric channel catfish from Stations 511 and 516, but there are no extant data for comparison in this species. Northern pike were obtained only from Station 64; EROD activity was $0.4-1.8 \mathrm{pmol} / \mathrm{min} / \mathrm{mg}$ in females and 0.2-2.3 in males (Table 18). These values are almost identical to those reported for northern pike from a site on the Missouri River in North Dakota sampled in 1995 (Schmitt and others, 2002c) and, like the 1995 values, are about 10-fold lower than previously reported basal EROD rates for this species (Förlin and Celander, 1993; Williams and others, 1997). EROD activity in white bass, which were obtained exclusively at Station 65 , were $2.5-18.1 \mathrm{pmol} / \mathrm{min} / \mathrm{mg}$ in females and 2.8-8.4 $\mathrm{pmol} / \mathrm{min} / \mathrm{mg}$ in males (Table 18). These values are similar to those observed in white bass and striped bass $\mathrm{X}$ white bass hybrids obtained from the lower Mississippi River in 1995 (Schmitt and others, 2002c), but basal rates in this species have not been determined (Whyte and others, 2000). A laboratory study (Shayne Washburn and others, 1996) indicated a low level of basal EROD activity $(1.2 \mathrm{pmol} / \mathrm{min} / \mathrm{mg})$ in the congeneric striped bass; however, the 1997 results suggest that the fish from Station 65 had been exposed to exogenous AhR agonists. The only striped bass collected in the RGB 


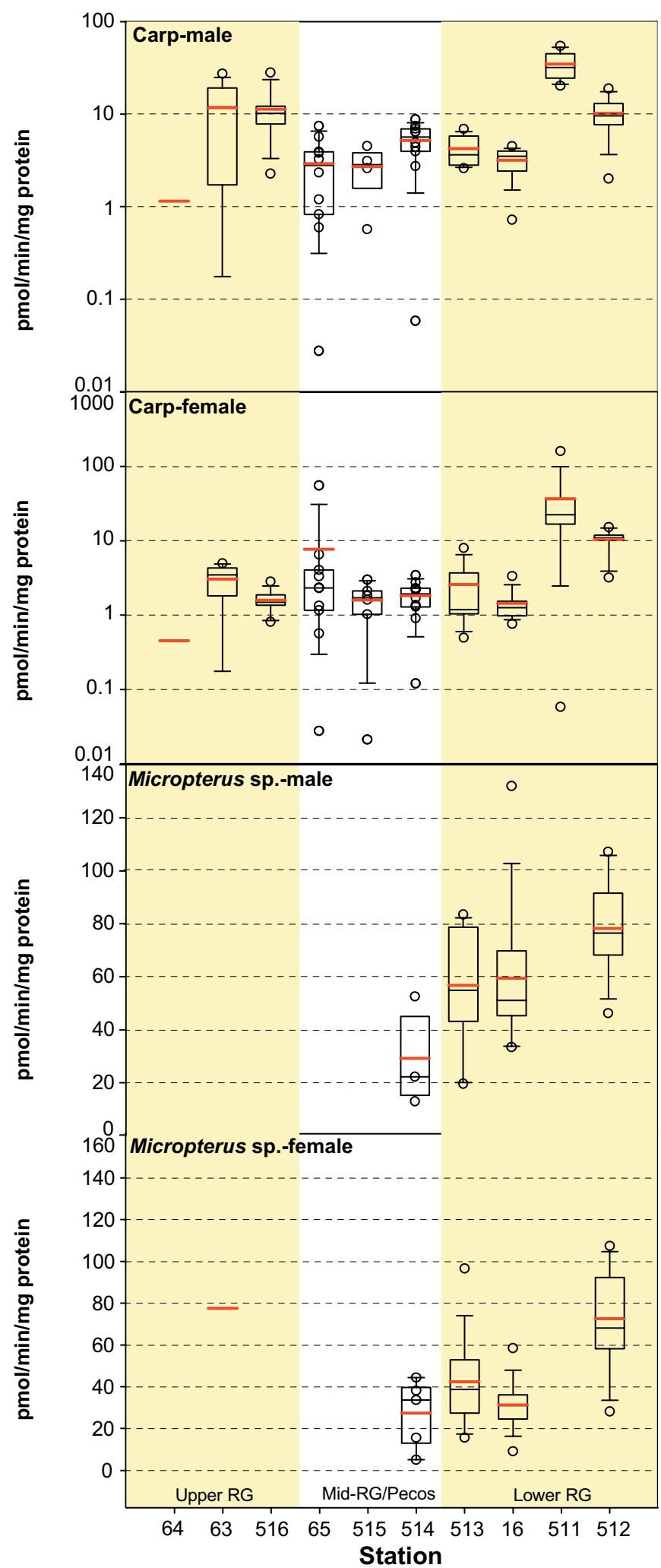

Figure 10. Hepatic EROD activity in male and female carp and bass (Micropterus sp.), by station. Shown for each group are points representing individual fish and the mean (red horizontal line), median (black horizontal line), interquartile range (box), and the 10th and 90th percentiles (whiskers). Stations are ordered from upstream to downstream and are grouped by sub-basin. See Table 1 for station descriptions and collection dates. (from Station 63) had a very low level of EROD activity $(<0.1$ $\mathrm{pmol} / \mathrm{min} / \mathrm{mg}$; Table 18).

\section{Accumulative Contaminants, H4IIE, and EROD: Summary}

Among the elemental contaminants measured in 1997, only $\mathrm{Hg}$, As, and Se concentrations were elevated, and all had been documented previously in the RGB. Concentrations of the other elements measured were either generally low or elevated in relatively few samples (for example, $\mathrm{Pb}$ in one bass sample from Station 16). Elevated concentrations of $\mathrm{Hg}$ and $\mathrm{Se}$ are well documented in the RGB; these elements are suspected of being involved in the reproductive failure of peregrine falcons in Trans-Pecos Texas (Mora and others, 2002). Concentrations of $\mathrm{Hg}$ in bass collected in 1997 from Station 63 were $0.30-0.50 \mu \mathrm{g} / \mathrm{g}$, levels that are potentially toxic to piscivorous wildlife and consistent with the present consumption advisory for Elephant Butte Reservoir. Concentrations were lower, but nevertheless elevated relative to most sites, in other predatory fishes from Station 63. Concentrations of $\mathrm{Hg}$ were comparatively low in fish from Station 515, which is downstream from BBNP and the Terlingua cinnabar mining district of Trans-Pecos Texas. Elevated concentrations of $\mathrm{Hg}$ were also detected in bass from Station 514 (Amistad Dam), which is further downstream, and at Station 16 (RG at Mission, Texas). In the past, elevated $\mathrm{Hg}$ concentrations were also reported in fish from the RG at El Paso (USEPA, 1992b), but 1997 concentrations at Station 516 were universally $<0.06$ $\mu \mathrm{g} / \mathrm{g}$ (Fig. 3). Overall, $\mathrm{Hg}$ concentrations in bass from the RGB were generally similar to those collected from the MRB in 1995 (Schmitt and others, 2002c). Temporal trends in $\mathrm{Hg}$ concentrations were not clearly evident in the RGB, and both temporal and geographic differences were confounded to some degree by fish size differences.

Comparatively high concentrations of Se $(>1.0 \mu \mathrm{g} / \mathrm{g})$ characterized fish from Stations 65, 514, and 515 (Fig. 2) and confirmed previous findings for the central parts of the RGB; however, the 1997 Se concentration in Morone sp. from Station 65 was significantly lower in 1997 than in previous NCBP collections (Schmitt and others, 1999b). In addition, Se concentrations in all RGB fish were considerably lower than the 3-5 $\mu \mathrm{g} / \mathrm{g}$ reported for a site in the MRB with a history of contamination from irrigated agriculture (Schmitt and others, 2002c). Nevertheless, mean concentrations at Stations 65,514 , and 515 and individual fish from several other sites exceeded the $0.8 \mu \mathrm{g} / \mathrm{g}$ threshold for fish toxicity and 0.6 $\mu \mathrm{g} / \mathrm{g}$ for wildlife proposed by Lemly $(1996 ; 2002)$. Naturally occurring Se mobilized by irrigated agriculture is among the contaminants suspected in the reproductive failure of peregrine falcons in Trans-Pecos Texas (Mora and others, 2002), as noted in the preceding paragraph. 
Table 18. Geometric means and ranges of EROD activities (pmol/min/mg protein), by species, station and gender. Censored values were represented by $50 \%$ of the limit-of-quantitation in the computation of geometric means. See Table 1 for station locations and collection dates.

\begin{tabular}{|c|c|c|c|c|c|c|c|c|c|}
\hline \multirow{2}{*}{$\begin{array}{l}\text { Species and } \\
\text { station }\end{array}$} & \multicolumn{3}{|c|}{ Female } & \multicolumn{3}{|c|}{ Male } & \multicolumn{3}{|c|}{ Juvenile $^{a}$} \\
\hline & $n$ & Range & Mean & $n$ & Range & Mean & $n$ & Range & Mean \\
\hline \multicolumn{10}{|l|}{ Common carp } \\
\hline 16 & 10 & $0.76-3.35$ & 1.31 & 10 & $0.72-4.47$ & 2.89 & 0 & -- & -- \\
\hline 63 & 8 & $0.18-4.95$ & 1.81 & 9 & $0.18-27.2$ & 4.76 & 0 & -- & -- \\
\hline 64 & 19 & $0.07-2.72$ & 0.25 & 14 & $0.08-7.84$ & 0.34 & 1 & -- & 0.07 \\
\hline 65 & 10 & $0.03-55.5$ & 1.90 & 10 & $0.03-7.38$ & 1.54 & 0 & -- & -- \\
\hline 511 & 13 & $0.06-161.1$ & 16.8 & 7 & $20.1-54.2$ & 32.6 & 0 & -- & -- \\
\hline 512 & 6 & $3.19-15.1$ & 9.44 & 8 & $2.0-18.8$ & 8.70 & 0 & -- & -- \\
\hline 513 & 11 & $0.49-7.98$ & 1.80 & 9 & $2.58-6.88$ & 3.97 & 0 & -- & -- \\
\hline 514 & 10 & $0.12-3.42$ & 1.42 & 10 & $0.06-8.74$ & 3.46 & 0 & -- & -- \\
\hline 515 & 6 & $0.02-2.98$ & 0.86 & 4 & $0.57-4.50$ & 2.13 & 0 & -- & -- \\
\hline 516 & 10 & $0.81-2.83$ & 1.49 & 8 & $2.26-28.0$ & 9.24 & 0 & -- & -- \\
\hline \multicolumn{10}{|l|}{$\begin{array}{l}\text { Largemouth } \\
\text { bass }\end{array}$} \\
\hline 16 & 11 & $9.09-58.5$ & 28.6 & 10 & $33.5-132$ & 54.8 & 0 & -- & -- \\
\hline 63 & 4 & $38.5-81.0$ & 57.7 & 0 & -- & -- & 2 & $62.9-130$ & 90.3 \\
\hline 512 & 7 & 28.1-107 & 67.4 & 8 & $46.2-107$ & 75.9 & 1 & -- & 111.2 \\
\hline 513 & 13 & $15.5-96.6$ & 37.2 & 9 & $19.7-83.5$ & 50.6 & 0 & -- & -- \\
\hline 514 & 5 & $5.00-44.3$ & 21.3 & 2 & $13.0-22.3$ & 17.0 & 0 & -- & -- \\
\hline \multicolumn{10}{|l|}{$\begin{array}{l}\text { Smallmouth } \\
\text { bass }\end{array}$} \\
\hline 63 & 2 & $79.6-147$ & 108 & 0 & -- & -- & 0 & -- & -- \\
\hline 514 & 0 & -- & -- & 1 & -- & 52.6 & 0 & -- & -- \\
\hline \multicolumn{10}{|l|}{ Striped bass } \\
\hline 63 & 1 & -- & $<0.1$ & 0 & -- & -- & 0 & -- & -- \\
\hline \multicolumn{10}{|l|}{ White bass } \\
\hline 65 & 18 & $2.50-22.4$ & 9.52 & 3 & $2.77-8.36$ & 4.34 & 0 & -- & -- \\
\hline \multicolumn{10}{|l|}{ Blue catfish } \\
\hline 515 & 3 & $7.19-17.2$ & 10.3 & 0 & -- & -- & 3 & $9.75-12.2$ & 11.0 \\
\hline \multicolumn{10}{|l|}{ Channel catfish } \\
\hline 511 & 8 & $17.9-71.7$ & 40.6 & 3 & $12.8-27.9$ & 20.3 & 9 & $18.9-111$ & 38.9 \\
\hline 516 & 11 & $6.12-23.1$ & 12.2 & 2 & $15.8-19.5$ & 17.5 & 9 & $9.3-25.4$ & 14.1 \\
\hline \multicolumn{10}{|l|}{ Northern pike } \\
\hline 64 & 6 & 0.14-1.77 & 0.52 & 10 & $0.18-2.30$ & 0.69 & 0 & -- & -- \\
\hline
\end{tabular}

${ }^{a}$ May include fish of undetermined gender from which no gonad sample was obtained.

Arsenic and Se concentrations are naturally elevated in some parts of the RGB, and these high background concentrations are reflected in fish. In addition, naturally occurring concentrations may be further increased by leaching due to irrigation, and As is discharged from sewage treatment plants where groundwater is rich in As (Wilcox, 1997). Arsenic is released during the smelting of metals, and both As and Se are released during the combustion of fossil fuels. Arsenic-containing pesticides and defoliants are also used extensively in parts of the RGB, and As accumulates in planktivorous fishes and higher trophic level species that consume them. Consistent with previous studies, As concentrations were comparatively high $(0.37-0.55 \mu \mathrm{g} / \mathrm{g})$ in carp and other fishes from Stations 65 and 514; comparable concentrations were reported in fish collected from the southwestern parts of MRB in 1995 (Schmitt and others, 2002c). At least one 1997 sample from every station except 64 contained $>0.2 \mu \mathrm{g} / \mathrm{g}$. The As in fish from the RGB is not considered a hazard to the fish or to fisheating wildlife based on current criteria. Other than As and
$\mathrm{Hg}$, concentrations of elemental contaminants associated with mining were comparatively low, even at Station 64. This site is downstream from the Crede, Colorado mining district where elevated metals from historical mining and related activities have been reported in the past.

Comparatively high concentrations of the organochlorine pesticides DDT (as $p, p$ '-DDE), chlordane, dieldrin, and toxaphene were detected in fish from at least one site in the lower RGB, which also generally confirmed the findings of previous and contemporaneous investigations. No other residues were detected. Although concentrations were lower than in the past, residues derived from DDT continued to be detected throughout the RGB in 1997. Most of this material was $p, p$ '-DDE, indicating weathered insecticide rather than the influx of new material. Concentrations remained sufficiently high to represent a threat to fish-eating birds. At least one sample from Stations 16, 513, and 516 contained $>0.15$ $\mu \mathrm{g} / \mathrm{g}$, and all channel catfish samples from Station 511 (AC at Harlingen) contained 1-2 $\mu \mathrm{g} / \mathrm{g}$, which is within the range 
of toxicity for most avian wildlife (Blus, 1996). Except for Station 516, residues in fish from the upper RGB were low, as they also were in 1992 samples from the upper RGB analyzed by NAWQA (Carter and Anderholm, 1997; Levings and others, 1998). In contrast, concentrations at Station 16, on the lower RG, remained relatively high $(0.32-0.52 \mu \mathrm{g} / \mathrm{g})$ in 1997. Nevertheless, these levels represent a substantial decrease since the 1980s, when they were consistently $>1.0 \mu \mathrm{g} / \mathrm{g}$ (Schmitt and others, 1999b). In general, 1997 findings for DDT in the lower RGB and at El Paso confirmed the results of other recent investigations of this area (Davis and others, 1995; Moring, 1999; TNRCC, 1994b; 1997; USEPA, 1992b; Wainwright and others, 2001), and the AC and nearby waters remain under a fish consumption advisory.

Chlordane was among the few other organochlorine chemical residues detected at potentially toxic concentrations in 1997. During the 1970s, traces of chlordane components $(\leq 0.01-0.3 \mu \mathrm{g} / \mathrm{g})$ were detected in some samples from Stations 63, 64, and 65 (Schmitt and others, 1999b) but a trend toward non-detections that began in the 1980s continued through 1997 at these stations; concentrations of all six components measured were $<0.01 \mu \mathrm{g} / \mathrm{g}$ in all samples. Traces of chlordane constituents were detected in fish samples from some sites in the upper RGB sampled during the 1980s and early 1990s (Carter and Anderholm, 1997; Levings and others, 1998; Ong and others, 1991). At Station 16, concentrations of chlordane components ranged from $<0.005$ to $0.09 \mu \mathrm{g} / \mathrm{g}$ in NCBP collections, but 1997 concentrations were slightly lower; all component concentrations were $\leq 0.01 \mu \mathrm{g} / \mathrm{g}$ except for two trans-nonachlor values. In contrast, 1997 chlordane concentrations were $>0.1 \mu \mathrm{g} / \mathrm{g}$ in fish from Station 511, where they were also elevated in all recent and contemporaneous studies (Davis and others, 1995; TNRCC, 1994b; USEPA, 1992b). Like DDT, chlordane is part of the consumption advisory for fish from these waters, and 1997 concentrations remained sufficiently elevated to also represent a threat to fish-eating wildlife. The chlordane residues in fish from Station 511 were similar in concentration and composition to those in fish from agricultural regions of the MRB sampled in 1995 (Schmitt and others, 2002c).

Toxaphene concentrations were historically elevated in the lower RGB, but levels in the upper basin were low; concentrations did not exceed $0.3 \mu \mathrm{g} / \mathrm{g}$ at Stations 63, 64, and 65 during the 1970s, and levels in all but one sample collected in the $1980 \mathrm{~s}$ were $\leq 0.1 \mu \mathrm{g} / \mathrm{g}$. In 1997, toxaphene was not detected at these sites, nor were residues detected in fish collected from the upper RGB in 1986-1992 (Carter and Anderholm, 1997; Levings and others, 1998; Ong and others, 1991) or from the transboundary segments of the RG during the mid-1990s (TNRCC, 1994b; 1997). In contrast, toxaphene concentrations at Station 16 were elevated in the 1970 s $(0.3-$ $1.4 \mu \mathrm{g} / \mathrm{g}$ ) but decreased through the $1980 \mathrm{~s}$ (to $0.2-0.3 \mu \mathrm{g} / \mathrm{g}$ in 1986). Wainwright and others (2001) also reported concentrations as great as $0.3 \mu \mathrm{g} / \mathrm{g}$ in carp from resacas and settling basins and as much as $4.4 \mu \mathrm{g} / \mathrm{g}$ in greenback heron eggs. All 1997 samples from Station 16 contained $\leq 0.11 \mu \mathrm{g} / \mathrm{g}$; however, toxaphene concentrations were $0.5-2.5 \mu \mathrm{g} / \mathrm{g}$ in fish from Station 511, which is consistent with recently reported concentrations at this site (Davis and others, 1995; TNRCC, 1994b; 1997). These values are also similar to those in fish collected from cotton-farming regions of the MRB in 1995 (Schmitt and others, 2002c) and may be sufficiently high to represent a threat to fish; however, the toxicity of weathered toxaphene is highly variable and cannot be determined from the 1997 data. Toxaphene is also a component of the consumption advisory for fish from the AC and nearby waters.

In 1997, PCBs were not detected in any samples from the RGB and the greatest TCDD-EQ concentrations were only 3-6 $\mathrm{pg} / \mathrm{g}$ (in fish from Stations 511 and 512). Concentrations of TCDD-EQ at reference sites in previous studies ranged from below detection to $6 \mathrm{pg} / \mathrm{g}$ (Giesy and others, 1995; Schmitt and others, 2002c; van den Heuvel and others, 1996; Whyte and others, 2004), and $6 \mathrm{pg} / \mathrm{g}$ was suggested as a threshold for toxicity to fish-eating wildlife (Giesy and others, 1995). These results were consistent with recent and historical findings of low levels of PCB and dioxin contamination in the RGB (Carter and Anderholm, 1997; Levings and others, 1998; Ong and others, 1991; Schmitt and others, 1999b; TNRCC, 1994b; 1997; USEPA, 1992b; Wainwright and others, 2001), and indicate minimal risk to wildlife from TCDD and similar compounds.

Based on data from the 1995 MRB study and an extensive review of the literature (Schmitt and others, 2002c; Whyte and others, 2000) considered $0-4 \mathrm{pmol} / \mathrm{min} / \mathrm{mg}$ to be the normal range of EROD expression in female carp and 0-6 pmol/ $\mathrm{min} / \mathrm{mg}$ the normal range in male carp. The normal range for bass was considered 0-16 pmol/min/mg in females and 0-22 $\mathrm{pmol} / \mathrm{min} / \mathrm{mg}$ in males. Relative to these ranges, EROD rates were induced above basal levels and therefore indicative of exposure to exogenous AhR agonists at all stations and were greatest at Stations 511 and 512. Although basal rates have not been determined for channel catfish, EROD rates were also greater than those observed in other studies and at other RGB stations in channel catfish from Station 511. Rates also exceeded basal levels in male carp from Stations 63 and 516, in one female carp from Station 65, and possibly also in white bass from Station 65 (basal rates have not been determined in this species). EROD rates in individual male and female bass were elevated at Stations 512 and Station 513; in bass (female and unknown gender) from Station 63; and in male bass from Station 16. In addition, there was a general gradient of increasing EROD activity from upstream to downstream. Considering the low concentrations of total PCBs and TCDDEQ at all sites, the EROD findings suggest that some fish from all RGB stations had been exposed to PAH. Moring (1999) detected PAH in SPMD samples from five of the six transboundary RG stations sampled in July-August 1997, and both concentrations and numbers of compounds detected also generally increased from upstream to downstream. Although PAH emanate from a variety of sources (Schmitt, 1998), the extensive oil and gas extraction and transportation industry of the RGB cannot be overlooked as a potential source. 


\section{Fish Health Indicators}

\section{Organism-Level Indicators}

\section{External Gross Lesions}

Of the 368 fish examined, $28 \%$ had some type of external lesion (Table 19). Lesion frequencies ranged from $2 \%$ at Station 65 to $75 \%$ at Station 515. Of the 207 carp examined, $29 \%$ had external lesions. Percentages were lowest at Stations 16, 65, and 512 and highest at Stations 516 and 515 (Table 19). Carp from Station 65 were notable for a lack of external lesions $(0 \%)$ whereas the percent occurrence at Station 515 was 3-9 times greater than that at most other stations (Table 19). In bass, $27 \%$ had external lesions. Percentages were lowest at Stations $16(1 \%)$ and $513(14 \%)$ and were $\geq 50 \%$ at Stations 512 and 514 (Table 19).

External lesions were not analyzed statistically. Overall, percentages of external lesions for carp and bass were similar to each other and to the percentage for all fish (Table 19). Greater percentages of bass from Stations 512 and 514 than from Stations 16, 63, and 514 had lesions (Table 19). As noted, the greatest percentages of all fish and of carp with lesions were from Station 515, but bass were not collected there. Lesions occurred most commonly on bass $(\geq 50 \%)$ at Stations 512 and 514 whereas the occurrence on carp was low (7\%) at Station 512 and similar to the basin average at Station 514 (Table 19). No other taxa were collected at the latter two stations, however. The incidence of external lesions on carp and bass from Station 16 and carp and white bass from Station 65 was also low (Table 19).

Overall, the percentages of fish with external lesions were similar to what was reported for the MRB in 1995 (Blazer and others, 2002), which were generally higher than the proportions reported by other studies. However, and as noted by Blazer and others (2002), external lesion frequencies are difficult to compare because protocols differ among investigators. As also reported for the MRB, most external lesions were identified as eroded, frayed, or hemorrhagic fins. Tissues from a total of 24 external lesions (16 from carp, eight from bass) were fixed and analyzed microscopically; most were identified as inflammatory responses, often associated with parasites. Two carp from Station 515 had unusual inflammatory reactions in the epidermis or hypodermis associated with refractile, crystalline material (Fig. 11). In addition, two carp from each of Stations 516 and 514 had papillomas of the body surface or oral cavity (Fig. 11).

\section{Health Assessment Index}

Statistically significant ANOVA models that included the factors station, gender, stage, and their interactions accounted for $28 \%$ of the total HAI variation (rank-transformed) in carp and $41 \%$ in bass (Table 17). Differences among gonadal stages were statistically significant in both taxa, as was the interaction of station, stage, and sex in bass (Table 17). However, after accounting for all other effects, differences among stations were not significant in carp and only approached significance $(P=0.11)$ in bass; differences between genders were not significant in either taxon (Table 17). These results are similar, but not identical, to those obtained from the analysis of the much larger $1995 \mathrm{MRB}$ data set (Blazer and others, 2002) in which differences between carp genders were also detected. Results for male and female fish were nevertheless combined for presentation.

Overall, HAI scores for carp and bass were distributed similarly. Most (90\%) of the scores for carp ranged from 20 to 90, indicating that the fish had 1-3 lesions (Fig. 12; Table 20). The basin-wide mean HAI score was 46 and all station means

Table 19. Percentages (\%) of carp, bass (Micropterus spp.), and all fish from the Rio Grande Basin with external lesions, by station. Also shown are the numbers of fish with lesions (EL) and of fish in each category examined $(n)$. See Table 1 for station locations and collection dates.

\begin{tabular}{|c|c|c|c|c|c|c|c|c|c|}
\hline \multirow{2}{*}{ Station } & \multicolumn{3}{|c|}{ Carp } & \multicolumn{3}{|c|}{ Bass } & \multicolumn{3}{|c|}{ All fish } \\
\hline & $n$ & $\mathrm{EL}$ & $\%$ & $n$ & EL & $\%$ & $n$ & EL & $\%$ \\
\hline 16 & 20 & 2 & 10 & 21 & 2 & 10 & 41 & 4 & 10 \\
\hline 63 & 25 & 8 & 32 & 8 & 2 & 25 & 34 & 10 & 29 \\
\hline 64 & 40 & 14 & 35 & 0 & 0 & 0 & 56 & 26 & 46 \\
\hline 65 & 20 & 0 & 0 & 0 & 0 & 0 & 41 & 1 & 2 \\
\hline 511 & 20 & 6 & 30 & 0 & 0 & 0 & 40 & 9 & 23 \\
\hline 512 & 14 & 1 & 7 & 16 & 9 & 56 & 30 & 10 & 33 \\
\hline 513 & 20 & 6 & 30 & 22 & 3 & 14 & 42 & 9 & 21 \\
\hline 514 & 20 & 6 & 30 & 8 & 4 & 50 & 28 & 10 & 36 \\
\hline 515 & 10 & 9 & 90 & 0 & 0 & 0 & 16 & 12 & 75 \\
\hline 516 & 18 & 8 & 44 & 0 & 0 & 0 & 40 & 12 & 30 \\
\hline Total & 207 & 60 & 29 & 75 & 27 & 27 & 368 & 103 & 28 \\
\hline
\end{tabular}



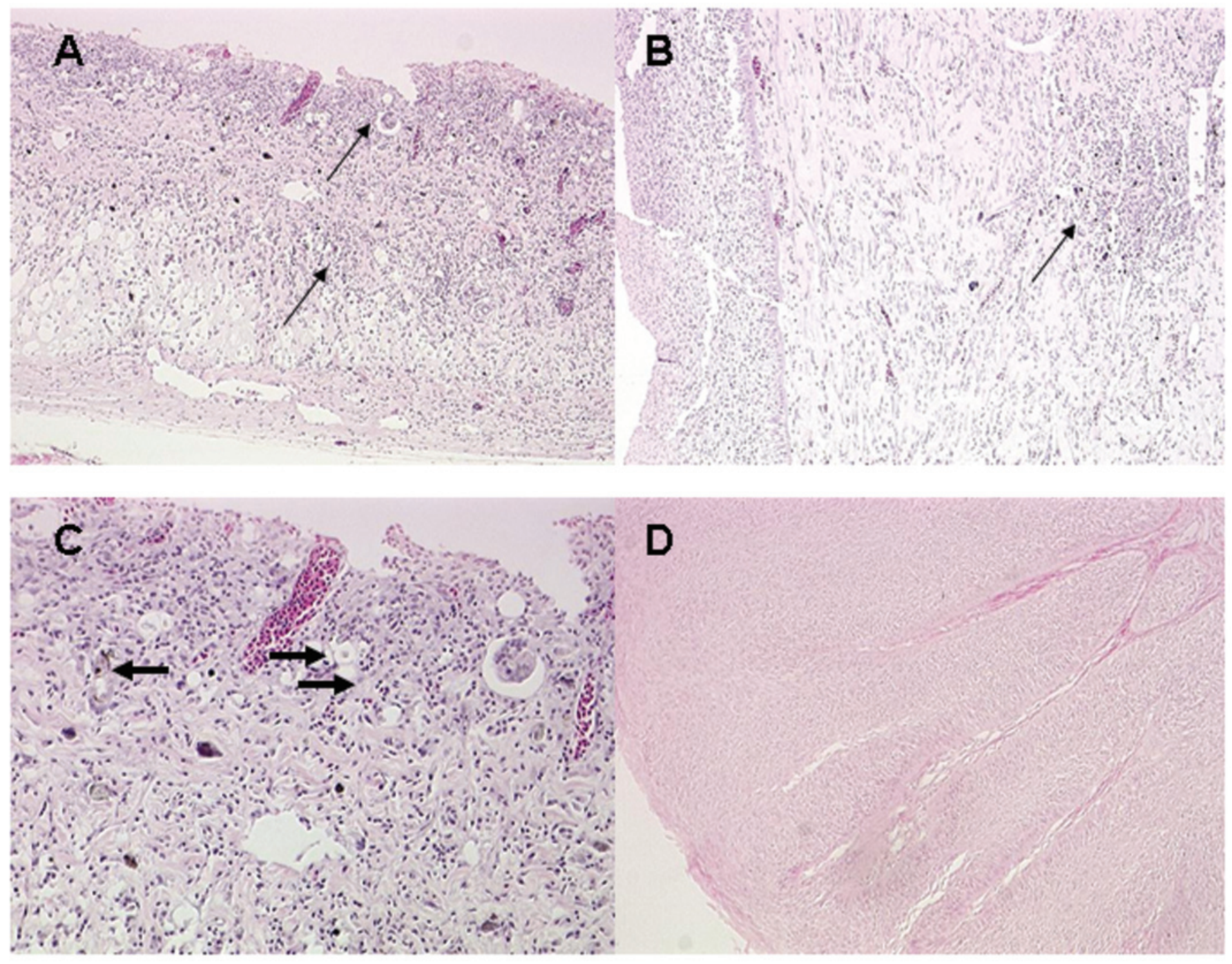

Figure 11. Histologic appearance of external gross lesions observed in carp from the Rio Grande Basin. Inflammatory responses included chronic inflammation (thin arrows) throughout a thickened epidermis (A) and within the dermis (B) of carp from Station 515. H \& E stain (X 165). C. Higher magnification (X 412) of a portion of (A) illustrating the refractile, crystalline material that appears to elicit this inflammatory response (thick arrows). D. Papilloma in carp from Station 514. H \& E stain (X 165).

were between 30 and 70 except for Station 65 (mean = 28; Fig. 12). Station means for carp were $>60$ at Stations 511 and 515 , indicating that these fish had, on average, two external lesions. Except for Station 515, 80-100\% of the carp from each station received ratings $<100$, indicative of three or fewer abnormalities (Fig. 12; Table 20). For bass, most HAI scores (90\%) were between 10 and 110, indicative of 1-5 abnormal ratings (Fig. 12; Table 20). The basin-wide mean for bass was 53 , but the only station mean $<50$ was for Station 512 (mean $=33$; Fig. 12). Means for Stations 514 and 63 were $>60$, and no individual bass from these sites scored $<40$. The lowest mean HAI score for carp was at Station 65; for bass Station 512 was lowest (Fig. 12). Mean HAI scores were $>60$ for bass from Stations 514 and 63. The greatest means for carp and bass did not occur at the same stations; however, bass were not collected at Stations 511 or 515, where scores in carp were generally greatest.

The HAI had not been used to evaluate carp prior to the 1995 MRB study (Schmitt, 2002a). In contrast, HAI had been used to evaluate largemouth bass in several previous investigations (Adams and others, 1993; Coughlan and others, 1996). Based on these previous studies, Blazer and others (2002) considered an HAI score $\leq 20$ as indicative of an unimpacted or minimally impacted site. Relative to this value, most of the individual fish and all carp and bass station means indicated some impact. Although the overall range and distribution of HAI scores in carp and bass from the RGB were similar to those reported for the MRB 1995 (Blazer and others, 2002), fish from greater percentage of RGB stations had scores $>20$. 


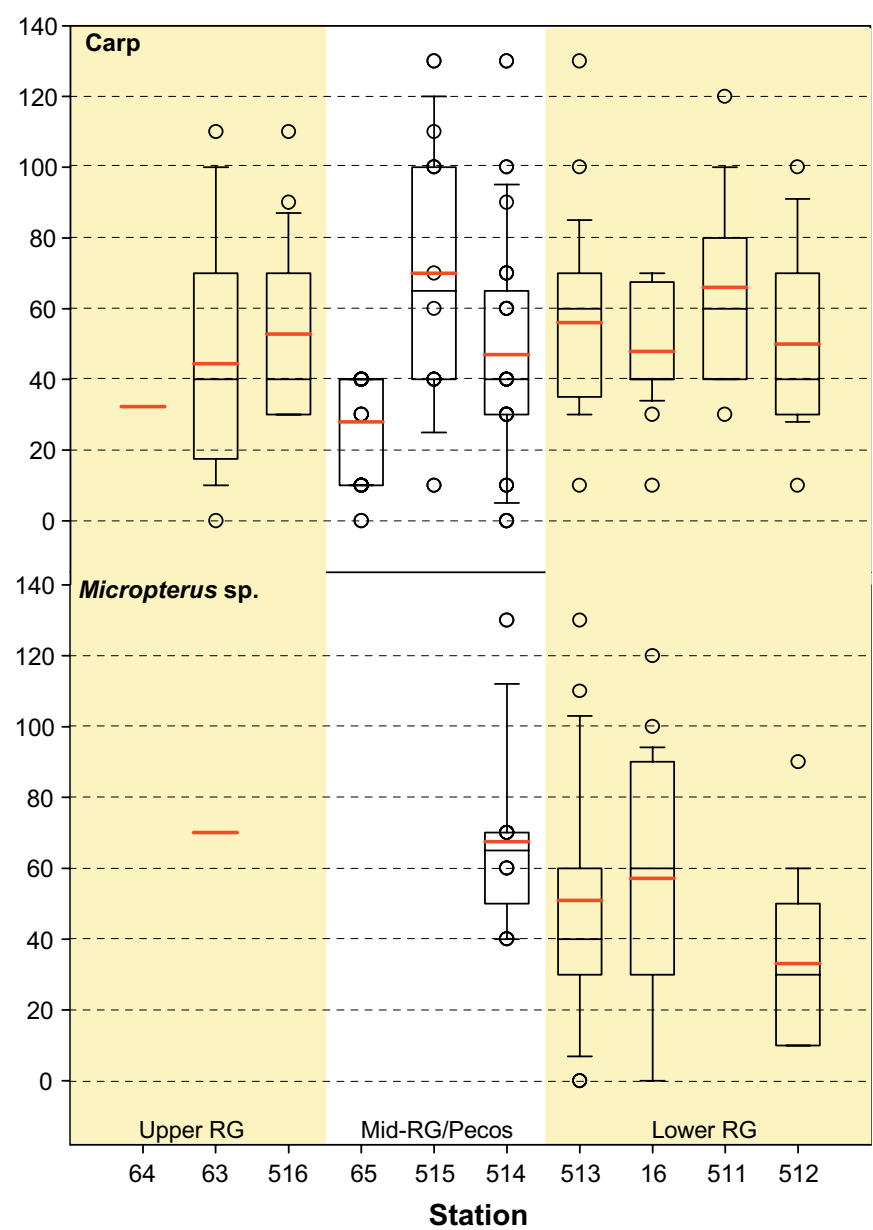

Figure 12. Health Assessment Index (HAl) scores of male and female carp and bass (Micropterus sp.), by station. Shown for each group are points representing individual fish and the mean (red horizontal line), median (black horizontal line), interquartile range (box), and the 10th and 90th percentiles (whiskers). Stations are ordered from upstream to downstream and are grouped by sub-basin. See Table 1 for station descriptions and collection dates

\section{Condition and Organosomatic Indices}

\section{Condition Factor}

An ANOVA model that included station, sex, stage, and all interactions of these factors was highly significant in bass and explained 78\% of the variation in CF (Table 17). In contrast, no CF differences in carp were statistically significant, and these factors combined accounted for only $9 \%$ of the variation (Table 17). These results are consistent with results obtained for the larger 1995 data set for the MRB (Blazer and others, 2002). Data were therefore combined for carp, but are presented separately for bass (Fig. 13). The basin-wide mean CF for RGB carp was 1.4. Station means ranged from 1.2 (Stations 63 and 512) to 1.6 (Stations 513 and 514) (Fig. 13); however, $\mathrm{CF}$ in carp did not differ significantly among stations
(Table 17). Across all stations, $90 \%$ of carp CFs were between 1.1 and 1.8 (Fig. 13). Individual values of 0.7-0.9 occurred at Stations $16,63,511$, and 516 , whereas values $>2.0$ occurred at Stations 64, 511, and 514 (Fig. 13). Station means and individual values were generally similar to previously published CFs in carp from other locations (BEST Program, unpublished data from the Columbia River Basin; Blazer and others, 2002; Carlander, 1969; Solé and others, 2002), but individual values $>2.0$ are unusual and indicate rapid growth.

In contrast to carp, among-station differences for $\mathrm{CF}$ in bass were statistically significant (Table 17). The basin-wide mean was 1.5 , with station means ranging from 1.4 at Stations 16 and 63 to 1.8 at Station 514 (Fig. 13). For the RGB, 90\% of the bass examined had CF values between 1.2 and 2.0 (Fig. 13), and the among-station and between-gender differences appear to have been heavily influenced by two widely separate values, both in males: the CF of one fish from Station 513 was only 0.9 whereas one from Station 514 was 3.5 (Fig. 13). All other $\mathrm{CF}$ values were more uniform, and differences among stations were small. The means and individual CFs of RGB bass were generally similar to previously reported values for other locations, but means $>1.6$ and individual values $>2.0$ are unusual (BEST Program, unpublished data from the Columbia River Basin; Blazer and others, 2002; Carlander, 1977). These relatively high values also indicate rapid growth in bass.

\section{Hepatosomatic Index (HSI)}

Liver weights were not obtained for any fish from Station 63. Statistical analysis indicated that HSI in bass did not differ significantly among stations or between genders (Table 17). Nevertheless, because of the role of the liver in vitellogenesis and hormone homeostasis, HSI data are presented separately for males and females to facilitate comparisons with other endpoints (Fig. 14). The basin-wide mean HSI for female bass (all largemouth) was 1.0\%. Station means ranged from $0.9 \%$ (Station 16) to $1.1 \%$ (Station 514). Most individual values were between 0.6 and $1.5 \%$; only one fish from each of Stations 513 and 514 were $>1.5 \%$ (Fig. 14). All individual values were within the range reported for female bass in previous and ongoing studies (BEST Program, unpublished data from the Columbia River Basin; Blazer and others, 2002).

The overall mean HSI for male bass was similar to that for females $(0.9 \%)$. Station means ranged from $0.7 \%$ (Station 16) to $1.0 \%$ (Stations 512, 513, 514), and most individual values were between $0.6 \%$ and $1.4 \%$; only one fish (Station 513, 2.3\%) exceeded $1.4 \%$ (Fig. 14). The livers of male bass from Station 16 were comparatively small (Fig. 14). As was true for female bass, the range of individual values was similar to that reported for male bass collected in previous and concurrent studies (Blazer and others, 2002), indicating that values $<1.0 \%$ are not abnormal for bass. In addition, and in contrast to findings for sites in the MRB (Blazer and others, 2002), at no station were HSI values in RGB bass indicative of liver enlargement characteristic of chronic chemical exposure. 
Table 20. Distribution of Health Assessment Index (HAl) scores in carp and bass (Micropterus sp.) from the Rio Grande Basin, by station. See Table 1 for station locations and collection dates.

\begin{tabular}{|c|c|c|c|c|c|c|c|c|c|c|c|c|c|}
\hline \multirow{3}{*}{ Taxon and station } & \multicolumn{12}{|c|}{ HAl score } & \multirow{3}{*}{$\begin{array}{c}\text { Tota } \\
n\end{array}$} \\
\hline & \multicolumn{2}{|c|}{0} & \multicolumn{2}{|c|}{$10-30$} & \multicolumn{2}{|c|}{$40-60$} & \multicolumn{2}{|c|}{$70-90$} & \multicolumn{2}{|c|}{$100-120$} & \multicolumn{2}{|c|}{130} & \\
\hline & $n$ & $\%$ & $n$ & $\%$ & $n$ & $\%$ & $n$ & $\%$ & $n$ & $\%$ & $n$ & $\%$ & \\
\hline \multicolumn{14}{|l|}{ Bass } \\
\hline 16 & 3 & 14 & 4 & 19 & 6 & 29 & 6 & 29 & 2 & 10 & 0 & 0 & 21 \\
\hline 63 & 0 & 0 & 0 & 0 & 5 & 63 & 1 & 13 & 1 & 13 & 1 & 13 & 8 \\
\hline 512 & 0 & 0 & 11 & 69 & 4 & 25 & 1 & 6 & 0 & 0 & 0 & 0 & 16 \\
\hline 513 & 2 & 9 & 6 & 27 & 9 & 41 & 2 & 9 & 2 & 9 & 1 & 5 & 22 \\
\hline 514 & 0 & 0 & 0 & 0 & 4 & 50 & 3 & 38 & 0 & 0 & 1 & 13 & 8 \\
\hline \multicolumn{14}{|l|}{ Carp } \\
\hline 16 & 1 & 5 & 2 & 10 & 12 & 60 & 5 & 25 & 0 & 0 & 0 & 0 & 20 \\
\hline 63 & 1 & 4 & 7 & 28 & 10 & 40 & 4 & 16 & 3 & 12 & 0 & 0 & 25 \\
\hline 64 & 4 & 10 & 18 & 45 & 11 & 28 & 7 & 18 & 0 & 0 & 0 & 0 & 40 \\
\hline 65 & 1 & 5 & 8 & 40 & 11 & 55 & 0 & 0 & 0 & 0 & 0 & 0 & 20 \\
\hline 511 & 0 & 0 & 1 & 5 & 10 & 50 & 5 & 25 & 4 & 20 & 0 & 0 & 20 \\
\hline 512 & 0 & 0 & 5 & 36 & 5 & 36 & 3 & 21 & 1 & 7 & 0 & 0 & 14 \\
\hline 513 & 0 & 0 & 5 & 25 & 9 & 45 & 4 & 20 & 1 & 5 & 1 & 5 & 20 \\
\hline 514 & 2 & 10 & 6 & 30 & 7 & 35 & 3 & 15 & 1 & 5 & 1 & 5 & 20 \\
\hline 515 & 0 & 0 & 1 & 10 & 4 & 40 & 1 & 10 & 3 & 30 & 1 & 10 & 10 \\
\hline 516 & 0 & 0 & 8 & 44 & 2 & 11 & 7 & 39 & 1 & 6 & 0 & 0 & 18 \\
\hline \multicolumn{14}{|l|}{ Totals } \\
\hline Bass & 5 & 7 & 21 & 28 & 28 & 37 & 13 & 17 & 5 & 7 & 3 & 4 & 75 \\
\hline Carp & 9 & 4 & 61 & 29 & 81 & 39 & 39 & 19 & 14 & 7 & 3 & 1 & 207 \\
\hline Bass and carp & 14 & 5 & 82 & 29 & 109 & 39 & 52 & 18 & 19 & 7 & 6 & 2 & 282 \\
\hline
\end{tabular}

Many of our HSI values for bass and most of those from the MRB (Blazer and others, 2002) were lower than the average relative liver weight for resting fish (1-2\%) suggested by Gingerich (1982). They were also smaller than the values reported for male and female largemouth bass (treatments and controls) exposed in Florida to paper mill effluents (Sepúlveda and others, 2001; 2003). However, the Florida fish were sampled in the spring, during the reproductive season, when liver enlargement is normal. In addition, the formula used to compute the HSI for the Florida fish differed slightly from that used for the RGB and MRB fish.

\section{Splenosomatic Index (SSI)}

An ANOVA model that included station, sex, and the interaction of these factors was statistically significant and explained 31\% of SSI variation in carp (Table 17). Differences between genders and among stations were statistically significant (Table 17); mean SSI was lower (that is, spleen size was smaller) in females than in males. In bass, the ANOVA model was marginally significant $(P=0.07)$ and accounted for only $19 \%$ of the variation, but there was some evidence supporting among-station differences (Table 17). The biological reason for differences between genders is not known, but similar findings were reported for carp collected from the
MRB in 1995 (Blazer and others, 2002) and from the CRB in 1997 (BEST Program, unpublished data from the Columbia River Basin).

The basin-wide mean for SSI in male carp was $0.28 \%$. Station means ranged from 0.15 (Station 515) to $0.44 \%$ (Station 516), and most values (90\%) were between 0.08 and $0.49 \%$ (Fig. 15). The lowest values $(0.01 \%)$ occurred at Stations 512 and 515; all other SSI values in male carp were $\geq 0.08 \%$ (Fig. 15). Individual male carp with SSI values $>0.5 \%$ were captured at Stations 64, 514, and 516 (Fig. 15). The maximum SSI value in male carp $(1.5 \%)$ occurred at Station 64, but all other values for this station were within the range of other stations. In female carp the basin-wide mean for SSI was $0.20 \%$. Station means ranged from $0.13 \%$ at Station 512 to $0.28 \%$ at Station 514, and $90 \%$ of the individual values were between 0.08 and $0.32 \%$ (Fig. 15). Similar to male carp, very low values $(0.01 \%)$ characterized one female carp from each of Stations 512 and 515 and the maximum value $(0.80 \%)$ was obtained from Station 64 (Fig. 15). Values $>0.4 \%$ also occurred at Stations 16 and 514, and most female carp from Stations 514 and 516 had SSIs $>0.2 \%$. (Fig. 15). Therefore, and as also described for males, the means, medians and individual values were greatest at Stations 514 and 516 (Fig. 15).

Because SSI values in bass did not differ significantly between genders (Table 17) they were combined for analysis (Fig. 15); however, SSI values are tabulated by gender and age 

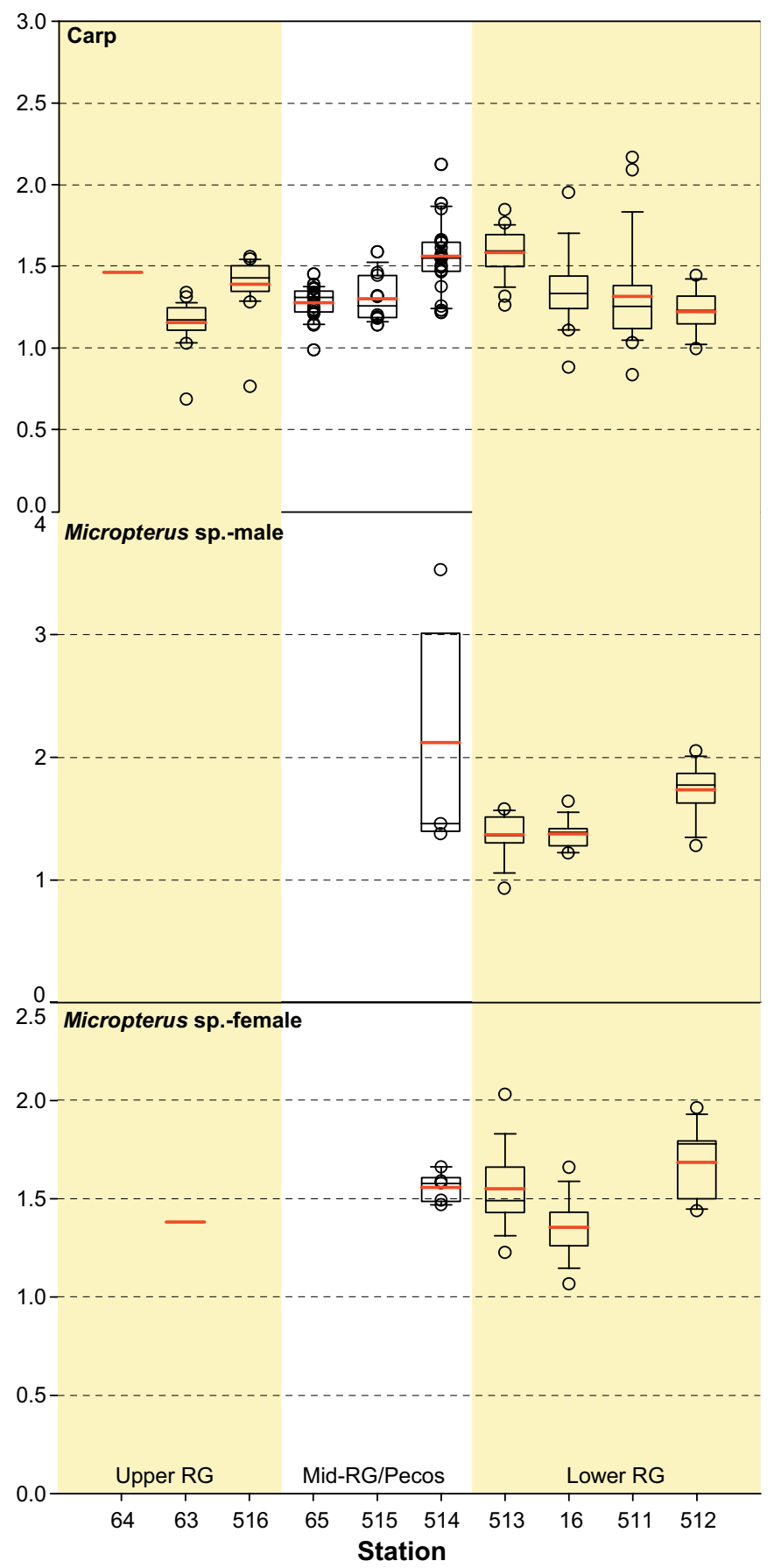

Figure 13. Condition factor (CF) of male and female carp and bass (Micropterus sp.), by station. Shown for each group are points representing individual fish and the mean (red horizontal line), median (black horizontal line), interquartile range (box), and the 10th and 90th percentiles (whiskers). Stations are ordered from upstream to downstream and are grouped by sub-basin. See Table 1 for station descriptions and collection dates.

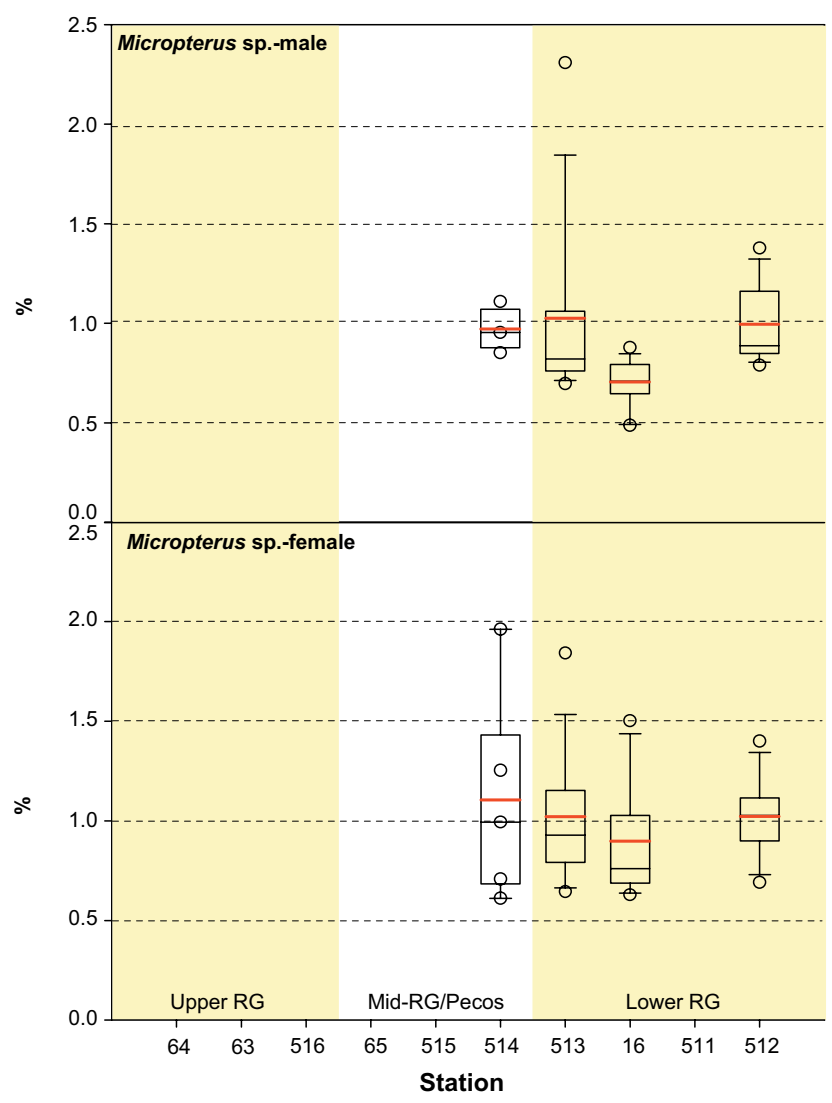

Figure 14. Hepatosomatic index (HSI) values of male and female bass (Micropterus sp.), by station. Shown for each group are points representing individual fish and the mean (red horizontal line), median (black horizontal line), interquartile range (box), and the 10th and 90th percentiles (whiskers). Stations are ordered from upstream to downstream and are grouped by sub-basin. See Table 1 for station descriptions and collection dates.

in Appendix Table 5. SSI in bass ranged from $<0.1 \%$ (many fish at Stations 16, 512, and 513) to 0.8\% (male largemouth bass from Station 16; Fig. 15; Appendix Table 5). The basinwide mean for SSI in bass was $0.11 \%$, with station means ranging from $0.07 \%$ at Station 512 to $0.22 \%$ at Station 514 (Fig. 15). All but four values were between 0.04 and $0.22 \%$ (Fig. 15); fish with unusually large spleens $(>0.35 \%)$ were obtained from Stations $16(n=1), 513(n=1)$, and $514(n=$ 2) (Fig. 15). Only at Station 514 were SSI values consistently high, however; this station had the highest median and the only mean $>0.12 \%$ (Fig. 15).

Overall, the range of SSI values in bass and carp from the RGB was similar to those observed in fish collected in 1995 from the MRB (Blazer and others, 2002), and the overall pattern was similar. That is, differences among stations were not clearly evident, but a few fish from a few sites had unusually large spleens relative to most others. 

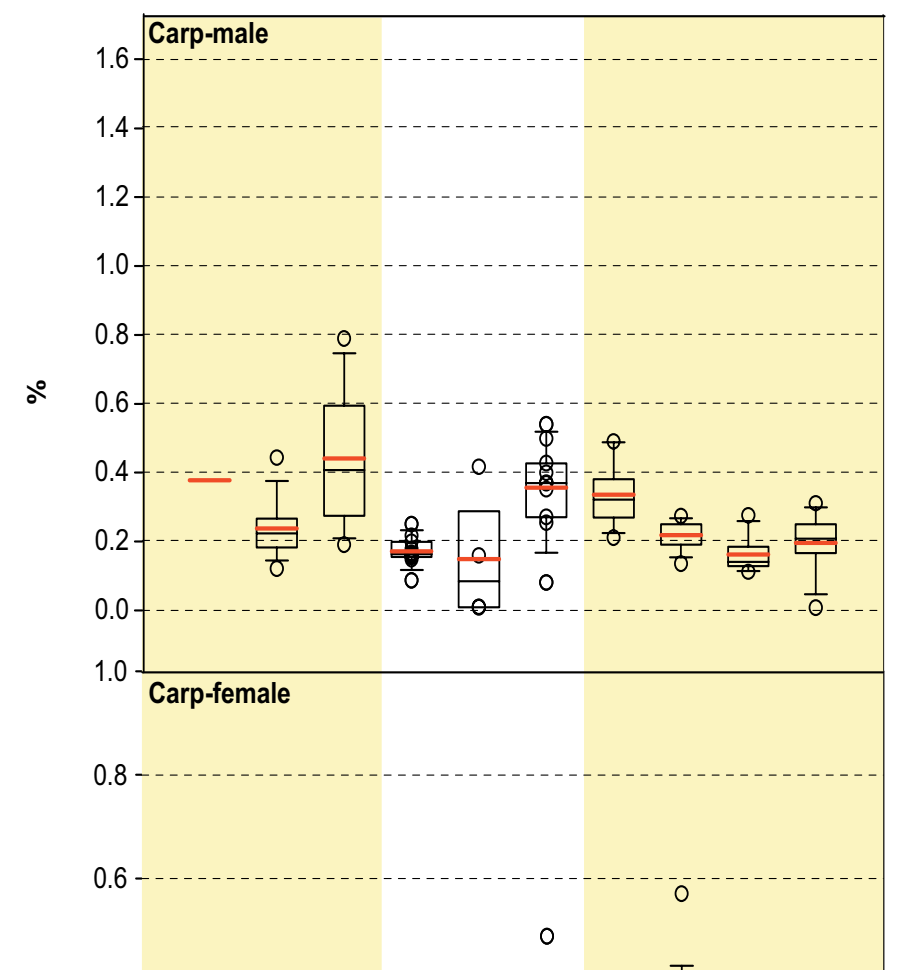

\&
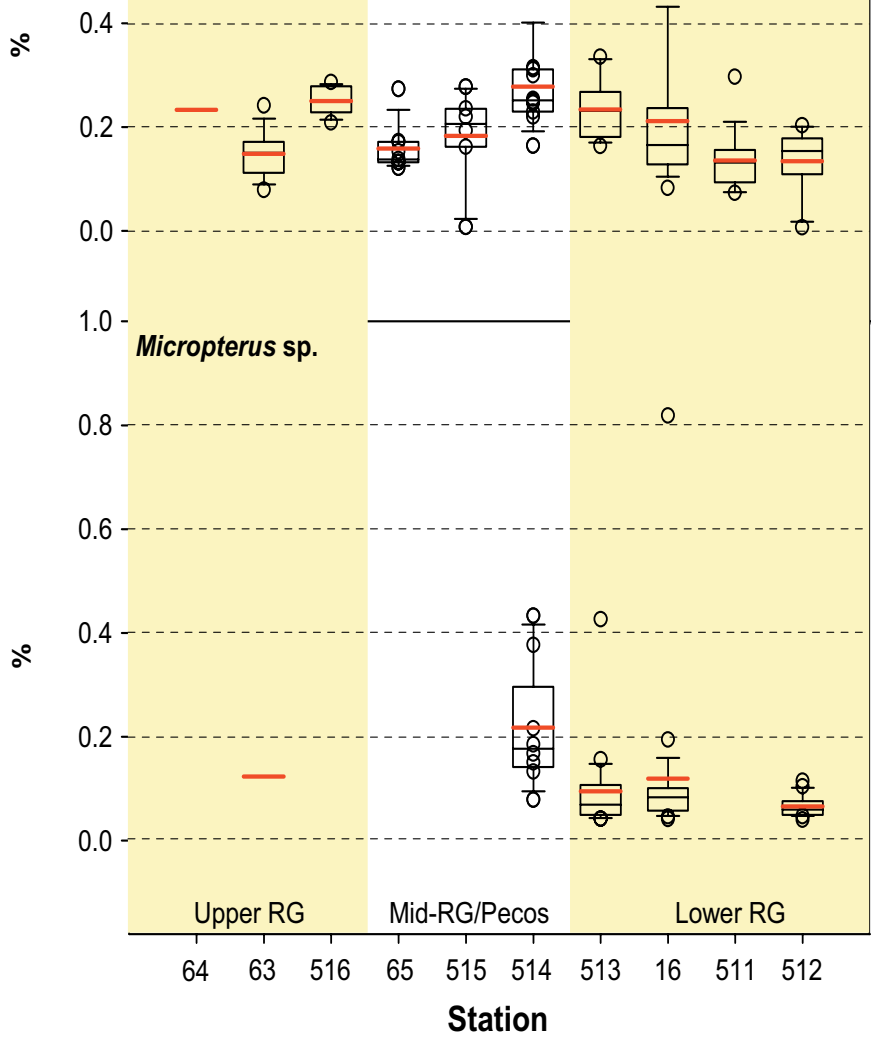

Figure 15. Splenosomatic index (SSI) values of male and female carp and bass (Micropterus sp.), by station. Shown for each group are points representing individual fish and the mean (red horizontal line), median (black horizontal line), interquartile range (box), and the 10th and 90th percentiles (whiskers). Stations are ordered from upstream to downstream and are grouped by subbasin. See Table 1 for station descriptions and collection dates.

\section{Cellular and Histopathological Indicators}

Splenic macrophage aggregates, as described and illustrated by Blazer and Dethloff (2000), were quantified and measured and are described in the following paragraphs. Gonadal tissue was examined microscopically. A high incidence of ovotestis in male bass from several sites, and ovarian pathologies including parasites and necrosis in carp and bass from others were observed. Ovotestis was described and illustrated by McDonald and others (2000).

\section{Macrophage Aggregates}

Three MA parameters [density or number of aggregates per $\mathrm{mm}^{2}$ (MAMM), mean size of aggregates (in $\mu \mathrm{m}^{2}$; MEANAREA), and percent of tissue occupied (TISSOC) by macrophage aggregates] were quantified in 199 carp and 75 bass. Statistical analysis indicated that different factors were significant for the three parameters (Table 17). In addition, data for MEANAREA and TISSOC required log-transformation prior to analysis due to heterogeneous variances. Results are nevertheless presented in the same format (combined genders for bass, separate for carp) for the three parameters. The MA parameters are summarized by station, gender, and age in Appendix Table 5. Station means adjusted to the basin-wide mean age of carp (3.2 y) and bass (1.8 y) are shown in Table 21.

\section{MAMM}

Preliminary ANOVA indicated that MAMM differed significantly among stations in carp, but no other factors or interactions were significant; however, several other factors approached significance, and the preliminary model explained $52 \%$ of the total variation (Table 17). The overall model was also significant for bass and accounted for $39 \%$ of total variation in MAMM (Table 17), and differences among stations approached statistical significance $(P=0.06)$. The evidence supporting an association with age was weak in both taxa, as also was the evidence supporting differences between genders (Table 17).

The basin-wide mean for MAMM in male carp was 8.8 $\mathrm{MA} / \mathrm{mm}^{2}$. Station means ranged from $4.0 \mathrm{MA} / \mathrm{mm}^{2}$ at Station 513 to $13.6 \mathrm{MA} / \mathrm{mm}^{2}$ at Station 512 (Fig. 16). Most values (90\%) were between 1.2 and $16.0 \mathrm{MA} / \mathrm{mm}^{2}$, but no MAs were detected in two male carp from Station 514. Overall, MAMM in male carp tended to be greatest at Stations 65 and 512 and lowest at Stations 513 and 514, but there was considerable variation within the stations such that only Station 512 differed noticeably (higher) than the others (Fig. 16). In female carp the basin-wide mean for MAMM was $7.8 \mathrm{MA} / \mathrm{mm}^{2}$. Station means ranged more widely in female than in male carp, from $1.8 \mathrm{MA} / \mathrm{mm}^{2}$ at Station 513 to $16.2 \mathrm{MA} / \mathrm{mm}^{2}$ at Station 512 (Fig. 16), but the range of individual values was similar. No MAs were detected in five female carp, from Stations $16(n=$ 1), $513(n=2)$, and 514 ( $n=2$; Fig. 16). Overall, MAMM in 


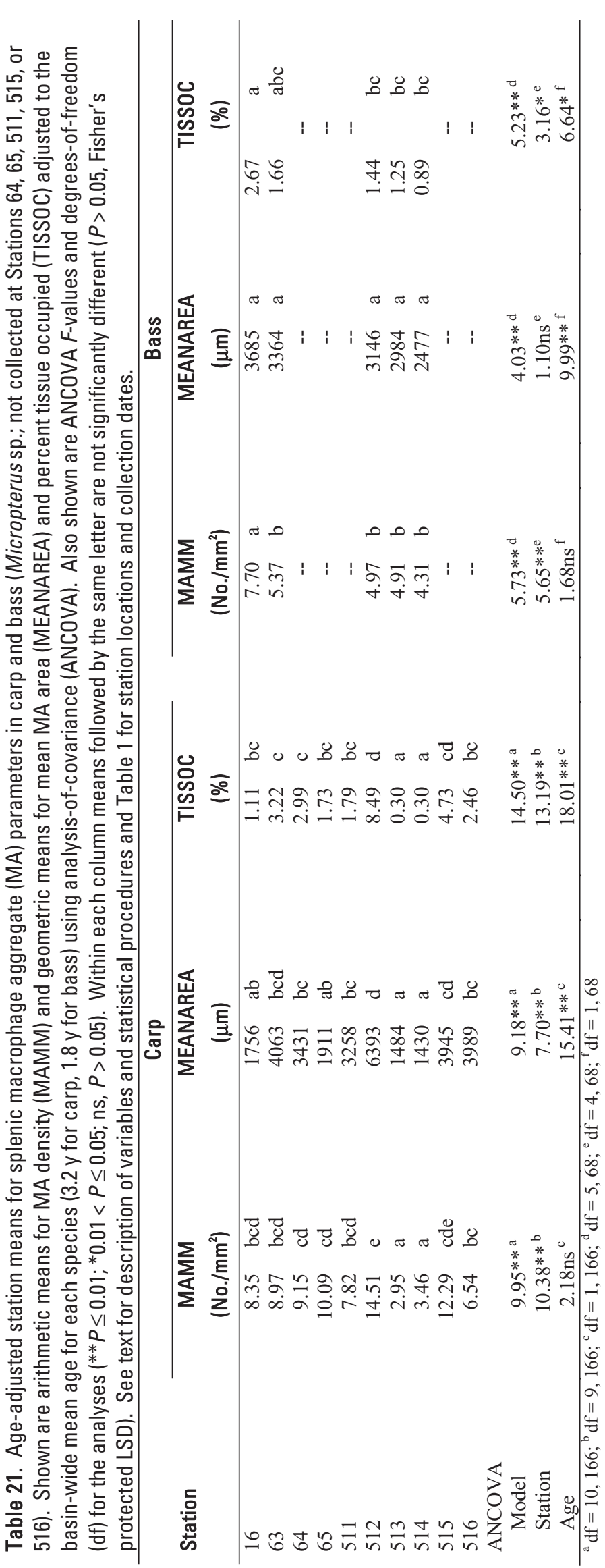

female carp was less variable than in males, and among-station differences were more evident. The overall pattern was the same; however, MAMM was generally lowest at Stations 513 and 514 and greatest at Station 512 (Fig. 16). Because the effect of age on MAMM was not significant, the age-adjusted station means (sexes combined) reflected the overall pattern of the unadjusted means for males and females. That is, stations from which carp contained the greatest MA densities (512 and 515) differed significantly from those with the smallest $(513,514)$, with considerable overlap among the other stations (Table 21). Overall, the range of MAMM values and station means in RGB carp was about the same as what was reported in carp collected from the MRB in 1995 (Blazer and others, 2002).

The basin-wide mean for MAMM in bass was 5.7 MA/ $\mathrm{mm}^{2}$. Station means were lowest at Station 514 (4.3 MA/ $\left.\mathrm{mm}^{2}\right)$ and highest at Station $16\left(7.8 \mathrm{MA} / \mathrm{mm}^{2}\right.$; Fig. 16), but the other three station means were similar $\left(4.8-5.7 \mathrm{MA} / \mathrm{mm}^{2}\right)$, and $90 \%$ of MAMM values were between 2.4 and $9.4 \mathrm{MA} / \mathrm{mm}^{2}$. MAs were present in all bass, but all MAMM values were $<12$ $\mathrm{MA} / \mathrm{mm}^{2}$. Eight of the 12 highest values were at Station 16 (Fig. 16). As was true for carp, the effect of age on MAMM in bass was not significant (Table 21) and the age-adjusted station means for bass are essentially the same as the unadjusted values (Fig. 16). MA density in bass from Station 16 was significantly greater than at all other stations from which bass were collected (Table 21). In addition, and in contrast to carp, the range of MAMM values in bass from the RGB was smaller than what was reported for MRB bass collected in 1995, where individual bass with MAMM values $>12 \mathrm{MA} / \mathrm{mm}^{2}$ were common and two station means exceeded $10 \mathrm{MA} / \mathrm{mm}^{2}$ (Blazer and others, 2002).

\section{MEANAREA}

In contrast to MAMM, preliminary statistical analysis indicated that age was weakly associated $(P=0.09)$ with log-transformed MEANAREA in carp, but not in bass (Table 17). ANOVA models that included terms for station, sex, age, station, and the interactions of these factors explained $57 \%$ of total MEANAREA variation in carp, but only $39 \%$ in bass (Table 17). Further analysis indicated that in bass, a 1-y increase in age was associated with a multiplicative change of $1.17(16 \%)$ in median MEANAREA. MEANAREA in carp differed significantly among stations after accounting for age whereas in bass only age was significant (Table 21).

Except for the two fish from Station 514 in which no MAs were observed (see MAMM), individual MEANAREA values in male carp ranged from $351 \mu \mathrm{m}^{2}$ at Station 65 to $14,709 \mu \mathrm{m}^{2}$ at Station 512 (Fig. 17). Ninety percent of the male carp examined had MEANAREA values of 600-8,500 $\mu \mathrm{m}^{2}$, but only four (one from Station 63 and four from Station 512) exceeded $8,000 \mu \mathrm{m}^{2}$. MEANAREA was $<6,000$ $\mu \mathrm{m}^{2}$ in all male carp from Stations 16, 65, 513, and 514 (Fig. 17). The basin-wide mean for MEANAREA in male carp 


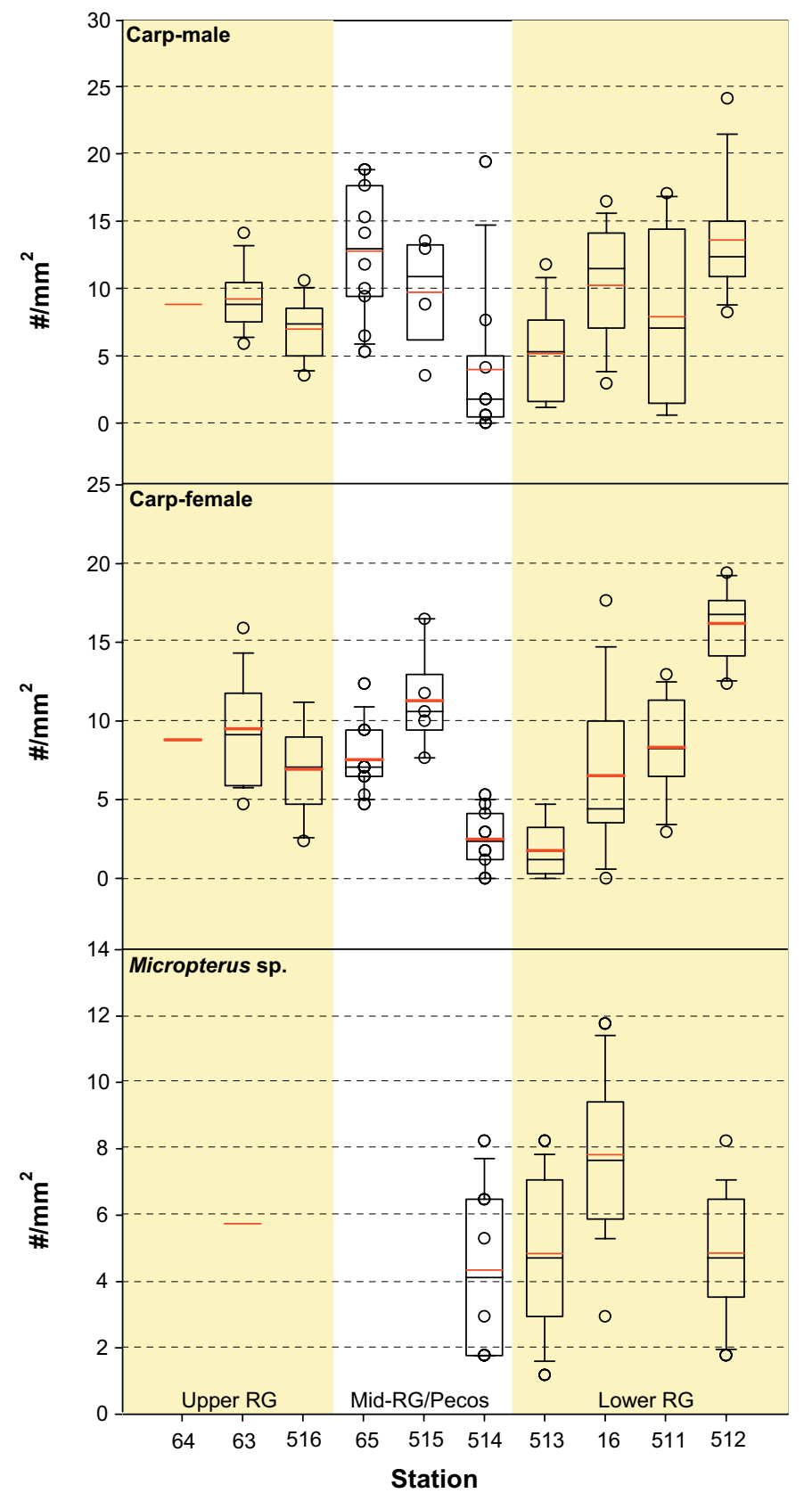

Figure 16. Splenic macrophage aggregate density (MAMM) in male and female carp and in bass (Micropterus sp.), by station. Shown for each group are points representing individual fish and the mean (red horizontal line), median (black horizontal line), interquartile range (box), and the 10th and 90th percentiles (whiskers). Stations are ordered from upstream to downstream and are grouped by sub-basin. See Table 1 for station descriptions and collection dates

was 3,319 $\mu \mathrm{m}^{2}$, with station means ranging from $1,453 \mu \mathrm{m}^{2}$ at Station 514 to 7,349 $\mu^{2}$ at Station 512 (Fig. 17). Overall, MEANAREA in male carp tended to be greatest at Station 512 and lowest at Stations 65 and 514. In female carp the range of MEANAREA values was similar to that of males. Except for the five fish from Stations 16, 513, and 514 in which no MAs

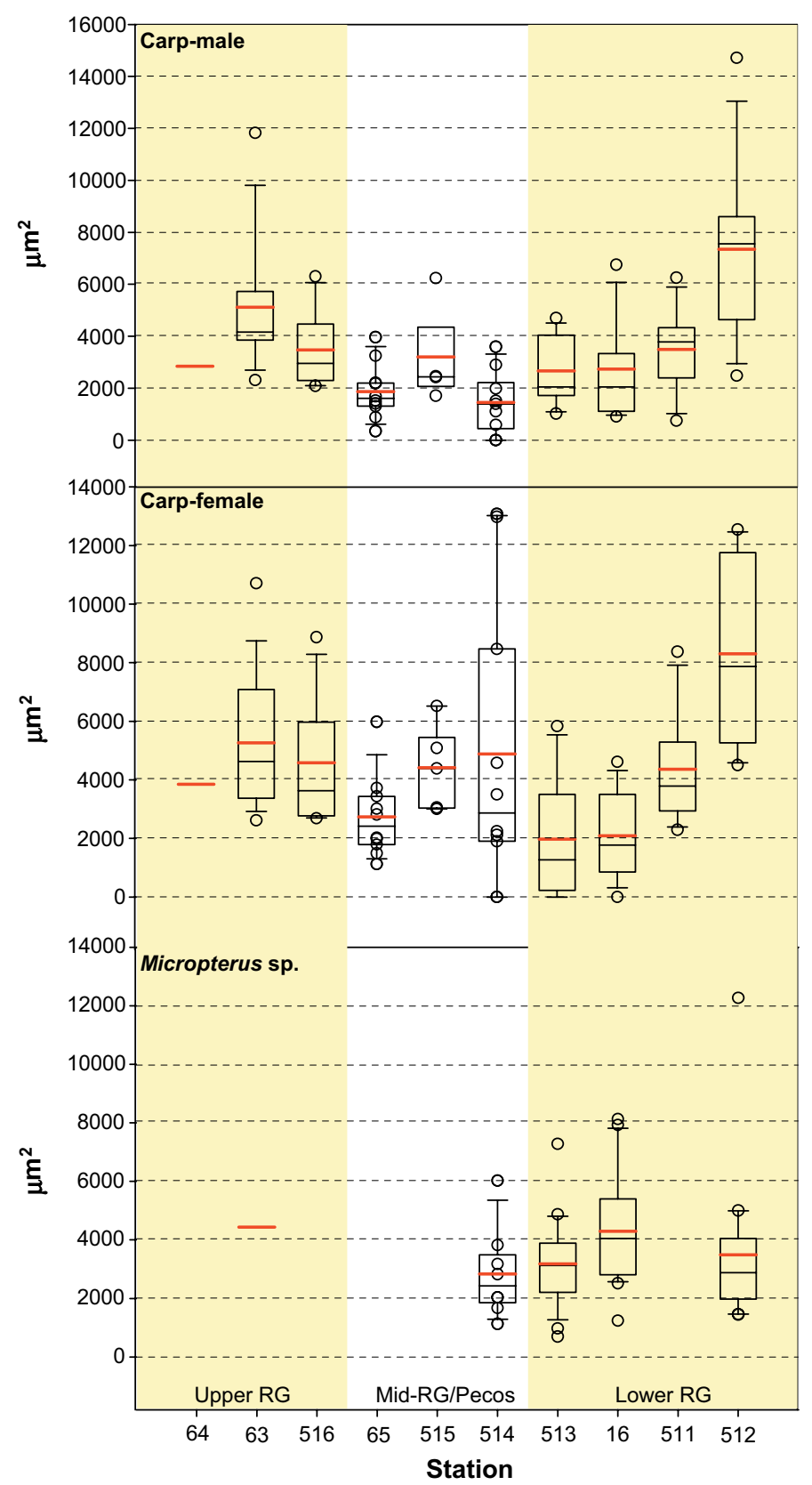

Figure 17. Splenic macrophage aggregate area (MEANAREA) in male and female carp and in bass (Micropterus sp.), by station. Shown for each group are points representing individual fish and the mean (red horizontal line), median (black horizontal line), interquartile range (box), and the 10th and 90th percentiles (whiskers). Stations are ordered from upstream to downstream and are grouped by sub-basin. See Table 1 for station descriptions and collection dates.

were observed (see MAMM), individual MEANAREA values ranged from $462 \mu \mathrm{m}^{2}$ at Station 513 to $12,972 \mu \mathrm{m}^{2}$ at Station 514 , and most of the values were between 600 and 8,000 $\mu \mathrm{m}^{2}$ (Fig. 17). More females than males had large values, however; MEANAREA in individual female carp from Stations 63 ( $n$ $=2), 64(n=1), 511(n=1), 512(n=3), 514(n=2)$ and 516 
$(n=1)$ were $>8,000 \mu \mathrm{m}^{2}$ (Fig. 17). The basin-wide mean for MEANAREA in female carp was also larger $\left(4,119 \mu \mathrm{m}^{2}\right)$, with station means ranging from $1246 \mu \mathrm{m}^{2}$ at Station 64 to 8,300 $\mu^{2}$ at Station 512 (Fig. 17). Overall, MEANAREA values tended to be smallest at Station 16 and 513 and greatest at Station 512 (Fig. 17).

The ANOVA model indicated that age was significant for MEANAREA in carp (Table 17), and age-adjusted values were computed (Table 21). Age-adjusted geometric station means for carp (sexes combined) ranged from 1,430 $\mu^{2}$ at Station 514 to $6,393 \mu \mathrm{m}^{2}$ at Station 512 and differed significantly (Table 21). As noted for MAMM, age-adjusted MEANAREA in carp was greatest at Station 512 and smallest at Stations 513 and 514, but the ordering of the intermediate stations differed. Differences among intermediate stations were not statistically significant, however (Table 21). In addition, and in contrast to MAMM, the range of MEANAREA values in carp was slightly greater in the RGB than what was reported for the MRB in 1995, but the station means were about the same (Blazer and others, 2002).

In bass, individual MEANAREA values ranged from $699 \mu \mathrm{m}^{2}$ at Station 513 to $12,262 \mu \mathrm{m}^{2}$ at Station 512 (Fig. 17). Ninety percent of the bass examined had MEANAREA values of 1,403-7,747 $\mu \mathrm{m}^{2}$. MEANAREA was $>6,000 \mu \mathrm{m}^{2}$ in nine bass representing all five stations, and three of these values were $>8,000 \mu \mathrm{m}^{2}$ (Fig. 17). Age-adjusted geometric station means (sexes combined) were between 2,477 and 3,685 $\mu \mathrm{m}^{2}$ for all stations and did not differ significantly (Table 21). Except for the one large value at Station 512, the distribution of MEANAREA in RGB bass was similar to what was reported for MRB bass collected in 1995 (Blazer and others, 2002).

\section{TISOCC}

Preliminary ANOVA models that included terms for station, gender, age, and the interactions of these factors were statistically significant and explained $61 \%$ of the total variation in log-transformed TISSOC in carp and $40 \%$ in bass (Table 17). After accounting for all other factors in the model, this analysis indicated that differences among stations were significant in carp, and that the effect of age was marginally significant $(P=0.09)$. In contrast, neither factor was significant in bass despite the fact that the overall model was significant (Table 17). Further analysis with the genders combined indicated a positive association between age and TISOCC in both taxa, however, and differences among stations were statistically significant after accounting for age (Table 21). A 1-y increase in age was associated with a multiplicative change of $1.23(23 \%)$ in median TISOCC. In bass, a 1-y increase in age was associated with a multiplicative change of $1.25(24 \%)$ in median TISOCC.

In male carp, with the exception of the two fish from Station 514 in which no MAs were observed (see MAMM), individual TISSOC values ranged from $0.04 \%$ at Station 514

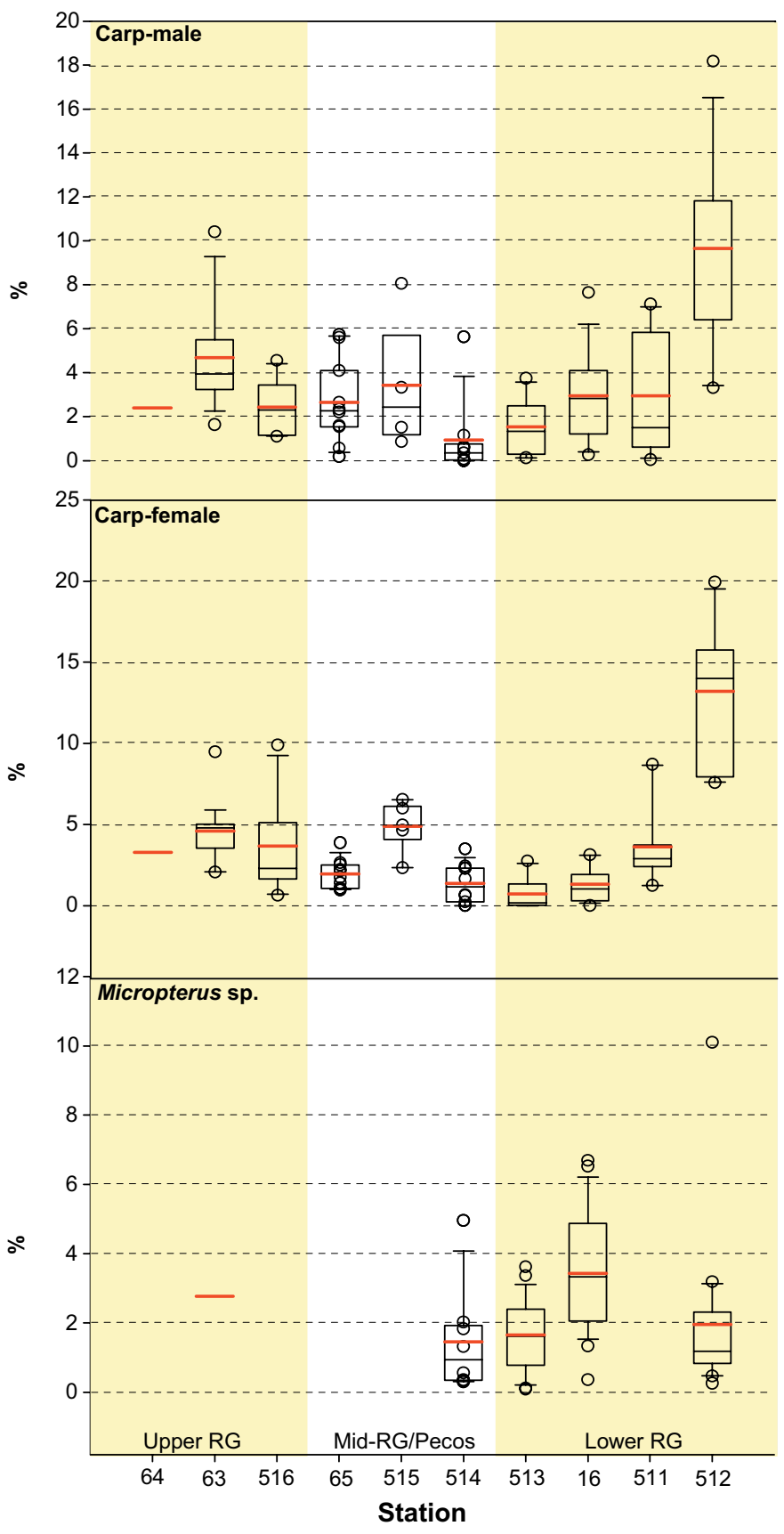

Figure 18. Percentage of splenic tissue occupied by macrophage aggregates (TISSOC) in male and female carp and in bass (Micropterus sp.), by station. Shown for each group are points representing individual fish and the mean (red horizontal line), median (black horizontal line), interquartile range (box), and the 10th and 90th percentiles (whiskers). Stations are ordered from upstream to downstream and are grouped by sub-basin. See Table 1 for station descriptions and collection dates.

to $18.2 \%$ at Station 512 (Fig. 18). Most values (90\%) were between 0.06 and $9.5 \%$. Seven male carp had TISOCC values $>10 \%$; of these, all but one were from Station 512 (Fig. 18). In contrast, TISSOC was $<4 \%$ in all male carp from Station 513 (Fig. 18, TISSOC). The basin-wide mean for TISSOC in 
male carp was $3.2 \%$, with station means ranging from $0.9 \%$ at Station 514 to $9.7 \%$ at Station 512 (Fig. 18). Overall, the pattern was similar to the other MA parameters in male carp, tending to be lowest at Stations 513 and 514 and greatest at Station 512 (Fig. 18). TISSOC in female carp were similar to that in males, but were less variable. Except for the five fish from Stations 16, 513, and 514 in which no MAs were observed (see MAMM), individual TISSOC values in female carp ranged from $<0.1 \%$ at Station 513 to $20.0 \%$ at Station 512 (Fig. 18). As was also true for the males, most values were between 0.6 and $9.5 \%$; however, only fish from Station 512 exceeded 10\% (Fig. 18). The basin-wide mean for TISSOC in female carp was $3.5 \%$, station means ranged from $0.7 \%$ at Station 513 to $13.3 \%$ at Station 512, and the overall pattern was similar to that observed in males (Fig. 18).

Because the ANOVA model indicated that age was also significant for TISSOC in carp (Table 17), age-adjusted geometric station means were computed (Table 21). Ageadjusted TISOCC means (genders combined) for carp ranged from $<1 \%$ at Stations 513 and 514 to $8.49 \%$ at Station 512 (Table 21). As was true for the other MA parameters, the largest station means differed significantly from the smallest, but there was considerable overlap among the intermediate values (Table 21). Most TISSOC values in RGB carp were similar to those reported for MRB carp (Blazer and others, 2002) with the notable exception of Station 512, where TISSOC in carp (raw data and age-adjusted) was the greatest observed in either basin.

Individual TISOCC values in bass ranged from $0.08 \%$ at Station 513 to $10.1 \%$ at Station 512 (Fig. 18). Most values (90\%) were between 0.25 and $5.5 \%$. TISOCC was $>5 \%$ in a total of eight bass from three stations $(16,63,512)$. In contrast, all but two values from Stations 512, 513, and 514 were $<3.6 \%$. Except for one fish with a large value (noted previously), and in contrast to carp, TISSOC values were generally low in bass from Station 512 (Fig. 18). The basinwide mean for TISSOC in bass was $2.3 \%$, with station means ranging from $1.5 \%$ at Station 514 to $3.4 \%$ at Station 16 (Fig. 18). Age-adjusted mean TISOCC (sexes combined) was 0.89 $1.66 \%$ at Stations $63,512,513$, and 514 but was $2.67 \%$ at Station 16; the latter differed significantly from all others (Table 21). Overall, and also in contrast to results for carp, TISSOC in bass was within the range of values reported for bass from the MRB (Blazer and others, 2002).

\section{Fish Health Indicators: Summary}

A high incidence of confirmed tumors or other grossly visible indications that fish were exposed to high concentrations of toxic chemicals were not observed at any RGB sites. Similarly, histopathological analyses revealed chemicallyinduced microscopic alterations in only a few fish. Of the quantitative fish health biomarkers, CF, HSI, and HAI have been the most widely used and discussed in the literature. CFs of 1.0-2.0 for carp and bass, the range of most values in the RGB, are typical for these taxa (Blazer and others, 2002; Carlander, 1977; 1969). Liver enlargement has been reported in largemouth bass from contaminated sites (Adams and McLean, 1985) as well as in other fishes exposed to contaminants in both field and laboratory studies (see review by Dethloff and Schmitt, 2000). Most male and female bass collected from the MRB in 1995 had liver weights representing $0.5-1.5 \%$ of body weight, but enlarged livers were detected in bass from a few contaminated sites (Blazer and others, 2002). According to Gingerich (1982), the liver constitutes 1-2\% of body weight in most fishes. Most RGB bass had proportionally smaller livers, as did most bass collected from the MRB in 1995 (Blazer and others, 2002).

Background information on external lesions, MA parameters, and SSI are either not completely relevant because studies conducted to date investigated only marine or estuarine fish or because information is not available. For external abnormalities, difficulties in comparing results among studies arise from probable systematic error caused by increasing familiarity of field personnel as the study progresses (Leonard and Orth, 1986) and from differences in the anomalies characterized and recorded (Fournie and others, 1996; Karr, 1981; Sanders and others, 1999). We used criteria modified only slightly from the $1995 \mathrm{MRB}$ investigation (Blazer and others, 2002), so the results of these surveys are comparable. In general, we noted sites at which $\geq 50 \%$ of carp, bass, or all fish had lesions, particularly if both carp and bass exceeded 50\%. For MA parameters a USEPA study conducted in the Gulf of Mexico established a value of $>40$ splenic MAs $/ \mathrm{mm}^{2}$ in at least one fish as a threshold for possible effects of hypoxia or sediment contamination (Fournie and others, 2001). Although Blazer and others (2002) used it as a benchmark for carp and bass in the MRB, this value was derived for estuarine fishes and it is important to note that additional research on freshwater fishes, particularly bass and carp, is necessary to determine a threshold for possible effects. Regardless, it is also important to note that using only MA numbers does not take into consideration that there can be a few very large aggregates.

In the RGB, mean CF and SSI in carp were greatest at Stations 513 and 514, and individual carp with relatively high CFs were captured Stations 16, 64, 511, and 514 (Figs. 13 and 15). Spleen size was also relatively large in individual carp from Station 16, 64, 514, and 516 (Fig. 15). In bass, mean SSI was also relatively high at Station 514, and individual fish with relatively large spleens were captured from Stations 16, 513 and 514 (Figs. 14 and 15). Enlarged spleen size is often associated with infections. In contrast, both carp and bass from Station 512 had relatively small spleens (Fig. 15), a condition that has been associated with exposure to contaminants (Blazer and others, 2002). At no stations were HSI values in bass indicative of liver enlargement associated with chronic exposure to chemical contaminants [See review by (Blazer and Dethloff, 2000) and subsequent studies by Sepúlveda and others $(2001 ; 2003)]$. This finding is in contrast to the enlarged 
livers in bass reported for contaminated MRB sites sampled in 1995 (Blazer and others, 2002).

The HAI had not been used with carp prior to the 1995 study (Blazer and others, 2002); however, it was used to assess largemouth bass populations in Tennessee Valley Authority reservoirs (Adams and others, 1993) and in the Catawba River system (Coughlan and others, 1996). In these studies, a positive linear relation between average fish weight or age and HAI score was noted, and Coughlan and others (1996) suggested that only bass of $250-450 \mathrm{~mm}$ (TL) be included in comparisons. Approximately $90 \%$ of the bass collected in the RGB met these criteria. Based on previous studies (Adams and others, 1993; Coughlan and others, 1996) and conservative precedent (Blazer and others, 2002), we assumed that mean HAI values $\leq 20$ were indicative of un-impacted or minimally impacted sites, whereas values $>50$ indicated intermediate sites and those $>70$ indicated a heavily impacted area. These values were used to characterize both carp and bass from the MRB as well as those from the RGB. Carp and bass from many MRB sites sampled in 1995 averaged $>70$, and most station means were $>50$ (Blazer and others, 2002). In the RGB, HAI scores were similar; the mean for carp from Station 515 was 70, and the means for Stations 511, 513, and 516 were $>50$ (Fig. 12). The mean for bass from Station 63 was also 70, and those from Stations 16, 513, and 514 were $>50$ (Fig. 12).

It is also important to note the "causes" of abnormal HAI ratings, as determined by histopathological analysis. In bass, abnormal ratings in fish from Station 63 were primarily due to frayed or marginate gills and abnormal livers. The latter were all due to the presence of helminth parasites. At Station 16 , most bass gills were normal and the bulk of the abnormal ratings resulted from internal nodules, focal discolorations, or spots on the liver, kidney, and spleen. Histologically it was determined these were parasitic lesions. At Station 513 many of the bass kidneys were rated in the field as urolithic. However, histologically no calcifications were noted and these lesions were also determined to be parasite-induced. Overall, most microscopic lesions in bass were diagnosed as inflammatory and often occurred in association with parasites. A high HAI rating for carp from Station 515 was primarily due to external lesions; the only abnormal internal ratings were for tan livers. At Stations 511, 513, and 516 many of the abnormal ratings were also due to tan livers. Histologically, the tan livers were found to contain hepatocytes with increased vacuolization, and ceroid/lipofuscin deposits were often contained within or replacing hepatocytes (Fig. 19). In addition, in many of the carp from these stations ceroid-containing cells were present within blood vessel walls (Fig. 19). These lesions could represent oxidative damage resulting from contaminant exposure. Four of 14 carp from Station 512 had abnormal kidneys rated as granular. In these four fish (and in one not identified as granular in the field), and in contrast to the bass described previously, urolithiasis or nephrocalcinosis (Fig. 19) was noted histologically in five of 14 carp.

No fish from the RGB contained $>40$ splenic MAs $/ \mathrm{mm}^{2}$ (MAMM), the criterion suggested by Fournie and others
(1996) as indicative of exposure of marine and estuarine fish to sediment contaminants or hypoxia. Moreover, all carp except one from Station 512 contained $<20 \mathrm{MA} / \mathrm{mm}^{2}$ and all bass had $<12 \mathrm{MA} / \mathrm{mm}^{2}$ (Fig. 12). These relatively low values were generally about the same as what was reported for carp and bass collected from the MRB in 1995 (Blazer and others, 2002). The distributions of the MA parameters in carp (age-adjusted as necessary) from all RGB stations sampled overlapped, but all three differed significantly among stations even after accounting for age effects (Table 17). Although low relative to the $40 \mathrm{MA} / \mathrm{mm}^{2}$ criterion of Fournie and others (1996), values of MAMM and the other MA parameters tended to be lowest at Stations 513 and 514 and greatest at Station 512 (Figs. 16-18; Table 21). In addition, the TISSOC values for carp from Station 512 exceeded those for any other station sampled in either the RGB or the MRB (Blazer and others, 2002). As a group, differences among stations were less evident for bass (Table 17); nevertheless, values of all MA parameters in bass were also relatively low at Station 514 and high at Station 16. Although MA values in bass from Station 512 were generally low, the greatest individual MEANAREA and TISSOC values for bass also occurred at Station 512 (Figs. 17 and 18). Increased numbers of MAs have been associated with exposure of fish to crude oil and to As [see review by (Blazer and Dethloff, 2000)]. In contrast to our findings, Mora and others (2001) reported that fish of several species obtained from resacas along the lower RG contained high numbers of MAs. It is important to note that their sample numbers were small and their fish were not aged, which makes direct comparisons with the 1997 data problematic.

In addition to the anomalies and parameters that we quantified, we attempted to identify other lesions as they became apparent during the histopathological examination of the various tissues. Among these was an apparent gradient in the proliferation of thyroid follicles within the kidney of carp that was not evident during gross examination. Fish from Stations 63, 64 and 516 contained very few thyroid follicles and those that were present tended to be small (Fig. 20). Greater numbers and larger size characterized the follicles in the kidneys of carp from Stations 65, 514 and 515 (Fig. 20). The kidneys of on carp from Station 514 contained a large area of abnormal-appearing thyroid follicles (Fig. 20). A greater number of even larger follicles were evident in carp from Stations 513, 512, 511 and 16 (Fig. 20). Similar observations were made for carp from the lower MRB (Blazer and others, 2002). As noted for the MRB, thyroid hyperplasia in fish and other organisms has been caused by exposure to contaminants and may represent a potential biomarker for contaminant effects on thyroid function. The effects of confounding factors such as area of kidney sampled, fish age, and so forth have not been evaluated, however. 

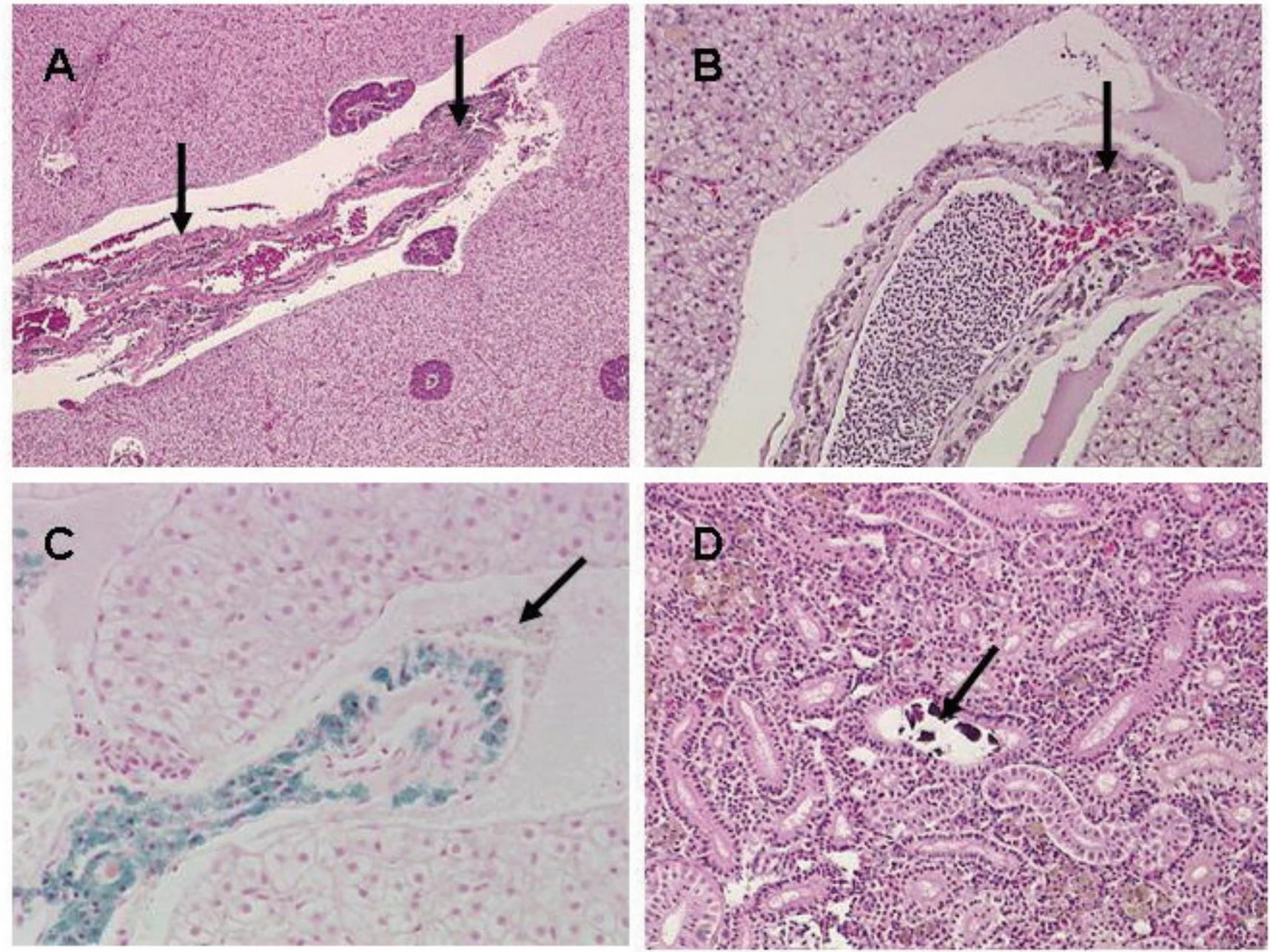

Figure 19. Microscopic pathology observed in carp from the Rio Grande Basin. A. Pigmented cell accumulations within the hepatic blood vessel walls (arrows) typical of carp from Stations 515, 511, 513 and 516. H \& E stain (X 165). B. Higher magnification (X 412) of A. C. The pigmented cells contained Perl's positive material, hemosiderin, which stained blue; and ceroid/lipofuscin pigment, which stained yellowish-brown (arrow). Perl's stain (X 824). D. Nephrocalcinosis or mineral deposition within tubules (arrow) was observed at Station 512. H \& E stain (X 412).

\section{Reproductive Biomarkers}

\section{Gonadal Histopathology}

\section{Gonadal Stage}

Ovary samples representing 113 female carp from all 10 stations were examined. Only gonadal stages 0 through 2 were present (Figs. 21 and 22). Stage 2 was predominant (81.5\% overall) and represented $64-100 \%$ of the female carp examined at most sites (Fig. 21). Only 17 fish (15\%) were in stage 1; these represented 33-62\% of the females at Stations 511, 512, and 513 (Fig. 21). Four female carp (3.5\%), all from Station 511, were in stage 0 . The distribution of stages in female carp differed slightly among the ten stations where they were collected (Fig. 21); at Stations 511, 512, and 513 they were less advanced (mostly stages 0 and 1 ) than at the other sites (mostly stages 1 and 2). These differences are probably related to sampling dates; although collections of fish from some stations occurred on multiple dates separated by several weeks, fish were collected at Station 511 in late September-early October 1997, 4-8 weeks before the other lower RGB sites (Table 1). Similarly, the stage-1 female carp from Station 512 were collected on the first sampling visit, in late October, whereas those collected in late November were all in stage 2. Conversely, female carp from Station 65, which were not collected until late January 1998, were in the same stage (all stage 3 ) as those from nearby stations collected months earlier (Fig. 22). Overall, the female carp from the RGB were generally in less advanced gonadal stages than those collected from the MRB in late 1995; in the MRB, 83\% of the female carp were in stage 3 , and stage- 3 females were predominant 

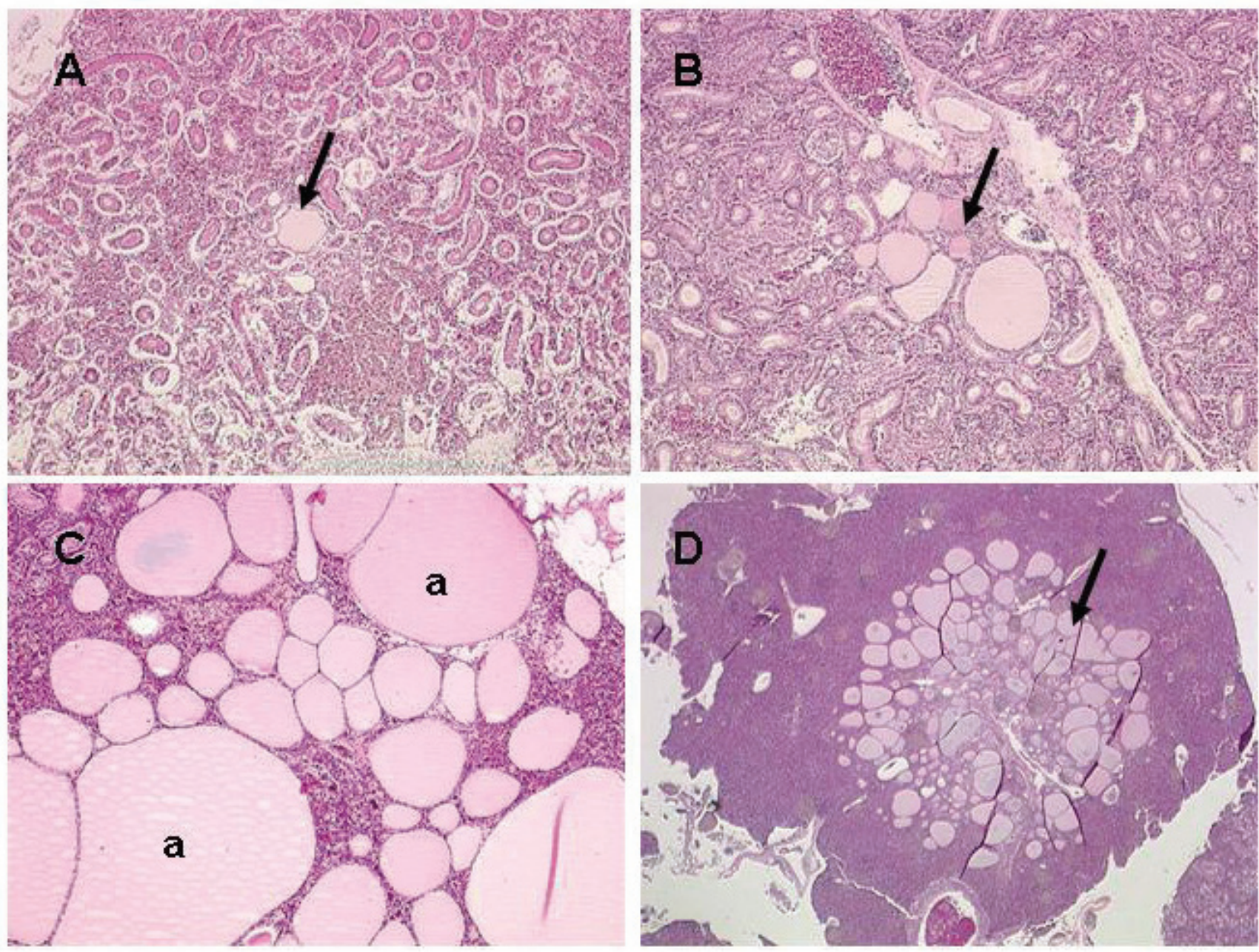

Figure 20. Thyroid follicles within the kidneys of carp from the Rio Grande Basin. A. Kidney tissue of a carp from Station 64 illustrating solitary (arrow) to small clusters of thyroid follicles commonly found in carp from the upper Rio Grande. H \& E stain (X 165). B. Kidney tissue of a carp from Station 514 illustrating larger accumulations (arrow), often of eight or more follicles, observed in the middle Rio Grande. H \& E stain (X 165). C. Kidney tissue of a carp from Station 513 illustrating accumulations of enlarged thyroid follicles (a) often observed in carp from the lower Rio Grande. H \& E stain (X 165). D. A nodule of abnormal thyroid tissue (arrow) in a carp from Station 515. H \& E stain (X 412).

at many sites, especially in the southern parts of the basin (McDonald and others, 2002). One 3-y old female carp from Station 64 could not be staged because no normal gonad tissue was observed; all follicles showed signs of degeneration, inflammation, and fibrosis (Fig. 23). This condition was not observed in other fish from Station 64, elsewhere in the RGB, or in previous studies with carp (Goodbred and others, 1997; Lee and others, 2000; McDonald and others, 2002).

Testes samples representing 92 male carp from all 10 stations were examined. Gonadal stages 0 through 3 were represented (Figs. 21 and 24). Most male carp were in more advanced gonadal stages than females; overall, 82 (89\%) were in stage 3. At all stations except Station 511, 75-100\% of the male carp examined were in stage 3 , and stage frequencies did not differ appreciably among these stations (Fig. 21). As noted for females, most male carp from Station 511 were also in less advanced gonadal stages (predominantly stage 2) than at the other stations (Fig. 21), which is consistent with the earlier collection date (Table 1). Stage- 2 males (few) were also obtained at Stations 16, 64, and 512, and one stage-1 male was collected at Station 16 (Fig. 21). The stage-2 male carp from Station 512 was collected in late October and was the only one obtained. All other male carp from Station 512, which were universally in stage 3, were collected in late November. As was true for female carp, male carp from Station 65, which were not collected until late January 1998, were in the same stage (all stage 2) as those from nearby stations that were sampled in late 1997 (Fig. 21). In contrast to female carp from the RGB, which were generally in earlier gonadal stages (1 and 2) than those collected from the MRB in 1995 (McDonald and others, 2002), male carp from all RGB sites except Station 511 were slightly more advanced (stage 3 ) than those from the 

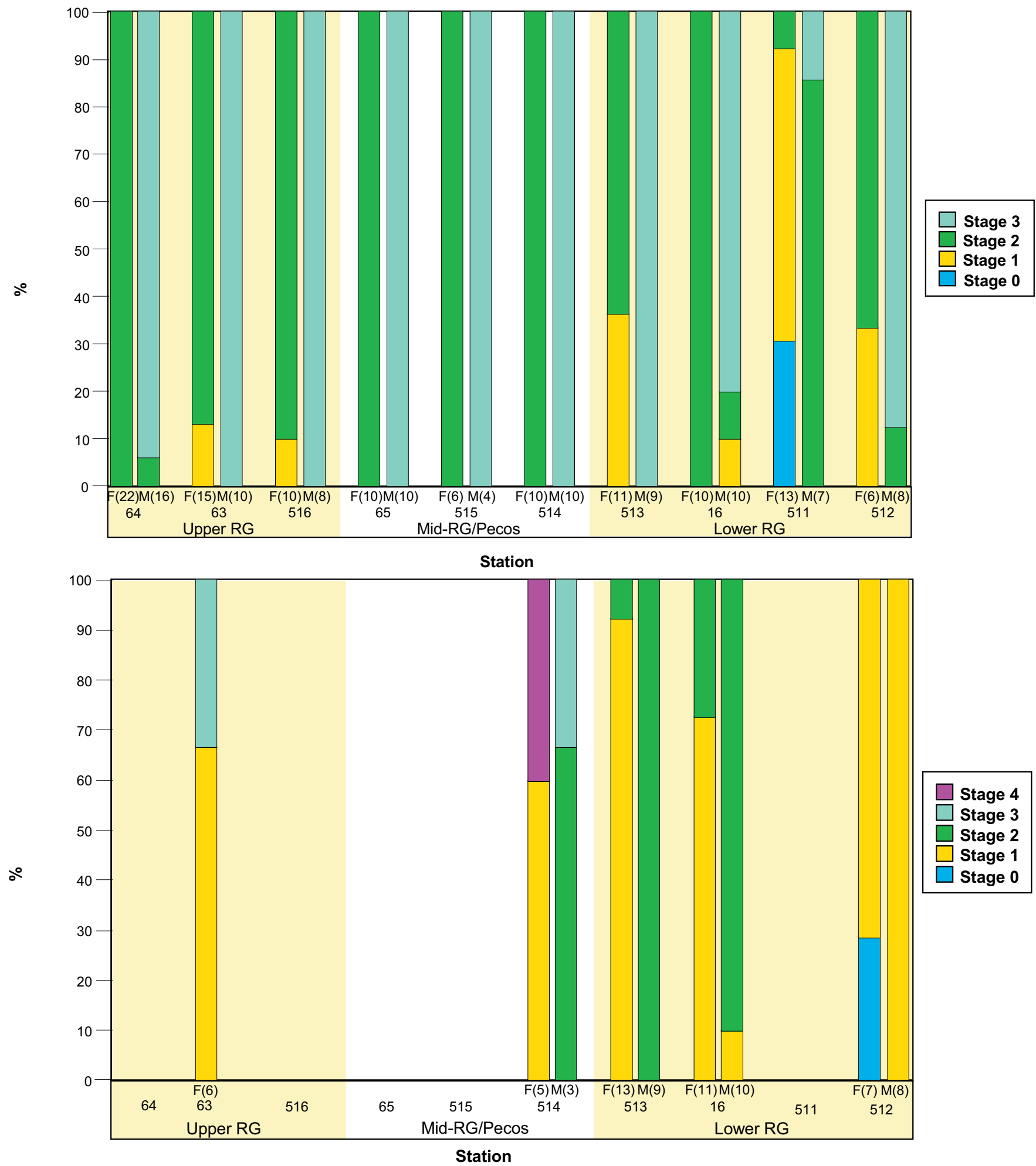

Figure 21. Gonadal stage of male and female carp (upper panel) and bass (lower panel), by station. Shown are the percentages ( $y$-axis) and total numbers (in parentheses) of fish in each stage. Stations are ordered from upstream to downstream and are grouped by subbasin. See Table 1 for station descriptions and collection dates. 

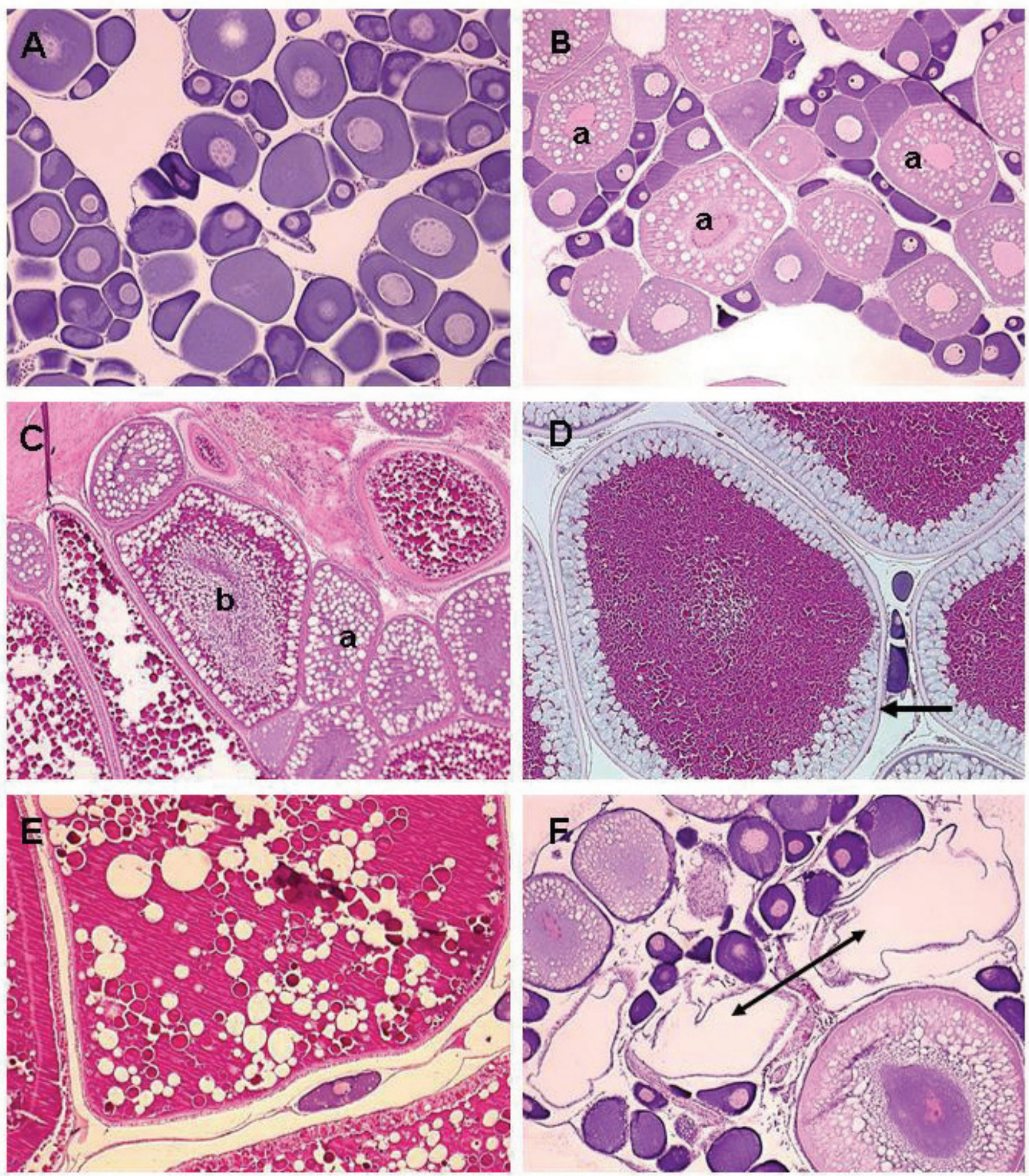

Figure 22. Gonadal stages in female carp and bass ovaries. A. Stage-0 (immature) ovary containing only previtellogenic oocytes. B. Stage-1 (early vitellogenic) ovary containing cortical alveolar oocytes (a) as well as previtellogenic stages. C. Stage-2 (mid-vitellogenic) ovary containing cortical alveolar (a) and more advanced oocytes (b) in which the yolk vacuoles are being pushed to the periphery and yolk globules are filling the central portion of the oocyte. D. Stage 3 (late vitellogenic) ovary in which most oocytes are enlarged, a thin layer of yolk vacuoles lines the periphery, yolk globules fill the cytoplasm, and the chorion (arrow) is thickened. E. Stage-4 (mature) ovary containing oocytes in which the yolk globules appear condensed. F. Stage-5 (spent) ovary (not encountered in fish from the Rio Grande Basin) containing post-ovulatory follicles (shown at the ends of the arrow). H \& E stain (X 165). 


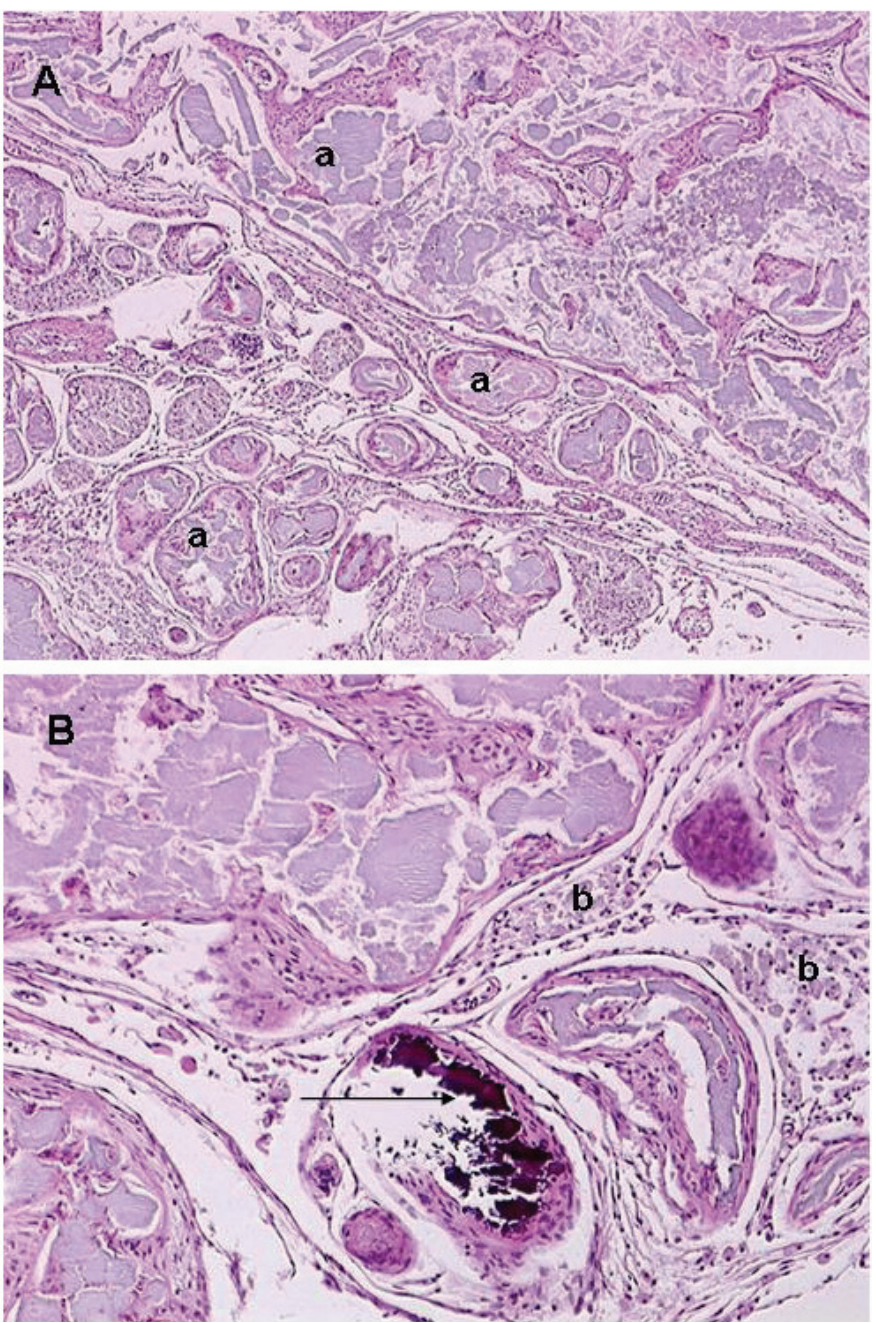

Figure 23. Ovarian section of a carp from Station 64. H \& E stain. A. Lower power (X 40) illustrating a lack of normal ovarian tissue. Follicles (a) are degenerate with remnants of yolk. B. At higher magnification (X 100) areas of calcification (arrow) and macrophage aggregates (b) are visible.

MRB, where $86 \%$ were in stages 1 and 2 .

Ovary samples representing 42 female bass from five stations $(16,63,512,513$, and 514) were examined. Of these, all were largemouth bass except for two smallmouth from Station 63. Gonadal stages 0-4 were represented (Figs. 21 and $22)$. Overall, $32(76 \%)$ were in stage 1 , four (10\%) were in stage 2 , and two (5\%) were in each of stages 0,3 , and 4 . Most (60-92\%) of the female bass at all stations sampled were in stage 1 (Fig. 21). Stage-0 (immature) female bass were collected only at Station 512; one was obtained in late October, the other when the site was re-sampled in late November. Stage-2 female bass were obtained from Stations 16 and 513, and stage-3 females were found only at Station 63 (Fig. 21); the latter were smallmouth bass. Two female bass collected at Station 514 in early November (Table 1) were in stage 4 (Fig. 21). The occurrence of stage-4 female largemouth bass in South Texas at this time of the year is unusual; in the fall of 1995, stage-4 female bass (all smallmouth) were found exclusively at two sites in the northernmost parts of the MRB (McDonald and others, 2002). The two fish from Station 514 were subsequently found to be harboring ovarian parasites (see atresia discussion in next section). In all other respects, the distribution of female bass among reproductive stages is similar to what was reported for female largemouth bass from stations in the southern parts of the MRB.

Testes samples representing 30 male bass from four stations $(16,512,513$, and 514) were examined; no male gonad samples were obtained at Station 63. All male bass examined were largemouth except for one smallmouth obtained from Station 514. Gonadal stages 1-3 were represented (Figs. 21 and 24). As was true for male carp, male bass were generally in more advanced gonadal stages than females. Overall, 20 $(67 \%)$ were in stage 2 , nine $(30 \%)$ were in stage 1 , and one (3\%) was in stage 3 (Fig. 21). As was true for female bass, the stage- 3 male was the smallmouth. Stage 2 male largemouth bass were obtained at Stations 16, 513, and 514 (Fig. 21). All male bass from Station 512 were in stage 1 as was one from Station 16 (Fig. 21). Overall, these results are also similar to what was reported for male largemouth bass from the MRB (McDonald and others, 2002).

\section{Atresia}

Statistical analysis indicated that neither age nor stage were significant contributors to atresia differences RGB carp or bass (Table 17). After accounting for these factors, differences among stations were also not significant in either taxon (Table 17). A model that included terms for station, stage, age, and the interactions of these factors was nevertheless statistically significant overall and accounted for $49 \%$ of the variation in carp (Table 17). Although no factors were strongly significant, the effect of age approached statistical significance $(P=0.11)$. In female bass the model was also statistically significant and accounted for $95 \%$ of the total variability. In addition, the interaction of station, age, and stage was significant, and one other term that included age approached significance $(P=0.11$; Table 17). Collectively, these results indicate a slight increase in atresia with fish age and gonadal stage, and the data are presented accordingly.

\section{Atresia in Carp}

Overall, atresia in carp tended to be greatest at stations in the lower RGB than in the upper (Fig. 25), but there was considerable variability and the effects of age and stage were confounded (Table 17). As expected, small percentages of atretic eggs were observed in stage- 0 female carp, which are immature. In four stage-0 fish from Station 511 the mean was $3.0 \%$; three had $0 \%$ and one had $12 \%$ (Appendix Table 6). For those in stages 1 and 2, the overall mean was $6.7 \%$ with values ranging from $0 \%$ to $25 \%$, but most of these fish also had no or few (0-15\%) atretic eggs (Appendix Table 6). Stage-1 and -2 fish from Station 65 contained relatively few atretic eggs 

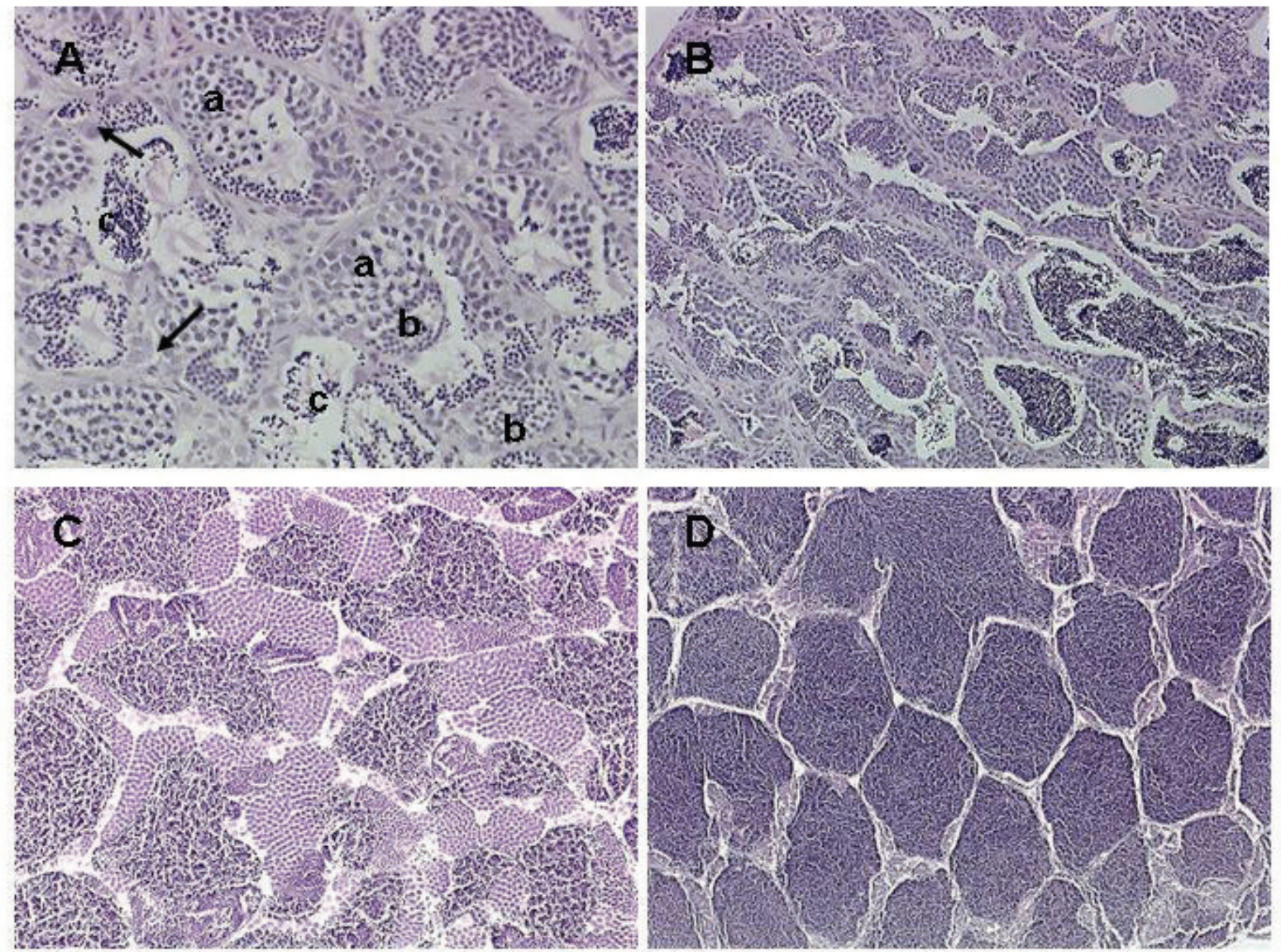

Figure 24. Gonadal stages in male carp and bass testes. A. Stage-1 (early spermatogenic) testes containing all stages of spermatogenesis; spermatogonia (arrows), spermatocytes (a), spermatids (b), and spermatozoa (c) may be observed. H \& E stain (X 824). B. Stage-1 testes in which spermatocytes and spermatids predominate. H \& E stain (X 412). C. Stage-2 (mid-spermatogenic) testes containing approximately equal numbers of spermatocytes, spermatids, and spermatozoa. H \& E stain (X 412). D. Stage-3 (late spermatogenic) testes containing primarily spermatozoa. H \& E stain (X 412).

(mean $=0.6 \%)$ whereas means for the other stations ranged from $4.0 \%$ at Station 64 to $>10 \%$ at Station 512 (Fig. 25; Appendix Table 6). Individual female carp with $>20 \%$ atretic eggs were obtained from Stations 16, 512, and 515 (Fig. 25). All three female carp collected at Station 512 on the first visit (late October, stages 1 and 2) had 15-25\% atresia whereas the three obtained in late November (stages 2 and 3) had only 3-6\% (Appendix Table 6). The low incidence of atresia at Station 65, a number of higher values $(>10 \%)$ at Station 511, and the two values $>20 \%$ at Station 512 together with means exceeding $10 \%$ at these two stations were noteworthy; however, a large amount of overlap among stations occurred (Fig. 25) and, as noted, differences among stations were not statistically significant (Table 17). In female carp collected from the MRB in 1995 the range of atresia was much greater than in the RGB; individual female fish with $>30 \%$ atretic eggs were found at many stations (McDonald and others, 2002). In the Hudson River (New York), Baldigo and others (2001) reported that atresia in carp was generally greatest (up to 20\%) at sites least contaminated by PCBs, and tended to be lowest $(<10 \%)$ at the most contaminated sites. They did not identify the fish to stage, however.

\section{Atresia in Bass}

Atresia occurred at comparatively low rates in bass at all stations and was generally less variable than in carp. The exception was two stage-4 fish with unusually large values from Station 514 (Fig. 25). As noted for carp, stage-0 female bass (obtained exclusively at Station 512, $n=2$; Fig. 21) contained small percentages (0-2\%) of atretic eggs (Appendix Table 6). Atresia in female bass tended to increase with 


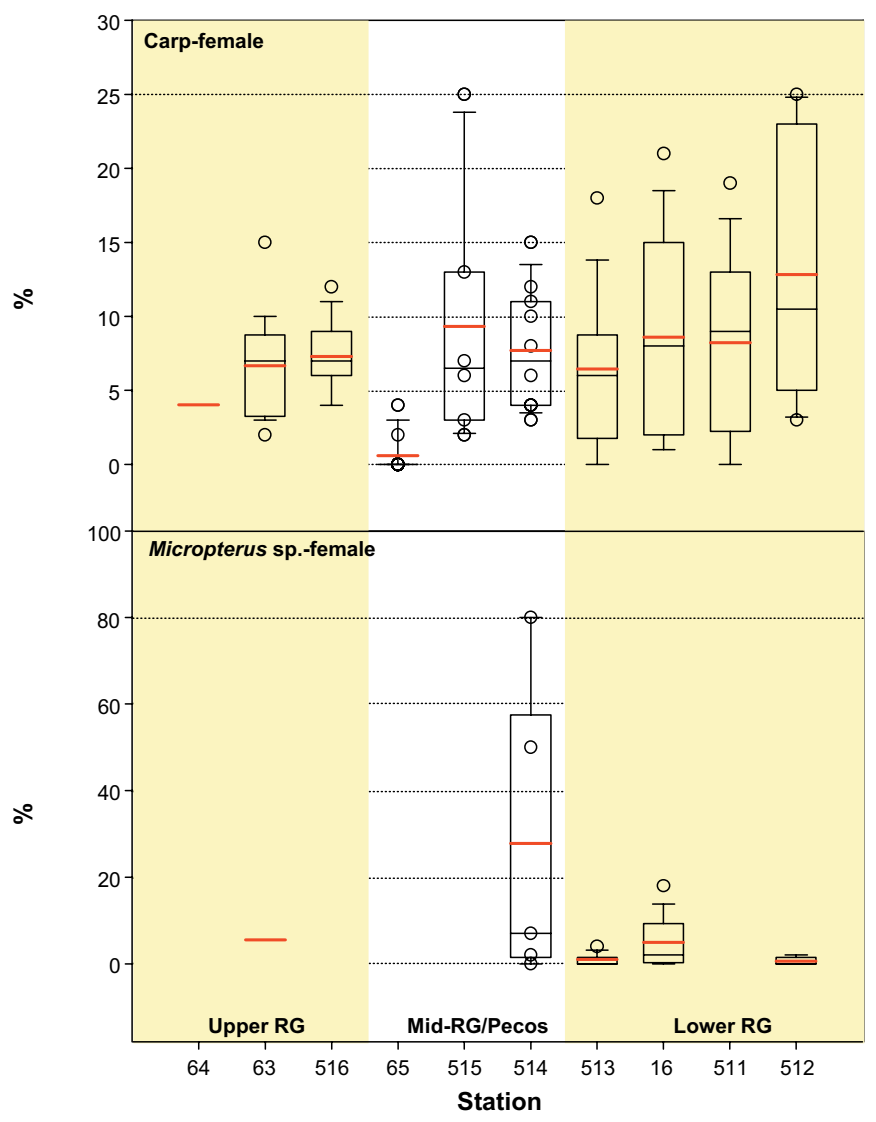

Figure 25. Percentage of atretic oocytes in female carp and bass (Micropterus sp.), by station. Shown for each group are points representing individual fish and the mean (red horizontal line), median (black horizontal line), interquartile range (box), and the 10th and 90th percentiles (whiskers). Stations are ordered from upstream to downstream and are grouped by sub-basin. See Table 1 for station descriptions and collection dates.

gonadal stage; the basin-wide atresia mean for stage- 1 was $2.8 \%$ (data not shown), with individual fish ranging from 0 to 18\% (Appendix Table 6). Most stage-1 fish had 0-10\% atretic eggs. Atresia values $>10 \%$ contributed to elevated stage- 1 means at Stations $16(5.3 \%)$ and $63(6.5 \%)$ compared to the other three stations (0.4-3.0\%; Appendix Table 6). Fish in later gonadal stages had slightly greater percentages; in four stage-2 females from Stations 16 and 513 it was $0-10 \%$ and it was $0-7 \%$ in the two stage-3 smallmouth bass from Station 63 (Fig. 25; Appendix Table 6). In contrast to findings for female carp, atresia was universally low (0-2\%) in female bass from Station 512 regardless of when the fish were collected. Atresia was $50-80 \%$ in the two stage- 4 female bass from Station 514 (Fig. 25). As noted in the discussion of gonadal stage, the collection of stage- 4 female bass in South Texas during November is in itself unusual. Further histopathological examination revealed heavy microsporidian parasite infections within the oocytes of these two fish (Fig. 26). Although the parasites did not appear to have penetrated the pre-vitellogenic oocytes, the more advance ones were affected; they consequently appeared to have progressed to stage 4 but were not released. The oocytes observed were in various stages of degeneration and necrosis and had begun to be reabsorbed (Fig. 26). Except for these two fish, the incidence of atresia in RGB bass was similar to what was reported for the MRB (McDonald and others, 2002). Although the ovaries of the fish were examined histologically, atresia was not reported in the female largemouth bass exposed to paper mill effluents in Florida by Sepúlveda and others $(2003 ; 2001)$. As they also reported for carp, Baldigo and others (2001) reported that atresia rates were greatest (up to 30\%) in bass (largemouth and smallmouth) from the Hudson River sites least contaminated by PCBs, and were lower (10-20\%) at more contaminated sites; however, these fish were also not identified to stage. As noted by McDonald and others (2000), atresia can be induced in fish by exposure to a number of contaminants; however, it is also important to note that other factors may also be involved (June, 1970; 1977).

\section{Ceroid Pigment}

Pigmented cell accumulations were present to varying degrees in the gonads of carp and bass from the RGB (Fig. 27). Pigment scores ranged from 0 (no ceroid pigment) to 3 (moderately large amount of pigment) and differed between genders (Appendix Table 6). Oxidation products can increase over time, so associations between age and ceroid pigment were also investigated. Preliminary statistical analysis indicated that pigment scores were correlated with age in female carp and bass but not in males of either species (data not shown). Except for female carp from Station 511, in which ceroid pigment scores tended to decrease with age, scores generally paralleled patterns in average age for both carp and bass (data not shown). Most fish of both taxa were scored as 0 or 1 for pigment accumulation, a total of five received a rating of 3 , and none received scores of 4 despite the collection of 7- and 8-y old fish from several stations (Appendix Table 6). Collectively, the results indicate that the fish were under little oxidative stress. In contrast, fish of several species obtained from resacas along the lower RG by Mora and others (2001) in 1996 contained high concentrations of ceroid/lipofuscin pigments; however, as noted with regard to MAs, these fish were not aged and it is consequently difficult to compare results of the two studies. The pigment data, because of its categorical nature and the confounding age factor, did not provide clear information with the limited numbers of fish collected in the RGB and the data were not investigated further.

\section{Ovotestis in Male Bass}

Intersex gonads were only observed in male bass, as was also true in the $1995 \mathrm{MRB}$ study (McDonald and others, 2002). Of the 30 male bass from four RGB stations examined (all largemouth except one smallmouth from Station 514), 10 (all largemouth) showed evidence of ovotestis as identified 


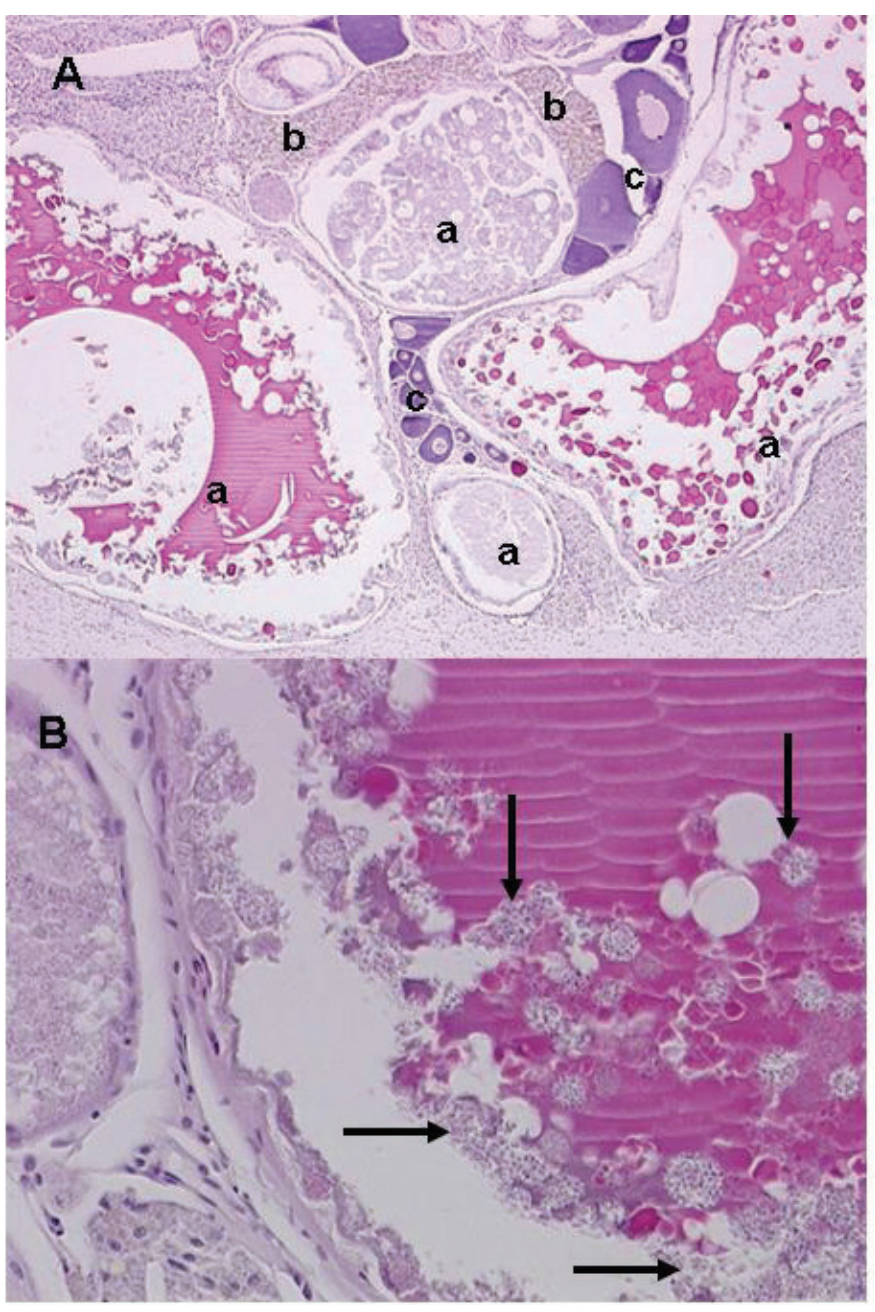

Figure 26. Ovarian section of a largemouth bass from Station 514 . A. Developing, vitellogenic oocytes in various stages of degeneration (a). Many ceroid/lipofuscin pigment accumulations (b) are also present. Previtellogenic oocytes (c) show no signs of infection. H \& E stain (X 40). B. Higher magnification (X 200) illustrating the presence of numerous microsporidian parasites (arrows).

by the presence of developing oocytes in an otherwise normal male gonad. This intersex condition was detected in two of 10 fish from Station 16, four of eight from Station 512, and four of nine from Station 513. None of three male bass from Station 514 (two largemouth, one smallmouth) examined were intersex, however. No gonad samples were obtained from the Station 63 male bass. All of the intersex fish were identified as being in either gonadal stage 1 or 2 .

Overall, relatively high percentages (20-56\%) of intersex male largemouth bass were found at stations in the lower RGB. In the MRB (McDonald and others, 2002), such high percentages were only observed in smallmouth bass from one site; the incidence in largemouth and spotted bass was lower $(<20 \%)$. In the Hudson River, Baldigo and others (2001) reported high incidences of intersex largemouth and smallmouth bass, but no intersex males were reported among the largemouth bass exposed to paper mill effluents in Florida by Sepúlveda and others $(2001 ; 2003)$.

The distribution of intersex bass in the RGB cannot be determined from our data because relatively few male bass (or gonad samples) were obtained. At least one intersex male bass was present at all the lower RG sites from which bass were obtained, but none were detected at Station 514, an upstream site; however, the sample size was small $(n=3)$. In addition, and in keeping with previous U.S. reports (Folmar and others, 1996; Goodbred and others, 1997; Lee and others, 2000; McDonald and others, 2002) no intersex male carp were found. No intersex fish were reported among the 18 fish (carp and other species) from resacas along the lower RG examined by Mora and others (2001). In contrast, in Europe intersex male carp and other cyprinids have been collected near sewage treatment plants (Jobling and others, 1998; Minier and others, 2002; Solé and others, 2002; 2003).

\section{Gonadosomatic Index (GSI)}

ANOVA models containing terms for station, sex, stage, and the interactions of these effects were significant for both carp and bass (Table 17). In carp, the model explained $72 \%$ of the total variation in GSI; differences among stations, but not between genders, were significant after accounting for all other factors in the model (Table 17). In bass the model accounted for $70 \%$ of the total variation in GSI. Differences between genders were significant, and among-station differences were marginally significant $(P=0.06$; Table 17$)$. As expected, stage and interactions containing stage were significant in both taxa (Table 17). Differences between stage-2 and -3 male carp, the most prevalent stages, were not significant, but few female bass were in any stage other than stage 1 at all sites (Fig. 21; Appendix Table 6).

\section{GSI in Carp}

Generally, female carp from Stations 16, 513, and 514 had proportionately larger ovaries than those from most other stations, but there was wide variation at the former (Fig. 28) that only partly corresponded to stage differences among the stations (Fig. 21). GSI in female carp ranged from $0.3 \%$ in a stage-0 fish from Station 511 to $36.4 \%$ in a stage-2 fish from Station 16 (Fig. 28; Appendix Table 6). All four stage-0 female carp were from Station 511 (mean GSI $=0.9 \%$, range $=0.3-1.3 \%$; Appendix Table 6). As noted previously, $92 \%$ of the female carp examined were in gonadal stage 2 (Fig. 21). Basin-wide the mean GSI for stage- 2 females was $14.8 \%$ with individual fish ranging from $3.3 \%$ to $36.4 \%$. Most stage-2 GSI values were between $6.2 \%$ and $22.0 \%$, and stage- 2 station means ranged from 5.2\% at Station 515 to $19.5 \%$ at Station 514 (Appendix Table 6). Other stations with stage-2 means $<11.5 \%$ included 511, 512, 63, and 65; means for all other 

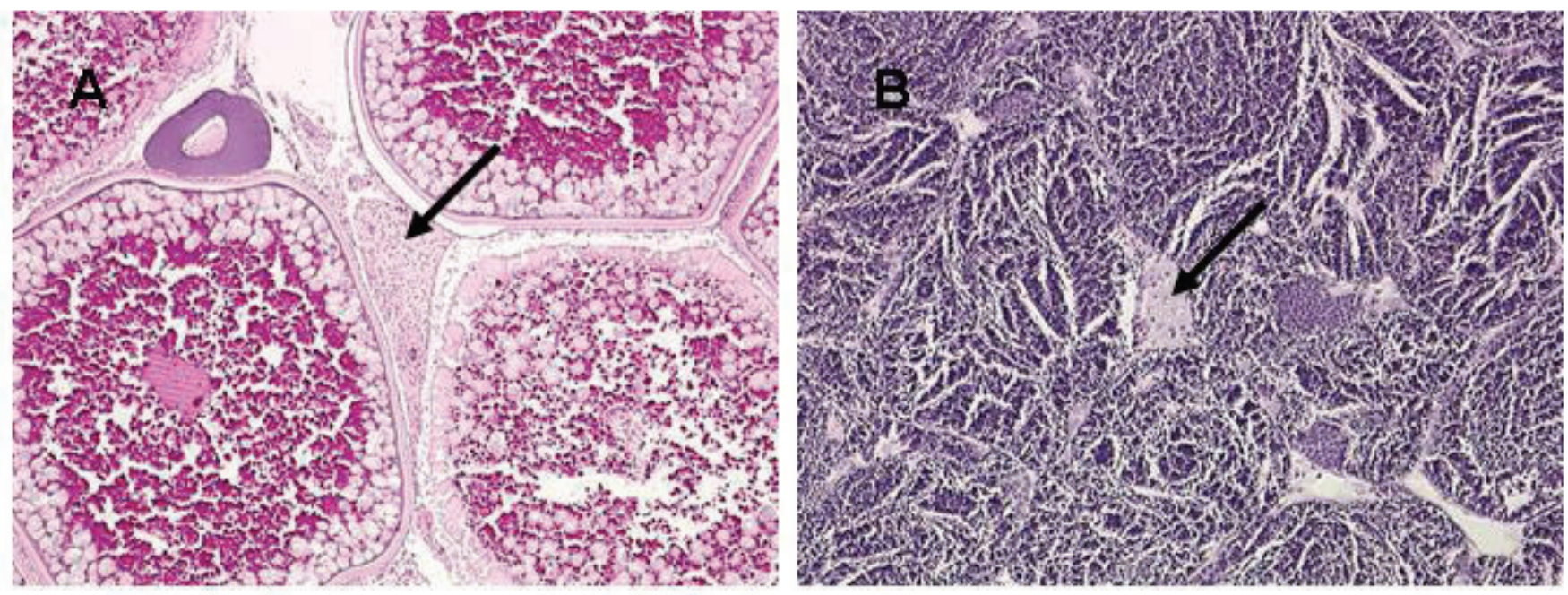

Figure 27. Pigmented cell accumulations (arrows) in the gonads of carp from the Rio Grande Basin. The amount of these ceroid-lipofuscin pigments was rated on a scale of 0 (no pigment) to 4 (heavily pigmented). A. Ovary of female carp. H \& E stain (X 165). B. Testes of male carp. H \& E stain (X 412).

stations were $>15.0 \%$ (Appendix Table 6). At Stations 513, 514 , and 64, all but one or two stage-2 fish had GSI values that exceeded the basin-wide mean. Conversely, individual stage-2 values $>22.0 \%$ occurred at Stations 16, 64, and 514. Stage-1 females were present at Stations 63, 511, 512, 513, and 516 (Fig. 21). The basin-wide mean for stage-1 female carp was $5.1 \%$ with a range of $0.5 \%-18.2 \%$ (Appendix Table 6). Station means ranged from $1.3 \%$ at Station 513 to $8.9 \%$ at Station 512; one stage- 1 female carp from Station 516 had a GSI of $18.2 \%$. Except for the maximum, all GSI values for stage-1 female carp were $<10.0 \%$.

The distribution of GSI in male carp generally paralleled that of female carp and, like the females, was partly related to stage differences (Figs. 21 and 28). The one stage-1 male carp from Station 16 had a GSI of only $0.2 \%$ (Appendix Table 6). Most male carp were in stage 3 (Fig. 21). The basin-wide mean GSI for males in stages 2 and 3 was $8.7 \%$, with individual values ranging from $2.2 \%$ to $20.3 \%$ (Fig. 28; Appendix Table 6). Most values were between $3.0 \%$ and $12.5 \%$. Station means for stage- 2 male carp ranged from $4.2 \%$ at Station 511 to $11.8 \%$ at Station 514 (Appendix Table 6). Station means for Stations 16, 64, 513, 514, and 516 exceeded the basinwide mean as did that of most individual male carp from these stations (Fig. 28). Conversely, relatively low station means characterized male carp from Stations 65, 512, and 515, and all individual values for these stations were less than the basinwide mean (Fig. 28). Wainwright and others (2001) noted that male carp collected from one resaca sampled in July-August 1997 had comparatively high GSI values (4.68-6.46\%) relative to other resacas and settling basins, and that plasma androgen levels and DDE concentrations were also elevated in these fish. These values are similar to most of those we report for stage-1 and -2 male carp (Appendix Table 6). Although collected at least a month earlier than most of our fish, the carp examined by Wainwright and others (2001) were described as being in the "spermatid" gonadal stage, which is equivalent to our Stages 1 and 2. Therefore, the GSI values report by both studies are similar.

\section{GSI in Bass}

In female bass all GSI values were between $0.25 \%$ and $1.2 \%$ except for three fish-one (of two) stage- 3 smallmouth bass from Station $63(1.8 \%)$ and one stage-2 largemouth bass from each of Stations 16 (1.5\%) and 513 (1.5\%) (Fig. 28; Appendix Table 6). Most GSI values were between $0.35 \%$ and 1.0\% (Fig. 28; Appendix Table 6). The basin-wide mean for GSI in stage- 1 female bass was 0.68 , with station means ranging from 0.59 at Station 513 to 0.83 at Station 514, (Appendix Table 6). At Station 514, all stage-1 fish exceeded the basinwide mean, but no values were especially high or low. Two stage-0 female bass from Station 512 averaged $0.47 \%$ (range $0.43-0.49 \%$ ); the two stage- 3 smallmouth bass from Station 63 averaged 1.28 (range 0.74-1.80); the mean GSI for three stage-2 females from Station 16 was 1.06 (range 0.72-1.46); and the GSI of one Stage-2 female from Station 513 was 1.49 (Fig. 28; Appendix Table 6). The ovaries of the two stage-4 females from Station 514 were not especially large; GSI averaged $0.64 \%$ in these two fish (range 0.61-0.68\%; Appendix Table 6). These were the same fish identified previously as having high percentages of atretic eggs and heavy microsporidian infections within the oocytes (Fig. 26). Although in later gonadal stages than all other female bass from the RGB examined, the gonads of these two fish were proportionally smaller (lower GSI) than many fish in earlier gonadal stages. Overall, most GSI values in female bass from the RGB were lower than those observed in female largemouth bass exposed 


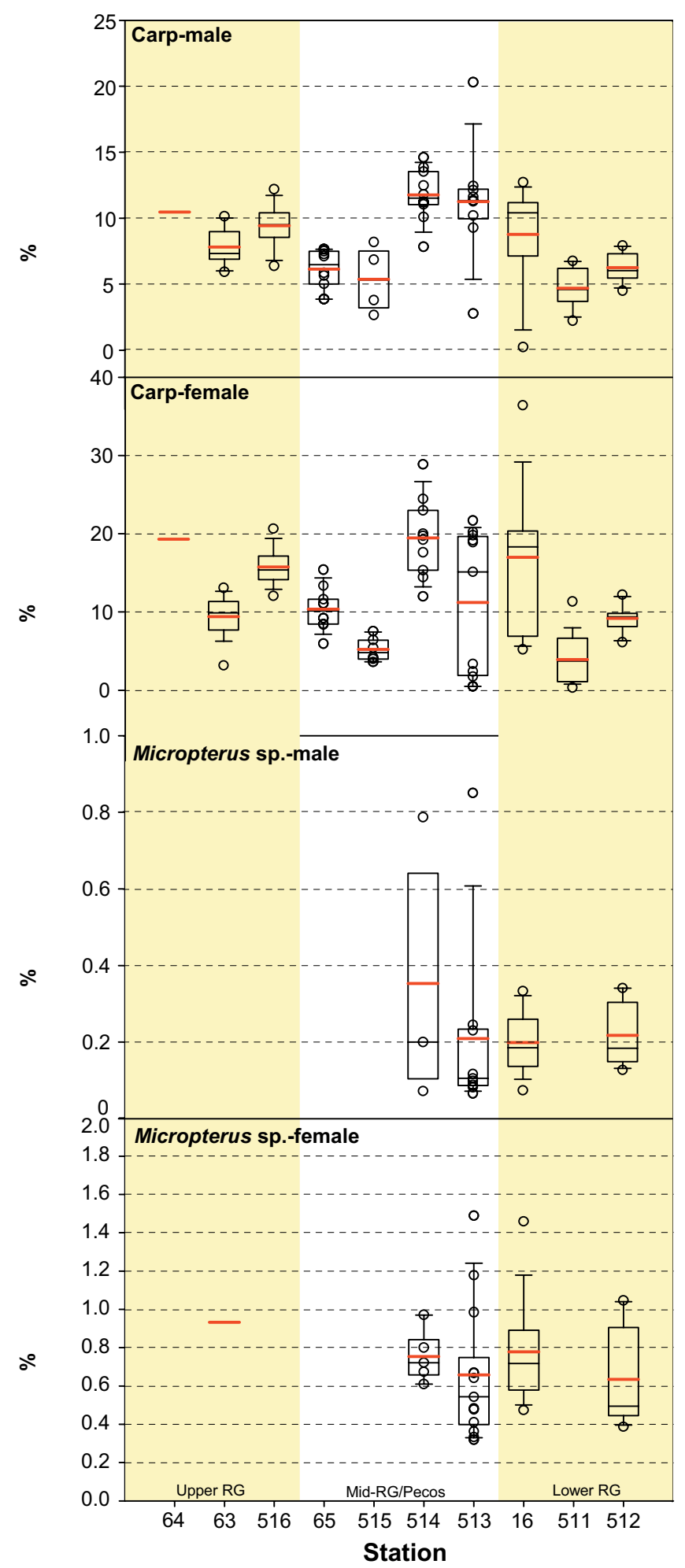

Figure 28. Gonadosomatic index (GSI) values of male and female carp and bass (Micropterus sp.), by station. Shown for each group are points representing individual fish and the mean (red horizontal line), median (black horizontal line), interquartile range (box), and the 10th and 90th percentiles (whiskers). Stations are ordered from upstream to downstream and are grouped by subbasin. See Table 1 for station descriptions and collection dates. to paper mill effluents in Florida by Sepúlveda and others (2001; 2003), but as noted previously the Florida study was conducted in the Spring.

GSI values in male bass were all between $0.1 \%$ and $0.4 \%$ except for two fish with unusually large gonads relative to all others irrespective of stage: a stage-2 largemouth bass from Station $513(0.9 \%)$ and the stage-3 smallmouth bass from Station 514 (0.8\%) (Fig. 28; Appendix Table 6). Station means and ranges for GSI in male bass did not differ greatly among stations, however. At Stations 16, 512, 513, and 514 the station means for stage- 2 male bass ranged from $0.14 \%$ to $0.22 \%$ (Appendix Table 6). No station-stage combination represented by more than one fish differed notably from the others. As described for females, all GSI values for male RGB bass except the two values noted were smaller than those (including controls) reported for male largemouth bass from Florida examined by Sepúlveda and others $(2001 ; 2003)$. And, as also noted, the Florida study was conducted in the Spring.

\section{Vitellogenin (Vtg)}

Concentrations of vtg in most male carp and bass were below the LOD $(<0.005 \mathrm{mg} / \mathrm{mL}$ in carp, $<0.002 \mathrm{mg} / \mathrm{mL}$ in bass; Appendix Table 6), so these were not analyzed statistically. In female carp, ANOVA indicated that age and gonadal stage, as well as several interaction terms involving these factors, significantly influenced vtg concentrations (Table 17). The model accounted for $87 \%$ of the total variation in vtg concentrations, but differences among stations were not significant after the other factors (stage, age, and so forth) were accounted for (Table 17). In female bass this model was also significant and accounted for $80 \%$ of the total variation, but no individual factors or their interactions were significant and, as was true for female carp, differences among stations were not significant after accounting for all other factors (Table 17). However, large numbers of bass scales were regernerated and could not be read, and the statistical analysis incorporated relatively few fish. Based on the results of previous studies (for example, McDonald and others, 2002) it is likely that stage would have been significant had more fish been included in the analysis. For this reason, results for vtg in female carp and bass are presented and discussed by gonadal stage.

\section{Vtg in Female Carp}

Overall, vtg in female carp ranged from $<0.005 \mathrm{mg} / \mathrm{mL}$ in a few fish from several stations to $4.3 \mathrm{mg} / \mathrm{mL}$ in a stage2 fish from Station 514 (Fig. 29; Appendix Table 6). As expected, vtg concentrations in female carp increased with stage. Concentrations in the four stage-0 fish from Station 511 were all $<0.005 \mathrm{mg} / \mathrm{mL}$ whereas in the other stages present $(1$ and 2) they averaged $1.2 \mathrm{mg} / \mathrm{mL}$ and $2.8 \mathrm{mg} / \mathrm{mL}$, respectively (Appendix Table 6). The basin-wide mean for stage- 1 females was $1.1 \mathrm{mg} / \mathrm{mL}$, with concentrations ranging from below detection $(<0.005 \mathrm{mg} / \mathrm{mL}$ ) to $3.1 \mathrm{mg} / \mathrm{mL}$ (Appendix Table 


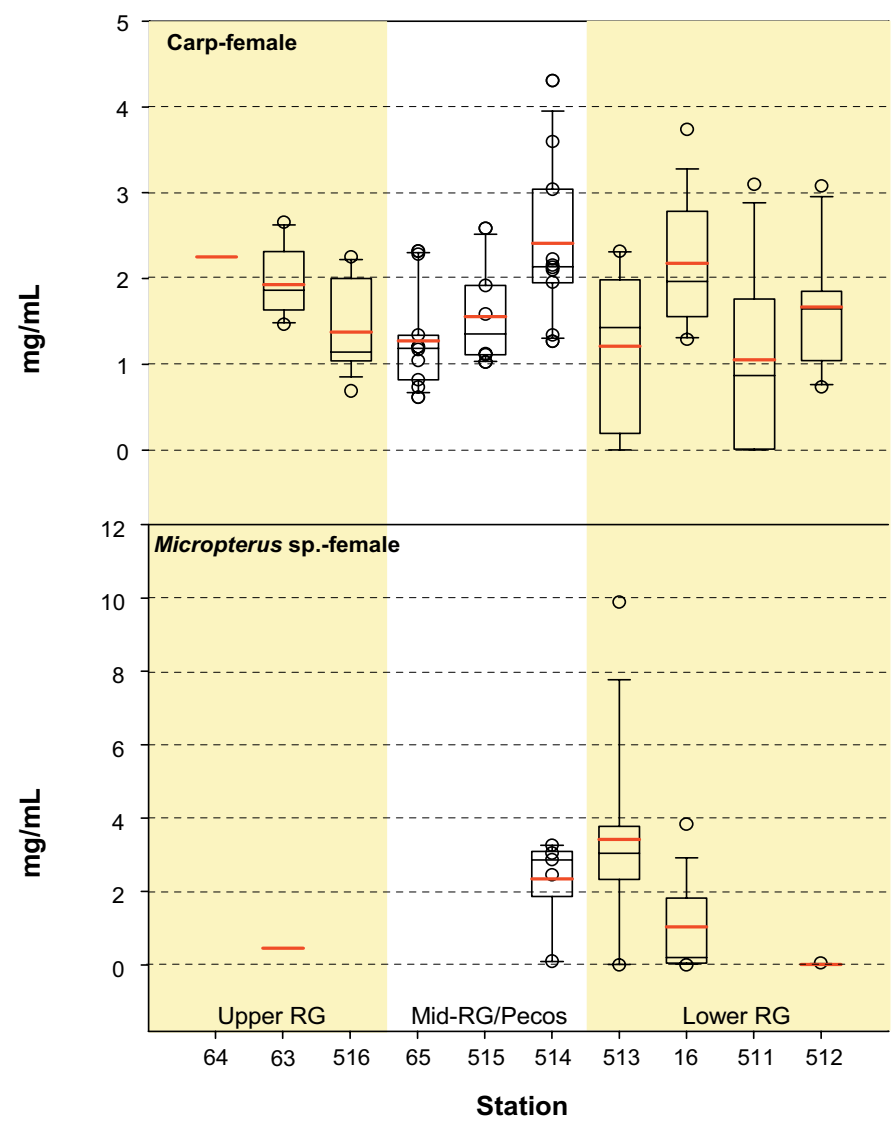

Figure 29. Plasma vitellogenin (Vtg) concentrations in female carp and bass (Micropterus sp.), by station. Shown for each group are points representing individual fish and the mean (red horizontal line), median (black horizontal line), interquartile range (box), and the 10th and 90th percentiles (whiskers). Stations are ordered from upstream to downstream and are grouped by sub-basin. See Table 1 for station descriptions and collection dates.

6). The mean for stage- 1 female carp from Station 513 was low $(0.1 \mathrm{mg} / \mathrm{mL})$ relative to the other four stations from which stage 1 females were obtained (means $=1.2-2.0 \mathrm{mg} / \mathrm{mL}$; Appendix Table 6). Concentrations in stage-2 female carp ranged from 0.6 to $4.3 \mathrm{mg} / \mathrm{mL}$ with a mean of $1.9 \mathrm{mg} / \mathrm{mL}$. Most values were between 1.0 and $3.0 \mathrm{mg} / \mathrm{mL}$ (Appendix Table 6), and station means ranged from 1.3 (Station 65) to 2.4 $\mathrm{mg} / \mathrm{mL}$ (Station 514; Appendix Table 6). Except for the low concentrations in stage-1 females from Station 513, no station appeared to differ greatly from the others and overall differences among stations were not statistically significant (Fig. 29; Table 17; Appendix Table 6).

\section{Vtg in Male Carp}

Vtg concentrations in 77 of 91 male carp (85\%) were below the LOD $(<0.005 \mathrm{mg} / \mathrm{mL}$; Appendix Table 6). Concentrations exceeded the LOD in at least one fish from Stations 16, 63, 64, 511, 514, and 515 (Appendix Table 6). Except for one stage-2 fish from Station 511, all male carp with detected concentrations were in stage 3 (Appendix Table 6), and most of the measured concentrations were low $(<0.02 \mathrm{mg} / \mathrm{mL})$. Only three values exceeded $0.02 \mathrm{mg} / \mathrm{mL}$; these were in fish from Stations $64(0.08 \mathrm{mg} / \mathrm{mL})$ and $511(0.8$ and $1.6 \mathrm{mg} / \mathrm{mL}$; Appendix Table 6). The greater of these concentrations (1.6 $\mathrm{mg} / \mathrm{mL}$, Station 511) is within the normal range of early to mid-vitellogenic (stage-1 or -2) female carp as identified in this and other studies (Goodbred and others, 1997; McDonald and others, 2002). This value is also within the range of concentrations induced in male carp exposed to sewage (Folmar and others, 1996) and to $17-\beta$ estradiol in laboratory studies (Folmar and others, 2001). Similar sporadic occurrences of male carp with comparatively high vtg concentrations have been noted in previous field studies (McDonald and others, 2002; Smith and others, 2002).

\section{Vtg in Female Bass}

Vtg Concentrations in female bass also increased with gonadal stage. Concentrations were $<0.002 \mathrm{mg} / \mathrm{mL}$ in two stage-0 fish from Station 512 vtg (Appendix Table 6). In stage-1 females, which were obtained at all five stations from which bass were collected, the overall mean concentration was $1.5 \mathrm{mg} / \mathrm{mL}$, with values for individual fish ranging from below detection $(<0.002 \mathrm{mg} / \mathrm{mL}$ ) to $9.9 \mathrm{mg} / \mathrm{mL}$ (Appendix Table 6). Mean vtg concentration was $0.03 \mathrm{mg} / \mathrm{mL}$ in the two stage-3 female smallmouth bass from Station 63 and $3.1 \mathrm{mg} / \mathrm{mL}$ in the two stage-4 females from Station 514. The ovaries of the latter were infected with microsporidian parasites (Fig. 26). The overall mean for stage- 2 females, which were obtained at Stations 16 and 513, was $3.8 \mathrm{mg} / \mathrm{mL}$ (range 1.9-7.2 mg/mL). Concentrations in most fish ranged from below detection to $3.5 \mathrm{mg} / \mathrm{mL}$ (Fig. 29). The station mean was lowest at Station $512(0.01 \mathrm{mg} / \mathrm{mL})$ and greatest at Station $513(3.1 \mathrm{mg} / \mathrm{mL})$ (Fig. 29; Appendix Table 6). Overall, differences among stations were not statistically significant, nor were any other factors or interactions (Table 17). Except for the consistently low values at Station 512 and the one fish from Station 513 with a relatively high concentration $(7.2 \mathrm{mg} / \mathrm{mL})$, concentrations in most stage- 1 female bass were similar. The two highest concentrations in female bass, regardless of stage, were in fish from Station 513 (Fig. 29).

\section{Vtg in Male Bass}

Vtg was not detected $(<0.002 \mathrm{mg} / \mathrm{mL})$ in 26 of the 27 male bass analyzed (96\%; Appendix Table 6). The one exception was a stage- 2 fish from Station 513 with a concentration of $3.15 \mathrm{mg} / \mathrm{mL}$, which is well into the range of mid-vitellogenic female bass collected in this and other studies (for example McDonald and others, 2002). Concentrations in this range have been detected in male fish of other species exposed to sewage (Folmar and others, 1996) and to 17- $\beta$ estradiol in the laboratory (Folmar and others, 2001), but not in largemouth 
bass exposed to paper mill effluents; in the latter plasma vtg concentrations were reduced relative to controls (Sepúlveda and others, 2001; 2003). Liver size is also influenced by vtg synthesis. The HSI of the male bass from Station 513 with the elevated vtg concentration was $1.03 \%$, which was within the range of bass from other RGB sites (Fig. 14). It was also one of the four intersex males collected at Station 513 (Appendix Table 6). In contrast, one male bass from this site had a very large liver (2.3\%; Fig. 14), but its vtg concentration was low $(<0.002 \mathrm{mg} / \mathrm{mL})$ and it was histopathologically unremarkable. As noted for male carp, sporadic occurrences of male bass with comparatively high vtg concentrations have been noted in previous field studies (Baldigo and others, 2001; McDonald and others, 2002).

\section{Reproductive Biomarkers: Summary}

Both male and female carp from Station 511 (AC at Harlingen) were in earlier gonadal stages than those at all other stations. However, fish were collected at Station 511 during late September-early October, 4-8 weeks before all other stations in the lower RGB. Therefore, some of the stage difference may reflect the sampling date, and these stage differences probably also influenced other reproductive biomarkers. Bass from Station 512 were also in slightly earlier stages than those from the other three stations from which bass gonads were obtained for examination (females only from Station 63). Fish were collected in the RGB over a 4-month period; although most were obtained between late September and early December 1997, Station 65 was not sampled until late January 1998 (Table 1). Nevertheless, carp from Station 65 were in the same stages (females all stage 2, males all stage 3 ) as nearby stations that were sampled earlier (Fig. 21). Thus, it does not appear that reproductive biomarker results at sites other than Station 511 were confounded by sampling period differences.

Reproductive biomarker measurements of note were determined primarily through comparison with the 1995 MRB study (McDonald and others, 2002) and the literature. For atresia, McDonald and others (2002) defined high percentages as $\geq 25 \%$ for female carp and $>10 \%$ for female bass. In the RGB, most female carp had $<20 \%$ atresia whereas most female bass had $<10 \%$. High individual values were found in both carp and bass from Station 16, but only in bass from Stations 512 and 514. Values in female bass from Station 514 were greater than any reported in bass previously, and were related to a parasite infection (Fig. 26). The ovaries of one female carp from Station 64 contained no normal gonad tissue, only necrotic, degenerated follicles (Fig. 23).

To our knowledge, the background occurrence of intersex male bass has not been established. We therefore recorded where they were found and at what frequency, but have no criteria for comparison. Intersex male bass were detected at three of the four RGB sites from which gonads were available for examination; none (of only three examined) were observed in fish from Station 514, and gonad samples were not obtained from Station 63 male bass. Ovotestis was detected in four of eight male bass from Station 512, four of nine from Station 513, and two of 10 from Station 16. Ovotestis was detected exclusively in largemouth bass, but only one male smallmouth bass (from Station 514) was examined. In contrast to bass, ovotestis was not detected in carp from any of the sites investigated.

Differences between carp and bass were obvious for GSI; as noted in previous studies (for example, McDonald and others, 2002), gonads constituted a substantially greater proportion of the total body mass in carp than in bass. Amongstation differences were statistically significant in carp; GSI values were higher than most in male carp and stage- 2 female carp from Station 514. Although not significantly different, GSI was also greater in stage-1 female bass from Station 514 than at other stations. Other stations at which GSI values in carp were comparatively high (mean or individual fish) included Stations 64 and 513. Wainwright and others (2001) noted that elevated GSI in male carp from resacas and settling basins in the lower RG valley were positively correlated with plasma androgen concentrations and with carcass concentrations of $p, p$ '-DDE. Conversely, GSI in carp was lower than most at Stations 511, 512, and 515, as it also was in female bass from Stations 512 and 513 (Fig. 28). The ovaries of the parasite-infected stage-4 female bass from Station 514 (Fig. 26) were proportionately smaller than many fish in earlier gonadal stages.

Vtg concentrations in female carp did not appear abnormal at any station. In contrast, vtg concentrations in two male carp from Station 511 were within the range of early- to midvitellogenic females, a condition that has been associated with the exposure of male fish to exogenous estrogens in both field and laboratory studies. In addition, and keeping with the findings of most U.S. field studies (Goodbred and others, 1997; Lee and others, 2000; McDonald and others, 2002; Solé and others, 2002), none of the vitellogenic male carp were intersex. These findings contrast with those of a study of reproductive biomarkers in another European cyprinid (roach, Rutilus rutilus) collected near sewage treatment plants in the U.K.; in this study, the proportion of intersex fish and the severity of the intersex condition were greater, and the mean vtg concentration of the intersex males was intermediate between that of males and female controls (Jobling and others, 1998). In the RGB, relatively high vtg concentrations in stage- 1 female bass and an elevated concentration in one male bass were detected at Station 513. The vtg concentration in this latter fish as well as those in the two male carp from Station 511 were within the range of concentrations shown to induce pathological changes in the liver of male fish exposed to 17- $\beta$ estradiol in laboratory studies (Folmar and others, 2001). In contrast to male bass from Station 513, no male carp from this station had vtg concentrations greater than the detection limit. However, Stage-1 female carp from this site had very low vtg concentrations relative to all others. At Station 512, vtg concentrations 
in female carp appeared normal but concentrations in female bass were uniformly low.

\section{Spatial Patterns in Contaminant Concentrations and Biomarker Responses}

\section{Upper Rio Grande (Stations 64, 63, and 516)}

Contaminant concentrations in fish from the upper basin were generally low, and most biomarker responses were unremarkable (Figs. 30 and 31; Table 22). Contaminant concentrations in carp and northern pike from Station 64 (RG at Alamosa, CO) were universally low; however, the ovaries of one female carp contained only necrotic follicles (Fig. 23). EROD rates in several carp were also minimally indicative of exposure to exogenous AhR ligands; however, PCB and TCDD-EQ concentrations were relatively low (Figs. 9, 10, and 32 ), indicating that the fish had probably been exposed to PAH (Table 4). Station 64 is situated downstream from the influence of the Creede mining district where degraded water quality and elevated metals concentrations in fish and other matrices have been documented in the past (Levings and others, 1998). Station 63 (Elephant Butte Reservoir) was the most contaminated of the three upper basin sites. Concentrations of $\mathrm{Hg}$ were elevated in predatory fishes (Figs. 3 and 31; Table 22 ), as they have been in the past, and elevated EROD rates in carp and female bass (no males were obtained) were consistent with exposure of the fish to exogenous AhR ligands (Figs. 10 and 32; Table 22). Because concentrations of PCBs and
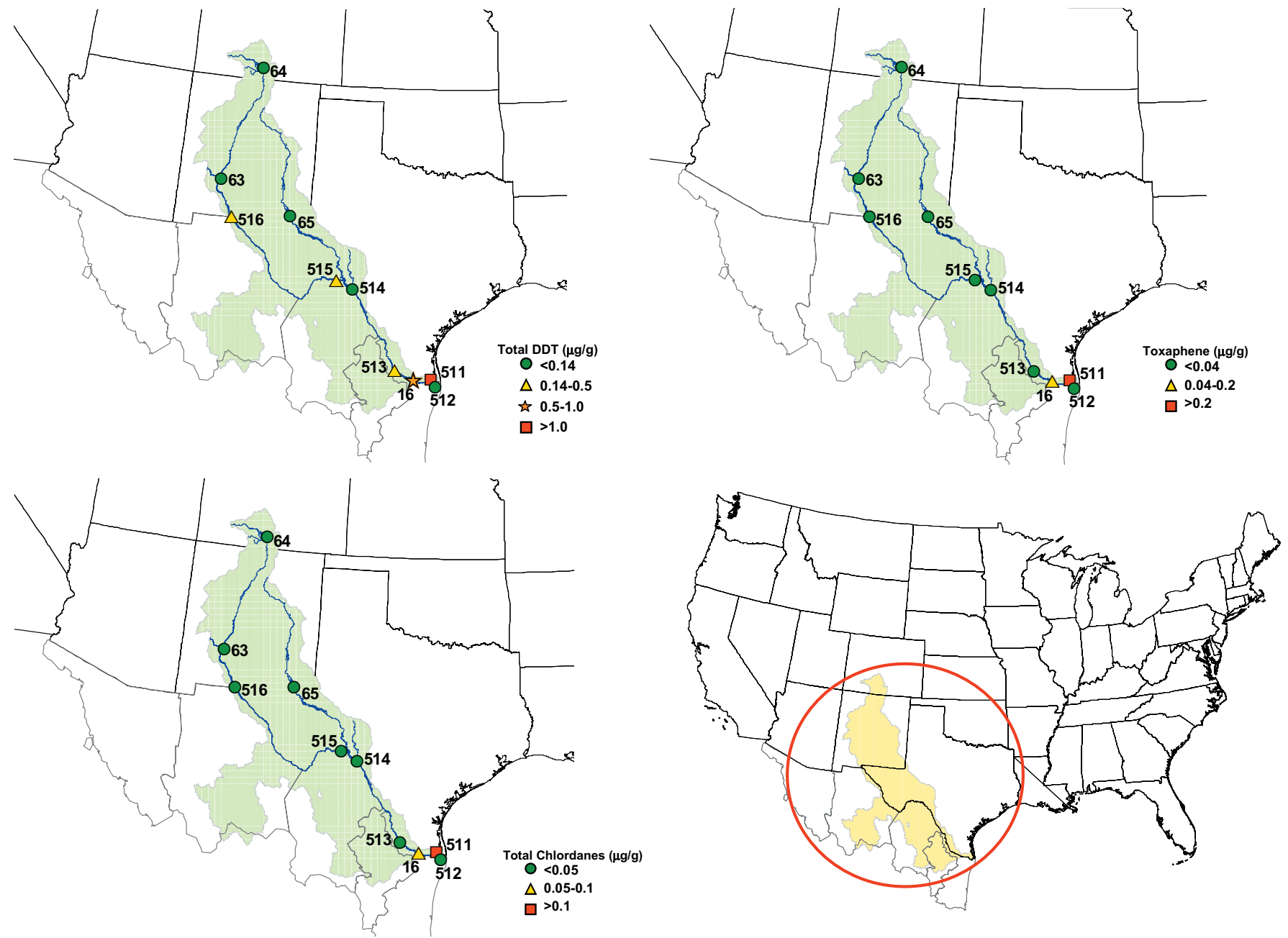

Figure 30. Maximum concentrations of total DDT ( $p, p^{\prime}$-homologs), toxaphene, and total chlordanes (sum of six components) in composite samples of whole fish. Total DDT concentrations of $0.15 \mu \mathrm{g} / \mathrm{g}$ are potentially harmful to the brown pelican (Pelicanus occidentalis), the most sensitive avian species (Anderson and others, 1975), and 1-3 $\mu \mathrm{g} / \mathrm{g}$ is potentially harmful to other piscivorous birds (Blus, 1996). For toxaphene, reviews by Jarvinen and Ankley (1999) and Eisler and Jacknow (1985) noted acute and chronic effects on freshwater fish at whole-body concentration $\geq 0.04 \mu \mathrm{g} / \mathrm{g}$. For chlordane, concentrations $>0.1 \mu \mathrm{g} / \mathrm{g}$ may affect the health of predatory fish and piscivorous birds (Eisler, 1990). See Table 1 for station descriptions and collection dates and text for explanation of chlordane components. 

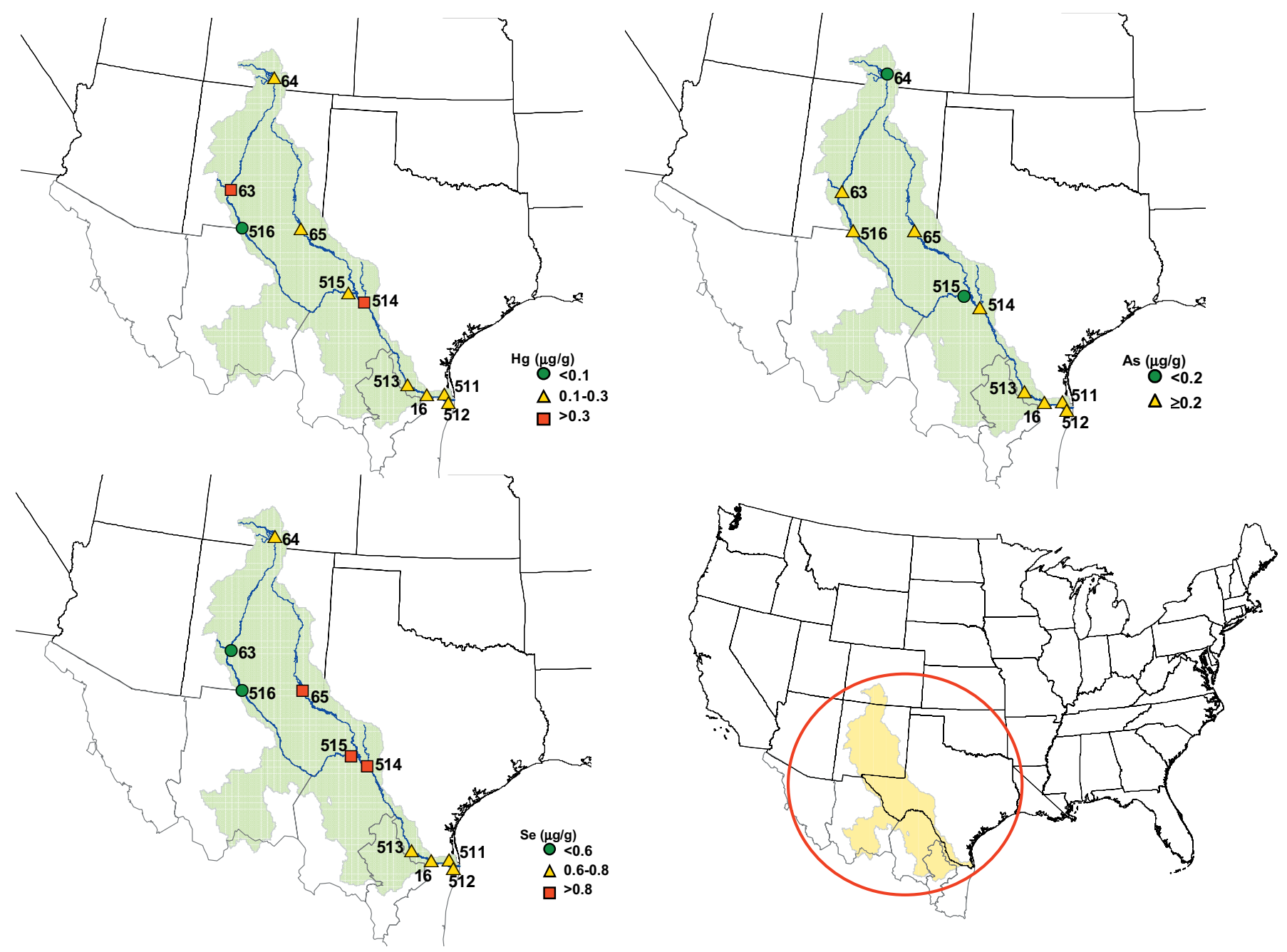

Figure 31. Maximum concentrations of mercury $(\mathrm{Hg})$, arsenic $(\mathrm{As})$, and selenium $(\mathrm{Se})$ in composite samples of whole fish. An $\mathrm{Hg}$ concentration of $\mathrm{Hg} 0.1 \mu \mathrm{g} / \mathrm{g}$ in fish has been suggested as a guideline for the protection of piscivorous mammals (Yeardley and others, 1998), and concentrations of $0.3 \mu \mathrm{g} / \mathrm{g}$ cause reproductive impairment in the common loon (Gavia immer) (Wiener and Spry, 1996; Wiener and others, 2002). For Se, concentration should be $<0.6 \mu \mathrm{g} / \mathrm{g}$ to avoid toxicity to piscivorous wildlife and $<0.8 \mu \mathrm{g} / \mathrm{g}$ to avoid toxicity to fish (Lemly, 1996). Arsenic is not considered harmful to fish or wildlife at the concentrations present in RGB fish; the indicated thresholds are arbitrary and were selected for illustration only. See Table 1 for station descriptions and collection dates.

TCDD-EQ were low (Figs. 9 and 32), these EROD rates suggest exposure to PAH at this site (Table 4). The HAI scores of a few individual carp and bass from Station 63 were also comparatively high (Fig. 12) and CF was lower in carp than at some other RGB sites (Fig. 13); however, all values were within the range of those reported for carp in other studies. Vtg concentrations in the two stage- 3 female smallmouth bass from Station 63 were lower than stage-2 females largemouth bass from other stations; however, female smallmouth bass were not obtained elsewhere in the RGB. In addition, male gonads were not obtained from Station 63 bass, so the incidence of ovotestis at this site could not be determined. At Station 516 (RG at El Paso) concentrations of DDT were elevated (total p,p' homologs $0.21 \mu \mathrm{g} / \mathrm{g}$, mostly as DDE) in carp (Figs. 7 and 30). Slightly elevated EROD rates in carp from this site also indicated exposure to exogenous AhR ligands (Fig. 10); however, as was true for most RGB sites, PCB and TCDD-EQ levels were low (Figs. 9, 10, and 30). Nevertheless, it should be noted that in contrast to others sites in the upper basin and despite the lack of detectable PCB residues in the fish, PCBs were detected in sediments from this site by previous investigations (Appendix Table 1).

Except for Station 63, where $\mathrm{Hg}$ contamination has been well documented, relatively little extant information was available for the stations upstream of El Paso other than the NCBP (Schmitt and others, 1999b), NAWQA (Carter and Anderholm, 1997; Healy, 1997; Levings and others, 1998), and the studies by Ong and others (1991) and Roy and others (1992). Concentrations of organochlorine chemical residues were historically low in NCBP fish from these stations and declined 
Table 22. Summary of chemical and biological indicator results, by sub-basin and station. Within each column, colors indicate the severity, incidence, or both of the indicated condition or conditions at each station (green<yellow<orange<red). These designations are relative; see text for explanations. Male $(\mathrm{m})$ and female $(\mathrm{f})$ bass ${ }^{\mathrm{a}}$ and carp ${ }^{a}$ were collected from all sites unless otherwise indicated. If gender is not specified, then the indicated condition was present in both. See footnote ${ }^{\text {a }}$ for additional abbreviations and Table 1 for station locations and collection dates.

\begin{tabular}{|c|l|l|l|}
\hline Station & Contaminants and EROD activity & $\begin{array}{l}\text { Fish health } \\
\text { indicators }\end{array}$ & Reproductive biomarkers \\
\hline Upper Rio Grande basin & & \\
\hline 64 & EROD (c) & & vtg (mc), ovarian degeneration (fc, $n=1)$ \\
\hline 63 & Cr (mc), Hg (b, stb), EROD (c, b) & CF (c-), HAI (c, b) & vtg (fb-) \\
\hline 516 & DDE (c), EROD (c) & HAI (c) & \\
\hline Middle Rio Grande basin & & \\
\hline 65 & As (mwb, mc), Se (mwb, mc, fc), EROD (c, b) & CF (c-) & \\
\hline 515 & Se (c) & EL (c), HAI (c) & stage (fb); atresia (fb); ceroid (fb); GSI \\
\hline 514 & As (c), Se (c, b), Hg (b) & SSI (b) & \\
\hline Lower Rio Grande basin & HAI (c, b) & vtg (mb), ovt (mb) \\
\hline 513 & Ni (fb), Cr (fb), EROD (b) & ovt (mb) \\
\hline 16 & Pb (fb), DDE (mc) & HAI (c) $), ~$ & stage (c), vtg (mc) \\
\hline 511 & $\begin{array}{l}\text { DDE (mc, ccf), tox (c, ccf), chlordane (ccf), } \\
\text { dieldrin (ccf), EROD (c, ccf) }\end{array}$ & $\begin{array}{l}\text { CF (c-), HAI (b-), } \\
\text { MA (mc, fc) }\end{array}$ & stage (b), atresia (fc), ovt (mb), vtg (fb-) \\
\hline 512 & As (fb), Ni (mc), TCDD-EQ (mb), EROD (c, b) & \\
\hline
\end{tabular}

${ }^{a}$ DDE, $p, p$ '-DDE; tox, toxaphene; chlordanes, sum of cis- and trans chlordanes and nonachlors; oxychlordane; and hepatochlor epoxide; TCDDEQ, dioxin-like activity as determined by H4IIE bioassay; As, arsenic; Cr, chromium; Hg, mercury; Pb, lead; Ni, nickel; Zn, zinc; EROD, ethoxyresorufin $O$-deethylase activity; EL, external lesions; CF, condition factor; vtg, vitellogenein; HAI, health assessment index; SSI, splenosomatic index; HSI, hepatosomatic index; GSI, gonadosomatic index; ovt, ovotestis; MA, macrophage aggregates (one or more parameters); b, bass (Micropterus spp.); c, carp (Cyprinus carpio); ccf, channel catfish (Ictalurus punctatus); wb, white bass (Morone chrysops); stb, striped bass (Morone saxatilis); - indicates that the response or condition was smaller or lower than most; all others larger or greater.

further through 1997. NAWQA also sampled water, bed sediments, and fish tissues in 1992-1993 from a site near Station 64; minimal organic contamination was detected in fish tissues and sediments, and concentrations of dissolved constituents in water were low. Although trace elements emanating from the Creede, CO mining district were elevated in carp livers in the NAWQA study, elemental concentrations in 1997 samples of whole fish from Station 64 were universally low. Ong and others (1991) also reported low concentrations of most analytes in fish collected from the RG upstream of Elephant Butte Reservoir during the 1980s. A review of local influences found few sources of direct releases of contaminants to waterways around these upper-basin sites (Appendix Table 1).

Few altered biomarkers (only elevated EROD and HAI in several carp; Figs. 10 and 12) were noted in the fish from Station 516 (RG at El Paso), and only total DDT (mostly DDE) exceeded threshold concentrations for toxicity to fish and wildlife (Figs. 6, 7, 30, and 32; Table 22). These findings generally followed the overall upstream-downstream trend evident in the 1997 results. NASQAN analyses of water during 1995-97 detected traces of several water-soluble pesticides at this site (Appendix Table 1). The NAWQA program also reported low levels of water-soluble pesticides at El Paso as well as traces of $p, p^{\prime}$-DDE in bed sediments (Carter and Anderholm, 1997; Healy, 1997; Levings and others, 1998). The latter finding agrees with the 1997 fish data for Station 516 (Figs. 6 and 7; Table 22), but NAWQA fish tissue data were not available for comparison. Compared to Stations 63 and 64, greater numbers of regulated and reporting facilities were situated around the El Paso site (Appendix Table 1). Previous studies had indicated that sediment toxicity and a large number of contaminants in water, fish tissue, and sediment were of concern; that water quality was generally impaired downstream of El Paso; and that the benthic and fish communities were affected (Appendix Table 1).

\section{Middle Rio Grande and Pecos River (Stations 65, 515, and 514)}

The most evident contaminants in fish from the central parts of the RGB were As and Se (Figs. 2 and 31; Table 22); concentrations of one or both of these elements were greater than most in at least one sample from all three stations (65, PR at Red Bluff; 515, RG at Langtry; and 514, RG below Amistad Dam). $\mathrm{Hg}$ concentrations were also comparatively high in bass from Station 514 (Figs. 3 and 31; Table 22). Concentrations of Se in fish from Station 65 exceeded threshold criteria for toxicity to fish and wildlife (Table 22). The comparatively high As concentrations in fish from sites in the central parts of the RGB reflect previously documented natural sources exacerbated by irrigation activities; concentrations of both As 

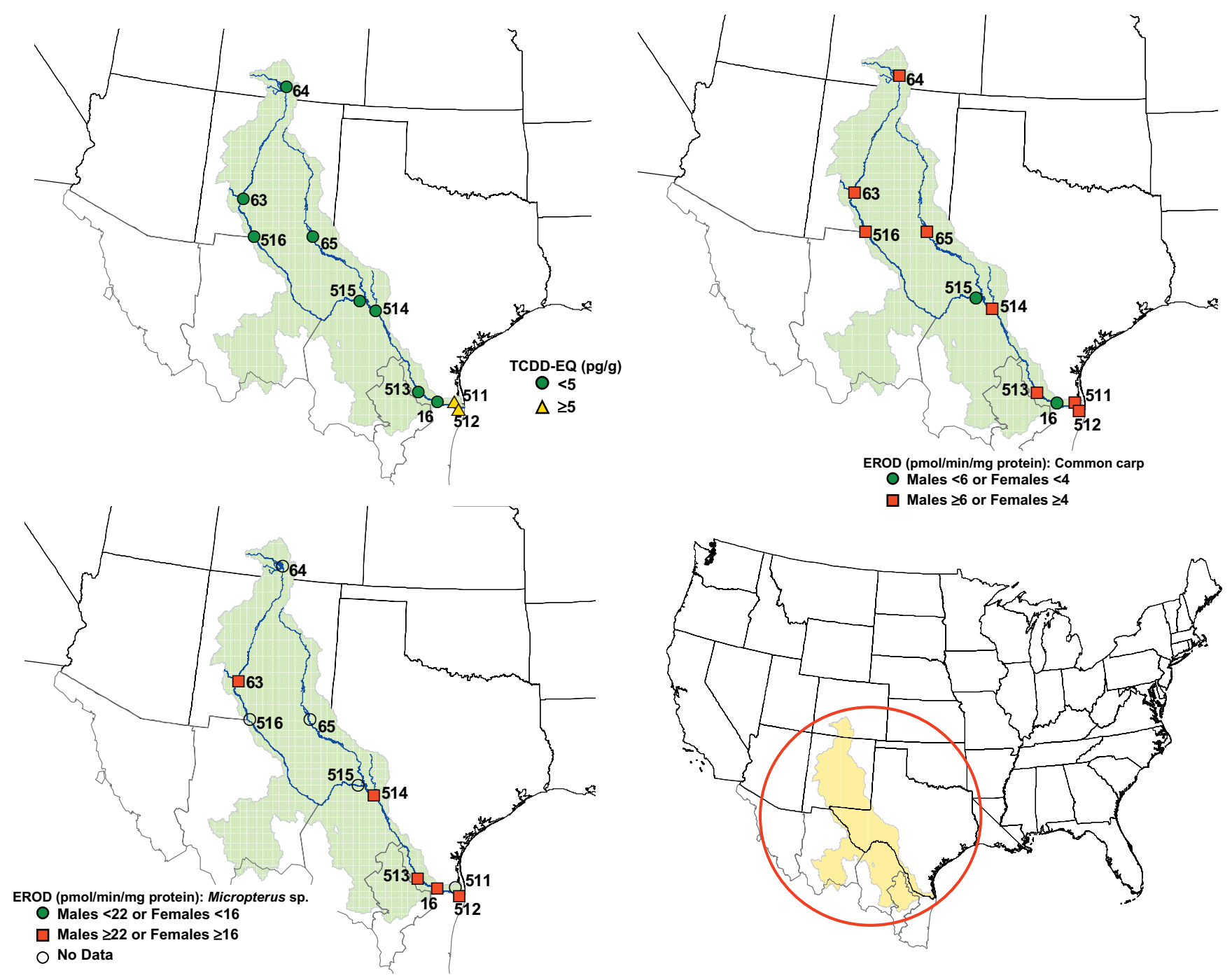

Figure 32. Maximum concentrations of TCDD-EQ in composite samples of whole fish and mean hepatic ethoxyresorufin 0-deethylase (EROD) activity ( $\mathrm{pmol} / \mathrm{min} / \mathrm{mg}$ protein) in carp and bass (Micropterus $\mathrm{sp}$.). TCDD-EO concentrations $>5 \mathrm{pg} / \mathrm{g}$ are potentially toxic to piscivorous avian and mammalian wildlife, but the threshold for toxicity to fish is about $35 \mathrm{pg} / \mathrm{g}$. For EROD activity, the thresholds indicated are levels identified in previous studies as indicative of exposure to exogenous Ah-R agonists (Schmitt and others, 2002c). See Table 1 for station descriptions and collection dates.

and Se were lower than in the past, however. The fish health biomarkers from the three central RGB sites were largely unremarkable; the only noteworthy findings were comparatively low CF in carp at Station 65 (Fig. 13), relatively large spleen size (SSI) in bass from Station 514 (Fig. 15), and a greater than average percentage of the fish from Station 515 (carp only) with external lesions, the latter also reflected in elevated HAI (Fig. 12; Tables 19 and 22). In contrast, reproductive biomarker anomalies were apparent in female bass from Station 514; however, these were all associated with a microsporidian parasite infection in the ovaries (Fig. 26). Station 514 was the only RGB site of the four from which male bass gonads were obtained where ovotestis was not detected, but the sample size was small $(n=3$; Fig. 33). Little extant information was available for comparison with 1997 findings for Station 65. In the past, NCBP fish from this site contained comparatively high concentrations of As and Se (Schmitt and other, 1999b), as they did in 1997.

In contrast to Station 65, the RG below El Paso has been heavily investigated. Earlier studies by the TNRCC (1994b; Davis and others, 1995) identified As, Hg, Cd, DDE, and HCB in sediments as contaminants of concern from Presidio downstream to Amistad Dam, as were $\mathrm{Se}, \mathrm{Hg}$, and other metals in fish (Appendix Table 1). Additional data for Stations 514 and 515 were available from NASQAN, which detected watersoluble pesticides and trace elements in water during 1995-97 at both sites; however, water quality criteria were not exceeded (Appendix Table 1). Previous studies also noted concentrations of several metals, As, Se, and DDT in fish as contaminants of concern in this reach. 


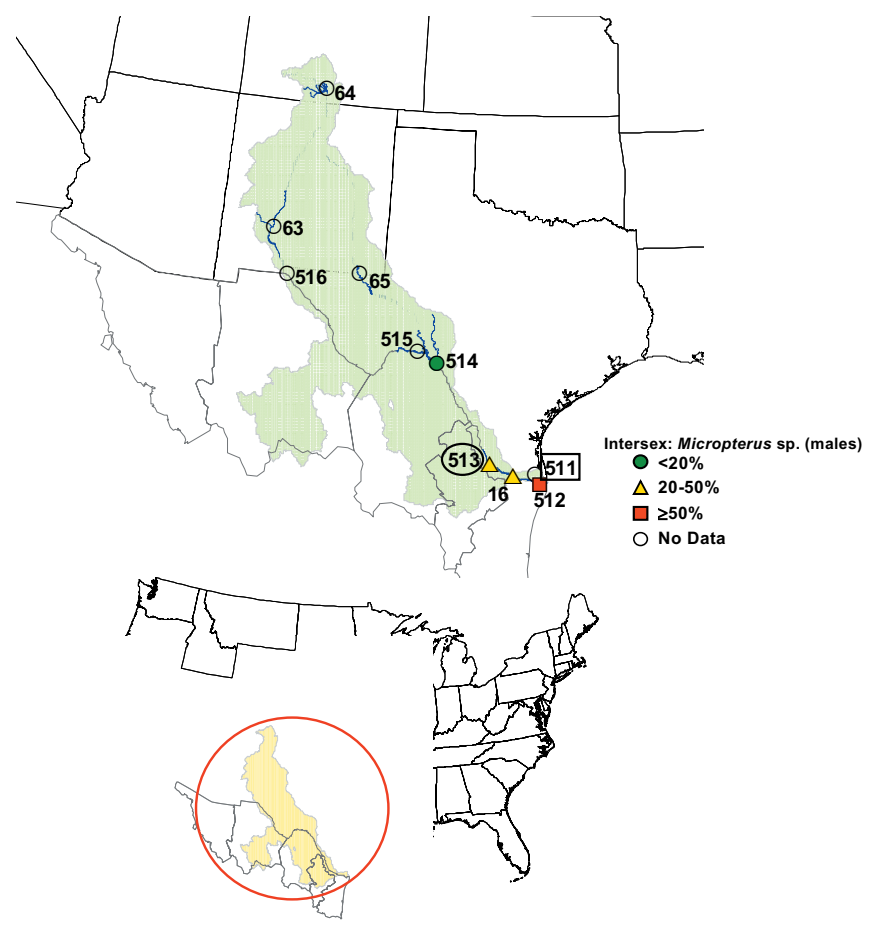

Figure 33. Percentages of male bass from the indicated stations in which ovotestis was detected through histopathological examination of the gonads. See Table 1 for station descriptions and collection dates.

\section{Lower Rio Grande and Arroyo Colorado (Stations $16,511,512$, and 513 )}

Greatest organochlorine chemical burdens and prevalence of anomalous biomarkers occurred in the lower RGB (Figs. 7, 9, 10, 30, and 32; Table 22). Some samples also contained high concentrations of metals (Table 22). Female bass from Station 513 (RG at Amistad) contained particularly high concentrations of $\mathrm{Cr}$ and $\mathrm{Ni}$ (Fig. 5), and EROD rates in bass were elevated (Figs. 10 and 32). Concentrations of PCBs and TCDD-EQ in fish from this site were low (Fig. 9); the elevated EROD rates may therefore have resulted from exposure to PAH (Table 4). Plasma vtg concentrations were elevated in one male bass from Station 513, and four of nine male bass were intersex as identified by the presence of ovotestis (Fig. 33; Table 22). In addition, HAI was elevated in both carp and bass from Station 513 (Fig. 12; Table 22). Slightly elevated concentrations of DDE characterized fish from Station 16 (RG at Mission, TX; Figs. 6, 7, and 30), and male bass from this site had elevated MA parameters (Figs. 16-18; Table 22). In addition, the $\mathrm{Pb}$ concentrations in one sample (female bass) from this site was very high (Fig. 4; Table 22). Ovotestis was detected in two of the 10 male bass from Station 16 examined, but vtg concentrations were low in all male fish and all other biomarkers were unremarkable (Fig. 33). Fish from Station 511 (AC at Harlingen) contained elevated concentrations of several organochlorine pesticides (Figs. 7 and 30) and EROD activity was elevated (Figs. 10 and 32; Table 22), indicating exposure to exogenous AhR ligands. The lack of PCBs and low levels of TCDD-EQ (Figs. 9 and 32) suggest exposure to PAH. HAI scores in carp from this site were elevated (Fig. 12) and elevated plasma vtg was detected in one male carp (Fig. 33; Table 22). Fish from Station 511 were collected earlier than at other sites in the lower RGB and were in correspondingly less advance gonadal stages (Fig. 21; Table 1). Fish from Station 512 (RG at Brownsville) contained slightly elevated concentrations of As, Ni, and TCDD-EQ (Figs. 2, 9, and 31), and EROD activity indicated exposure to exogenous AhR ligands (Figs. 10 and 32; Table 22). Several fish health biomarkers (CF, HAI, MA) were also consistent with exposure to contaminants at Station 512 (Table 22). In addition, ovotestis was detected in four of the eight male bass examined, but no male carp or bass from Station 512 contained high concentrations of vtg (Fig. 33). A comparatively large percentage of atretic eggs were also present in the ovaries of the female carp collected from Station 512, however (Fig. 25; Table 22).

The 1997 findings corroborated those of many other programs and studies indicating that the lower RGB is contaminated to the extent that fish and wildlife may be at risk. Historically, NCBP fish from Station 16 contained high organochlorine chemical concentrations relative to those from Stations 63, 64, and 65 (Schmitt and others, 1999b). NASQAN data for the lower RGB also revealed the presence of atrazine, malathion, and chlorpyrifos in water; at Station $511,90^{\text {th }}$ percentile concentrations for atrazine and chlorpyrifos exceeded water quality criteria for the protection of aquatic life during the period preceding the collection of the fish, and the $90^{\text {th }}$ percentile concentration of malathion was $84 \%$ of the criterion value (Appendix Table 1). An existing advisory for the AC (including Station 511) recommends that no fish be consumed due to contamination by DDE, chlordanes, and toxaphene (Appendix Table 1). Earlier studies by USEPA (1992b) also indicated than fish from the AC at Harlingen were contaminated with organochlorine chemical residues. River segments identified by TNRCC (1994a; 1994b) with contaminant concentrations in water 'of possible concern' and sediment and fish tissue contaminant concentrations exceeding screening levels included: Falcon International Reservoir to the head of the tidal reach $(\mathrm{Hg}, \mathrm{Pb}$, and chlordane in water); below Falcon Dam (DDE in sediment); RG tidal (DDE in sediment, $\mathrm{PCBs}$ in fish); and the $\mathrm{AC}$ above tidal (Se and DDE in sediment; toxaphene, dieldrin, and $\mathrm{Pb}$ in fish). Another recent TNRCC study (Davis and others, 1995) found that Se concentrations in water and $\mathrm{Hg}, \mathrm{Se}$, and chlordane concentrations in fish exceeded screening levels at Brownsville. Contamination was more evident at the Port of Harlingen, where screening levels were exceeded for Se in water, DDE in sediment, and $\mathrm{Hg}$, Se, chlordane, total DDT, and $\gamma-\mathrm{HCH}$ in fish (Davis and others, 1995). As a result, Brownsville was rated as having a 
slight potential for toxic chemical impact whereas Harlingen was rated with a moderate potential (Davis and others, 1995). Brownsville and Harlingen were also identified by Mora and Wainwright (1997) because of organic chemical residues in fish during the period of record (1960s-1980s). The residues included organochlorine pesticides, $\mathrm{PCBs}$, $\mathrm{PAH}$, phthalates, and phenolic compounds. In the past, concentrations of DDE were considered elevated near the Port of Harlingen (Mora and Wainwright, 1998) and $\mathrm{Hg}$ contamination was reported near Station 16 (TNRCC, 1994a) and Harlingen (Davis and others, 1995). Searches of online databases located fewer mines in the lower RGB than upstream; however, there were more landfills and TRI, NPDES, CERCLIS, and TNRCC Superfund sites (Appendix Table 1).

Overall, it is important to note that although the lower RGB was contaminated relative to other RG sites investigated, contaminant concentrations have declined greatly over the last two decades. Although still high enough to represent a threat to human and wildlife fish consumers, maximum 1997 concentrations of residues derived from DDT were 20-fold lower than those reported in the late 1970s. Concentrations of other obsolete pesticides have also declined. These trends and most of the biomarker responses noted for the lower RGB were similar to those found in the southernmost parts of the MRB investigated during 1995 (Schmitt, 2002a).

\section{Correlations Between Contaminant Concentrations and Biological Endpoints}

Rank correlations between selected biological endpoints (fish size and age; biomarkers) and contaminant concentrations in fish indicated statistically significant relations between many pairs of variables (Table 23). Correlation coefficients ranged from marginally $(P=0.10)$ to highly $(P<0.001)$ significant, and most statistically significant correlations were consistent across taxa and genders. That is, nearly all significantly correlated pairs varied in the same direction (positive or negative) irrespective of species and gender (Table 23).

Concentrations of several contaminants were correlated with fish size (Table 23). Although there was some variation, $p, p$ '-DDE and $\mathrm{Se}$ in carp and $\mathrm{Hg}$ in bass tended to increase with fish size, age, or both whereas concentrations of TCDD$\mathrm{EQ}, \mathrm{Cu}$, and Ni tended to decline (Table 23). Among biomarkers, EROD was positively correlated with chlordane in carp and catfish, TCDD-EQ and $\mathrm{Cr}$ in carp, $\mathrm{Zn}$ in male bass, and with As in all taxa (Table 23). In contrast, EROD was negatively correlated with $\mathrm{Cu}$ in all taxa, DDE and Se in bass, and $\mathrm{Cd}$ in female carp. SSI was negatively correlated with many contaminants and positively correlated with only $\mathrm{Cu}$ in female carp and $\mathrm{Zn}$ in catfish (Table 23). HSI, which was not analyzed in carp, was positively correlated with DDE, TCDD$\mathrm{EQ}, \mathrm{Cr}, \mathrm{Cu}$, and $\mathrm{Hg}$ in bass of either or both genders, but was negatively correlated with $\mathrm{Cd}$ in catfish and $\mathrm{Pb}$ in female bass.
The MA parameters were variably correlated with a number of contaminants, some consistently and some not (Table 23). Negative relationships were documented between the MA variables and concentrations of $\mathrm{As}, \mathrm{Cu}$, and Se whereas correlations with TCDD-EQ, Cd, Cr, Hg, Ni, and $\mathrm{Zn}$ were positive and others were neutral or varied in direction and strength. Although HAI and external lesions are functionally related variables, they were correlated with difference contaminants (Table 23). HAI was positively related to DDE, $\mathrm{Cr}, \mathrm{Hg}, \mathrm{Pb}$, and $\mathrm{Se}$ in all taxon-gender combinations and both positively and negatively correlated in others. Significant correlations with external lesions were universally positive for TCDD-EQ, $\mathrm{Cd}, \mathrm{Cu}$, and $\mathrm{Zn}$ and universally negative for $\mathrm{Pb}$ (Table 23).

Among the reproductive biomarkers, GSI was negatively correlated with DDE, chlordane, $\mathrm{As}$, and $\mathrm{Pb}$ in catfish, but correlations with $\mathrm{Cu}, \mathrm{Ni}$, and $\mathrm{Zn}$ in catfish were positive (Table 23). Overall, correlations between GSI and contaminants were highly variable in direction and magnitude and, in contrast to the findings of Wainwright and others (2001), GSI was not significantly correlated with DDE in male carp (Table 23). Atresia was correlated with relatively few variables, but all correlations were positive; atresia was correlated with DDE and Se in carp and with $\mathrm{Hg}$ in bass (Table 23). Stage was negatively correlated with chlordane and $\mathrm{Zn}$ in carp and bass and with $\mathrm{Pb}$ in male carp; however, stage was positively correlated with $\mathrm{Cu}$ in both male and female bass and with $\mathrm{Hg}$ in female carp (Table 23). Ceroid pigment scores were positively correlated with DDE in male bass and in carp, with chlordane and $\mathrm{Cr}$ in female carp, with $\mathrm{Hg}$ in female and all bass, and with $\mathrm{Zn}$ in all carp (Table 23). In contrast, ceroid pigment was negatively correlated with chlordane in female bass, As in male carp, $\mathrm{Cu}$ in male bass and female carp, $\mathrm{Pb}$ in female bass, and Se in male bass. Vtg concentrations (female carp and bass only) were positively correlated with $\mathrm{Cd}$ in carp and bass and with $\mathrm{Cu}$ in carp, but were negatively correlated with As in bass (Table 23).

Many of the statistically significant correlations confirmed observations already made about the data; for example, HAI, HSI, atresia, and ceroid pigment scores increased with $p, p$ '-DDE concentrations, reflecting the generally poorer overall health of fish from the lowermost parts of the RG, where pesticide residue concentrations were greatest. Concentrations of several contaminants, most notably DDE and $\mathrm{Hg}$, also tended to increase with size, however, indicating that some of the association between these contaminants and biomarkers may be related to fish size or age differences between the sites. Some correlations were also counter-intuitive; that is, they were the opposite of what was anticipated based on extant knowledge of the biomarkers. Although there may be many explanations for these fidnings, they may represent relations that have not been documented in laboratory studies. Such counter-intuitive results are common in post-hoc analyses, especially where the range of contaminant concentrations is narrow, as was true for most analytes in the RGB. In addition, the sample sizes were small ( $n=6$ for catfish and within-gender analyses of bass and carp). For these reasons, and as noted 


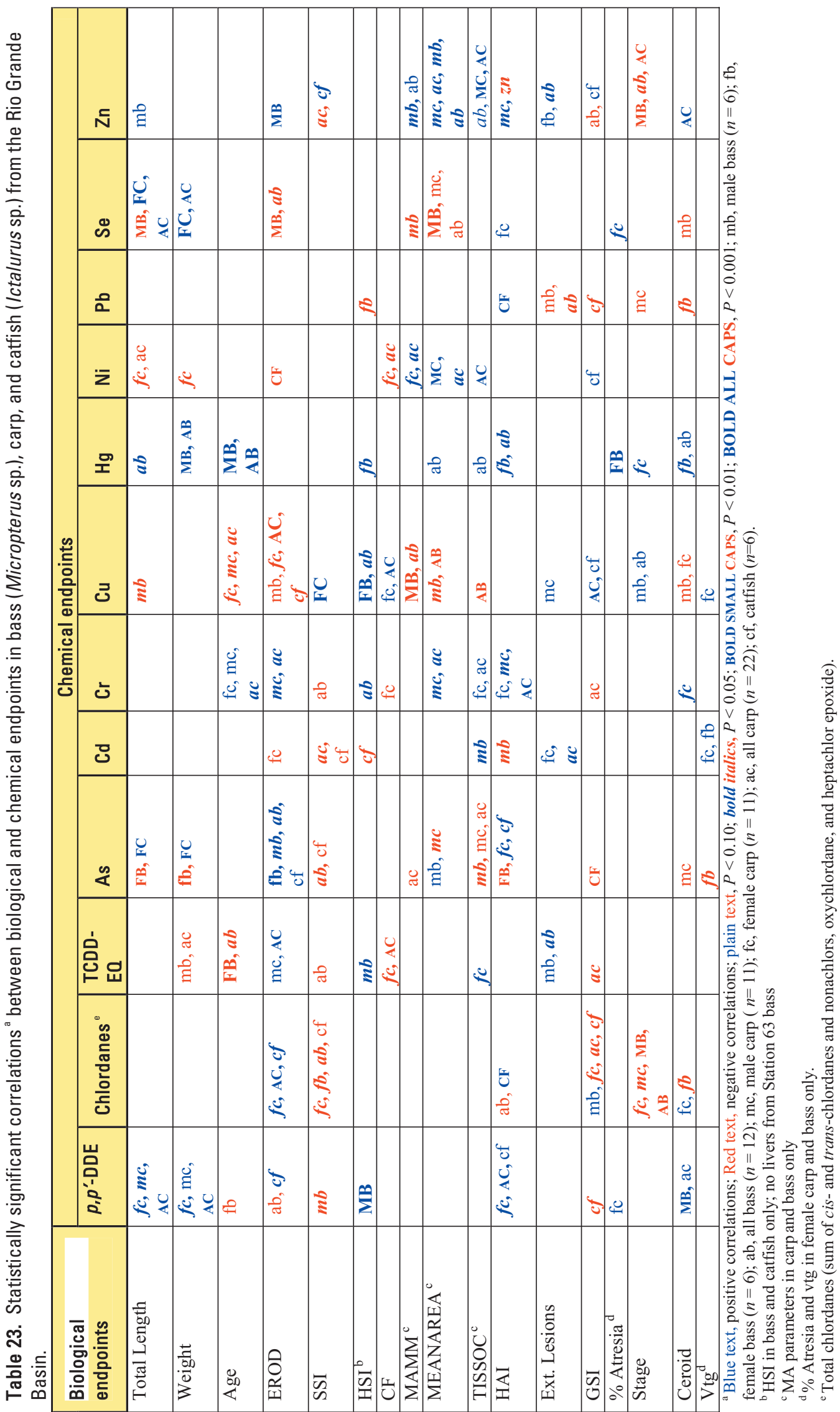


in the report summarizing the 1995 MRB study (Schmitt, 2002a), simple correlations between pairs of variables should only be considered a first step in an exploratory statistical analysis. Subsequent analyses using more robust methods focused on the 1997 data combined with that from other studies should seek to better define relations between contaminants and biomarkers. These analyses should also incorporate data characterizing contaminant concentrations in water and sediment, such as the data from NAWQA and NASQAN.

\section{Summary and Conclusions}

Overall, fish from stations in the lower RGB contained greater concentrations of contaminants and appeared to be less healthy than those from sites in the central and upper parts of the basin. As noted by other studies, and with the exceptions indicated, there was a general gradient of concentrations and biomarker responses from upstream to downstream. In the upper parts of the basin, a minimal number of altered biomarkers and few or no elevated contaminant concentration were noted. The exception in the upper basin was elevated concentrations of $\mathrm{Hg}$ (up to $0.46 \mu \mathrm{g} / \mathrm{g}$ ) in predatory fishes from Station 63 (Elephant Butte Reservoir), a condition noted in the past and for which a consumption advisory remains in effect.

Elemental contaminants were also prevalent in fish from the central RGB sites. Fish from Station 514 (Amistad International Reservoir) contained slightly elevated concentrations of Se (1.1-1.5 $\mu \mathrm{g} / \mathrm{g})$ and were characterized by comparatively high organosomatic indices, proportion of fish with external lesions, and HAI scores. In addition, bass from Station 514 contained elevated concentrations of $\mathrm{Hg}$ (up to $0.40 \mu \mathrm{g} / \mathrm{g}$ ). Se concentrations were also elevated at Stations 65 (up to $1.9 \mu \mathrm{g}$ / $\mathrm{g}$ in white bass) and 515 (>1.0 $\mu \mathrm{g} / \mathrm{g}$ in carp). A comparatively large percentage of the carp from Station 515 had high HAI scores caused primarily by the presence of parasite-induced external lesions; and some samples from Stations 65 and 514 contained comparatively high concentrations of As $(>0.3$ $\mu \mathrm{g} / \mathrm{g})$. Concentrations of As and Se in fish from Station 65 were lower than in the past, but Se concentrations at this site as well as others in the central RGB were sufficiently high to represent a threat to fish and wildlife.

In the lower RGB, organochlorine pesticide residues were evident in fish from most sites, and concentrations exceeded toxicity thresholds for fish and wildlife at Stations 16, 511, and 512. At Station 513, concentrations of DDE and Se were high relative to other sites and at Station 511 (AC at Harlingen) organochlorine concentrations were similar to those found in fish from the cotton-growing regions of the MRB sampled in 1995 (Schmitt and others, 2002c); a consumption advisory is in effect for the AC and nearby waters because of DDE, chlordane, and toxaphene contamination. Although high by contemporary standards, residue concentrations were nevertheless lower than those reported in the past, indicating the continued weathering of obsolete pesticides. This conclusion was further supported by the lack of $p, p$ '-DDT and the increasing proportions of $p, p$ '-DDE in 1997 samples relative to the past, both of which indicate the weathering of old material rather than the influx of new pesticides. However, concentrations of $\mathrm{cis}$-chlordane remained high relative to those of trans-nonachlor and other chlordane components at Station 511, indicating more recent inputs of these compounds. Slightly elevated HAI values characterized carp from Station 511 and a comparatively high frequency of external lesions was noted on bass at Station 512; histopathological examination revealed the latter to be parasite-induced. Comparatively high individual HAI values were also recorded at Stations 16,512 , and 513, and one or more macrophage aggregate parameters were elevated in carp, bass, or both at all lower RGB stations. Histopathological examination of liver, spleen, and kidney tissues of fish from the lower RGB sites revealed conditions that are consistent with contaminant exposure. The reproductive biomarkers also suggested that fish from the lower RGB sites had been exposed to contaminants; intersex male bass, relatively low GSI, and elevated vtg concentrations in male fish were noted at three of the four stations, and large percentages of atretic eggs were present in female carp from Station 512.

Concentrations of PCBs and TCDD-EQ were comparatively low in most RGB samples, but EROD rates in at least some carp, bass, channel catfish, or multiple species were indicative of exposure to exogenous AhR ligands at all sites. Collectively, and as suggested by the information in Table 4, these findings suggest that fish from most RGB sites had been exposed to PAH, which is consistent with the widespread energy extraction and transportation activities that occur throughout much of the basin. Some PAH are highly toxic at relatively low concentrations; however it is also important to note that although elevated relative to basal activity in the species investigated, EROD rates in RGB fish were generally low relative to those reported for these species from other locations (Schmitt and others, 2002c; Whyte and others, 2000).

Overall, and as reported for the MRB (Schmitt and others, 1999b) we saw no evidence indicating that fish in the RGB had been exposed to extremely high concentrations of toxic chemicals. Rather, and as reported for some MRB sites sampled in 1995 (Schmitt, 2002a), the biomarker data for the lower basin stations are consistent with subtle responses to contaminants. In addition, EROD rates were slightly elevated at most sites. Absent elevated PCB residues and TCDD-EQ, these EROD rates indicate that the fish were exposed to PAHs (Whyte and others, 2000). Previous studies (Davis and others, 1995; TNRCC, 1997) indicated the potential for toxic chemical impacts on biota in the AC at Harlingen and in the RG at Brownsville. The USFWS also recognized contaminants 
from agriculture and energy extraction as threats to Laguna Atascosa NWR and other refuges in the lower RGB (USFWS, 1986). Our findings for sites in the lower RGB support these conclusions and concerns; concentrations of several organochlorine and elemental contaminants were great enough to represent a potential hazard to populations of the most sensitive fish-eating wildlife species. In addition, the human population of the RGB is growing rapidly, which will expand both the magnitude and scope of potential contaminant threats in the region and the demand for increasingly limited amounts of water. Although our data and that from other programs, including NCBP, have documented declining concentrations of persistent organochlorine chemical residues and of As and Se at one site, the continuing growth of irrigated agriculture in the RGB may further exacerbate the leaching of these elements into ground and surface waters. Concentrations of $\mathrm{Hg}$ remain at potentially problematic concentrations in the mainstem impoundments, which are inhabited by susceptible DOI trust species including the bald eagle and the interior least tern. Contemporary-use agricultural pesticides such as atrazine, chlorpyrifos, and diazinon were also detected at potentially problematic concentrations at some sites in the lower RGB by other programs. Although concentrations of only a few of these compounds exceeded current standards and criteria, levels may rise in the future due to changing agricultural practices and declining water availability. In addition, subtle responses to these and other chemicals may occur at concentrations lower than current standards, and their cumulative effects are largely unknown (McDonald and others, 2000; Scholz and others, 2000). Overall, results from the suite of biological endpoints measured were consistent with exposure to chemicals at the lower basin sites. These responses would also be expected to increase in magnitude with increasing pesticide concentrations, which might ultimately threaten fish populations.

Mora and Wainwright (1998) urged further monitoring of the RGB due to limited historical data, increasing development, and a dearth of information on activities and contaminant releases in northern Mexico. Our findings also support this recommendation. Continued monitoring provides the basis for identifying consistently degraded sites as well as those with emerging problems, and for evaluating the success of remedial activities. Focused investigations are also necessary to document chemical sources and processes, cause-effect relationships, and possible roles of factors other than contaminants.

\section{References}

Ackerman, G.E., Brombacher, E., and Fent, K., 2002, Development of a fish reporter gene system for the assessment of estrogenic compounds and sewage treatment plant effluents: Environmental Toxicology and Chemistry, v. 21, no. 9, p. 1864-1875.

Adams, S.M., 1990, Status and use of biological indicators for evaluating the effects of stress on fish, in Adams, S.M., ed., Biological indicators of stress in fish. American Fisheries Society Symposium 8: Bethesda, MD, AFS, p. 1-8.

Adams, S.M., Brown, A.M., and Goede, R.W., 1993, A quantitative health assessment index for rapid evaluation of fish condition in the field: Transactions of the American Fisheries Society, v. 122, p. 63-73.

Adams, S.M., Ham, K.D., and Beauchamp, J.J., 1994, Application of canonical variate analysis in the evaluation and presentation of multivariate biological response data: Environmental Toxicology and Chemistry, v. 13, no. 10, p. 1673-1683.

Adams, S.M., and McLean, R.B., 1985, Estimation of largemouth bass, Micropterus salmoides Lacepede, growth using the liver somatic index and physiological variables: Journal of Fish Biology, v. 26, p. 111-126.

Agius, C., 1980, Phylogenetic development of melano-macrophage centres in fish: Journal of Zoology, v. 191, p. 11-31.

Aguillar, A., 1984, Relationships of DDE/DDT in marine mammals to the chronology of DDT input into the ecosystem: Canadian Journal of Fisheries and Aquatic Sciences, v. 21, p. 840-844.

Allen, Y., Scott, A.P., Matthiessen, P., Haworth, S., Thain, J.E., and Feist, S., 1999, Survey of estrogenic activity in United Kingdom estuarine and coastal waters and its effects on gonadal development of the flounder Platichthys flesus: Environmental Toxicology and Chemistry, v. 18, p. 17911800 .

Anderson, D.W., Jehl, J.R., Jr., Risebrough, R.W., Woods, L.A., Jr., DeWeese, L.R., and Edgecomb, W.G., 1975, Brown pelicans: improved reproduction off the southern California coast: Science, v. 190, p. 806-808.

Ankley, G., Tillitt, D., Giesy, J., Jones, P., and Verbrugge, D., 1991, Bioassay-derived 2,3,7,8-tetrachlorodibenzo- $p$-dioxin equivalents in PCB-containing extracts from the flesh and eggs of Lake Michigan chinook salmon (Oncorhynchus tshawytscha) and possible implications for reproduction: Canadian Journal of Fisheries and Aquatic Sciences, v. 48, no. 9 , p. $1685-1690$. 
Bäckström, J., 1969, Distribution studies of mercuric pesticides in quail and some freshwater fishes: Acta Pharmacologica Et Toxicologica, v. 27 (Suppl 3), p. 1-103.

Bahnick, D., Sauer, C., Butterworth, B., and Kuehl, D.W., 1994, A national study of mercury contamination of fish. IV: analytical methods and results: Chemosphere, v. 29, no. 3, p. 537-546.

Bailey, R.G., 1995, Descriptions of the ecoregions of the United States, 2nd edition: U.S. Department of Agriculture, Forest Service, Miscellaneous Publication nr 1391.

Baldigo, B., Sloane, R.J., Smith, S.B., and Keane, D.P., 2001, Polychlorinated biphenyls and endocrine disruption in fish from the Hudson River, New York, USA (poster): http:// ny.water.usgs.gov/pubs/posters/pcbendocrine.pdf.

Barr, J.F., 1986, Population dynamics of the common loon (Gavia immer) associated with mercury-contaminated waters in northwestern Ontario: Canadian Wildlife Service, Occasional Paper 56.

Baumann, P.C., and Gillespie, R.B., 1986, Selenium bioaccumulation in gonads of largemouth bass and bluegill from three power plant cooling reservoirs: Environmental Toxicology and Chemistry, v. 5, p. 695-701.

Bidleman, T.F., Wall, M.D., Muir, D.C.G., and Stern, G.A., 1993, Selective accumulation of polychlorocamphenes in aquatic biota from the Canadian arctic: Environmental Toxicology and Chemistry, v. 12, no. 4, p. 701-710.

Birke, S.R., and Tillitt, D.E., 2000a, Determination of 2,3,7,8Tetrachlorodizenzo- $p$-dioxin equivalents (TCDD-EQ) with the H4IIE bioassay on fish tissue samples collected from the Columbia and Lower Rio Grande river basins as part of the 1997 Biomonitoring of Environmental Status and Trends (BEST) program: U.S. Geological Survey, Biochemistry and Physiology Branch Report (unpublished report).

2000 b, Determination of enzymatic activity of cytochrome P450IAI in fish collected from the Columbia and Lower Rio Grande river basins as part of the 1997 Biomonitoring of Environmental Status and Trends (BEST) Program: U.S. Geological Survey, Biochemistry and Physiology Branch Report (unpublished report).

Blazer, V.S., 2002, Histopathological assessment of gonadal tissue in wild fishes: Fish Physiology and Biochemistry, v. 26, p. 85-101.

Blazer, V.S., and Dethloff, G.M., 2000, Immune system indicators, in Schmitt, C.J. and Dethloff, G.M. eds., Biomonitoring of Environmental Status and Trends (BEST) Program: selected methods for monitoring chemical contaminants in aquatic ecosystems: U.S. Geological Survey, Biological Resources Division, Information and Technology Report 2000-0005, 25-30.
Blazer, V.S., Facey, D.E., Fournie, J.W., Courtney, L.A., and Summers, J.K., 1994, Macrophage aggregates as indicators of environmental stress, in Stolen, J.S., and Fletcher, T.C., eds., Modulators of fish immune responses: volume one, models for environmental toxicology, biomarkers, immunostimulators: Fair Haven, NJ, SOS Publications, p. 169-185.

Blazer, V.S., Dethloff, G.M., and Wright, B., 2002, Fish health indicators, in: Schmitt, C.J. editor, Biomonitoring of Environmental Status and Trends (BEST) Program: environmental contmainants and their effects on fish in the Mississippi River basin: U.S. Geological Survey, Biological Resources Division, Biological Science Report 2002-0004, p. 89-134.

Blazer, V.S., Fournie, J.W., and Weeks-Perkins, B.A., 1997, Macrophage aggregates: biomarker for immune function in fishes?, in Dwyer, F.J., Doane, T.R., and Hinman, M.L. eds., Environmental toxicology and risk assessment: modeling and risk assessment, vol 6: American Society for Testing and Materials, ASTM Special Technical Publication 1317.

Blus, L.J., 1996, DDT, DDD, and DDE in birds, in Beyer, W.N., Heinz, G.H., and Redmon-Norwood, A.W., eds., Environmental contaminants in wildlife: interpreting tissue concentrations: Boca Raton, FL, Lewis Publishers, p. 49-71.

Bogan, M.A., 1998, Changing landscapes of the Middle Rio Grande, in: Mac, M.J., Opler, P.A., Puckett Haecker, C.E., and Doran P. D. eds., Status and trends of the nation's biological resources. volume 2: U.S. Department of the Interior, U.S. Geological Survey, p. 562-563.

Bowman, C.J., Kroll, K.J., Gross, T.G., and Denslow, N.D., 2002, Estradiol-induced gene espression in largemouth bass (Micropterus salmoides): Molecular and Cellular Endocrinology, v. 196, p. 67-77.

Brumbaugh, W.G., Krabbenhoft, D.P., Helsel, D.R., Wiener, J.G., and Echols, K.R., 2001, A national pilot study of mercury contamination of aquatic ecosystems along multiple gradients: bioaccumulation in fish: U.S. Geological Survey, Biological Science Report 2001-0009, 25 p.

Butte, W., Fox, K., and Zauke, G.-P., 1991, Kenetics of bioaccumulation and clearance of isomeric hexachloryclohexanes: Science of the Total Environment, v. 109-110, p. 377-382.

Cabana, G., Tremblay, A., Kalff, J., and Rasmussen, J.B., 1994, Pelagic food chain structure in Ontario lakes: a determinant of mercury levels in lake trout (Salvelinus namaycush): Canadian Journal of Fisheries and Aquatic Sciences, v. 51, p. 381-389.

Caldwell, C.A., Arnold, M.A., and Gould, W.R., 1999, Mercury distribution in blood, tissues, and feathers of doublecrested cormorant nestlings from arid-lands reservoirs in south central New Mexico: Archives of Environmental Contamination and Toxicology, v. 36, p. 456-461. 
Canavan, C.M., Caldwell, C.A., and Bloom, N.S., 2000, Discharge of methylmercury-enriched hypolimnetic water from a stratified reservoir: The Science of the Total Environment, v. 260 , p. $159-170$.

Carlander, K.D., 1969, Handbook of freshwater fishery biology, volume 1: Ames, IA, Iowa State University Press 752 p.

1977, Handbook of freshwater fishery biology, volume 2: Ames, IA, Iowa State University Press 431 p.

Carter, L.F., and Anderholm, S.K., 1997, Water-quality assessment of the Rio Grande Valley, Colorado, New Mexico, and Texas--organic compounds and trace elements in bed sediment and fish tissue, 1992-1993: U.S. Geological Survey, Water-Resources Investigations Report nr 97-4002, 23 p.

Carter, L.F., and Porter, S.D., 1997, Trace-element accumulation by Hygrohypnum ochraceum in the upper Rio Grande Basin, Colorado and New Mexico: Environmental Toxicology and Chemistry, v. 16, no. 12, p. 2521-2528.

Chapman, D.C., Papoulias, D.M., and Onuf, C.P., 1998, Environmental change in South Texas, in Mac, M.J., Opler, P.A., Puckett Haecker, C.E., and Doran, P.D., eds., Status and trends of the nation's biological resources. volume 1 : Reston, VA, U.S. Department of the Interior, U.S. Geological Survey, p. 268-272.

Colorado Department of Public Health and Environment (CDPHE), Water Quality Control Division, 2002: http://www.cdphe.state.co.us/op/wqcc/OtherRegs/93-94/ RMH9394EX1.pdf.

Coughlan, D.J., Baker, B.K., Cloutman, D.G., and Rash, W.M., 1996, Application and modification of the fish health assessment index used for largemouth bass in the Catawba River, North Carolina-South Carolina, in Miranda, L.E., and DeVries, D.R., eds., National Reservoir Fisheries Symposium-Multidimensional Approaches to Reservoir Fisheries Management, Chattanooga, TN, Bethesda, MD, American Fisheries Society, p. 73-84.

Coyle, J.J., Buckler, D.R., Ingersoll, C.G., Fairchild, J.F., and May, T.W., 1993, Effect of dietary selenium on the reproductive success of bluegills (Lepomis macrochirus): Environmental Toxicology and Chemistry, v. 12, no. 3, p. 551-565.

Cross, J.N., and Hose, J.E., 1988, Evidence for impaired reproduction in white croaker (Genyonemus lineatus) from contaminated areas off southern California: Marine Environmental Research, v. 24, p. 185-188.

Cuvin-Aralar, M.L.A., and Furness, R.W., 1991, Mercury and selenium interaction: a review: Ecotoxicology and Environmental Safety, v. 21, p. 348-364.
Davis, J.R., Kleinsasser, L., and Cantu, R., 1995, Toxic contaminants survey of the Lower Rio Grande, lower Arroyo Colorado, and associated coastal waters: Texas Natural Resource Conservation Commission.

Denslow, N.D., Chow, M.C., Kroll, K.J., and Green, L., 1999, Vitellogenin as a biomarker of exposure for estrogen or estrogen mimics: Ecotoxicology, v. 8, p. 385-398.

Dethloff, G.M., and Schmitt, C.J., 2000, Condition factor and organo-somatic indices, in Schmitt, C.J. and Dethloff, G.M. eds., Biomonitoring of Environmental Status and Trends (BEST) Program: selected methods for monitoring chemical contaminants in aquatic ecosystems: U.S.Geological Survey, Biological Resources Division, Information and Technology Report nr 2000-0005, p. 13-17.

Dwyer, F.J., Schmitt, C.J., Finger, S.E., and Mehrle, P.M., 1988, Biochemical changes in longear sunfish, Lepomis megalotis, associated with lead, cadmium and zinc from mine tailings: Journal of Fish Biology, v. 33, p. 307-317.

Eargle, D.H., and Kleiner, D.J., 2002, Handbook of Texas online: Uranium mining: http://www.tsha.utexas.edu/handbook/online/.

Eichers, T.R., Andrilenus, P.A., and Anderson, T.W., 1978, Farmers' use of pesticides in 1976: U.S. Department of Agriculture, Economics, Statistics, and Cooperatives Service, Agricultural Economic Report nr 418, 58 p.

Eisler, R., 1985, Cadmium hazards to fish, wildlife, and invertebrates: a synoptic review: U.S. Fish and Wildlife Service, Biological Report, Contaminant Hazard Reviews 85(1.2), $35 \mathrm{p}$.

1986, Chromium hazards to fish, wildlife, and invertebrates: a synoptic review: U.S. Fish and Wildlife Service, Biological Report 85(1.6), $60 \mathrm{p}$.

1987, Mercury hazards to fish, wildlife, and invertebrates: a synoptic review: U.S. Fish and Wildlife Service, Biological Report 85(1.10), 90 p.

1990, Chlordane hazards to fish, wildlife, and invertebrates: a synoptic review: U.S. Fish and Wildlife Service, Biological Report, Contaminant Hazard Reviews 85(1.21), $49 \mathrm{p}$.

1993, Zinc hazards to fish, wildlife, and invertebrates: a synoptic review: U.S. Fish and Wildlife Service, Biological Report, Contaminant Hazard Reviews nr 85(1.26), 106 p.

1997, Copper hazards to fish, wildlife, and invertebrates: a synoptic review: U.S. Fish and Wildlife Service, Biological Report 10, 106 p.

Eisler, R., and Jacknow, J., 1985, Toxaphene hazards to fish, wildlife, and invertebrates: a synoptic review: U.S. Fish and Wildlife Service, Biological Report 85(1.4), 26 p. 
El-Hage, A., and Moulton, D.W., 1998, Evaluatin of selected natural resources in parts of Loving, Pecos, Reeves, Ward, and Winkler Counties, Texas: Texas Department of Parks and Wildlife, Resource Protection Divsion, Water Resources Team, $40 \mathrm{p}$.

Ellis, A.E., Munro, A.L.S., and Roberts, R.J., 1976, Defense mechanisms in fish. 1. A study of the phagocytic system and the fate of intraperitoneally injected particulate material in the plaice (Pleuronectes platessa L.): Journal of Fish Biology, v. 8, p. 67-78.

Ellis, S.R., Levings, G.W., Carter, L.F., Richey, S.F., and Radel, M.J., 1993, Rio Grande Valley, Colorado, New Mexico, and Texas: Water Resources Bulletin, v. 29, p. 617-646.

Environmental Health Perspectives, 1997, Mexico moves to phase out DDT and chlordane: Environmental Health Perspectives, v. 105, p. 790-791.

[EPA] Environmental Protection Agency (US), 1992a, National study of chemical residues in fish: volume I: Office of Science and Technology, Standards and Applied Science Division, Report nr EPA 823-R-92-008a .

1992b, National Study of cehmical reisdues in fish. volume II: Office of Science and Techonology, Standards and Applied Science Division, Report nr EPA 823-R-92-008b.

1999, Compilation of national recommended water quality criteria: http://www.epa.gov/waterscience/standards/ wqcriteria.html.

Farag, A.M., Stansbury, M.A., Hogstrand, C., MacConnell, E., and Bergman, H.L., 1995, The physiological impairment of free-swimming brown trout exposed to metals in the Clark Fork River, Montana: Canadian Journal of Fisheries and Aquatic Sciences, v. 52, p. 2038-2050.

Ferguson, H.W., 1976, The relationship between ellipsoids and melano-macrophage centres in the spleen of turbot (Scophthalmus maximus): Journal of Comparative Pathology, v. 86, p. 377-380.

Finney, D.J., 1980, Statistics for biologists: New York, Chapman and Hall 165 p.

Fipps, G., 1991, Irrigation drainage water quality issues in the Lower Rio Grande Valley of Texas, in: Buren, J., and Fleming, C., eds., Proceedings of IRDC-90: irrigation, research, and development in the 1990s, University of Lethbridge, Alberta, Canada, Water Resources Institute, p. 463-468.

Folmar, L.C., Denslow, N.D., Rao, V., Chow, M., Crain, D.A., Enblom, J., Marcino, J., and Guillette, L.J., Jr., 1996, Vitellogenin induction and reduced serum testosterone concentrations in feral male carp (Cyprinus carpio) captured near a major metropolitan sewage treatment plant: Environmental Health Perspectives, v. 104, no. 10, p. 1096-1101.
Folmar, L.C., Gardner, G.R., Schreibman, M.P., MagliuloCepriano, L., Mills, L.J., Zaroogian, G., Gutjahr-Gobell, R., Haebler, R., Horowitz, D.B., and Denslow, N.D., 2001, Vitellogenin-induced pathology in male summer flounder (Paralichthys dentatus): Aquatic Toxicology, v. 51, no. 4, p. 431-441.

Förlin, L., and Celander, M., 1993, Induction of cytochrome P4501A in teleosts: environmental monitoring in Swedish fresh, brackish and marine waters: Aquatic Toxicology, v. 26, p. 41-56.

Fournie, J.W., Summers, J.K., Courtney, L.A., Engle, V.D., and Blazer, V.S., 2001, Utility of splenic macrophage aggregates as an indicator of fish exposure to degraded environments: Journal of Aquatic Animal Health, v. 13, no. 2, p. 105-116.

Fournie, J.W., Summers, J.K., and Weisberg, S.B., 1996, Prevalence of gross pathological abnormalities in estuarine fishes: Transactions of the American Fisheries Society, v. 125 , no. 4, p. 581-190.

[FWS] Fish and Wildlife Service (US), 1986, Preliminary survey of contaminant issues of concern on national wildlife refuges: FWS, Division of Refuge Management, 162 p.

Gamble, L.R., Jackson, G., and Maurer, T.C., 1988, Organochlorine, trace elelment, and petroleum hydrocarbon contaminants investigation of the lower Rio Grande Valley, Texas, 1985-86: U.S. Fish and Wildlife Service, Ecological Services, Region 2, 34 p.

Ganther, H.E., 1978, Modification of methyl mercury toxicity and metabolism by selenium and vitamin E: possible mechanisms: Environmental Health Perspectives, v. 25, p. 71-76.

Ganther, H.E., Goudie, C., Sunde, M.L., Kopeck, M.J., Wagner, P., Oh, S.W., and Hoekstra, W.G., 1972, Selenium: relation to decreased toxicity of methylmercury added to diets containing tuna: Science, v. 175, p. 1122-1123.

Garcia, J.D., and Kidd, D.E., 1979, Mercury levels in water and sediment of Elephant Butte Reservoir, New Mexico: Bulletin of Environmental Contamination and Toxicology, v. 21, p. 624-630.

Giesy, J.P., Bowerman, W.W., Mora, M.A., Verbrugge, D.A., Othoudt, R.A., Newsted, J.L., Summer, C.L., Aulerich, R.J., Bursian, S.J., Ludwig, J.P., Dawson, G.A., Kubiak, T.J., Best, D.A., and Tillitt, D.E., 1995, Contaminants in fishes from Great Lakes-influenced sections and above dams of three Michigan rivers: III. Implications for health of bald eagles: Archives of Environmental Contamination and Toxicology, v. 29, p. 309-321. 
Gilderhus, P.A., 1966, Some effects of sublethal concentrations of sodium arsenate on bluegills and the aquatic environment: Transactions of the American Fisheries Society, v. 95, p. 289-296.

Gimeno, S., Komen, H., Gerritsen, A.G.M., and Bowmer, T., 1998, Feminisation of young males of the common carp, Cyprinus carpio, exposed to 4-tert -pentylphenol during sexual differentiation: Aquatic Toxicology, v. 43, p. 77-92.

Gimeno, S., Komen, H., Venderbosch, P.W.M., and Bowmer, T., 1997, Disruption of sexual differntiation in genetic male common carp (Cyprinus carpio) exposed to an alkylphenol during different life stages: Environmental Science \& Technology, v. 31, p. 2884-2890.

Gingerich, W.H., 1982, Hepatic toxicology of fishes, in Weber, L.J., ed., Aquatic toxicology: New York, NY, Raven Press, p. $55-105$.

Goede, R.W., 1988, Fish health/condition assessment procedures. Part 2 -- a color atlas of necropsy classification categories: Utah Division of Wildlife Resources, Fisheries Experiment Station.

1996, Fish health/condition assessment procedures. Part 1 -- procedures manual: Utah Division of Wildlife Resources, Fisheries Experiment Station, 31 p.

Goldstein, R.M., Brigham, M.E., and Stauffer, J.C., 1996, Comparison of mercury concentrations in liver, muscle, whole bodies, and composites of fish from the Red River of the North: Canadian Journal of Fisheries and Aquatic Sciences, v. 53, p. 244-252.

Goldstein, R.M., and DeWeese, L.R., 1999, Comparison of trace element concentrations in tissue of common carp and implications for monitoring: Journal of American Water Resources Association, v. 35, p. 1133-1140.

Gooch, J.W., and Matsamura, F., 1987, Toxicity of chlorinated bornane (toxaphene) residues isolated from Great Lakes lake trout (Salvelinus namaycush): Archives of Environmental Contamination and Toxicology, v. 16, p. 349-355.

Goodbred, S.L., Gilliom, R.J., Gross, T.S., Denslow, N.P., Bryant, W.L., and Schoeb, T.R., 1997, Reconnaissance of 17ß-estradiol, 11-ketotestosterone, vitellogenin, and gonad histopathology in common carp of United States streams: potential for contaminant-induced endocrine disruption: U.S. Geological Survey, Open-File Report nr 96-627, 47 p.

Graf, W. L., 1994, Plutonium and the Rio Grande: environmental change and contamination in the nuclear age: New York, NY, Oxford University Press, 329 p.
Grady, A.W., McLaughlin, R.M., Caldwell, C.W., Schmitt, C.J., and Stalling, D.L., 1992, Flow cytometry, morphometry and histopathology as biomarkers of benzo[ $a]$ pyrene exposure in brown bullheads (Ameiurus nebulosus): Journal of Applied Toxicology, v. 12, no. 3, p. 165-177.

Guillette, L.J., Jr., Gross, T.S., Masson, G.R., Matter, J.M., Percival, H.F., and Woodward, A.R., 1994, Developmental abnormalities of the gonad and abnormal sex hormone concentrations in juvenile alligators from contaminated and control lakes in Florida: Environmental Health Perspectives, v. 102 , p. $680-688$.

Hamelink, J.L., Waybrant, R.C., and Ball, R.C., 1971, A proposal: exchange equilibria control the degree chlorinated hydrocarbons are biologically magnified in lentic enviornments: Transactions of the American Fisheries Society, v. 100 , p. 207-214.

Harder, H.W., Carter, T., and Bidleman, T.F., 1983, Acute effects of toxaphene and its sediment-degraded products on estuarine fish: Canadian Journal of Fisheries and Aquatic Sciences, v. 40, no. 12, p. 2119-2125.

Healy, D.F., 1997, Water-quality assessment of the Rio Grande Valley, Colorado, New Mexico, and Texas: summary and analysis of water-quality data for the basic-fixed-site network, 1993-1995: U.S. Geological Survey, Water-Resources Investigations Report nr 97-4212, 82 p.

Heinz, G.H., 1979, Methylmercury: reproductive and behavioral effects on three generations of mallard ducks: Journal of Wildlife Management, v. 43, p. 394-401.

Heinz, G.H., and Hoffman, D.J., 1998, Methylmercury chloride and selenomethionine interactions on health and reproduction in mallards: Environmental Toxicology and Chemistry, v. 17, p. 139-145.

Henderson, D.F., and Kleiner, D.J., 2002, Handbook of Texas online: coal and lignite mining: http://www.tsha.utexas. edu/handbook/online/.

Henny, C.L., Blus, L.J., Hoffman, D.J., and Grove, R.A., 1994, Lead in hawks, falcons and owls downstream from a mining site on the Coeur d'Alene River, Idaho: Environmental Monitoring and Assessment, v. 29, p. 267-288.

Henny, C.L., Blus, L.J., Hoffman, D.J., Sileao, L., Audet, D.J., and Snyder, M.R., 2000, Field evaluation of lead effects on Canada geese and mallards in the Coeur d'Alene Basin, Idaho: Archives of Environmental Contamination and Toxicology, v. 39, p. 97-112.

Herbert, B., Michaud, P., Tissot, P., Louchouarn, P., and Parker, R., 2001, Contamiants from South Texas uranium mines: environmental fate from molecular to watershed scales: http://meridian.tamucc.edu/projects/ 
Hermanutz, R.O., Allen, K.N., Roush, T.H., and Hedtke, S., 1992, Effects of elevated selenium concentrations on bluegills (Lepomis macrochirus) in outdoor experimental streams: Environmental Toxicology and Chemistry, v. 11, p. 217-224.

Hinton, D.E., 1993, Toxicologic histopathology of fishes: a systemic approach and overview, in Couch, J.A., and Fournie, J.W., eds., Pathobiology of marine and estuarine organisms: Boca Raton, FL, CRC Press.

Hinton, D.E., Baumann, P.C., Gardner, G.R., Hawkins, W.E., Hendricks, J.D., Murchelano, R.A., and Okihiro, M.S., 1992, Histopathologic biomarkers, in Huggett, R.J., Kimerle, R.A., Mehrle, P.M., Jr., and Bergman, H.A., eds., Biomarkers: biochemical, physiological, and histological markers of anthropogenic stress: Chelsea, MI, Lewis Publishers, p. 155-210.

Hoffman, D.J., and Heinz, G.H., 1998, Effects of mercury and selenium on glutathione metabolism and oxidative stress in mallard ducks: Environmental Toxicology and Chemistry, v. 17, p. 161-166.

Hoffman, G.K., 1999, New Mexico's coal industry: http://geoinfo.nmt.edu/staff/hoffman/nmgs99.htm.

Holcombe, G.W., Benoit, D.A., Leonard, E.N., and McKim, J.M., 1976, Long-term effects of lead exposure on three generations of brook trout (Salvelinus fontinalis): Journal of the Fisheries Research Board of Canada, v. 33, p. 17311741.

Hooper, G.W., Aulenbach, R.P., and Kelly, V.J., 2001, The National Stream Quanlity Accounting Network: a fluxbased approach to monitoring the water quality of large rivers: Hydrologic Processes, v. 15, no. 7, p. 1089-1106.

Hopkins, C.L., Solly, S.R.B., and Ritchie, A.R., 1969, DDT in trout and its possible effect on reproductive potential: New Zealand Journal of Marine and Freshwater Research, v. 3, p. 220-229.

Hunter, R.G., Carroll, J.H., and Butler, J.S., 1981, The relationship of trophic level to arsenic burden in fish of a southern Great Plains lake: Journal of Freshwater Ecology, v. 1, p. 121-127.

Irwin, R.J., 1989, Toxic chemicals in fish and wildlife at Big Bend National Park, Texas: U.S. Fish and Wildife Service.

Jarvinen, A.W., and Ankley, G.T., 1999, Linkage of effects to tissue residues: development of a comprehensive database for aquatic organisms exposed to inorganic and organic chemicals: Pensacola, FL, SETAC Press, 358 p.

Jearld, A., Jr., 1983, Age determination, in Nielsen, L.A., and Johnson, D.L., eds., Fisheries techniques: Bethesda, MD, American Fisheries Society, p. 301-324.
Jobling, S., Nolan, M., Tyler, C.R., Brighty, G., and Sumpter, J.P., 1998, Widespread sexual disruption in wild fish: Environmental Science \& Technology, v. 32, p. 2498-2506.

Johnson, L.L., Casillas, E., Collier, T.K., McCain, B.B., and Varanasi, U., 1988, Contaminant effects on ovarian development in English sole (Parophyrs vetulus) from Puget Sound, Washington: Canadian Journal of Fisheries and Aquatic Sciences, v. 45, no. 12, p. 2133-2146.

Johnson, M.D., Kenney, N., Stopica, A., Hilakivi-Clarke, L., Sing, B., Chepko, G., Clarke, R., Sholler, P.F., Lirio, A.A., Foss, C., Reiter, R., Trock, B., Paik, S., and Martin, M.B., 2003, Cadmium mimics the in vivo effects of estrogen in the uterus and mammary gland: Nature Medicine, v. 9, p. 1081-1084.

Johnson, W.L., and Finley, M.T., 1980, Handbook of acute toxicity of chemicals to fish and aquatic invertebrates: summaries of toxicity tests conducted at Columbia National Fisheries Research Lab, 1965-78: U.S. Fish and Wildlife Service, Resource Publication 137, 98 p.

June, F.C., 1970, Atresia and year-class abundance of northern pike, Esox lucius, in two Missouri River impoundments: Journal of the Fisheries Research Board of Canada, v. 27, no. 3, p. 587-591.

1977, Reproductive patterns in seventeen species of warmwater fishes in a Missouri River reservior: Environmental Biology of Fishes, v. 2, no. 3, p. 285-296.

Kaiser, K.L.E., 1987, The rise and fall of mirex: Environmental Science \& Technology, v. 12, p. 520-528.

Kania, H.J., and O'Hara, J., 1974, Behavioral alterations in a simple predator-prey system due to sublethal exposure to mercury: Transactions of the American Fisheries Society, v. 103, p. 134-136.

Karr, J.R., 1981, Assessment of biotic integrity using fish communities: Fisheries, v. 6, no. 6, p. 21-27.

Kennedy, S.W., and Jones, S.P., 1994, Simultaneous measurement of cytochrome P4501A catalytic activity and total protein concentration with a fluorescence plate reader: Analytical Biochemistry, v. 222, p. 217-223.

Kidd, D.E., Johnson, G.V., and Garcia, J.D., 1974, An analysis of mercurials in the Elephant Butte ecosystem: University of New Mexico, Albuquerque, Technical Completion Report nr A-040-NMEX, 126.

Kohout, M.D., 2004, Handbook of Texas online: smeltertown, Texas: http://www.tsha.utexas.edu/handbook/online/.

Kuehl, D.W., Butterworth, B., and Marquis, P.J., 1994, A national study of chemical residues in fish. III: Chemosphere, v. 29, no. 3, p. 523-535. 
Law, R.J., 1996, Metals in marine mammals, in Beyer, W.N., Heinz, G.H., and Redmon-Norwood, A.W., eds., Environmental contaminants in wildlife: interpreting tissue concentrations: Boca Raton, FL, Lewis Publishers, p. 357-376.

Lee, K.E., Blazer, V.S., Denslow, N.D., Goldstein, R.M., and Talmage, P.J., 2000, Use of biological characteristics of common carp (Cyprinus carpio) to indicate exposure to hormonally active agents in selected Minnesota streams, 1999: U.S. Gelogical Survey, Water Resources Division, WaterResources Investigations Report nr 00-4202, 47 p.

Lemly, A.D., 1996, Assessing the toxic threat of selenium to fish and aquatic birds: Environmental Monitoring and Assessment, v. 43, p. 19-35.

2002, Selenium assessment in aquatic ecosystems: New York, NY, Springer-Verlag 160 p.

Leonard, P.M., and Orth, D.J., 1986, Application and testing of an index of biotic integrity in small, coolwater streams: Transactions of the American Fisheries Society, v. 115, p. 401-414.

Levings, G.W., Healy, D.F., Richey, S.F., and Carter, L.F., 1998, Water-quality of the Rio Grande Valley, Colorado, New Mexico, and Texas, 1992-95: U.S. Geological Survey, Survey Circular 1162, 39 p.

Li, Y.-F., McMillan, A., and Scholtz, M.T., 1996, Global HCH usage with $1^{\circ} \mathrm{x} 1^{\circ}$ longitude/latitude resolution: Environmental Science \& Technology, v. 30, no. 12, p. 3525-3533.

Lorenzen, A., and Kennedy, S.W., 1993, A fluorescence-based protein assay for use with a microplate reader: Analytical Biochemistry, v. 214, p. 346-348.

Lowe, T.P., May, T.W., Brumbaugh, W.G., and Kane, D.A., 1985, National Contaminant Biomonitoring Program--concentrations of seven elements in freshwater fish, 1978-1981: Archives of Environmental Contamination and Toxicology, v. 14, p. $363-388$.

Luna, L.G., 1992, Histopathological methods and color atlas of special stains and tissue artifacts: Gaithersburg, MD, American Histolabs, Inc., 767 p.

Macek, K.J., Rodgers, C.R., Stalling, D.L., and Korn, S., 1970, The uptake, distribution and elimination of dietary ${ }^{14} \mathrm{C}$ DDT and ${ }^{14} \mathrm{C}$-Dieldrin in rainbow trout: Transactions of the American Fisheries Society, v. 99, p. 689-695.

MacWhorter, W., 2004, Handbook of Texas online: Llano Grande Lake: http://www.tsha.utexas.edu/handbook/online/.

Maeda, S., 1994, Biotransformation of arsenic in the freshwater environment, in Nriagu, J.O., ed., Arsenic in the environment, part I: cycling and characterization: New York, NY, Wiley and Sons, p. 155-187.
Mahler, B.J., and Van Metre, P.C., 2002, Llano Grande Lake bottom sediments--a chronicle of water-quality changes in the Arroyo Colorado, South Texas, 1989-2002: U.S. Geological Survey, Fact Sheet 065-02, 4 p.

May, T.W., and McKinney, G.L., 1981, Cadmium, mercury, arsenic, and selenium concentrations in freshwater fish, 1976-1977--National Pesticide Monitoring Program: Pesticides Monitoring Journal, v. 15, p. 14-38.

Mayer, F.L., Jr., Mehrle, P.M., and Crutcher, P.L., 1978, Interactions of toxaphene and vitamin $\mathrm{C}$ in channel catfish: Transactions of the American Fisheries Society, v. 107, p. 326-333.

Mayer, F.L., Jr., Mehrle, P.M., Jr., and Dwyer, W.P., 1975, Toxaphene effects on reproduction, growth, and mortality of brook trout: U.S. Environmental Protection Agency, EPA600/3-75/013.

McDonald, K., Gross, T.S., Denslow, N.D., Densmore, C.L., Blazer, V.S., and Arnold, B.S., 2002, Reproductive Biomarkers, in: Schmitt, C.J. ed., Biomonitoring of Environmental Status and Trends (BEST) Program: environmental contaminants and thier effects on fish in the Mississippi River basin: U.S. Geological Survey, Biological Resources Division, Biological Science Report nr 2002-0004, 135-170.

McDonald, K.K., Gross, T.S., Denslow, N.D., and Blazer, V.S., 2000, Reproductive indicators, in Schmitt, C.J. and Dethloff, G.M. eds., Biomonitoring of Environmental Status and Trends (BEST) Program: selected methods for monitoring chemical contaminants in aquatic ecosystems: U.S. Geological Survey, Biological Resources Division, Information and Technology Report nr 2000-0005, 30-41.

McGreachy, S.M., and Dixon, D.G., 1990, Effect of temperature on the chronic toxicity of arsenate to rainbow trout (Oncorhynchus mykiss): Canadian Journal of Fisheries and Aquatic Science, v. 47, p. 2228-2234.

1992, Whole-body arsenic concentrations in rainbow trout during acute exposure to arsenate: Ecotoxicology and Environmental Safety, v. 24, p. 301-308.

McKim, J.M., Olson, G.F., Holcombe, G.W., and Hunt, E.P., 1976, Long-term effects on methylmercuric chloride on three generations of brook trout (Salvelinus fontinalis): Toxicity, accumultion, distribution, and elimination: Journal of the Fisheries Research Board of Canada, v. 33, p. 27262739 .

Metz, L.C., 2002, Handbook of Texas online: Rio Grande: http://www.tsha.utexas.edu/handbook/online/.

Minier, C., Caltot, G., Leboulanger, F., and Hill, E.M., 2002, An investigation of the incidence of intersex fish in SeineMaritime and Sussex region: Analysis, v. 28, p. 801-806. 
Mora, M.A., 2001, GIS database for environmental contaminants in the Rio Grande/Rio Bravo basin [compact disc]: U.S. Geological Survey, Columbia Environmental Research Center, Brazos Field Research Station.

Mora, M.A., Lee, M.C., Jenny, J.P., Schultz, T.W., Sericano, J.L., and Clum, N.J., 1997, Potential effects of environmental contaminants on recovery of the aplomado falcon in South Texas: Journal of Wildlife Management, v. 61, p. 1288-1296.

Mora, M.A., Papoulias, D., Nava, I., and Buckler, D.R., 2001, A comparative assessment of contaminants in fish from four resacas of the Texas USA-Tamaulipas, Mexico border region: Environment International , v. 27, p. 15-20.

Mora, M., Skiles, R., McKinney, B., Paredes, M., Buckler, D., and Papoulias, D.K.D., 2002, Environmental contaminants in prey and tissues of the peregrine falcon in the Big Bend Region, Texas, USA: Environmental Pollution, v. 116, p. 169-176.

Mora, M.A., and Wainwright, S.E., 1997, Environmental contaminants in biota of the Rio Grande/Rio Bravo Basin: A review of status and trends, in: Biomonitoring of Environmental Status and Trends (BEST) Program Internal Report: U.S. Geological Survey, Biological Resources Division.

Mora, M.A., and Wainwright, S.E., 1998, DDE, mercury, and selenium in biota, sediments, and water of the Rio GrandeRio Bravo basin, 1965-1995: Reviews of Environmental Contamination and Toxicology, v. 158, p. 1-52.

Moring, J.B., 1999, Use of semipermeable membrane devices (SPMD) to assess occurrence and estimate water concentrations of selected organic compounds in the Rio Grande from Presidio to Brownsville, Texas: U.S. Geological Survey, Fact Sheet 100-99, 6 p.

Muir, D., Braune, B., DeMarch, D., Norstrom, R., Wagemann, R., Lockhart, L., Hargrave, B., Bright, D., Addison, R., Payne, J., and Reimer, K., 1999, Spatial and temporal trends and effects of contaminants in the Canadian Arctic marine ecosystem: a review: Science of the Total Environment, v. 230, p. 83-144.

Nagahama, Y., 1983, The functional morphology of teleost gonads, in Hoar, W.S., Randall, D.J., and Donaldson, E.M., eds., Fish physiology, vol IX: Orlando, FL, Academic Press, Inc., p. 223-264.

Newell, A.J., Johnson, D.W., and Allen, L.K., 1987, Niagara River biota contamination project: fish flesh cirteria for piscivorous wildlife: New York State Deptartment of Environmental Conservation, Division of Fish and Wildlife, Bureau of Environmental Protection, Technical Report nr 87-3, 180 p.
Nosek, J.A., Craven, S.R., Sullivan, J.R., Hurley, S.S., and Peterson, R.E., 1992, Toxicity and reproductive effects of 2,3,7,8-tetrachlorodibenzo- $p$-dioxin in ring-necked pheasant hens: Journal of Toxicology and Environmental Health, v. 35, p. 187-198.

Ong, K., O’Brien, T.F., Rucker, M.D., 1991, Reconnaissance investigation of water quality, bottom sediment, and biota associated with irrigation drainage in the middle Rio Grande valley and Bosque del Apache National Wildlife Refuge, New Mexico, 1988-1989: U.S. Geological Survey, Albuquerque, NM, Water Resources Investigations Report nr 91-4036, $113 \mathrm{p}$.

Outridge, P.M., and Scheuhammer, A.M., 1993, Bioaccumulation and toxicology of chromium: implications for wildlife: Reviews of Environmental Contamination and Toxicology, v. 130, p. 31-77.

Peakall, D.B., 1996, Dieldrin and other cyclodiene pesticides in wildlife, in Beyer, W.N., Heinz, G.H., and Redmon-Norwood, A.W., eds., Environmental contaminants in wildlife: interpreting tissue concentrations: Boca Raton, FL, Lewis Publishers, p. 73-97.

Peterson, S.A., Herlihy, A.T., Hughes, R.M., Motter, K.L., and Robbins, J.M., 2002, Level and extent of mercury contamination in Oregon, USA, lotic fish: Environmental Toxicology and Chemistry, v. 21, no. 10, p. 2157-2164.

Pfeil, J.J., Laveitt, A.J., Wilks, M.E., Azevedo, S., Hemenway, L., Glesener, K., and Barker, J.M., 2002, Mines, mills and quarries in New Mexico, 2001: New Mexico Bureau of Mining and Mineral Resources, Institute of Mining and Technology, $46 \mathrm{p}$.

Pohl, R.J., and Fouts, J.R., 1980, A rapid method for assaying the metabolism of 7-ethoxyresorufin by microsomal subcellular fractions: Analytical Biochemistry, v. 107, p. 150-155.

Poissant, L., and Koprivnjak, J.-F., 1996, Fate and atmospheric concentrations of $\alpha$ - and $\gamma$-Hexachlorcyclohexane in Quebec, Canada: Environmental Science \& Technology, v. 30, no. 3 , p. 845-851.

Propst, D.L., 1999, Threatened and endangered fishes of New Mexico: New Mexico Department of Game and Fish, Technical Report nr 1, 1999, 84 p.

Reynolds, J.B., 1983, Electrofishing, in Nielsen, L.A., and Johnson, D.L., eds., Fisheries Techniques: Bethesda, MD, American Fisheries Society, p. 147-163.

Ribick, M.A., Dubay, G.R., Petty, J.D., Stalling, D.L., and Schmitt, C.J., 1982, Toxaphene residues in fish: identification, quantification, and confirmation at part per billion levels: Environmental Science \& Technology, v. 16, p. 310-318. 
Rodriguez, J.N., Oteme, Z.J., and Hem, S., 1995, Comparative study of vitellogenesis of two African catfish species Chrysichthys nigrodigitatus (Claroteidae) and Heterobranchus longifilis (Clariidae): Aquatic Living Resources, v. 8, p. 291-296.

Roy, R., O’Brien, T.F., and Rusk-Maghini, M., 1992, Organochlorine and trace element contaminant investigation of the Rio Grande, New Mexico: New Mexico Ecological Services Field Office, Contaminants Report, 29 p.

Sanders, R.E., Miltner, R.J., Yoder, C.O., and Rankin, E.T., 1999, The use of external deformities, erosion, lesions, and tumors (DELT anomalies) in fish assemblages for characterizing aquatic resources: a case study of seven Ohio streams, in Simon, T.P., ed., Assessing the sustainability and biological integrity of water resources using fish communities: Boca Raton, FL, CRC Press, p. 225-246.

Schlenk, D., Perkins, E.J., Hamilton, G., Zhang, Y.S., and Layher, W., 1996a, Correlation of hepatic biomarkers with whole animal and population-community metrics: Canadian Journal of Fisheries and Aquatic Sciences, v. 53, no. 10, p. 2299-2309.

Schlenk, D., Perkins, E.J., Layher, W.G., and Zhang, Y.S., 1996b, Correlating metrics of fish health with cellular indicators of stress in an Arkansas bayou: Marine Environmental Research, v. 42, no. 1-4, p. 247-251.

Schmitt, C.J., 1998, Environmental contaminants, in Mac, M.J., Opler, P.A., Puckett Haecker, C.E., and Doran, P.D., eds., Status and trends of the nation's biological resources, volume 1: Reston, Va., U.S. Department of the Interior, U.S. Geological Survey, p. 131-165.

2002a, ed., Biomonitoring of Environmental Status and Trends (BEST) Program: environmental contaminants and their effects on fish in the Mississippi River basin: U.S. Geological Survey, Biological Resources Division, Biological Science Report nr 2002-0004, 217 p.

2002b, Organochlorine chemical residues in fish from the Mississippi River Basin, 1995: Archives of Environmental Contamination and Toxicology, v. 43, p. 81-97.

2004, Concentrations of arsenic, cadmium, copper, lead, selenium, and zinc in fish from the Mississippi River basin, 1995: Environmental Monitoring and Assessment, v. 90, p. 289-321.

Schmitt, C.J., Blazer, V.S., Dethloff, G.M., Tillitt, D.E., Gross, T.S., Bryant, W.L., Jr., DeWeese, L.R., Smith, S.B., Goede, R.W., Bartish, T.M., and Kubiak, T.J., 1999a, Biomonitoring of Environmental Status and Trends (BEST) Program: field procedures for assessing the exposure of fish to environmental contaminants: U.S. Geological Survey, Biological Resources Division, Information and Technology Report 1999-0007, 68 p.
Schmitt, C.J., and Brumbaugh, W.G., 1990, National Contaminant Biomonitoring Program: concentrations of arsenic, cadmium, copper, lead, mercury, selenium, and zinc in freshwater fishes of the United States, 1976-1984: Archives of Environmental Contamination and Toxicology, v. 19, p. 731-747.

Schmitt, C.J., and Bunck, C.M., 1995, Persistent environmental contaminants in fish and wildlife, in LaRoe, E.T., Farris, G.S., Puckett, C.E., Doran, P.D., and Mac, M.J., eds., Our living resources: a report to the nation on the distribution, abundance, and health of U.S. plants, animals, and ecosystems: Washington, D.C., National Biological Service, p. 413-416.

Schmitt, C.J., Caldwell, C.A., Olsen, B., Serdar, D., and Coffey, M., 2002a, Inhibition of erythorcyte $\delta$-aminolevulinc acid dehydratase (ALAD) activity in fish from waters affected by smelters: Environmental Monitoring and Assessment, v. 77, p. 99-119.

Schmitt, C.J., and Dethloff, G.M., eds., 2000, Biomonitoring of Environmental Status and Trends (BEST) program: selected methods for monitoring chemical contaminants and their effects in aquatic ecosystems: U.S. Geological Survey, Information and Technology Report nr 2000-0005, 81 p.

Schmitt, C.J., Dwyer, F.J., and Finger, S.E., 1984, Bioavailability of $\mathrm{Pb}$ and $\mathrm{Zn}$ from mine tailings as indicated by erythrocyte aminolevulinic acid dehydratase (ALA-D) activity in suckers (Pisces: catostomidae): Canadian Journal of Fisheries and Aquatic Sciences, v. 41, p. 1030-1040.

Schmitt, C.J., and Finger, S.E., 1987, The effects of sample preparation on measured concentrations of eight elements in the edible tissues of fish from streams contaminated by lead mining: Archives of Environmental Contamination and Toxicology, v. 16, p. 185-207.

Schmitt, C.J., Tillitt, D.E., Dethloff, G.M., Bartish, T.M., Blazer, V.S., Gross, T.S., and Wright, B.E., 2002b, Project overview, in: Schmitt, C.J. ed., Biomonitoring of Environmental Status and Trends (BEST) Program: environmental contaminants and their effects on fish in the Mississippi River basin: U.S. Geological Survey, Biological Resources Division, Biological Science Report 2002-0004, p. 1-26.

Schmitt, C.J., Tillitt, D.E., and Whyte, J.J., 2002c, Accumulative contaminants, dioxin-equivalent concentrations by H4IIE bioassay, and Ethoxyresorufin- $O$-deethylase (EROD) activity, in: Schmitt, C.J. ed., Biomonitoring of Environmental Status and Trends (BEST) Program: environmental contaminants and their effects on fish in the Mississippi River basin: U.S. Geological Survey, Biological Resources Division, Biological Science Report nr 2002-0004, p. 27-88. 
Schmitt, C.J., Wildhaber, M.L., Hunn, J.B., Nash, T., Tieger, M.N., and Steadman, B.L., 1993, Biomonitoring of leadcontaminated Missouri streams with an assay for erythrocyte $\delta$-aminolevulinic acid dehydratase activity in fish blood: Archives of Environmental Contamination and Toxicology, v. 25, p. 464-475.

Schmitt, C.J., and Winger, P.V., 1980, Factors controlling the fate of pesticides in rural watersheds of the Lower Mississippi River alluvial valley: Transactions of the North American Wildlife and Natural Resources Conference, v. 45 , p. 354-375.

Schmitt, C.J., Zajicek, J.L., May, T.W., and Cowman, D.F., 1999b, Organochlorine residues and elemental contaminants in U.S. freshwater fish, 1976-1986: National Contaminant Biomonitoring Program: Reviews of Environmental Contamination and Toxicology, v. 162, p. 43-104.

Schmitt, C.J., Zajicek, J.L., and Peterman, P.H., 1990, National Contaminant Biomonitoring Program: residues of organochlorine chemicals in freshwater fishes of the United States, 1976-1984: Archives of Environmental Contamination and Toxicology, v. 19, p. 748-782.

Schmitt, C.J., Zajicek, J.L., and Ribick, M.A., 1985, National Pesticide Monitoring Program: residues of organochlorine chemicals in freshwater fish, 1980-81: Archives of Environmental Contamination and Toxicology, v. 14, p. 225-260.

Scholz, N.L., Truelove, N.K., French, B.L., Berejikian, B.A., Quinn, T.P., Casillas, E., and Collier, T.K., 2000, Diazinon disrupts antipredator and homing behaviors in Chinook salmon (Oncorhynchus tshawytscha): Canadian Journal of Fisheries and Aquatic Sciences, v. 57, p. 1911-1918.

Schultz, R., and Hermanutz, R., 1990, Transfer of toxic concentrations of selenium from parent to progeny in the fathead minnow (Pimephales promelas): Bulletin of Environmental Contamination and Toxicology, v. 45, p. 568-573.

Sepúlveda, M.S., Quinn, B.P., Denslow, N.D., Holm, S.E., and Gross, T.S., 2003, Effect of pulp and paper mill effluents on reproductive success of largemouth bass: Environmental Toxicology and Chemistry, v. 22, no. 1, p. 205-213.

Sepúlveda, M.S., Ruessler, D.S., Denslow, N.D., Holm, S.E., Schoeb, T.R., and Gross, T.S., 2001, Assessment of reproduction in largemouth bass (Micropterus salmoides) exposed to bleached/unbleached kraft mill effluents: Archives of Environmental Contamination and Toxicology, v. 41 , p. $475-482$.

Servos, M.R., 1999, Review of the aquatic toxicity, estrogenic responses and bioaccumulation of alkylphenols and alkylphenol polyethoxylates: Water Quality Research Journal of Canada, v. 34, p. 123-177.
Sharpe, R.D., 1980, Development of the mercury mining industry: Trans-Pecos Texas: Mining and Minerals Resources Research Institute, Mineral Resource Circular nr 64, $32 \mathrm{p}$.

Shayne Washburn, B., Vines, C.A., Baden, D.G., Hinton, D.E., and Walsh, P.J., 1996, Differential effects of brevetoxin and beta-naphthoflavone on xenobiotic metabolizing enzymes in striped bass (Morone saxatilis): Aquatic Toxicology, v. 35, p. $1-10$.

Shubat, P.J., and Curtis, L.R., 1986, Ration and toxicant preesposure influence dieldrin accumulation by rainbow trout (Salmo gairdneri): Environmental Toxicology and Chemistry, v. 5, p. 69-77.

Skerfving, S., 1978, Interaction between selenium and methylmercury: Environmental Health Perspectives, v. 25, p. 57-65.

Smith, S.B., Gross, T.S., and Denslow, N.D., 2002, Endocrine biomarkers in largemouth bass (Micropterus salmoides) related to polychlorinated bihenyls in Woods Pond, Husatonic River, Massachusetts: Florida Caribbean Science Center, U.S. Geoloigcal Survey, Report nr 001-2002, 18 p.

Snarski, V.M., and Olson, G.F., 1982, Chronic toxicity and bioaccumulation of mercuric chloride in the fathead minnow (Pimephales promelas): Aquatic Toxicology, v. 2, p. 143-156.

Solé, M., Raldua, D., Piferrer, F., Barceló, D., and Porte, C., 2003, Feminiztion of wild carp, Cyprinus carpio, in a polluted evnironment: plasma steroid hormones, gonadal morphology and xenobiotic metabolizing system: Comparative Biochemistry and Physiology Part C, v. 136, p. 145-156.

Solé, M., Barceló, D., and Prote, C., 2002, Seasonal variation of plasmatic and hepatic vitellogenin and EROD activity in carp, Cyprinus carpio, in relation to sewage treatment plants: Aquatic Toxicology, v. 60, p. 233-248.

Spehar, R.L., 1976, Cadmium and zinc toxicity to flagfish (Jordanella floridae): Journal of the Fisheries Research Board of Canada, v. 33, p. 1939-1945.

Stansley, W., and Roscoe, D.E., 1999, Environmental toxicology-chlordane poisoning of birds in New Jersey, USA: Environmental Toxicology and Chemistry, v. 18, no. 9, p. 2095-2099.

Stouthart, X.J.H.X., Haans, J.L.M., Lock, R.A.C., and Wenderlaar Bonga, S.E., 1996, Effects of water pH on copper toxicity to early life stages of the common carp (Cyprinus carpio): Environmental Toxicology and Chemistry, v. 15, p. 376-383.

Texas Center for Policy Studies (TCPS), 2002, The dispute over shared waters of the Rio Grande/Rio Bravo: a primer: Texas Center for Policy Studies, $17 \mathrm{p}$. 
Texas Natural Resource Conservation Commission (TNRCC) 1994a, Regional assessment of water quality in the Rio Grande Basin, including the Pecos River, the Devils River, the Arroyo Colorado and the Lower Laguna Madre: Watershed Management Division, Texas Natural Resource Conservation Commission, AS-34, 375 p. + appendices.

1994b, Binational study regarding the presence of toxic substances in the Rio Grande/Rio Bravo and its tributaries along the boundary portion between the United States and Mexico, Final Report: 245 p. + appendices.

1996, TNRCC municipal solid waste landfills: http:// www.tnrcc.state.tx.us/gis/sites.html.

1997, Second phase of the binational study regarding the presence of toxic substances in the Rio Grande/Rio Bravo and its tributaries along the boundary portion between the Unites States and Mexico, final report. Volumes I and II.

2002, State of the Rio Grande and the envrionment of the border region strategic plan, fiscal years 2003-2007, Volume 3: SFR-035C/02, $168 \mathrm{p}$.

Thompson, D.R., 1996, Mercury in birds and terrestrial mammals, in Beyer, W.N., Heinz, G.H., and Redmon-Norwood, A.W., eds., Environmental contaminants in wildlife: interpreting tissue concentrations: Boca Raton, FL, Lewis Publishers, p. 341-356.

Tillitt, D.E., Gale, R.W., Meadows, J.C., Zajicek, J.L., Peterman, P.H., Heaton, S.N., Jones, P.D., Bursian, S.J., Kubiak, T.J., Giesy, J.P., and Aulerich, R.J., 1996, Dietary exposure of mink to carp from Saginaw Bay 3. Characterization of dietary exposure to planar halogenated hydrocarbons, dioxin equivalents, and biomagnification: Environmental Science \& Technology, v. 30, no. 1, p. 283-291.

Tillitt, D.E., Giesy, J.P., and Ankley, G.T., 1991, Characterization of the H4IIE rat hepatoma cell bioassay as a tool for assessing toxic potency of planar halogenated hydrocarbons in environmental samples: Environmental Science \& Technology, v. 25, no. 1, p. 87-92.

Toppari, J., Larsen, J.C., Christiansen, P., Giwereman, A., Grandjean, P., Guillette, L.J., Jr., Jegou, B., Jensen, T.K., Jouannet, P., Keiding, N., Leffers, H., McLachlan, J.A., Meyer, O., Muller, J., Rajpert-De Meyts, E., Scheike, T., Sharpe, R., Sumpter, J., and Skakkebaek, N.E., 1995, Male reproductive health and environmental chemicals with estrogenic effects: Danish Environmental Protection Agency, Ministry of Environment and Energy, Miljøprojekt nr 290, $166 \mathrm{p}$.

Treasurer, J.W., and Holliday, F.G.T., 1981, Some aspects of the reproductive biology of perch Perca flaviatilis L.: a histological description of the reproductive cycle: Journal of Fish Biology, v. 18, no. 359-376.
Tyler, C.R., Jobling, S., and Sumpter, J.P., 1998, Endocrine disruption in wildlife: A critical review of the evidence: Critical Reviews in Toxicology, v. 28, p. 319-361.

Tysklind, M., Tillitt, D., Eriksson, L., Lundgren, K., and Rappe, C., 1994, A toxic equivalency factor scale for polychlorinated dibenzofurans: Fundamental and Applied Toxicology, v. 22, no. 2, p. 277-285.

U.S. Dpeartment of the Interior (USDI), 1995, Lower Rio Grand basin study, Texas: summary of water rsources, ecological resources, and socioeconomic conditions: Austin, TX, Bureau of Reclamation.

University of Texas-Pan American (UTPA), 1995, Report of literature review on discharges from the Rio Grande and Arroyo Colorado and thier impacts: Coastal Studies Laboratory, $87 \mathrm{p}$.

van den Heuvel, M.R., Servos, M.R., Munkittrick, K.R., Bols, N.C., and Dixon, D.G., 1996, Evidence for a reduction of 2,3,7,8-TCDD toxic equivalent concentrations in white sucker (Catostomus commersoni) exposed to bleached kraft pulp mill effluent, following process and treatment improvements: Journal of Great Lakes Research, v. 22, no. 2, p. 264-279.

Van Metre, P.C., Mahler, B.J., and Callender, E., 1997, Waterquality trends in the Rio Grande-Rio Bravo basin using sediment cores from reservoirs: U.S. Geological Survey, Fact Sheet 221-96, 8 p.

Vertrees, C., 2002, Handbook of Texas online: Permian basin: http://www.tsha.utexas.edu/handbook/online/.

Vogelbein, W.K., 1993, Ultrastructural and histological characterization of hepatic neoplasms in mummichog Fundulus heteroclitus inhabiting a creosote-contaminated environment: Marine Environmental Research, v. 35, p. 197-198.

Wagemann, R., Snow, N.B., Rosenberg, D.M., and Lutz, A., 1978, Arsenic in sediments, water and aquatic biota from lakes in the vicinity of Yellowknife, Northwest Territories, Canada: Archives of Environmental Contamination and Toxicology, v. 7, p. 169-191.

Wainwright, S.E., Mora, M.A., Sericano, J.L., and Thomas, P., 2001, Chlorinated hydrocarbons and biomarkers of exposure in wading birds and fish of the lower Rio Grande valley, Texas: Archives of Environmental Contamination and Toxicology, v. 40, p. 101-111.

Wells, F., and Reutter, D., 1996, The Rio Grande basin workplan, In: Hooper, R. editor, NASQAN II, redesign plan for the National Stream Quantity Accounting Network: U.S. Geological Survey, 61-74. 
White, D.H., Mitchell, C.A., Kennedy, H.D., Krynitsky, A.J., and Ribick, M.A., 1983, Elevated DDE and toxaphene residues in fishes and birds reflect local contamination in the Lower Rio Grande Valley, Texas: Southwestern Naturalist, v. 28 , p. $325-333$.

Whyte, J.J., Jung, R.E., Schmitt, C.J., and Tillitt, D.E., 2000, Ethoxyresorufin- $O$-deethylase (EROD) activity in fish as a biomarker of chemical exposure: Critical Reviews in Toxicology, v. 30, no. 4, p. 347-570.

Whyte, J.J., Schmitt, C.J., and Tillitt, D.E., 2004, The H4IIE cell bioassay as an indicator of dioxin-like chemicals in wildlife and the environment: Critical Reviews in Toxicology, v. 34, no. 1, p. 1-83.

Wiener, J.G., Krabbenhoft, D.P., Heinz, G.H., and Scheuhammer, A.M., 2002, Ecotoxicology of mercury, in Hoffman, D.J., Rattner, B.A., Burton, G.A., Jr., and Cairns, J., Jr., eds., Handbook of ecotoxicology (2nd ed.): Boca Raton, FL, Lewis Publishers, p. 409-463.

Wiener, J.G., and Spry, D.J., 1996, Toxicological significance of mercury in freshwater fish, in Beyer, W.N., Heinz, G.H., and Redmon-Norwood, A.W., eds., Environmental contaminants in wildlife: interpreting tissue concentrations: Boca Raton, FL, Lewis Publishers, p. 297-339.

Wilcox, R., 1997, Concentrations of selected trace elements and other constituents in the Rio Grande and in fish tissue in the vicinity of Albuquerque, New Mexico, 1994-1996: U.S. Geological Survey, Open-File Report 97-667, 173 p.

Willett, K.L., Ulrich, E.M., and Hites, R.A., 1998, Differential toxicity and environmental fates of hexachlorocylohexane isomers: Environmental Science \& Technology, v. 32, p. 2197-2207.

Williams, T.G., Lockhart, W.L., Metner, D.A., and Harbicht, S., 1997, Baseline studies in the Slave River, NWT, 19901994 Part III. MFO enzyme activity in fish: The Science of the Total Environment, v. 197, p. 87-109.

Wolfe, M.F., Schwarzbach, S., and Sulaiman, R.A., 1998, Effects of mercury on wildlife: a comprehensive review: Environmental Toxicology and Chemistry, v. 17, p. 146160.

Wolke, R.E., 1992, Piscine macrophage aggregates: a review: Annual Review of Fish Diseases, v. 2, p. 91-108.

Wong, C.S., Capel, P.D., and Nowell, L.H., 2000, Organochlorine pesticides and PCBs in stream sediment and aquatic biota--initial results from the National Water-Quality Assessment Program, 1992-1995: U.S. Geological Survey, Water Resources Division, Water-Resources Investigations Report nr 00-4053, 88 p.
Wren, C.D., and Farrell, C.W., 1995, Mercury in the natural gas industry in Canada: Water Air and Soil Pollution, v. 80, p. 1-4.

Yeardley, R.B., Jr., Lazorchak, J.M., and Paulsen, S.G., 1998, Elemental fish tissue contamination in northeastern U.S. lakes: evaluation of an approach to regional assessment: Environmental Toxicology and Chemistry, v. 17, p. 18751884. 


\section{Appendix 1.}




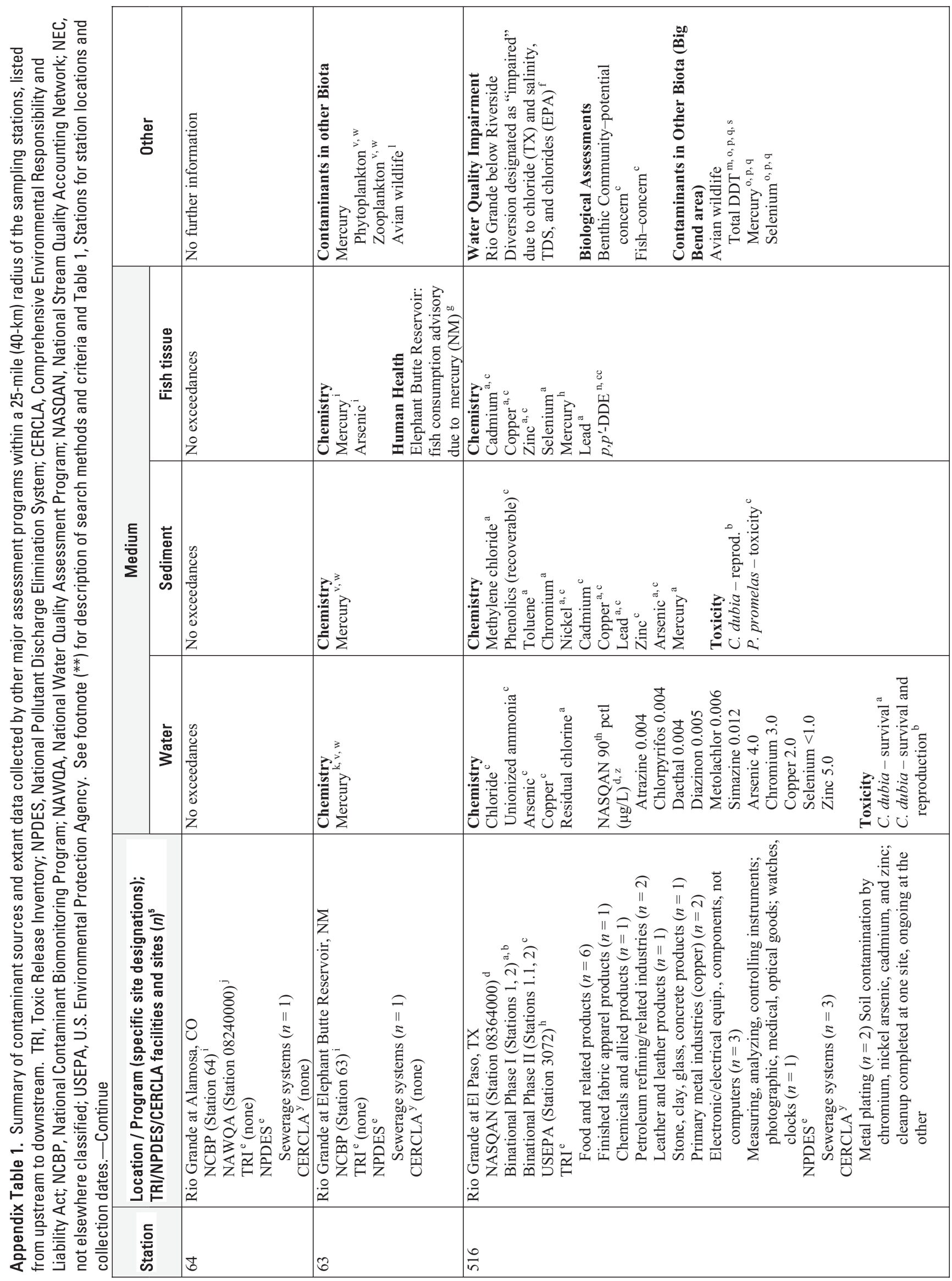




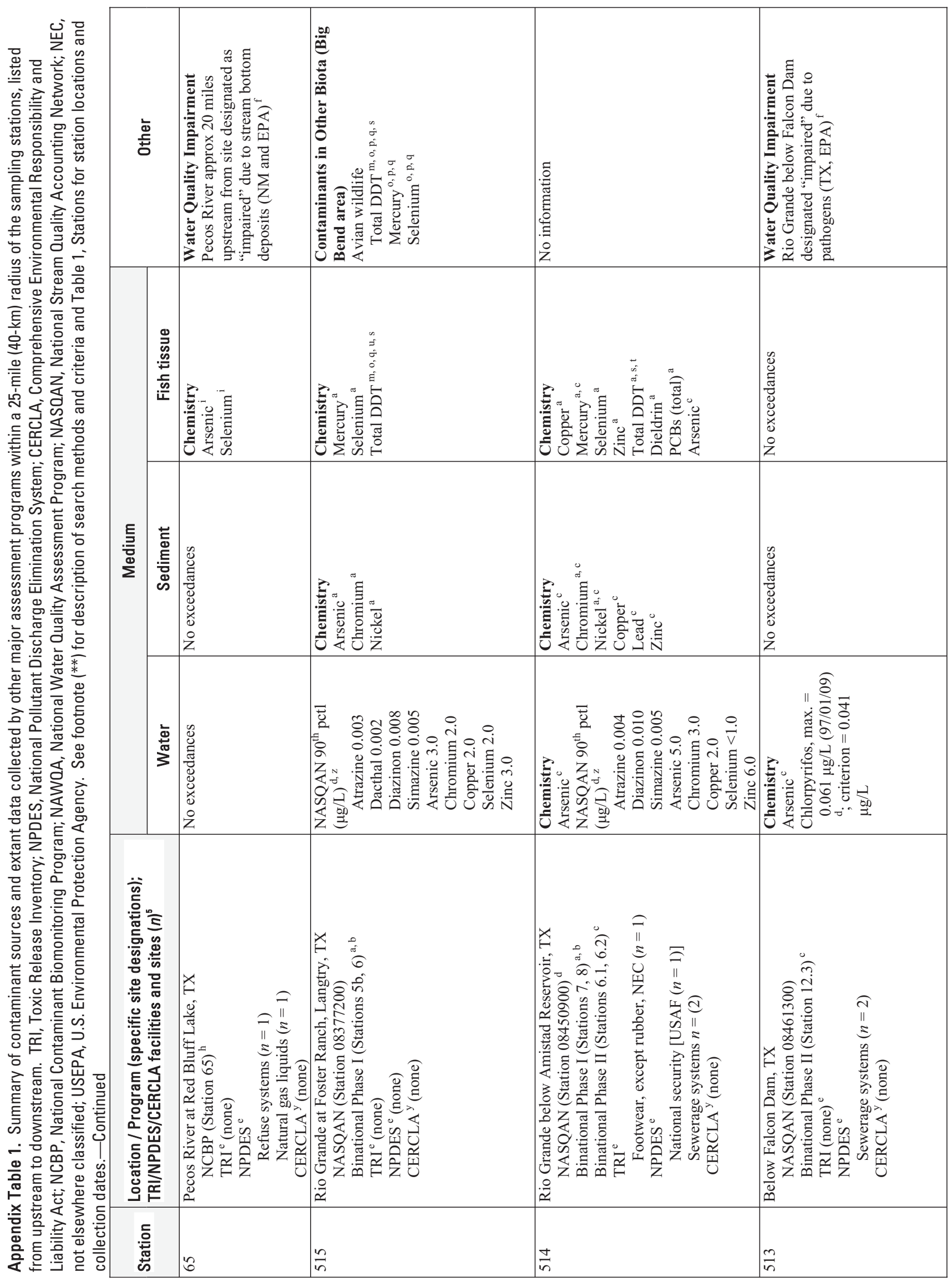




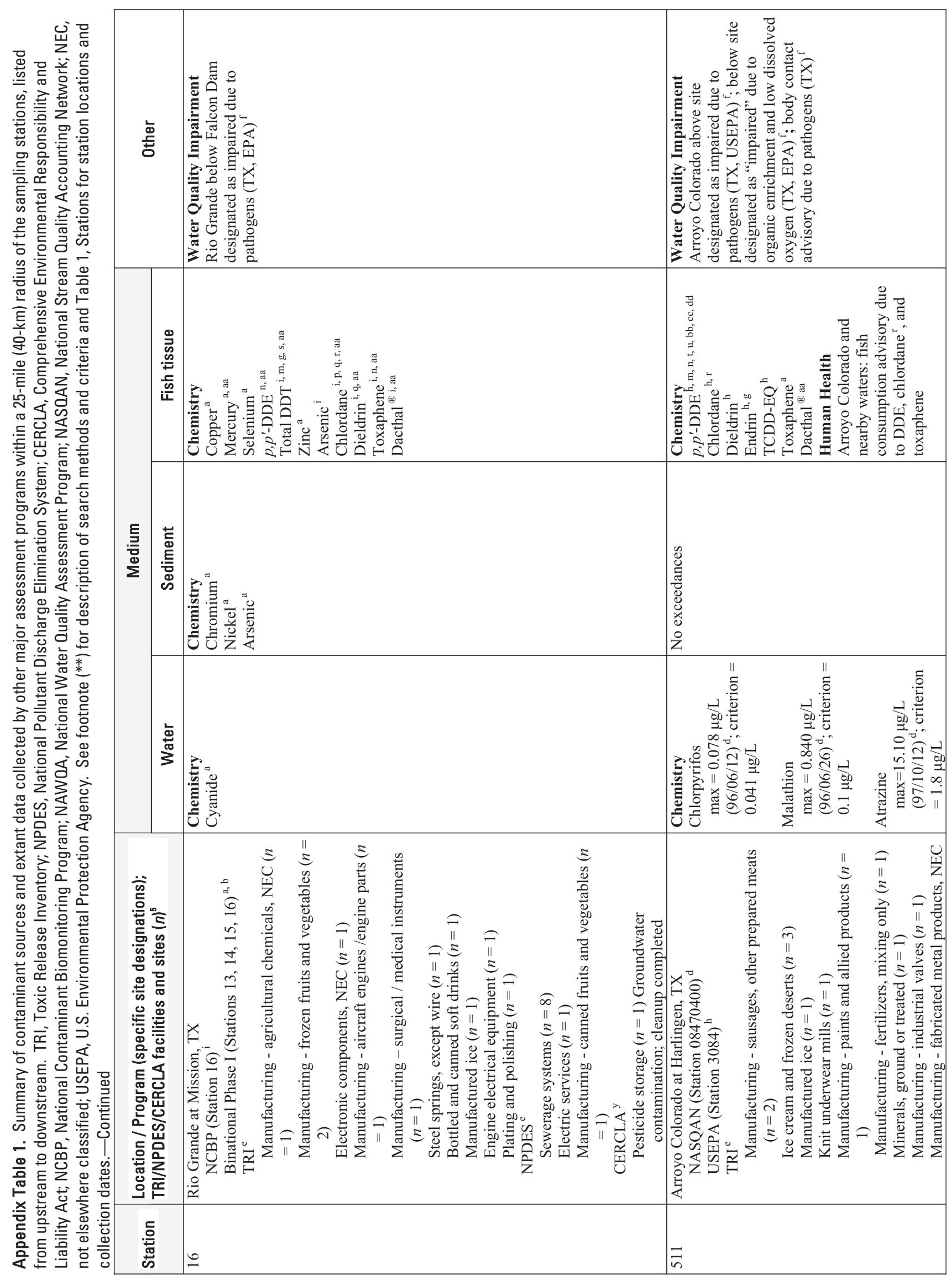




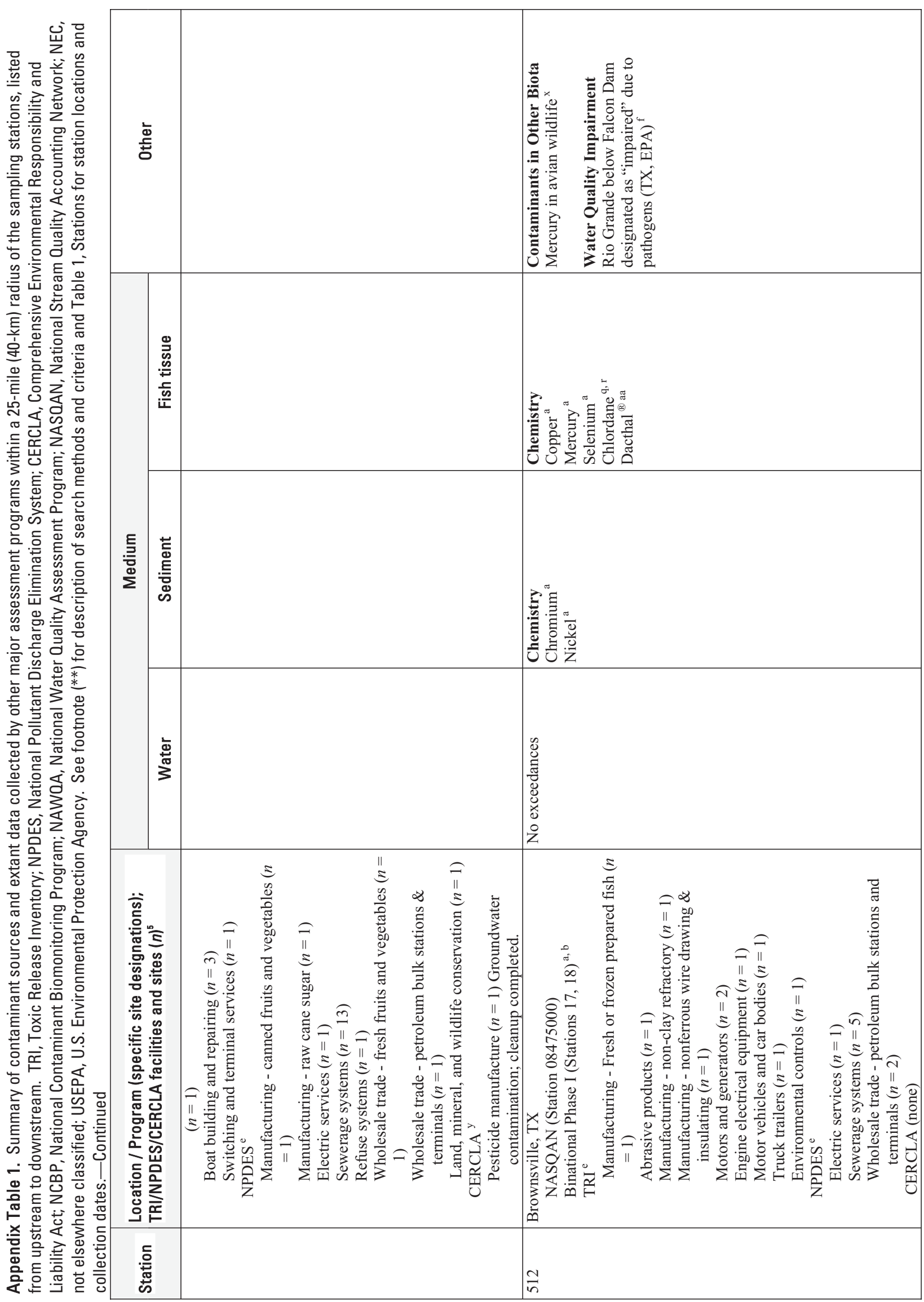



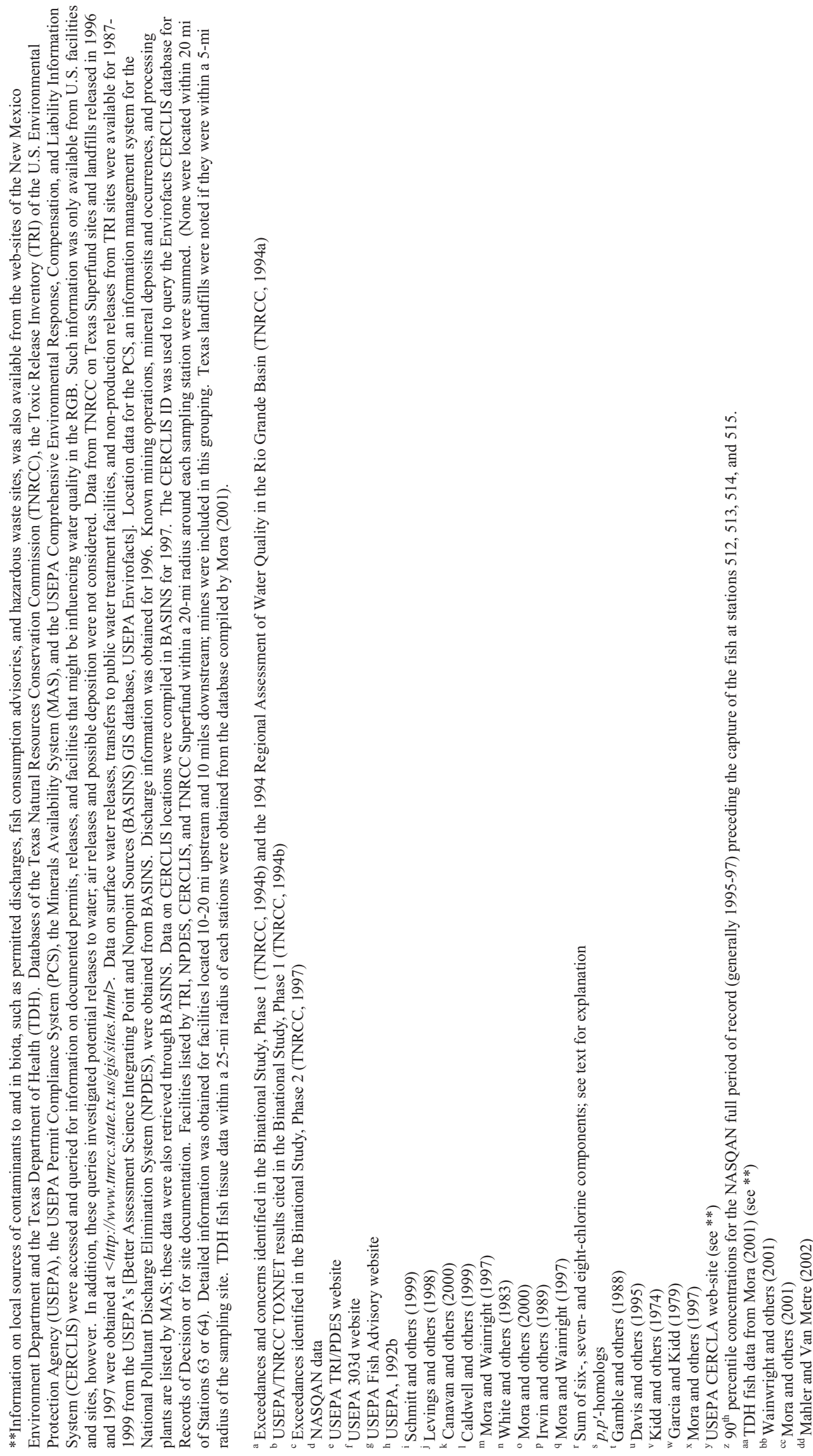
Appendix Table 2. Numbers of fish collected from stations in the Rio Grande Basin, by station, species, and gender ( $M$, male; $F$, female; J, juvenile; NG, no gonad sample obtained). See Table 1 for station locations and collection dates.

\begin{tabular}{|c|c|c|c|c|c|c|c|c|c|}
\hline Station & $\begin{array}{l}\text { Species and } \\
\text { gender }\end{array}$ & $\begin{array}{c}\text { Gender } \\
\text { count }\end{array}$ & $\begin{array}{c}\text { Species } \\
\text { count }\end{array}$ & $\begin{array}{c}\text { Station } \\
\text { count }\end{array}$ & Station & Species and gender & $\begin{array}{l}\text { Gender } \\
\text { count }\end{array}$ & $\begin{array}{c}\text { Species } \\
\text { count }\end{array}$ & $\begin{array}{c}\text { Station } \\
\text { count }\end{array}$ \\
\hline 16 & -- & -- & -- & 41 & 512 & -- & -- & -- & 30 \\
\hline -- & Carp & -- & 20 & -- & -- & Carp & -- & 14 & -- \\
\hline-- & $\mathrm{F}$ & 10 & -- & -- & -- & $\mathrm{F}$ & 6 & -- & -- \\
\hline-- & M & 10 & -- & -- & -- & M & 8 & -- & -- \\
\hline-- & Largemouth bass & -- & 21 & -- & -- & Largemouth bass & -- & 16 & -- \\
\hline-- & $\mathrm{F}$ & 11 & -- & -- & -- & $\mathrm{F}$ & 7 & -- & -- \\
\hline-- & M & 10 & -- & -- & -- & M & 8 & -- & -- \\
\hline-- & -- & -- & -- & -- & -- & NG & 1 & -- & -- \\
\hline 63 & -- & -- & -- & 34 & -- & -- & -- & -- & -- \\
\hline-- & Carp & -- & 25 & -- & 513 & -- & -- & -- & 42 \\
\hline-- & $\mathrm{F}$ & 15 & -- & -- & -- & Carp & -- & 20 & -- \\
\hline-- & M & 10 & -- & -- & -- & $\mathrm{F}$ & 11 & -- & -- \\
\hline-- & Largemouth bass & -- & 6 & -- & -- & M & 9 & -- & -- \\
\hline-- & $\mathrm{F}$ & 4 & -- & -- & -- & Largemouth bass & -- & 22 & -- \\
\hline -- & NG & 2 & -- & -- & -- & $\mathrm{F}$ & 13 & -- & -- \\
\hline-- & Smallmouth bass & -- & 2 & -- & -- & M & 9 & -- & -- \\
\hline -- & $\mathrm{F}$ & 2 & -- & -- & -- & -- & -- & -- & -- \\
\hline -- & Striped bass & -- & 1 & -- & 514 & -- & -- & -- & 28 \\
\hline-- & $\mathrm{F}$ & 1 & -- & -- & -- & Carp & -- & 20 & -- \\
\hline-- & -- & -- & -- & -- & -- & $\mathrm{F}$ & 10 & -- & -- \\
\hline 64 & -- & -- & -- & 56 & -- & M & 10 & -- & -- \\
\hline-- & Carp & -- & 40 & -- & -- & Largemouth bass & -- & 7 & -- \\
\hline-- & $\mathrm{F}$ & 23 & -- & -- & -- & $\mathrm{F}$ & 5 & -- & -- \\
\hline-- & $\mathrm{M}$ & 16 & -- & -- & -- & M & 2 & -- & -- \\
\hline-- & NG & 1 & -- & -- & -- & Smallmouth bass & -- & 1 & -- \\
\hline-- & Northern pike & -- & 16 & -- & -- & M & 1 & -- & -- \\
\hline-- & $\mathrm{F}$ & 6 & -- & -- & -- & -- & -- & -- & -- \\
\hline -- & M & 10 & -- & -- & 515 & -- & -- & -- & 16 \\
\hline-- & -- & -- & -- & -- & -- & Blue catfish & -- & 6 & -- \\
\hline 65 & -- & -- & -- & 41 & -- & $\mathrm{F}$ & 3 & -- & -- \\
\hline -- & Carp & -- & 20 & -- & -- & NG & 3 & -- & -- \\
\hline-- & $\mathrm{F}$ & 10 & -- & -- & -- & Carp & -- & 10 & -- \\
\hline-- & $\mathrm{M}$ & 10 & -- & -- & -- & $\mathrm{F}$ & 6 & -- & -- \\
\hline-- & White bass & -- & 21 & -- & -- & M & 4 & -- & -- \\
\hline-- & $\mathrm{F}$ & 18 & -- & -- & -- & -- & -- & -- & -- \\
\hline-- & M & 3 & -- & -- & 516 & -- & -- & -- & 40 \\
\hline-- & -- & -- & -- & -- & -- & Carp & -- & 18 & -- \\
\hline 511 & -- & -- & -- & 40 & -- & $\mathrm{F}$ & 10 & -- & -- \\
\hline-- & Carp & -- & 20 & -- & -- & M & 8 & -- & -- \\
\hline-- & $\mathrm{F}$ & 13 & -- & -- & -- & Channel catfish & -- & 22 & -- \\
\hline-- & $\mathrm{M}$ & 7 & -- & -- & -- & F & 11 & -- & -- \\
\hline-- & Channel catfish & -- & 20 & -- & -- & M & 2 & -- & -- \\
\hline-- & $\mathrm{F}$ & 8 & -- & -- & -- & $\mathrm{J}$ & 5 & -- & -- \\
\hline-- & $\mathrm{M}$ & 3 & -- & -- & -- & NG & 4 & -- & -- \\
\hline-- & $\mathrm{J}$ & 9 & -- & -- & -- & -- & -- & -- & -- \\
\hline
\end{tabular}


Appendix Table 3. Total lengths, weights, and ages of fishes other than common carp and bass (Micropterus sp.) collected in the Rio Grande Basin, by station and gender (M, male; F, female; J, juvenile; NG, no gonad sample obtained). See Table 1 for station locations and collection dates.

\begin{tabular}{|c|c|c|c|c|c|c|c|c|c|}
\hline \multirow{2}{*}{ Station, taxon, and gender } & \multicolumn{3}{|c|}{ Length (mm) } & \multicolumn{3}{|c|}{ Weight $(\mathrm{g})$} & \multicolumn{3}{|c|}{ Age (y) } \\
\hline & No. fish & Mean & Range & No. fish & Mean & Range & No. fish & Mean & Range \\
\hline \multicolumn{10}{|l|}{ All stations } \\
\hline Catfish $^{\mathrm{a}}$, all & 48 & 381 & $246-650$ & 48 & 567 & $97-2400$ & 48 & 2.4 & $0-7$ \\
\hline Catfish $^{\mathrm{a}}, \mathrm{F}$ & 22 & 367 & $246-650$ & 22 & 505 & $97-2400$ & 22 & 2.5 & $0-7$ \\
\hline Catfish $^{\mathrm{a}}, \mathrm{M}$ & 5 & 439 & $352-464$ & 5 & 816 & $400-1033$ & 5 & 2.6 & $2-3$ \\
\hline Catfish $^{\mathrm{a}}, \mathrm{NG} / \mathrm{J}$ & 21 & 382 & $264-539$ & 21 & 573 & $126-1512$ & 21 & 2.3 & $1-5$ \\
\hline Morone spp., all & 22 & 262 & $202-719$ & 22 & 262 & $85-2300$ & 22 & 0.2 & $0-4$ \\
\hline Morone spp., F & 19 & 265 & $202-719$ & 19 & 276 & $85-2300$ & 19 & 0.2 & $0-4$ \\
\hline Morone spp., M & 3 & 243 & $221-256$ & 3 & 173 & $120-210$ & 3 & 0.0 & $0-0$ \\
\hline Northern pike, all & 16 & 497 & $216-738$ & 16 & 1115 & $61-3000$ & 15 & 1.8 & $0-3$ \\
\hline Northern pike, F & 6 & 575 & $292-738$ & 6 & 1460 & $160-3000$ & 5 & 2.2 & $0-3$ \\
\hline Northern pike, $\mathrm{M}$ & 10 & 450 & $216-652$ & 10 & 908 & $61-1800$ & 10 & 1.6 & $0-3$ \\
\hline \multicolumn{10}{|l|}{ Station 63} \\
\hline Striped bass, F & 1 & 719 & $719-719$ & 1 & 2300 & $2300-2300$ & 1 & 4.0 & $4-4$ \\
\hline \multicolumn{10}{|l|}{ Station 64} \\
\hline Northern pike, F & 6 & 575 & $292-738$ & 6 & 1460 & $160-3000$ & 5 & 2.2 & $0-3$ \\
\hline Northern pike, $\mathrm{M}$ & 10 & 450 & $216-652$ & 10 & 908 & $61-1800$ & 10 & 1.6 & $0-3$ \\
\hline \multicolumn{10}{|l|}{ Station 65} \\
\hline White bass, F & 18 & 239 & $202-268$ & 18 & 164 & $85-335$ & 18 & 0.0 & $0-0$ \\
\hline White bass, M & 3 & 243 & $221-256$ & 3 & 173 & $120-210$ & 3 & 0.0 & $0-0$ \\
\hline \multicolumn{10}{|l|}{ Station 511} \\
\hline Channel catfish, F & 8 & 353 & $305-433$ & 8 & 406 & $213-733$ & 8 & 2.0 & $1-5$ \\
\hline Channel catfish, $\mathrm{M}$ & 3 & 464 & $463-464$ & 3 & 959 & $891-1033$ & 3 & 2.7 & $2-3$ \\
\hline Channel catfish, J & 9 & 414 & $309-539$ & 9 & 720 & $196-1512$ & 9 & 1.9 & $1-4$ \\
\hline \multicolumn{10}{|l|}{ Station 515} \\
\hline Blue catfish, $\mathrm{F}$ & 3 & 383 & $246-650$ & 3 & 868 & $97-2400$ & 3 & 1.3 & $0-3$ \\
\hline Blue catfish, NG & 3 & 295 & $264-327$ & 3 & 169 & $126-231$ & 3 & 1.0 & $1-1$ \\
\hline \multicolumn{10}{|l|}{ Station 516} \\
\hline Channel catfish, F & 11 & 372 & $271-445$ & 11 & 478 & $137-800$ & 11 & 3.1 & $1-7$ \\
\hline Channel catfish, $\mathrm{M}$ & 2 & 402 & $352-451$ & 2 & 600 & $400-800$ & 2 & 2.5 & $2-3$ \\
\hline Channel catfish, NG/J & 9 & 380 & $266-523$ & 9 & 561 & $200-1450$ & 9 & 3.1 & $2-5$ \\
\hline
\end{tabular}

${ }^{\mathrm{a}}$ Channel catfish (Ictalurus punctatus) and blue catfish (I. furctatus) 


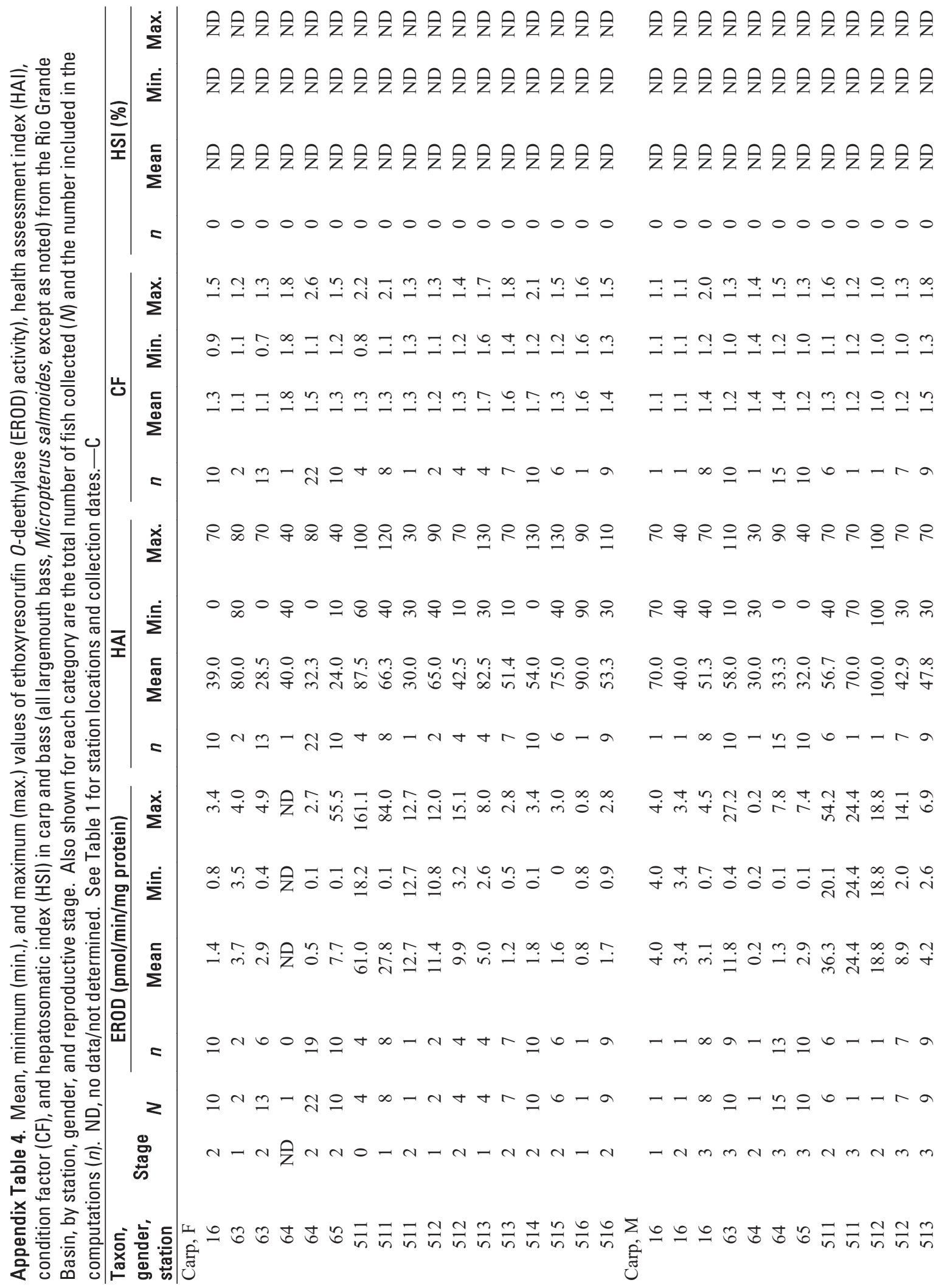




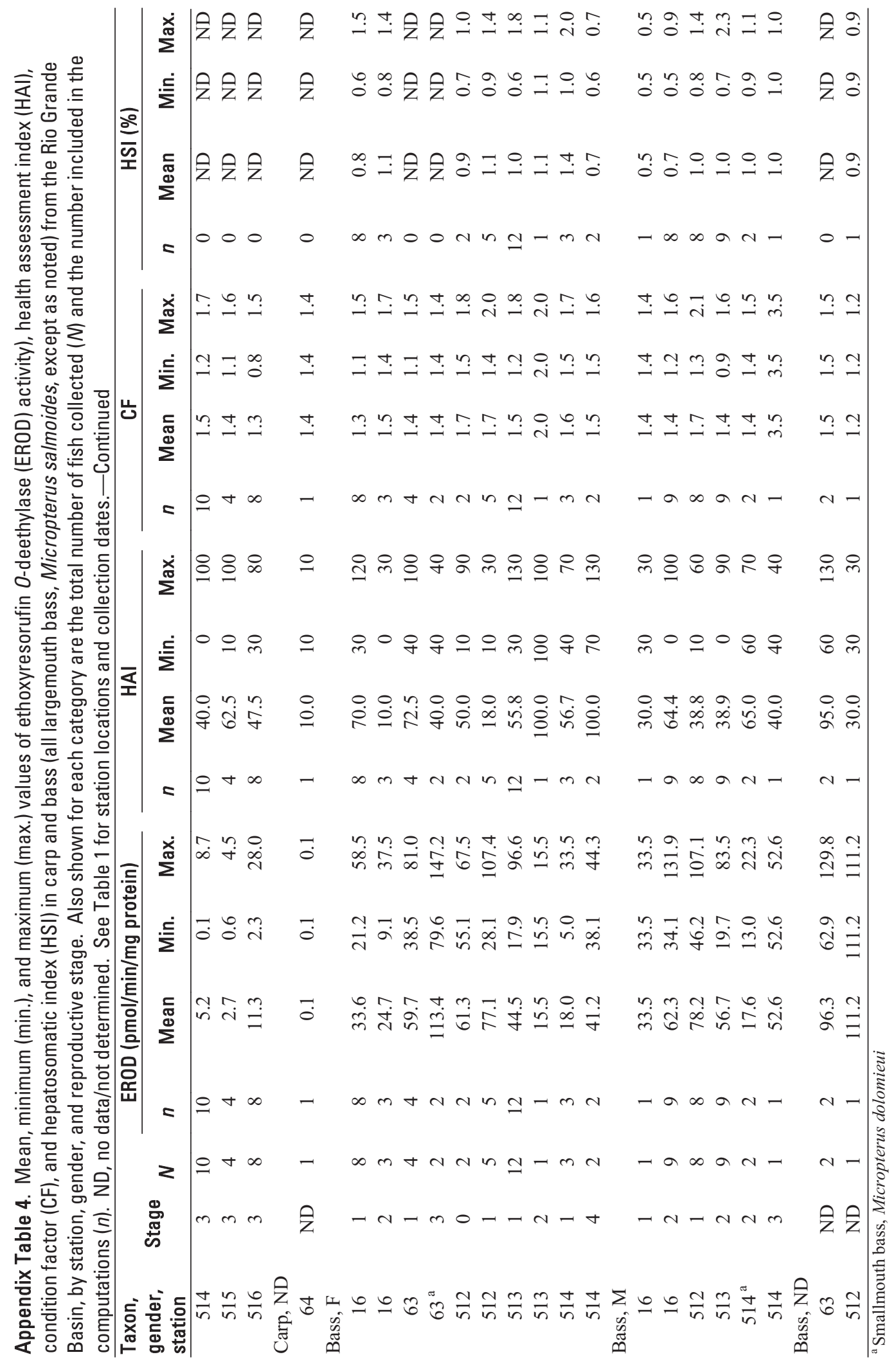




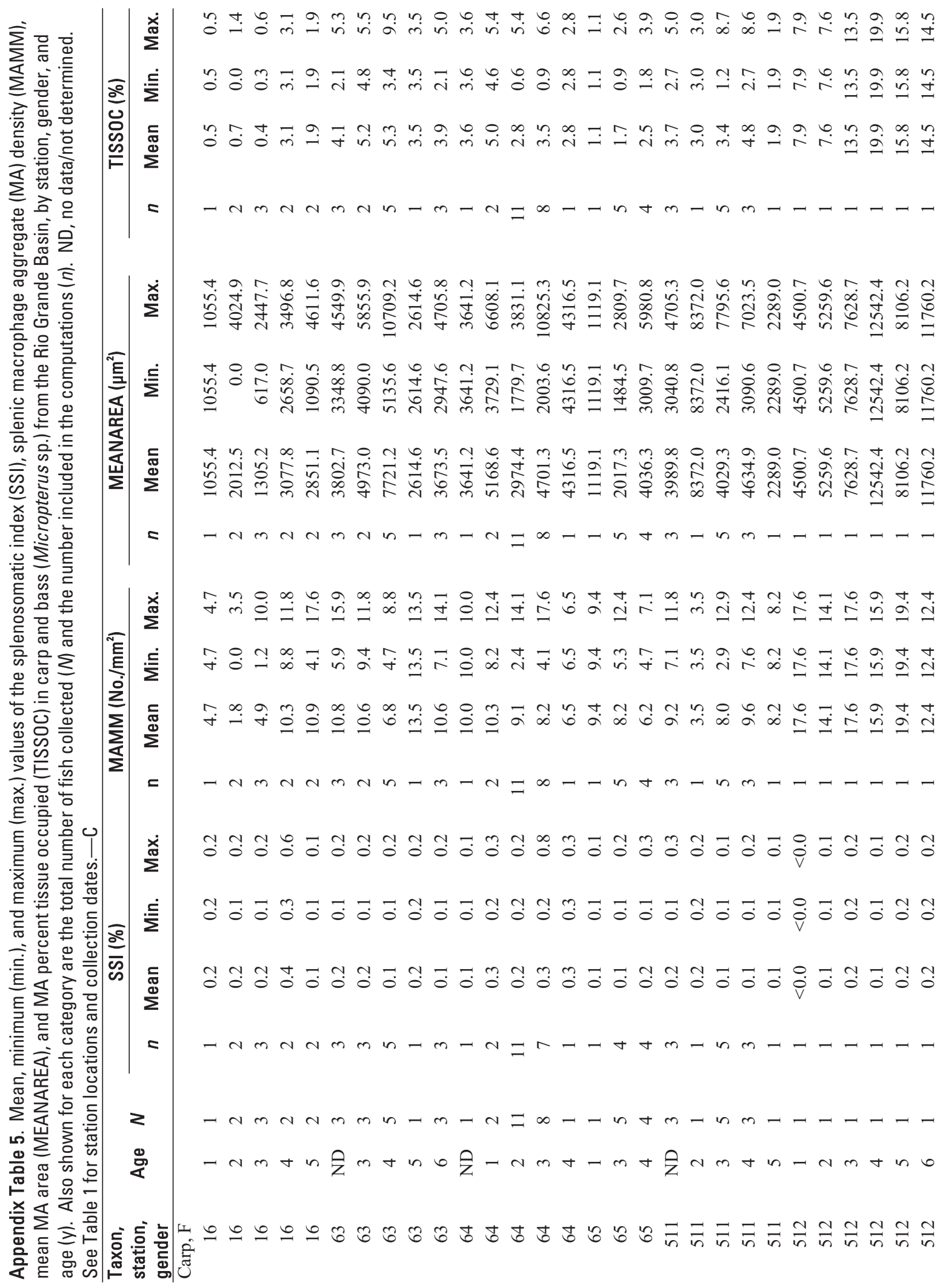




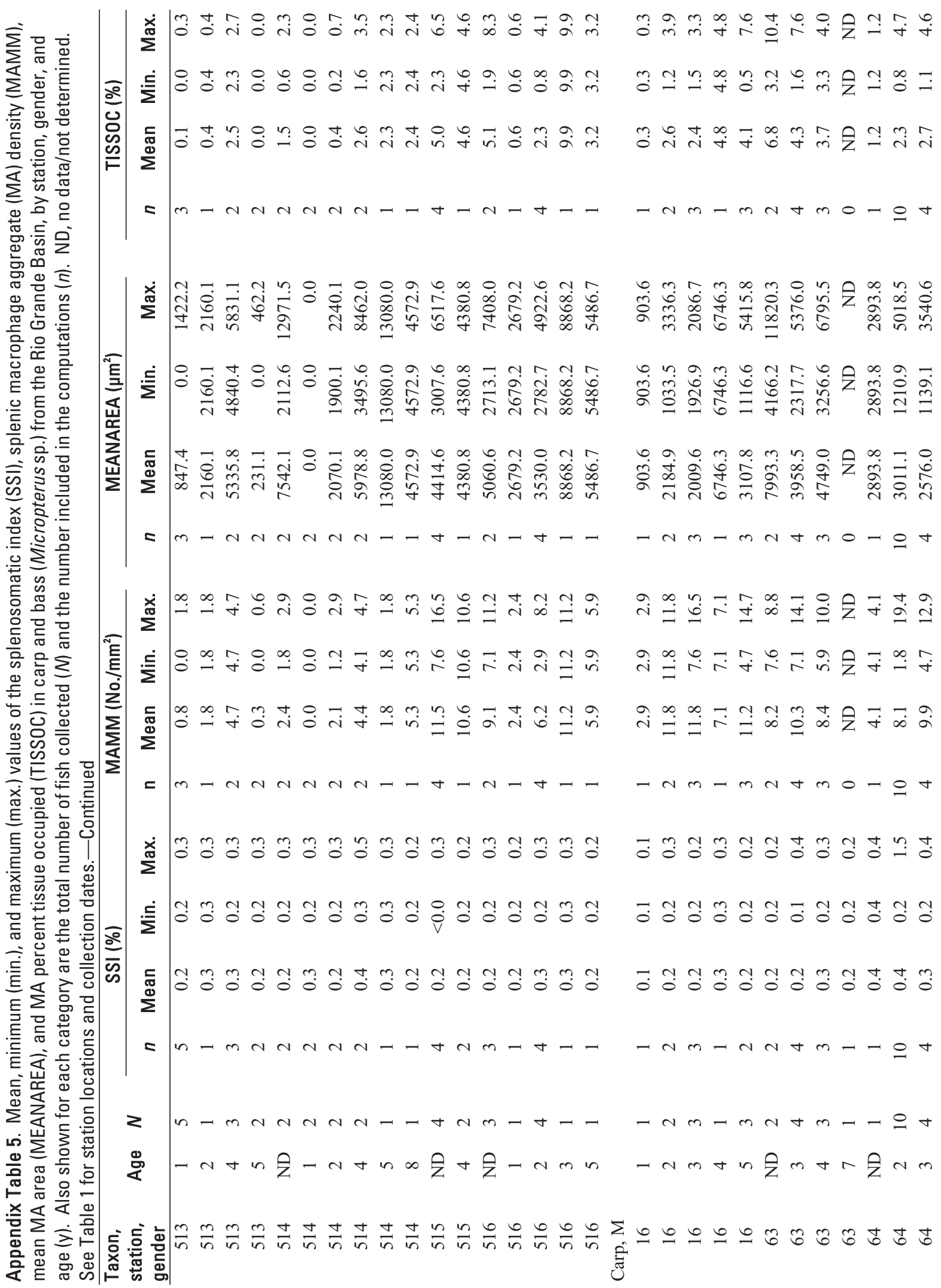




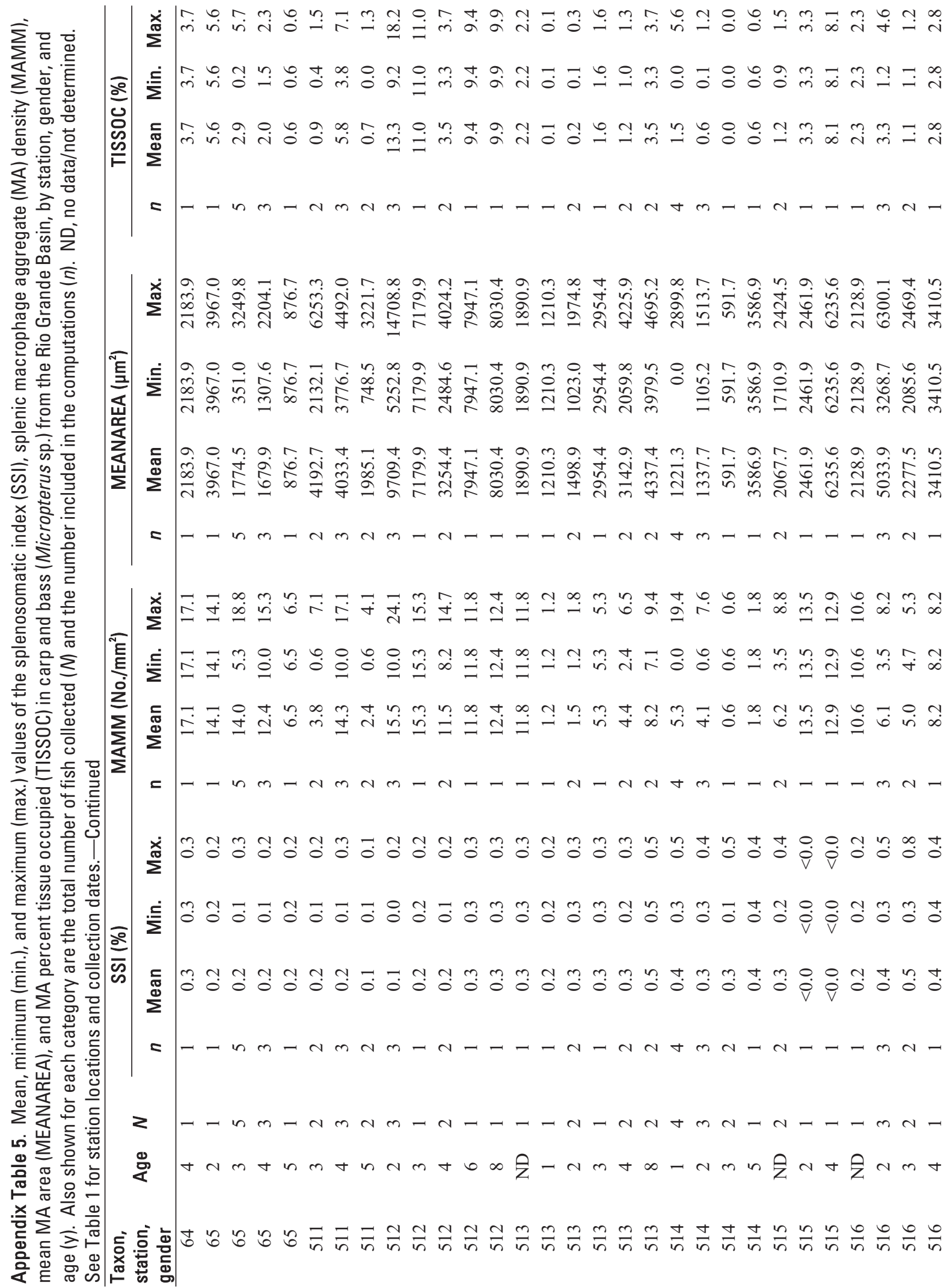




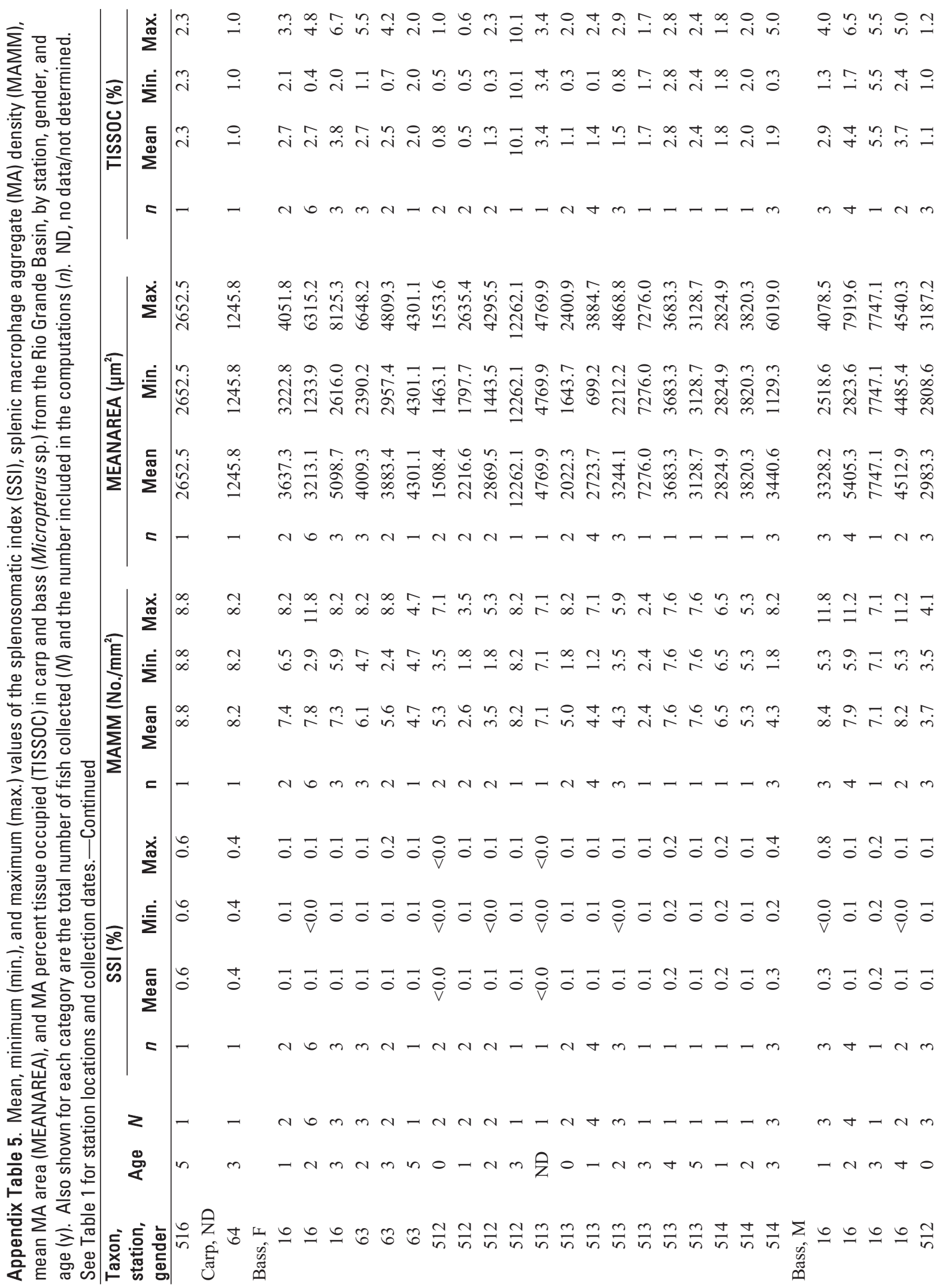




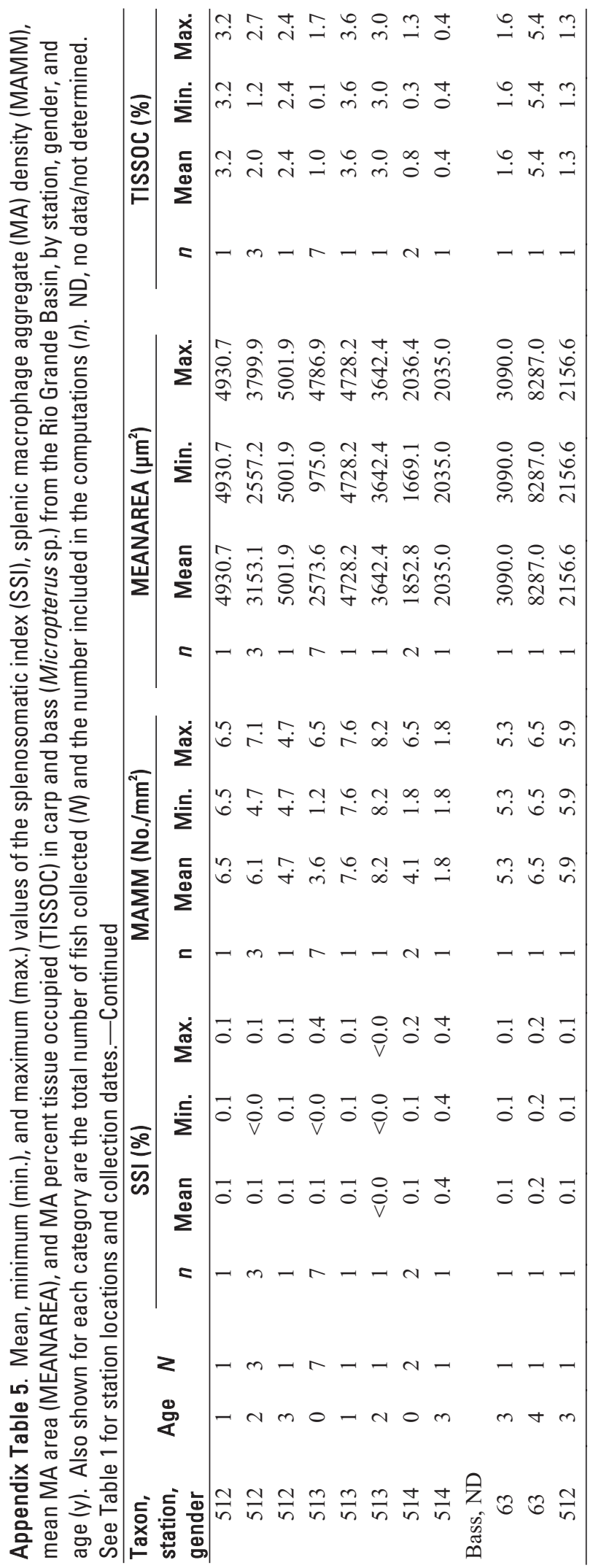




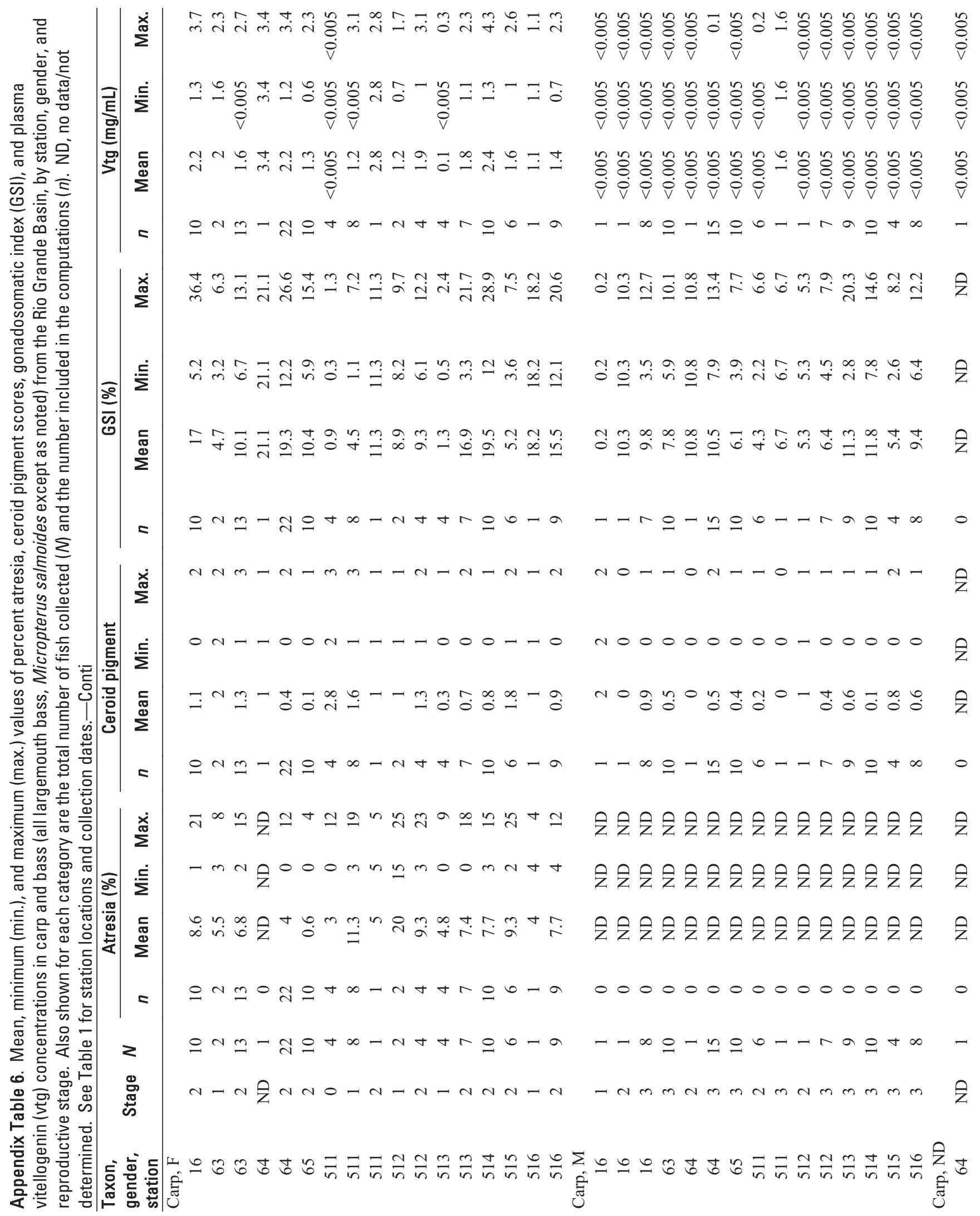




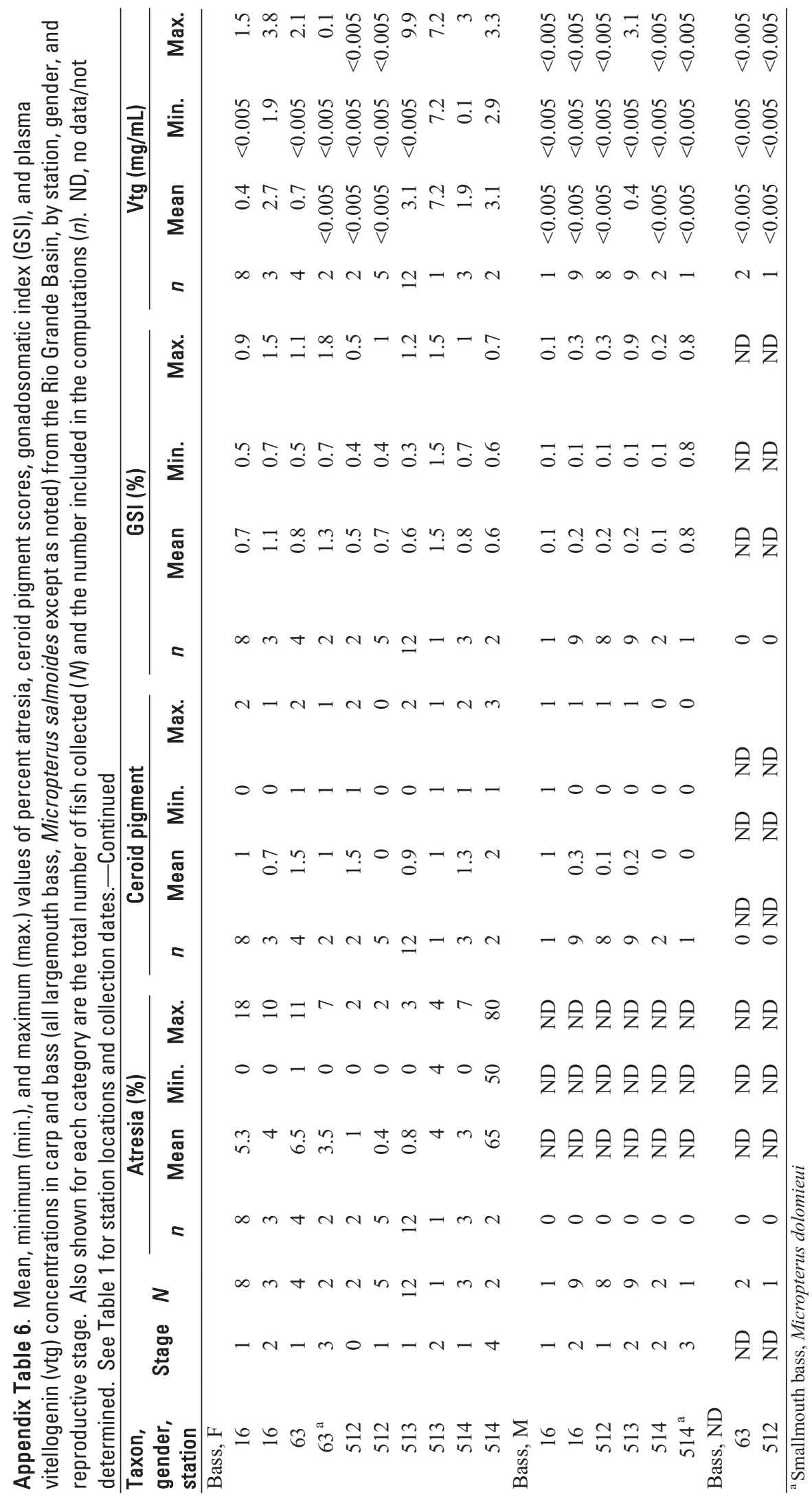


118 Environmental Contaminants and their Effects on Fish 


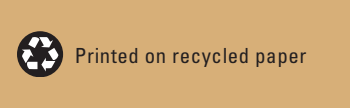

